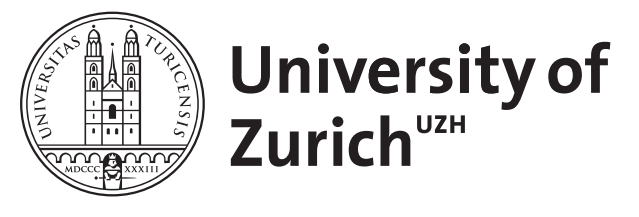

\title{
Kapitalmarkt - Recht und Transaktionen XV
}

Bähler, Marion ; Del Vecchio, Christina ; Favre, Olivier ; Frick, Jürg ; Gerszt, Arie ; Maire, Sonja ; Nikitine, Alex ; Reutter, Thomas U ; Weber, Annette

\begin{abstract}
Der vorliegende Tagungsband «Kapitalmarkt - Recht und Transaktionen» fokussiert wie immer auf aktuelle Entwicklungen im Bereich Finanz- und Kapitalmarktrecht unter besonderer Berücksichtigung von Transaktionen. Das Jahr 2019 war geprägt von einem stark wachsenden Bewusstsein für soziale und ökologische Themen, das auch vor Investoren nicht Halt gemacht hat. Eine wichtige Rolle spielten zudem der sich beschleunigende technologische Fortschritt und das sich anbahnende Ende des LIBOR. Entsprechend liegt der von den Herausgebern gesetzte Schwerpunkt auf Corporate Social Responsibility, der LIBOR-Ablösung und den zivil- und finanzmarktrechtlichen Aspekten der DLT-Vorlage des Bundesrates im Bereich Blockchain. Daneben erhalten auch traditionelle Themen wie Rechtsfragen im Zusammenhang mit Börsengängen und Analyst Reports Raum in diesem Band.
\end{abstract}

DOI: https://doi.org/10.36862/eiz-350

Posted at the Zurich Open Repository and Archive, University of Zurich

ZORA URL: https://doi.org/10.5167/uzh-198879

Edited Scientific Work

Published Version

Originally published at:

Bähler, Marion; Del Vecchio, Christina; Favre, Olivier; Frick, Jürg; Gerszt, Arie; Maire, Sonja; Nikitine, Alex; Reutter, Thomas U; Weber, Annette Kapitalmarkt - Recht und Transaktionen XV. Edited by: Reutter, Thomas U; Werlen, Thomas (2020). Zürich: EIZ Publishing.

DOI: https://doi.org/10.36862/eiz-350 


\section{(i) \\ EuropaInstitut}

AN DER UNIVERSITÄT ZÜRICH

\section{Herausgeber:}

Thomas U. Reutter, Thomas Werlen

\section{Kapitalmarkt -}

Recht und Transaktionen XV 



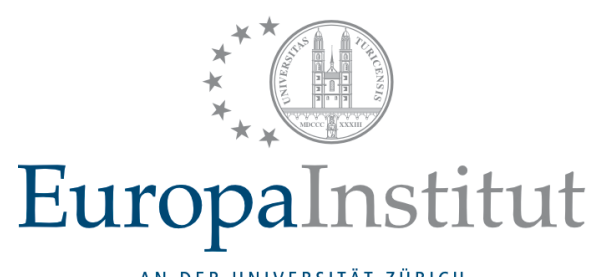

AN DER UNIVERSITÄT ZÜRICH

Herausgeber:

Thomas U. Reutter, Thomas Werlen

Kapitalmarkt -

Recht und Transaktionen XV

EIZ $*_{*+*}^{* *}$ Publishing 


\section{() (1) $\circledast$}

Kapitalmarkt - Recht und Transaktionen XV von Thomas U. Reutter und Thomas Werlen wird unter Creative Commons Namensnennung-Nicht kommerziell-Keine Bearbeitung 4.0 International lizenziert, sofern nichts anderes angegeben ist.

(C) 2020 - CC BY-NC-ND (Werk), CC BY-SA (Text)

Herausgeber: Thomas U. Reutter, Thomas Werlen - Europa Institut an der Universität Zürich

Verlag: EIZ Publishing

Produktion, Satz \& Vertrieb: buch \& netz, buchundnetz.com

Cover: buch \& netz, buchundnetz.com

\section{ISBN:}

978-3-03805-350-7 (Print - Softcover)

978-3-03805-374-3 (PDF)

978-3-03805-375-0 (ePub)

978-3-03805-376-7 (mobi/Kindle)

DOI: https://doi.org/10.36862/eiz-350

Version: 1.01 - 20201203

Dieses Werk ist als buch \& netz Online-Buch und als eBook in verschiedenen Formaten sowie als gedrucktes Buch verfügbar. Weitere Informationen finden Sie unter der URL:

https://buchundnetz.com/werke/kapitalmarkt-recht-und-transaktionen-xv/. 


\section{Vorwort}

Das schweizerische und internationale Kapitalmarktrecht befinden sich in ständigem Wandel. Eine Vielzahl technologischer Entwicklungen, wie zum Beispiel das Aufkommen von Digitalwährungen, stellen nicht nur Marktteilnehmer sondern auch die Rechtspraxis vor erhebliche Herausforderungen. Gleichzeitig tragen national und international vorangetriebene Gesetzesvorhaben zu einem sich verändernden rechtlichem Umfeld bei. Vor diesem Hintergrund beleuchten führende Vertreter aus der Praxis aktuelle Fragestellungen.

Die diesjährige Tagung befasste sich mit einer Reihe von neuen Themenfeldern und regulatorischen Neuerungen. Im Unterschied zu vergangen Jahren wurde kein Fokus auf ein ausgesuchtes Sachgebiet gelegt. Stattdessen wurde zu einer Reihe von Themen referiert, die aufgrund ihrer Aktualität von besonderem Interesse sind. Dazu zählen zum einen Fragestellungen im Zusammenhang mit Corporate Social Responsibility- ein Gebiet welches sich in den letzten Jahren wachsender Aufmerksamkeit erfreut. Zum anderen durften die Teilnehmer einem Referat über die rechtlichen Implikationen der Blockchain Technologie beiwohnen. Auch die Ablösung des LIBOR, in absehbarer Zeit eine Herausforderung für die internationalen Finanzmärkte, wurde behandelt. $\mathrm{Zu}$ aktuellen rechtlichen Veränderungen kamen Vorträge über Themen, die über die Jahre hinweg nicht an Aktualität eingebüsst haben.

ALEX NiKitine widmete sich den Herausforderungen im Zusammenhang mit der Vorbereitung von IPO's. CHRISTINA DEL VECCHIO ging Fragen mit Bezug auf die Verwendung von Pre-Deal Recherche- Berichten nach. OlIVER FAVRE zeigte auf, was die Ablösung des LIBOR für den Derivatemarkt bedeutet. JÜRG FRICK gab einen Überblick über rechtliche Fragestellungen im Zusammenhang mit Intercreditor Verträgen ANETTE WEBER und THOMAS REUTTER referierten über die Implikationen von „Corporate Social Responisbility für den Kapitalmarkt mit besonderem Fokus auf Green Bonds. Abschliessend befassten sich ARIE GERSZT und SONJA MAIRE mit möglichen regulatorischen Änderungsvorschlägen im Blockchain Bereich.

Die Tagung richtete sich wie bereits seit nunmehr fünfzehn Jahren an Rechtsanwälte und Unternehmensjuristen im Bereich Kapital- und Finanzmarktrecht. Der Fokus lag wie bis anhin auf der Vermittlung von praktischem Knowhow. Mit dem diesem Tagungsband hoffen die Herausgeber, die thematisch vielfältigen Beiträge aus dem schweizerischen Kapitalmarktrecht einem breiterem Publikum zugänglich zu machen. 
Für das gute Gelingen der Tagung und der Veröffentlichung dieses Bandes möchten wir herzlich danken: den Referenten und Verfassern von Beiträgen, Frau Tiziana Rigamonti-Ammann für die Durchführung der Veranstaltung sowie Noura Ranja Mourad und Sue Osterwalder für die Gestaltung dieses Tagungsbandes.

Zürich, im August 2020

Thomas U. Reutter/Thomas Werlen 


\section{Inhaltsübersicht}

IPO Readiness - Stolpersteine auf dem Weg zum Börsen-

\section{gang}

Dr. AleX NiKITINE, Rechtsanwalt, LL.M., Partner bei Walder

Wyss AG, Zürich

MARION BÄHLER, Rechtsanwältin, LL.M., Managing Associate

bei Walder Wyss AG, Zürich

Pre-Deal Research Reports in Initial Public Offerings: An

\section{Internationally Diverse Approach}

Christina DEL VeCCHIO, Counsel, J.D., Niederer Kraft Frey AG, Zürich

\section{LIBOR Transition for Derivatives Transactions}

Dr. OLIVIER FAVRE, LL.M., Partner bei Schellenberg Wittmer AG, Zürich

CSR und Kapitalmarkt

ANNETTE WeBER, Rechtsanwältin, LL.M., Partnerin bei

Advestra AG, Zürich

Dr. THOMAS U. REUTTER, Rechtsanwalt, LL.M., Partner bei Advestra AG, Zürich

DLT-Vorlage des Bundesrates: Zivil- und finanzmarkt-

\section{rechtliche Aspekte}

Dr. SONJA MAIRE, Bundesamt für Justiz, Fachbereich Zivilrecht und Zivilprozessrecht, Bern

ARIE GERSZT, Rechtsanwalt, LL.M., Staatssekretariat für internationale Finanzfragen, Leiter Sektion Kapitalmärkte und Infrastruktur, Bern 



\title{
IPO Readiness - Stolpersteine auf dem Weg zum Börsengang
}

\author{
Alex Nikitine/Marion Bähler
}

\section{Inhalt}

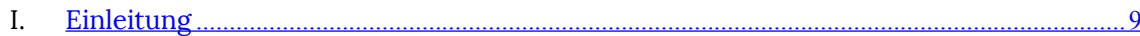

II. Wichtigste Grundvoraussetzungen für ein IPO ………………………………………....... 11

1. Erfüllung der Mindestanforderungen für die Kotierung .......................................... 11

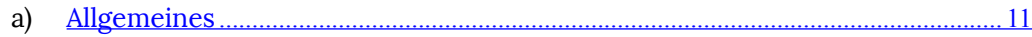

b) Mindestkennzahlen ........................................................................................ 12

c) Rechnungslegung und Revisionsorgane .......................................................... 14

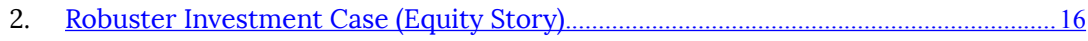

3. Starke Corporate Governance sowie sinnvolle Struktur und Organisation ................ 18

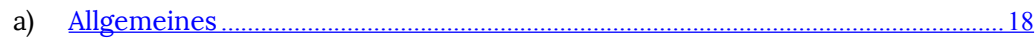

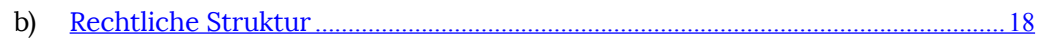

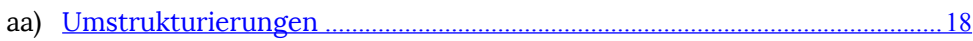

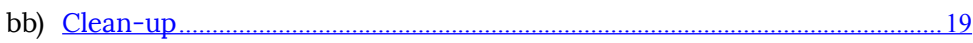

c) Corporate Governance und regulatorische Vorgaben .......................................... 19

d) Organisation der Führungsebene …………………………………….....................22

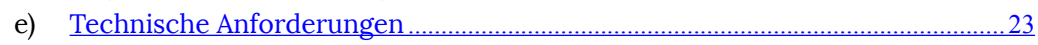

4. Überwindung bestimmter praktischer Hindernisse ......................................................23

a) Pläne der aktuellen Eigentümer ………………………………..............................23

b) Abschreckung vor hoher Transparenz …………..................................................2

c) Respekt vor hohen Kosten ..................................................................................26

d) Vertragliche Schranken ....................................................................................27

\section{Einleitung}

In den letzten Jahren hat die SIX Swiss Exchange mit Sitz in Zürich, die grösste und bekannteste Schweizer Börse, etliche Neuzugänge verzeichnet. In den Jahren 2019 und 2020 haben neun Unternehmen den Schritt auf das Börsenparkett gewagt, im Jahr 2018 waren es sogar zwölf. ${ }^{1}$ Man darf durchaus davon ausgehen, dass noch das eine oder andere Projekt in der Pipeline steht und die Schweizer Börsen in den nächsten Jahren noch zahlreiche Neuzu-

1 Vgl. die Übersicht unter < $\underline{\text { https://www.six-group.com/de/products-services/the-swiss- }}$ stock-exchange/market-data/shares/ipo-history.html>. 
gänge verzeichnen dürfen, auch wenn die im Frühjahr 2020 ausgebrochene COVID-19-Pandemie einige dieser Pläne (einstweilen) durchkreuzt haben dürfte. ${ }^{2}$

Auch das vitale Venture Capital-Segment könnte seinen Beitrag zu Schweizer Börsengängen leisten und vielversprechende Kandidaten hervorbringen: Alleine im Jahr 2019 wurden fast CHF 2,3 Mrd. in Schweizer Start-ups und jüngere Unternehmen investiert, was einer Zunahme von über $85 \%$ gegenüber dem Vorjahr entspricht. Dabei ist besonders hervorzuheben, dass auch mehrere Finanzierungsrunden mit einer Investitionssumme von mehr als CHF 100 Mio. durchgeführt worden sind. Es gibt sogar mehrere Schweizer (Jung-)Unternehmen, welche in die illustre Gruppe der „unicorns“ (Unternehmen, deren Bewertung CHF 1 Mrd. oder mehr beträgt) aufgenommen wurden. ${ }^{3}$

Es gibt zahlreiche Gründe, weshalb sich ein Unternehmen bzw. deren Eigner für einen Börsengang bzw. ein sog. initial public offering („IPO“) ${ }^{4}$ entscheiden. In den meisten Fällen stehen Kapitalbeschaffungsmotive im Vordergrund, denn die Beschaffung von substantiellen Eigenmitteln ist bei Publikumsgesellschaften in der Regel als Folge des Zugangs zum Kapitalmarkt einfacher als bei privat gehaltenen Unternehmen. Häufig werden IPOs jedoch auch im Zusammenhang mit einem geplanten, allenfalls gestaffelten Ausstieg von Aktionären (Nachfolgeregelung) bzw. mit einer anderen beabsichtigten Änderung der Beteiligungsstruktur ins Auge gefasst. Hinzu kommen publizitätsbezogene Motive, geht ein IPO doch in der Regel Hand in Hand mit einer Steigerung der Bekanntheit und der Attraktivität als Arbeitgeber der entsprechenden Gesellschaft, was auch die Rekrutierung gesuchter Spitzenkräfte erleichtern kann.

2 Durchgezogen wurden hingegen die Ausgliederung und Kotierung des Geschäftsbereichs Haushaltapparate (V-Zug) aus der Metall Zug AG sowie die Ausgliederung und Kotierung des Immobiliensektors der Implenia AG, Ina Invest Holding AG.

3 Vgl. zum Ganzen: startupticker.ch; At a glance - Investment hits a new high; Swiss Venture Capital Report 2020 (Edition No 8), 7 (abrufbar unter <https://www.startupticker.ch/ uploads/VCReport 2020 web.pdf $>$ ). Die Bewertungen sind als Folge der COVID-19-Pandemie indes mit äusserster Zurückhaltung zu geniessen. Viele dieser Unternehmen dürften im Jahr 2020 kaum mehr an diese (ohnehin schon sehr hohen) Bewertungen herankommen.

4 Als „Börsengang“ wird typischerweise eine Kotierung der Aktien an einer Börse bezeichnet, wobei in diesem Zusammenhang oftmals neue oder bestehende Aktien öffentlich emittiert werden (daher „initial public offering“). In der Vergangenheit gab es auch mehrere Börsengänge, in deren Rahmen keine Aktien ausgegeben wurden (sog. „direct listing“, z.B. WISeKey International Holding AG), wobei Letzteres auch bei Ausgliederungen („spin-offs“) gewöhnlich der Fall ist (z.B. die Idorsia AG aus der Actelion AG und die Alcon AG aus der Novartis Holding AG). 
Ungeachtet ihres (Haupt-)Motivs geht allen IPOs ein über mehrere Monate dauernder, komplexer Prozess hervor, der sich grundsätzlich in eine Vorbereitungsphase (umfassend sowohl den Zeitraum vor und nach dem „kick-off“ des IPO), in eine Vermarktungs- und Durchführungsphase sowie in eine Nachbereitungsphase unterteilen lässt. Die Vorbereitungsphase dient der Vorbereitung des Unternehmens auf das IPO, während die Vermarktungs- und Durchführungsphase mit einem Kundtun der IPO-Absichten (,intention to float") und der konkreten Suche nach Investoren beginnt und mit einer Preisfestlegung sowie dem Handelsstart endet. In der Nachbereitungsphase werden weitere, mit dem IPO zusammenhängende Aufgaben in Angriff genommen, wie beispielsweise Stabilisierungsprozesse, die Kommunikation mit den Medien, den Investoren sowie Analysten oder die Durchführung von Folgetransaktionen. $^{5}$

In vielen Fällen „sterben“ IPO-Unterfangen jedoch bereits in der Vorbereitungsphase, also noch vor der eigentlichen offiziellen Lancierung eines solchen Projekts. Man spricht in diesem Kontext bzw. in dieser Vorphase von der Evaluation der „IPO-Readiness“. Die Beteiligten (meist Entscheidungsträger auf Seiten der Hauptaktionäre sowie der Verwaltungsrat, evtl. unter Beizug von ausgewählten Mitgliedern des Management) kommen im Rahmen dieser ersten Evaluation zusammen mit den Beratern zum Schluss, dass das Unternehmen als solches (oder dessen Eigner) nicht oder noch nicht "ready" sind für einen Börsengang. Die Gründe, den Gang an die Börse vorerst auf Eis zu legen, dürften nicht selten darin liegen, dass die Konsequenzen und die Komplexität eines Börsengangs verkannt und/oder unterschätzt werden. Der vorliegende Beitrag identifiziert und beleuchtet ausgewählte Stolpersteine im Zusammenhang mit der Vorbereitung eines Börsengangs.

\section{Wichtigste Grundvoraussetzungen für ein IPO}

I. Erfüllung der Mindestanforderungen für die Kotierung

\section{a) Allgemeines}

Jede anerkannte Börse regelt die Voraussetzungen für die Kotierung von Wertpapieren auf ihrem Handelsplatz. Es versteht sich von selbst, dass der

5 Vgl. hierzu u.a. SIX Swiss Exchange, Gestalten Sie Ihr IPO zielgerichtet und effizient, IPO Guide der Schweizer Börse (April 2020), 18 ff. (abrufbar unter <https://www.sixgroup.com/dam/download/the-swiss-stock-exchange/listing/equity/ipo/ six ipo guide de.pdf $>$; nachfolgend „IPO-Guide“). 
Börsengang einer Gesellschaft überhaupt nur in Betracht gezogen werden kann, wenn die entsprechenden formellen Vorgaben der ins Auge gefassten Börse erfüllt sind. Die SIX Swiss Exchange regelt die für sie geltenden Vorgaben in einem Kotierungsreglement, das regelmässig angepasst und durch Rundschreiben erläutert wird. Das Gleiche gilt für die zweite vollwertige Börse in der Schweiz, die BX Swiss AG. ${ }^{6}$

\section{b) Mindestkennzahlen}

Die Bestimmungen des Kotierungsreglements der SIX Swiss Exchange sehen insbesondere vor, dass das ausgewiesene (konsolidierte) Eigenkapital der Emittentin mindestens CHF 2,5 Mio. betragen muss. ${ }^{7}$ Jener Betrag muss am ersten Handelstag vorliegen, weshalb der (Nominal-)Betrag einer allfälligen im Rahmen des IPO durchgeführten Kapitalerhöhung hinzugerechnet wird. Nicht zu berücksichtigen ist hingegen ein allfälliges Agio, welches typischerweise erst bei der Abrechnung des Erlöses zwischen der Emittentin und den Underwriting-Banken, mithin ein paar Tage nach Handelsbeginn zur Verfügung steht. ${ }^{8}$

Ferner ist vorgeschrieben, dass im Zeitpunkt der Kotierung eine ausreichende Streuung der Effekten bestehen muss. Eine solche gilt als erreicht, wenn die in der gleichen Kategorie ausstehenden Effekten des Emittenten zu mindestens 20\% im Publikumsbesitz sind und die Kapitalisierung der sich im Publikumsbesitz befindenden Effekten (sog. ,free float") mindestens CHF 25 Mio. beträgt. ${ }^{9}$

${ }^{6}$ Der Einfachheit halber wird in diesem Beitrag lediglich auf die Regularien der SIX Swiss Exchange eingegangen. Im Rahmen eines beabsichtigten Börsengangs an der BX Swiss AG dürften insbesondere das Kotierungsreglement der BX Swiss AG (20. November 2020), die Liste der für Kotierungen an der BX Swiss generell anerkannten Rechnungslegungsstandards gem. Art. 51 Abs. 3 der Finanzdienstleistungsverordnung (1. Februar 2020), die Richtlinie Track Record (20. November 2020) sowie die Übersicht der Regelmeldepflichten primärkotierter Emittenten (1. Mai 2018) bzw. doppelkotierter Emittenten (1. Mai 2018) von besonderer Relevanz sein.

7 Art. 15 des Kotierungsreglements der SIX Exchange Regulation AG vom 8. November 2019 (nachfolgend „KR").

8 Vgl. hierzu Giger MARCEL in: The SIX Swiss Exchange Listing Rules, SHK - Stämpflis Handkommentar, Art. 15, N 4.

9 Art. 19 KR. 
Dabei bestimmt sich die Kapitalisierung der sich im Publikumsbesitz befindenden Beteiligungsrechte nach dem für die Eröffnung des Handels am ersten Handelstag angegebenen theoretischen Eröffnungspreis der Emittentin. ${ }^{10}$

Mit diesen Vorgaben zur Streuung und zur Kapitalisierung bezweckt die SIX Swiss Exchange das „Zustandekommen eines marktmässigen Handels“.11 In der Regel dürfte das Erreichen dieser Zielgrössen Gesellschaften, die ein IPO ins Auge fassen, keine Schwierigkeiten bereiten. Die Praxis hat jedoch gezeigt, dass für die effektive Kapitalmarktfähigkeit wohl erheblich höhere Anforderungen gelten. So beträgt beispielsweise die durchschnittliche Marktkapitalisierung der Unternehmen, die seit Beginn des Jahres 2010 an der SIX Swiss Exchange kotiert wurden, rund CHF 2,37 Mrd. und der Median immerhin ebenfalls noch rund CHF 525,7 Mio. Lediglich drei von insgesamt 52 Unternehmen wiesen zum Zeitpunkt des ersten Schlusskurses eine Marktkapitalisierung von unter CHF 100 Mio. auf. ${ }^{12}$ Auch die mit der Begleitung von IPOs beauftragten Investmentbanken äussern sich oft dahingehend, dass der free float bei einer tiefen Marktkapitalisierung mindestens CHF 50-100 Mio. betragen sollte (und dieser Anteil mind. ein Drittel der Marktkapitalisierung ausmachen sollte). Vielfach dürften IPO-Projekte daher bereits an einer (noch) zu tiefen Bewertung des Unternehmens scheitern.

10 Art. 5 der Richtlinie betr. Streuung von Beteiligungsrechten (nachfolgend „RL Streuung“). Vgl. in diesem Zusammenhang auch Art. 4 RL Streuung: Nicht zum Publikumsbesitz werden dabei gerechnet: Beteiligungsrechte, die von der Emittentin selbst oder einer ihrer Tochtergesellschaften gehalten werden; Beteiligungsrechte von Aktionären oder verbundenen Aktionärsgruppen von mehr als fünf Prozent im Sinne von Art. 120 ff. des Bundesgesetzes über die Finanzmarktinfrastrukturen und das Marktverhalten im Effekten- und Derivatehandel vom 19. Juni 2015 (nachfolgend „FinfraG“) gehalten werden; Beteiligungsrechte, die zur Sicherstellung von Wandel- oder Optionsrechten dienen (soweit sie nicht bereits als Beteiligungsrechte der Emittentin gelten); Beteiligungsrechte, welche im Rahmen von Lock-up-Vereinbarungen nicht frei handelbar sind; und Beteiligungsrechte, deren Platzierung von Bedingungen abhängig ist (z.B. Mehrzuteilungs-Option).

11 Art. 2 RL Streuung.

12 Vgl. Übersicht unter <https://www.six-group.com/de/products-services/the-swissstock-exchange/market-data/shares/ipo-history.html>. Berücksichtigt wurden Börsengänge bis 30. November 2020. Im Falle der Angabe der Marktkapitalisierung in einer Fremdwährung, wurde der Interbankenwechselkurs vom 30. November 2020 zur Berechnung verwendet. 
Die weitere Voraussetzung, wonach die Emittentin mindestens drei Jahres als Gesellschaft bestanden haben muss, dürfte hingegen kaum jemals ein Hindernis darstellen (im Übrigen gäbe es Ausnahmeregelungen für junge Gesellschaften). ${ }^{13}$

c) Rechnungslegung und Revisionsorgane

Das Kotierungsreglement der SIX Swiss Exchange schreibt ferner vor, dass Emittenten von Beteiligungsrechten grundsätzlich entweder IFRS, US GAAP, Swiss GAAP oder den bankengesetzlichen Rechnungslegungsstandard anwenden müssen. ${ }^{14}$ Häufig führen Schweizer Gesellschaften ihre Bücher jedoch nach den Rechnungslegungsbestimmungen des schweizerischen Obligationenrechts oder einem anderen von der SIX Swiss Exchange nicht anerkannten Rechnungslegungsstandard. Dem Schritt an die Börse geht daher nicht selten eine Umstellung des anzuwendenden Rechnungslegungsstandards voraus. Ein solcher Wechsel kann mit einem erheblichen Aufwand verbunden sein, insbesondere wenn in den vorherigen Jahren die für die Erstellung benötigten Zahlen nicht, nicht umfassend oder sogar falsch ermittelt bzw. geprüft worden sind und daher vorab ein komplexer und langwieriger Aufarbeitungsprozess notwendig ist.

In zeitlicher Hinsicht zu beachten ist zudem auch, dass das Kotierungsreglement vorschreibt, dass die Emittentin ihre Jahresabschlüsse für die drei dem Kotierungsgesuch vorangegangenen vollen Geschäftsjahre entsprechend dem anwendbaren Rechnungslegungsstandard erstellt haben muss. ${ }^{15}$ Potentielle Emittenten müssen daher - wiederum Ausnahmen vorbehalten - über diesen „track record“ verfügen. Ist Letzteres nicht erfüllt, müssen jene Jahresabschlüsse nochmals im Einklang mit den relevanten Rechnungslegungsstandards erstellt werden.

$\mathrm{Zu}$ berücksichtigen sind in diesem Zusammenhang auch die verschärften Anforderungen bei Vorliegen wesentlicher Strukturveränderungen. Demnach müssen im Kotierungsprospekt zusätzliche Finanzzahlen veröffentlicht werden, wenn die Struktur einer Emittentin eine wesentliche Änderung erfahren

13 Art. 11 KR. Diese Ausnahmebestimmung wurde in den letzten Jahren nie in Anspruch genommen.

14 Art. 6 der Richtlinie betr. Rechnungslegung der SIX Exchange Regulation AG vom 11. September 2019 (nachfolgend „RL Rechnungslegung“), vgl. ferner auch Art. 51 der Verordung über die Finanzdienstleistungen vom 9. November 2019 i.V.m. Art. 40 Abs. 1 Bst. a Ziff. 2 des Bundesgesetzes über die Finanzdienstleistungen vom 15. Juni 2018 (nachfolgend „FIDLEG“). Art. $12 \mathrm{KR}$. 
hat, die nicht in einem geprüften Abschluss dargestellt ist. ${ }^{16}$ Wann eine solche wesentliche Strukturveränderung vorliegt, ergibt sich auf Grundlage einer Veränderung von mehr als $25 \%$ bestimmter Kennzahlen (u.a. von Ertrag, Umsatz und Bilanzsumme), die nach bestimmten vorgegebenen Formeln zu berechnen sind.$^{17}$ Als Strukturveränderungen gelten dabei insbesondere:

- eine wirtschaftliche Fortführung eines bereits bestehenden Unternehmens oder von Unternehmensteilen in einer neuen Struktur;

- eine Fusion sowie Akquisition unter Verwendung des Erlöses aus der vorliegenden Kapitalmarkttransaktion oder durch Sacheinlage;

- eine Abspaltung von Unternehmen oder Unternehmensteilen; oder

- wenn sich die Emittentin aus Gesellschaften zusammensetzt, die unter einheitlicher Leistung standen, aber in der Vergangenheit nie konsolidierte Zahlen erstellt haben. ${ }^{18}$

Die Finanzabschüsse sind von einem staatlich beaufsichtigten Revisionsunternehmen zu prüfen. ${ }^{19}$ Unter Umständen geht ein IPO-Projekt daher auch mit einem Wechsel der Revisionsstelle einher (vielfach hin zu grösseren und bekannteren Revisionsgesellschaften, welche sich mit der Prüfung von Publikumsgesellschaften auskennen).

Der im Zusammenhang mit den Finanzabschlüssen notwendige Vorbereitungsaufwand von potentiellen neuen Emittenten und dessen Dauer dürfen keinesfalls unterschätzt werden. Gesellschaften, die kurz- oder mittelfristig an einem IPO interessiert sind, tun daher gut daran, frühzeitig interne Prozesse und Abläufe zu prüfen und gegebenenfalls anzupassen und mit der Revisionsstelle Kontakt aufzunehmen bzw. eine Revisionsstelle zu engagieren, die die gesetzlichen und regulatorischen Vorgaben erfüllt. Die Revisionsstelle sollte sodann bereits zu Beginn in das Projekt einbezogen werden. Dies umso mehr, falls im Zusammenhang mit dem IPO oder in dessen Vorfeld Umstrukturierungen geplant sind (beispielsweise die Reorganisation zum Zwecke der Gründung einer neuen Holding-Gesellschaft, deren Aktien kotiert werden sollen).

16 Art. 4 der Richtlinie betr. Darstellung von komplexen finanziellen Verhältnissen im Kotierungsprospekt der Swiss Exchange Regulation vom 2. März 2016 (nachfolgend „RL komplexe finanzielle Verhältnisse“).

17 Art. 5, 17 und 18 RL komplexe finanzielle Verhältnisse.

18 Art. 5 RL komplexe finanzielle Verhältnisse.

19 Art. 12 ff. KR, vgl. ferner Art. 7 und Art. 8 des Bundesgesetzes über die Zulassung und Beaufsichtigung der Revisorinnen und Revisoren vom 16. Dezember 2005. 


\section{Robuster Investment Case (Equity Story)}

Ein robuster und attraktiver Investment Case ist zentral für das Gelingen eines IPO. Bei jenem handelt es sich im Wesentlichen um eine Zusammenstellung und Erläuterung derjenigen Attribute, welche die Investoren dazu bewegen sollen, im Rahmen des Börsengangs in das konkrete Unternehmen zu investieren. Er dient dazu, das Interesse und die Begeisterung potentieller Investoren zu wecken, indem dargelegt wird, weshalb Investoren gerade in dieses und nicht in ein anderes Unternehmen investieren sollen. Der Investment Case wird die Gesellschaft durch den ganzen Prozess eines IPO begleiten und sollte daher klare, positive und wahrheitsgetreue Aussagen reflektieren. Dabei sollten sich die im Investment Case eingearbeiteten Aussagen auf eine klare Unternehmensstrategie und einen überzeugenden Business Plan abstützen können. Die Erstellung des Investment Cases bietet den obersten Leitungsorganen gleichzeitig eine ideale Gelegenheit, die eigene Wahrnehmung mit den tatsächlichen Gegebenheiten abzugleichen und Bestehendes kritisch zu hinterfragen. Nicht selten wird im Zuge eines IPO-Projekts eine Unternehmensstrategie etwas angepasst, um den Investment Case für potentielle Investoren interessanter zu machen. Im Rahmen solcher Anpassungen kommt es gelegentlich auch vor, dass die Unternehmensstrategie enger bzw. fokussierter definiert wird.

Folgende Themenbereiche dürften in der Regel bei der Erarbeitung eines Investment Cases berücksichtigt werden: ${ }^{20}$

- Strategie

- Verfolgt man eine Wachstums- oder eine Renditestrategie?

- Möchte man sich in einem Nischenmarkt positionieren oder skalieren?

- Industrie

- Was sind die Entwicklungen/Trends?

- Wie beständig bzw. dynamisch ist die Industrie?

- Produkt

- Verfügt man über eine besondere Technologie oder ein besonderes Produkt?

20 Vgl. hierzu auch WÜEST DANIEL, Investment Case, in: Going Public on SIX Swiss Exchange, 2nd Edition 2015, 50 (abrufbar unter <https://www.six-group.com/dam/download/theswiss-stock-exchange/listing/equity/ipo/publication.pdf >; nachfolgend „Going PublicGuide"). 
- Hat man Wettbewerbsvorteile (z.B. „first mover-advantage“, günstigster Anbieter)?

- Markt

- Was ist das Markt- bzw. das Wachstumspotential?

- Welche Markthindernisse gibt es?

- Welchen Marktanteil strebt man an?

- Auf welches Gebiet möchte man sich konzentrieren?

- Mitstreiter

- Wer sind die Hauptmitstreiter?

- Gibt es möglich Synergien?

- Verwaltungsrat/Geschäftsführer

- Wie setzen sich die obersten Leitungsorgane zusammen?

- Gibt es nennenswerte Neuzugänge im Zusammenhang mit dem IPO?

- Über welche Erfahrung verfügen die Mitglieder des obersten Leitungsorganes?

- Was waren die grössten Erfolge in der Vergangenheit?

Die einzelnen Komponenten sind in sinnvoller Weise miteinander zu verflechten, auf die Gesellschaft abzustimmen und ansprechend zu präsentieren.

In der Praxis kristallisieren sich bei den Investment Cases der IPO-Kandidaten primär zwei Grundkategorien heraus: Einerseits solche, die ein „DividendenModell" vermarkten und anderseits solche, die auf das "Wachstums-Modell" fokussieren. Wie die Bezeichnung unschwer erkennen lässt, handelt es sich beim "Dividenden-Modell“ meistens um den Investment Case etablierter Unternehmen, die in der Vergangenheit bereits attraktive Dividenden ausbezahlt haben und dies idealerweise auch für die Zeit nach dem Börsengang in Aussicht stellen können. Die Attraktivität für potentielle Investoren liegt in diesem Fall daher primär in einer möglichen hohen Dividendenrendite. ${ }^{21}$ Beim „Wachstums-Modell“ dürfen die Investoren hingegen primär auf eine positive Kursentwicklung und eine dadurch erzielte Wertsteigerung hoffen, beispielsweise weil die Gesellschaft im Prozess ist, ein Produkt zu entwickeln, bei welchem eine hohe Nachfrage erwartet wird. Häufig lässt sich der Investment

21 Als Beispiel lassen sich die „Privatisierung“ verschiedener Kantonalbanken (zuletzt die Glarner Kantonalbank und die Thurgauer Kantonalbank) aufführen; bei den vorgenannten Emittenten liegt die Dividendenrendite bei über 3\% (Durchschnitt der letzten fünf Jahre). 
Case eines Unternehmens jedoch nicht einer einzigen Kategorie zuordnen, zumal er auch Elemente der jeweils anderen Kategorie enthält und es gewisse Überschneidungen gibt.

Der Erfolg oder das Scheitern eines IPO-Projekts steht und fällt mit dem Investment Case und hängt erheblich von dessen Qualität und Überzeugungskraft ab. Entsprechend sorgfältig sollten die obersten Leitungsorgane bei seiner Erarbeitung vorgehen. Üblicherweise dürfte es zudem angezeigt sein, bereits in diesem Stadium erfahrene Berater beizuziehen, die die Unternehmensführung bei der Erarbeitung des Investment Cases zielführend unterstützen. Im Vordergrund dürfte dabei, insbesondere auch im Hinblick auf eine spätere Vermarktung des Investment Cases, der Beizug einer auf den Finanzmarkt spezialisierten PR-Agentur stehen.

\section{Starke Corporate Governance sowie sinnvolle Struktur und Organisation}

\section{a) Allgemeines}

Ohne eine professionelle organisatorische Struktur, welche in eine zeitgemässe Corporate Governance eingebettet ist, dürfte der Börsengang und das Fortbestehen an der Börse eines Unternehmens zum Scheitern verurteilt sein. IPO-Kandidaten sollten daher darum besorgt sein, bereits in der Vorbereitungsphase die entsprechenden Strukturen zu schaffen. Ein besonderes Augenmerk ist dabei auf die nachfolgenden Teilbereiche zu richten:

\section{b) Rechtliche Struktur}

\section{aa) Umstrukturierungen}

Selbstredend sollte frühzeitig Klarheit darüber bestehen, welche Gesellschaft zu kotieren sei und welche Gesellschaften von der IPO-Gruppe ausgenommen werden sollen. Im Falle mehrerer Gruppengesellschaften ist es angezeigt bereits früh zu prüfen, inwieweit eine Reorganisation notwendig oder sinnvoll erscheint. Dabei dürften primär operative, steuerliche und risikobezogene Überlegungen im Vordergrund stehen. Die Investoren bevorzugen grundsätzlich klare und einfache Verhältnisse, was bei der Planung des IPO ebenfalls berücksichtigt werden sollte. Vielfach wird die Gruppenstruktur so angepasst, dass nicht die Aktien des operativen Unternehmens kotiert werden, sondern 
jene einer neu zu gründenden Holdinggesellschaft. ${ }^{22}$ Falls sich Umstrukturierungen oder Reorganisationen aufdrängen, so müssen dafür genügend Zeit und Ressourcen eingeplant werden.

\section{bb) Clean-up}

In der Praxis muss man leider oft feststellen, dass die Gesellschaft in der Vergangenheit gewissen rechtlichen Aspekten nicht genügend Beachtung geschenkt hat und daher in dieser Hinsicht gewisse Mängel vorliegen. Es handelt sich dabei um Problemfelder, die typischerweise im Rahmen einer klassischen rechtlichen Due Diligence in Erscheinung treten. So bemerkt man beispielsweise, dass die Eigentumsverhältnisse betreffend wichtige Vermögenswerte der Gesellschaft (wie Patente oder Lizenzrechte), unklar sind, weil zu Beginn nicht eine klare Abgrenzung vorgenommen wurde bzw. schon früher vorhandene Rechte nicht auf die Gesellschaft übertragen worden sind. Auch können die Gesellschaften oft nicht eine ununterbrochene „chain-of title“, mithin eine lückenlose Übertragungskette, betreffend ihre eigenen Anteile oder derjenigen allfälliger Tochtergesellschaften nachweisen. Erfahrungsgemäss lassen sich solche Probleme aber oft mit einem gewissen Aufwand beheben. Da aber auch hierfür genügend Zeit und Ressourcen eingeplant werden müssen, sollte man sich ihrer nach Möglichkeit bereits vor dem eigentlichen kick-off des IPO annehmen. In der Praxis tauchen diese Probleme leider oftmals erst in einer gründlichen Due Diligence nach der offiziellen Lancierung des Projekts auf.

\section{c) Corporate Governance und regulatorische Vorgaben}

Für börsenkotierte Unternehmen gelten in Bezug auf die Corporate Governance und interne Kontrollen deutlich höhere Anforderungen als für privat gehaltene Unternehmen. Mit Corporate Governance sind sämtliche Grundsätze, Bestimmungen und Verfahren gemeint, nach denen ein Unternehmen geführt und betrieben werden soll. ${ }^{23}$ Hauptzweck ist die Schaffung funktionie-

22 Vgl. zum Ganzen Frey Martin, IPO Readiness Check, in: Going Public-Guide (vgl. Fn. 20), 26 f., 27. Die Gründe für die Wahl einer Holdingstruktur sind mittlerweile nicht mehr überwiegend steuerlicher Natur (Stichwort: Abschaffung des Holdingprivilegs), sondern operationell (bspw. bewusste Trennung bestimmter Divisionen, um einen späteren (separaten) Verkauf zu vereinfachen, wobei die Trennung auch geographisch bedingt sein kann).

23 Swiss code of best practice for corporate governance (Deutsche Fassung; 2016), 6 (abrufbar unter

$<$ https://www.economiesuisse.ch/sites/default/files/publications/economiesuisse swisscode_d_web.pdf>; nachfolgend „SCBP“). 
render Kontrollsysteme (checks and balances), klarer Kompetenzregelungen, Vorgaben zum Umgang mit Risiken, vereinfachte Entscheidprozesse sowie Transparenz. Gute Corporate Governance-Abläufe stärken das Vertrauen der Investoren in das Unternehmen, vereinfachen das IPO und führen daher insgesamt zu einer höheren Bewertung. ${ }^{24}$ Es ist daher essentiell, die Gesellschaft bereits vor dem Börsengang auf die erhöhten Ansprüche der Börse und der verschiedenen market players vorzubereiten.

Im Rahmen eines geplanten Börsengangs an einer Schweizer Börse sollten IPO-Kandidaten dabei insbesondere folgenden Gesetzen und Regularien Beachtung schenken:

- Verordnung gegen übermässige Vergütungen bei börsenkotierten Aktiengesellschaften („VegüV“): Die VegüV ist am 1. Januar 2014 als Folge der Volksinitiative "gegen die Abzockerei“ in Kraft getreten. Sie wird im Rahmen der "grossen“ Aktienrechtsversion auf Stufe eines formellen Gesetzes umgesetzt. ${ }^{25}$ Die entsprechenden Bestimmungen sollen die Auszahlung übermässiger Vergütungen der Gesellschaft an die Mitglieder der Leitungsorgane verhindern. Es wird insbesondere geregelt, welche Arten von Vergütungen unzulässig sind und welche Bestimmungen börsenkotierte Gesellschaften im Zusammenhang mit Vergütungen in die Statuten aufnehmen müssen. Die Rechte der Aktionäre, insbesondere das Mitwirkungsund Mitspracherecht, wurden erheblich gestärkt; so bedürfen sämtliche Vergütungen der Leitungsorgane der Zustimmung der Generalversammlung. Zudem müssen börsenkotierte Aktiengesellschaften einen Vergütungsausschuss bilden, der aus Mitgliedern des Verwaltungsrats bestehen muss. In einem jährlich zu erstellenden Vergütungsbericht ist der Verwaltungsrat ferner verpflichtet, Vergütungen, Kredite und Darlehen offenzulegen, die die Gesellschaft an die Mitglieder der Führungsorgane und ihnen nahestehenden Personen ausgerichtet hat. Schliesslich ist in der VegüV (i) eine Einzelwahl der Mitglieder des Verwaltungsrats und des Vergütungsausschusses, (ii) die Wahl des Präsidenten des Verwaltungsrats und (iii) die Bestimmung eines unabhängigen Stimmrechtsvertreters durch die Generalversammlung vorgesehen.

- Richtlinie betr. Informationen zur Corporate Governance der SIX Swiss Exchange: Diese Richtlinie verpflichtet Emittenten, ihren Aktionären bestimmte in einem Anhang aufgeführte Schlüsselinformationen zur Cor-

Vgl. Frey Martin, IPO Readiness Check, in: Going Public-Guide (vgl. Fn. 20), 27.

Vgl. Entwurf vom 23. November 2016 zur Änderung des Obligationenrechts (Aktienrecht; EOR; BBI 2017683 ff.). 
porate Governance in einem separaten Kapitel des Geschäftsberichts zugänglich zu machen. Äussern muss sich die Emittentin insbesondere zu folgenden Themenbereichen:

- Konzernstruktur und Aktionariat

- Kapitalstruktur

- Verwaltungsrat

- Geschäftsleitung

- Entschädigungen, Beteiligungen und Darlehen

- Mitwirkungsrechte der Aktionäre

- Kontrollwechsel und Abwehrmassnahmen

- Revisionsstelle

- Informationspolitik

Dabei sollen sich die Emittenten auf das für die Investoren Wesentliche beschränken und die Informationen in einer sachgerechten und verständlichen Weise darlegen, wobei die Offenlegung dem „comply or explain“Prinzip unterliegt. Sieht eine Emittentin demnach von der Offenlegung von bestimmten Informationen ab, so ist dies im Geschäftsbericht explizit zu erwähnen und die Abweichungen sind einzeln und substantiell zu begründen.

- Swiss Code of Best Practice for Corporate Governance („SCBP“): Beim SCBP handelt es sich um vom economiesuisse, dem Verband der Schweizer Unternehmen aus allen Branchen, erlassene Leitlinien und Empfehlungen, die sich an schweizerische Publikumsgesellschaften richten. Die enthaltenen Empfehlungen können nicht unmittelbar durch rechtliche Sanktionen durchgesetzt werden. Da sie sich aber als allgemeiner Standard weitgehend etabliert haben, kann es sich eine Emittentin nicht leisten, diese Richtlinien einfach zu ignorieren. Die Regulierung erfolgt daher gewissermassen durch den Markt selbst. Die im SCBP enthaltenen Empfehlungen äussern sich unter anderem zur Ausgestaltung und Verstärkung der Aktionärsrechte wie beispielsweise dem Zugang zu Informationen und die Ausübung der Stimm- und Mitspracherechte sowie zur Organisation, Zusammensetzung und Arbeitsweise des Verwaltungsrats sowie die Unabhängigkeit seiner Mitglieder. ${ }^{26}$ 


\section{d) Organisation der Führungsebene}

Investoren börsenkotierter Unternehmen haben hohe Anforderungen an die Personen im Verwaltungsrat und in der Geschäftsleitung. Gerade bei IPOKandidaten aus dem Venture Capital-Bereich trifft man häufig gründerdominierte Strukturen an, was im Markt kritisch betrachtet wird. Es ist vorteilhaft, wenn man den potentiellen Anlegern Führungspersonen präsentieren kann, die bereits über relevante Marketing-, Führungs-, Entwicklungs-, und Finanzerfahrung mit börsenkotierten Unternehmen verfügen. Unter Umständen ist daher eine Ergänzung der Leitungsebene mit geeigneten Personen oder eine komplette Neuorganisation der Führungsebene angezeigt. Der zeitliche und organisatorische Aufwand im Zusammenhang mit dem entsprechenden Rekrutierungsprozess muss bei der Planung des IPO unbedingt miteinkalkuliert werden und ist nicht zu unterschätzen. Die Suche nach erfahrenen Führungskräften kann je nach Branche durchaus ein Jahr in Anspruch nehmen. Die Leitungsorgane sollten ausgewogen zusammengesetzt sein. Bei der Zusammensetzung darf insbesondere auch den Empfehlungen des SCBP Beachtung geschenkt werden. Wichtig ist demnach insbesondere, dass

- der Verwaltungsrat genügend klein ist, damit eine effiziente Willensbildung möglich ist, aber auch genügend gross ist, damit seine Mitglieder Erfahrung und Wissen aus verschiedenen Bereichen ins Gremium einbringen und die Funktion von Leitung und Kontrolle unter sich verteilen können;

- dem Verwaltungsrat Mitglieder beider Geschlechter ${ }^{27}$ angehören;

- bei den Mitgliedern des Verwaltungsrats eine angemessene Diversität der Mitglieder sichergestellt ist;

- eine Mehrheit der Mitglieder des Verwaltungsrats unabhängig und damit nicht exekutiv ist; und

- im Fall einer Gesellschaft, die in erheblicher Weise im Ausland tätig ist, auch Personen mit langjähriger internationaler Erfahrung oder ausländische Mitglieder dem Verwaltungsrat angehören. ${ }^{28}$

Die hiervor erwähnten Prinzipien sollten natürlich auch bei der Zusammenstellung der Geschäftsleitung nicht ausser Acht gelassen werden.

In diesem Zusammenhang ist zu erwähnen, dass die zusätzlichen Pflichten rechtlicher und regulatorischer Art, welche Mitglieder der Leitungsorgane

Vgl. auch Art. 734f E-OR, der vorsieht, dass bei grösseren Publikumsgesellschaften jedes Geschlecht zu mindestens 30\% im Verwaltungsrat und zu 20\% in der Geschäftsleitung vertreten sein soll. Ist dies nicht der Fall, so müssen die Gründe und die Massnahmen zur Förderung des weniger stark vertretenen Geschlechts künftig im Vergütungsbericht angegeben werden (der Gesetzesentwurf sieht gewisse Übergangsfristen vor). SCBP, 10. 
bei einem börsenkotierten Unternehmen übernehmen, kombiniert mit einem erhöhten öffentlichen Interesse, auch etliche Risiken mit sich bringen, welchen sich die Mitglieder der Führungsebene notwendigerweise aussetzen müssen. Nicht selten verpflichten sich börsenkotierte Unternehmen zu gewissen Schadloshaltungen und/oder es wird auf sogenannte D\&O-Versicherungen zurückgegriffen, die den betroffenen Mitgliedern der Führungsorgane allfällige Prozess- und Parteikosten und weitere Auslagen, für die sie haftbar sind, ersetzen sollen. In den meisten Fällen dürfte es sicherlich angezeigt sein, bereits vor dem IPO entsprechende Vorkehrungen zu treffen.

\section{e) Technische Anforderungen}

Im Rahmen eines IPO muss häufig festgestellt werden, dass bestehende Programme, Systeme und Abläufe den Anforderungen eines börsenkotierten Unternehmens nicht mehr ausreichend gerecht werden können. Zu den Vorbereitungshandlungen eines IPO gehört daher auch die Prüfung, ob die Systeme dem zu erwartenden Wachstum der Gesellschaft Rechnung tragen können und in der Lage sind, die Informationen so zu verarbeiten, dass die neuen Anforderungen an die Offenlegung und Compliance erfüllt werden können. $\mathrm{Zu}$ den Bereichen, die besonders risikobehaftet sind, gehören insbesondere Buchhaltungssysteme, HR-Systeme sowie Systeme betreffend das Management von Kundenbeziehungen.

\section{4. Überwindung bestimmter praktischer Hindernisse}

\section{a) Pläne der aktuellen Eigentümer}

Es versteht sich von selbst, dass ein IPO der Mitwirkung der aktuellen Eigentümer der potentiellen Emittenten bedarf. Es kann daher vorkommen, dass ein IPO-Projekt bereits an der Einstellung und den Plänen der bestehenden Aktionäre scheitert.

Bevor Pläne über ein IPO geschmiedet werden, sollte im bestehenden Aktionariat Einigkeit darüber bestehen, ob ein IPO kurz- oder mittelfristig überhaupt in Frage kommt. Gerade wenn das IPO als möglicher Exit dienen soll, kommt es vor, dass gewisse Aktionäre einen Privatverkauf vorziehen würden, weil sie sich so einen höheren Verkaufserlös erhoffen. Dies auch vor dem Hintergrund, dass bei einem IPO in der Regel ein Discount in der Höhe von durchschnittlich 10\% gewährt werden muss, um einerseits die Investoren für ihre Risikobereitschaft zu entschädigen und um andererseits sicherzustellen, dass sich der 
Börsenkurs vielversprechend entwickelt. ${ }^{29}$ Möglich ist auch, dass einige Aktionäre mit einem IPO noch zuwarten möchten, weil sie mit einer Steigerung der Bewertung rechnen und sich dadurch bei einem späteren Exit, sei es mittels IPO oder durch Privatverkauf, einen höheren Verkaufserlös erhoffen.

Hinzu kommt, dass sich die bisherigen Aktionäre oft auch nach einem IPO eine Beherrschung des Unternehmens, insbesondere über die Kontrolle der Stimmrechte an der Generalversammlung oder über den Verwaltungsrat, wünschen, in das sie viele Jahre ihr Herzblut gesteckt haben oder das seit Jahrzehnten im Besitz der Familie ist. Dies liesse sich zum Beispiel durch die Schaffung separater Wertpapierkategorien wie Stimmrechtsaktien oder Partizipationsscheinen erreichen, womit bestimmten Aktionären auch nach dem IPO besondere Rechte gewährt werden können. ${ }^{30}$ Die Ausgabe von Wertpapieren „zweiter Klasse“ wirkt sich jedoch selbstverständlich auf den Preis aus. Dies lässt sich oft nur schwer mit dem Ziel vereinbaren, viel Kapital zu einer sehr hohen Bewertung aufzunehmen. Erschwerend kommt dabei hinzu, dass Investoren genügend free float erwarten (siehe dazu auch oben, II.1.b).

Möchte man später keine bösen Überraschungen erleben, ist es zusammengefasst sicher ratsam, die bestehenden Aktionäre oder zumindest jene, die über weitgehende Mitsprache- und Kontrollrechte verfügen, im Hinblick auf ein geplantes IPO bereits früh an Bord zu holen und sie in die wesentlichen Entscheide miteinzubinden.

\section{b) Abschreckung vor hoher Transparenz}

Mangels abweichender Regelung in Verträgen, wie insbesondere Aktionärsbindungsverträgen, sind die Offenlegungspflichten für Aktionäre einer privat gehaltenen Gesellschaft minimal. Dies ändert sich, sobald die Gesellschaft den Schritt auf das Börsenparkett wagt. Bereits im Rahmen des Kotierungsverfahrens ist ein Prospekt einzureichen, der die für einen Entscheid der potentiellen Investoren wesentlichen Angaben betreffend die Emittentin enthalten muss. Neben Informationen zum Verwaltungsrat, der Geschäftsleitung, der Revisionsstelle und allfälliger weiterer Organe sowie die letzten Jahresrechnungen, sind auch Informationen über die Geschäftslage sowie wesentliche Perspektiven, Risiken und Streitigkeiten preiszugeben. Schliesslich muss der

$29 \quad$ IPO-Guide (vgl. Fn. 5), 21.

30 So beispielsweise bei der Metall Zug AG und der Zug Estates Holding AG; bei beiden Gesellschaften wurden im Zuge der damaligen Ausgliederung und Kotierung Stimmrechtsaktien ausgegeben. 
Prospekt auch Angaben zu den angebotenen Effekten und dem Angebot selbst wie namentlich die Art der Platzierung und den geschätzten Nettoerlös der Emission bekanntmachen. ${ }^{31}$

Auch und gerade nach dem Börsengang haben börsenkotierte Unternehmen weitgehende Informationspflichten gegenüber ihren Investoren und der Öffentlichkeit. Jene sollen eine kontinuierliche Transparenz betreffend das Unternehmen sicherstellen. Dabei unterscheidet die SIX Swiss Exchange zwischen wiederkehrenden und ereignisbezogenen Pflichten.

Die wiederkehrenden Pflichten sind periodische und planbare Informationsund Ausweispflichten. Die sogenannten Regelmeldepflichten als erste Untergruppe dieser wiederkehrenden Pflichten, betreffen technische und administrative Informationen zu der Emittentin und zu den Effekten. Darunter fallen beispielsweise Änderungen des Namens oder des Sitzes der Emittentin, Veränderungen der Kapitalstruktur, Informationen zu einer Dividende, der Generalversammlung sowie die Anpassung von Weblinks. Ziel dieser Regelung ist es sicherzustellen, dass der Börse und den Markteilnehmern die entsprechenden Informationen über die kotierten Effekten rechtzeitig und in geeigneter Form zur Verfügung stehen.

Ferner ist ein börsenkotiertes Unternehmen verpflichtet, ein wahrheitsgetreues Bild über die Finanz- und Ertragslage zu vermitteln. Wesentlicher Bestandteil davon sind insbesondere die Publikation des Jahresberichts innerhalb von vier Monaten nach Abschluss des Geschäftsjahres sowie allfällige Zwischenberichte innerhalb von drei Monaten nach Ende der betreffenden Periode.

Letztlich sind in diesem Zusammenhang auch auf die bereits diskutierten Pflichten zur Offenlegung bestimmter Informationen betreffend Corporate Governance im Geschäftsbericht zu verweisen (siehe oben, II.3.c).

Bei den ereignisbezogenen Pflichten handelt es sich demgegenüber um Publikationspflichten, die unregelmässig auftreten und die Emittentin verpflichten, ihre Investoren und die Öffentlichkeit über ein bestimmtes Ereignis zu informieren. Im Rahmen der Ad-hoc-Publizität sind potentiell kursrelevante, aber nicht öffentlich bekannte Tatsachen, die eine Emittentin betreffen, bekanntzugeben. Dies kann beispielsweise Änderungen betreffend den Gewinn, Umstrukturierungen oder personelle Änderungen der obersten Führungsebenen betreffen.

31 Art. 40 FIDLEG. 
Zudem müssen börsenkotierte Unternehmen Transaktionen gewisser Finanzinstrumente durch die Mitglieder ihrer Verwaltungs- und Geschäftsführungsorgane offenlegen.

Letztlich trifft auch die Aktionäre von börsenkotierten Gesellschaften eine Offenlegungspflicht. Sie müssen unter anderem beim Erreichen, dem Überoder dem Unterschreiten von Stimmrechts-Grenzwerten in der Höhe von 3\%, $5 \%, 10 \%, 15 \%, 20 \%, 25 \%, 33 \frac{1}{3} \%, 50 \%$ oder $662 / 3 \%$ eine entsprechende Meldung an die Emittentin und die Offenlegungsstelle einreichen. ${ }^{32}$

Der Gang an die Börse und die anschliessende Aufrechterhaltung der Kotierung geht Hand in Hand mit einem Verlust der Privatsphäre. Es müssen Facetten des Geschäfts einer Gesellschaft, ihrer Aktionäre und ihrer Finanzen an Mitstreiter, Klienten und Arbeitnehmer offengelegt werden, die vorher ausser den obersten Führungsorganen einer Gesellschaft niemandem bekannt waren. Es ist daher durchaus nachvollziehbar, dass sich die Eigentümer einer Gesellschaft, sobald sie sich mit diesen zahlreichen Offenlegungspflichten auseinandergesetzt haben, gegen eine Börsenkotierung entscheiden. Vor diesem Hintergrund ist wichtig, dass die entsprechenden Protagonisten (insbesondere bei Familienunternehmen) früh über die signifikant höhere Transparenz bei Publikumsgesellschaften aufgeklärt werden.

\section{c) Respekt vor hohen Kosten}

Ein IPO und das anschliessende „Leben“ als börsenkotierte Gesellschaft ist mit Kosten verbunden. Ein IPO wird in der Regel engmaschig von einem Team aus Experten, insbesondere den Syndikatsbanken, Rechtsanwälten, Revisoren und PR-Beratern unterstützt. Es versteht sich von selbst, dass für die entsprechenden Honorare erhebliche Kosten anfallen. Auch die Börse stellt gewisse Gebühren in Rechnung, die teilweise von der Kapitalisierung des Unternehmens abhängen. Es muss davon ausgegangen werden, dass sich die Gesamtkosten eines IPO in der Regel auf $2 \%$ bis $5 \%$ der Transaktionssumme belaufen. ${ }^{33}$ Auch nach dem Börsengang dürften die erhöhten Anforderungen, insbesondere betreffend die Kommunikation mit den Investoren, die Rechnungslegung, die Offenlegung und Corporate Governance wie auch die Organisation und Infrastruktur, sowohl intern zu einem höheren Aufwand wie auch extern zu höheren Kosten (beispielsweise für Berater) führen. Zwar ist davon

32 Art. 120 FinfraG; vgl. zum ganzen Abschnitt die Übersicht unter <https://www.sixgroup.com/dam/download/the-swiss-stock-exchange/listing/equity/services-forequity-issuers/ssx_bpchecklist_de.pdf>.

Vgl. <https://www.kmu.admin.ch/kmu/de/home/aktuell/monatsthema/2019/der-boersengang-ein-reifeprozess-fuer-unternehmen.html>. 
auszugehen, dass eine Kandidatin für einen Börsengang, welche die notwendige Kapitalisierung aufbringt, auch solche Mehrkosten stemmen könnte, dennoch sollte ihre Höhe nicht unterschätzt werden.

\section{d) Vertragliche Schranken}

Es kommt weiter vor, dass gewisse Hindernisse in vertraglicher Hinsicht bestehen, die vor dem kick-off des IPO-Projekts behoben werden müssen. So ist es möglich, dass die bestehenden Eigentümer in einem Aktionärsbindungsvertrag hohe Quoren für ein IPO festgelegt haben oder dass beim Entwurf des Aktionärsbindungsvertrages der Möglichkeit eines IPO keine Beachtung geschenkt wurde und deswegen eine fehlerhafte Struktur gewählt worden ist (z.B. bei der Regelung einer Vorzugsdividende im Falle eines Exits).

Ferner kann sich ein gewähltes Vertragssetup als hinderlich erweisen. Hängt ein Grossteil der Geschäftstätigkeit und des Umsatzes von einem einzigen Vertragspartner ab und lässt sich der zugrundeliegende Vertrag einfach beenden, so dürfte dies den Investoren ein zu hohes Risiko sein. Um zu vermeiden, dass entsprechende Schranken erst im Due Diligence-Prozess erkannt werden, empfiehlt es sich daher, bereits vor dem kick-off einen Blick auf die von der Gesellschaft oder ihren Aktionären abgeschlossenen Verträge zu werfen, um potentielle Problemfelder möglichst früh zu identifizieren. 



\title{
Pre-Deal Research Reports in Initial Public Offerings: An Internationally Diverse Approach
}

\author{
Christina Del Vecchio*
}

\section{Content}

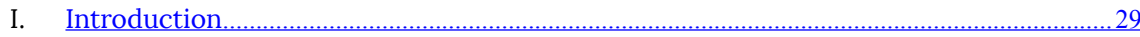

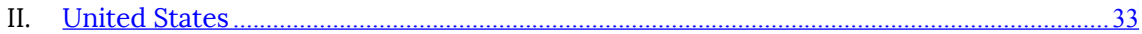

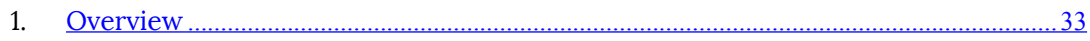

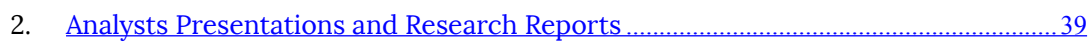

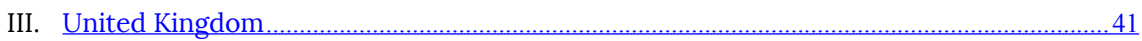

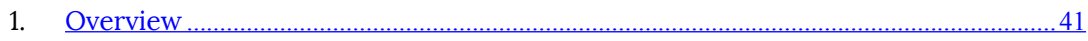

2. Analysts Presentations and Research Reports ……………………………....................... 44

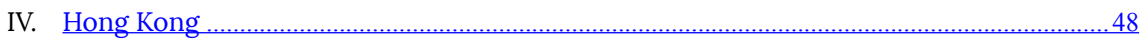

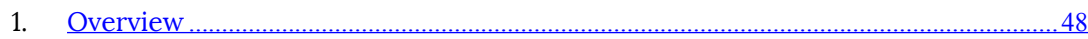

2. Analysts Presentations and Research Reports ……………………………………....51

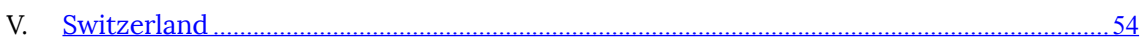

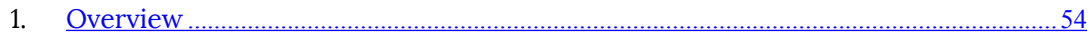

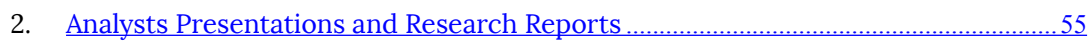

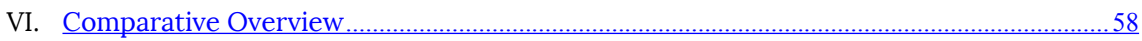

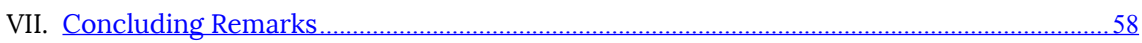

\section{Introduction}

The securities market ecosystem involves a number of players with varying roles. At the core of this ecosystem are the corporate issuers, on the one hand, and the universe of investors, on the other hand. The relationship between the corporate issuers and the investors is mediated by a myriad of legal regimes and regulations, all of which aim to ensure that the securities markets in the respective jurisdictions are, among other things, highly functioning,

* The following article presents a high level overview of the use of pre-deal research reports in initial public offerings in selected jurisdictions and is not intended to be fully comprehensive, conclusive or address all legal aspects and regimes that may govern predeal research reports in the identified jurisdictions. The following article presents the views and opinions of the author only. 
transparent, efficient and fair. While corporate issuers and investors primarily rely on the regulators or entities charged with the oversight of such markets to ensure compliance with applicable legal and regulatory regimes, there are a number of other players within this ecosystem that contribute to the ongoing functioning, transparency, efficiency and integrity of securities markets, including auditors, rating agencies and securities analysts. Indeed, legal scholars have often identified these entities as among the several "gatekeepers" in securities markets that, by pledging their so-called reputational capital to the corporate issuer, the gatekeepers "assure investors as to the quality of the 'signal' sent by a corporate issuer".

As among the "gatekeepers" of securities markets, securities analysts (also known as research analysts, equity analysts or investments analysts) essentially perform financial analysis for external or internal financial clients, largely in the form of research coverage. One of the greatest advantages of ongoing research coverage by securities analysts is, in principle, the "independent" assessment of the issuer's financial performance within the current macro-economic environment as well as how that compares with peers, whether within a specific industry sector or geography. In addition, ongoing coverage by securities analysts providing concise information and analyses on a corporate issuer to the buy-side investment community is among the essential components to increasing the visibility of a corporate issuer's shares and maintaining an active and liquid trading.

A corporate issuer's relationship with securities analysts typically begins (or develops more in earnest) with its initial public offering (IPO). ${ }^{2}$ Generally, connected analysts (i.e., those securities analysts from the same financial institutions that are participating as underwriters in the IPO banking syndicate) are introduced to a corporate issuer at so-called analyst presentations or analyst days, which can range from a daylong event to multi-day sessions, during which the company presents its business, strategy and financial performance in recent periods. Oftentimes, these events are accompanied by a tour of the company's headquarters or significant facilities along with live demonstrations of key product offerings or business lines. Securities analysts will then use the information provided and learned at such events as a basis for their own independent assessment, valuation and financial model of the

1 Coffee JR. John C., Why Do Auditors Fail? What Might Work? What Won't?, European Corporate Governance Institute (ECGI) Law Working Paper No. 436/2019, Columbia Law School Center for Law \& Economic Studies Working Paper No. 597 (January 2019).

2 Prior to an initial public offering corporate issuers may have listed debt instruments on the capital markets. 
corporate issuer, which typically includes financial forecasts for the next three to five years. In a number of jurisdictions outside the United States, securities analysts will then publish their findings in pre-deal research reports, which (as their name suggests) are published in the weeks leading up to a corporate issuer's launch of its IPO. In addition to the publication of pre-deal research reports, securities analysts may also hold meetings or sessions with clients or potential investors to discuss their views and assessment of a corporate issuer's potential IPO. In many jurisdictions, the publication of pre-deal research reports and/or the accompanying investor meetings are regarded as key elements of investor education as well as a vital source of price discovery (i.e., the potential value of the corporate issuer's shares). ${ }^{3}$

Importantly, depending on the facts and circumstances and in light of the short temporal time period between the publication of pre-deal research reports and the launch of the book-building process in an IPO, the publication of pre-deal research reports raises a number of potential issues. In many jurisdictions the scope of liability around pre-deal research reports is not clearly defined and could potentially give rise to a number of legal claims and causes of action. In the United States, for example, the general antifraud provision outlined in Section 10(b) of the U.S. Securities Exchange Act of 1934 and Rule 10b-5 provide broad basis for both civil and criminal liability in connection with securities transactions and extends to "any person" as well as to both oral and written statements, whether or not relating to a disclosure document. ${ }^{4}$ In addition to fraud and/or prospectus liability issues, concerns that the research report could be deemed by a court or regulator as an offer to sell securities, potentially running afoul securities laws or regulations relating to timing issues or other technical aspects of the respective regulatory regime, have to be considered. ${ }^{5}$ These arguments become further complex for pre-deal research reports published by connected analysts as well as by the active role that companies and advisors take in the preparation of analysts presentations and the subsequent review of pre-deal research reports prior to their publication for factual accuracy. While generally the issuer and other advisors are not permitted to comment on the opinions made by securities

3 See e.g., UK Financial Conduct Authority, Consultation Paper, Reforming the availability of information in the UK equity IPO process, March 2017 (hereinafter FCA Consultation Paper March 2017), para 1.7 .

4 U.S. Securities and Exchange Commission (the "SEC") Rule 10b-5 codified at 17 Code of Federal Regulations (CFR) $\S 240.10 b-5$ enacted by the SEC pursuant to $\S 10$ of the U.S. Securities Exchange Act of 1934 (as amended) (the "U.S. Exchange Act") (hereinafter Rule 10b-5).

5 See e.g., U.S. Securities Act of 1933 (as amended) (U.S. Securities Act) Section 12(a)(2) of the, 15 U.S.C. $\S 771(a)(2)$. 
analysts nor are they asked to "approve" the pre-deal research reports, if significant factual inaccuracies exist in pre-deal research reports, this could create potential liability issues that may be challenging to navigate.

On top of possible legal and regulatory issues, pre-deal research reports published by connected analysts also raise certain conflict of interest concerns increasing the risk that the content of such pre-deal research reports may be biased. Specifically, the investment banking team participating in the underwriting syndicate owes certain duties to the corporate issuer pursuant to their documented engagement in the IPO process and has a financial interest in the success of the IPO through its commission and fee arrangements. ${ }^{6}$ On the other hand, the securities analysts at the same financial institutions responsible for the publication of pre-deal research reports owe certain corresponding duties to the buy-side investors that either purchase such research or are clients of the financial institution. Thus, if sufficient controls and measures are not in place at a financial institution to address such potential conflict of interests, there are heightened risks that connected analysts may not only have access to certain or additional non-public information that will not be included in the offering documents, but (and perhaps most importantly) may also be pressured to publish favorable predeal research reports to both secure a position within the IPO underwriting syndicate and drive the share valuation of a corporate issuer. As certain regulators have found, such biased and non-objective analyses could directly influence investors' decisions and compromise the integrity and efficiency of the price discovery process in IPOs. ${ }^{7}$

As a result of these combined factors, the nature of the relationship between corporate issuers and securities analysts, as well as the approach to marketing IPOs by the investment banking teams, has evolved and diverged rather significantly over the last twenty years and across certain of the world's most significant securities markets. To date, international regulators have largely focused on safeguarding securities analysts' independence and objectivity in light of potential conflicts of interest between securities analysts and the corporate finance/investment banking divisions of the same financial institutions and potential biases that could present in pre-deal research reports as a result. Financial regulators have tried to address such issues

6 See e.g., FCA Consultation Paper March 2017, para 1.3; Securities and Exchange Commission, Ten of Nation's Top Investment Firms Settle Enforcement Actions Involving Conflicts of Interest Between Research and Investment Banking, 28 April 2003, $<$ https://www.sec.gov/news/press/2003-54.htm> (hereinafter SEC Press Release April 2003).

7 See e.g., FCA Consultation Paper March 2017, para 1.3; SEC Press Release April 2003. 
through specific regulations as well by encouraging market driven measures. Such regulations and measures have led to, among others, the requirement of disclosure statements, ${ }^{8}$ limitations on the involvement of securities analysts in investment banking pitches, implementation of Chinese walls and "control rooms" within financial institutions ${ }^{9}$ and blackout periods..$^{10}$

In the following sections, this article will explore the regulatory approach to securities analysts and pre-deal research reports in IPOs across the United States, the United Kingdom and Hong Kong and how that compares with the approach used in Switzerland, which is generally representative of the approach used in much of Europe. ${ }^{11}$ This survey is followed by a comparative overview and a short commentary on the effectiveness of pre-deal research reports in investor education and efficient price discovery.

\section{United States}

\section{Overview}

When specifically considering the role of securities analysts and the publication of research reports in the United States, a short historical overview on the evolution of pre-deal research reports in the United States market is useful for contextualizing and better understanding the current approach.

From the mid-1990s through to 2001, the prices of stocks in technology companies on the New York exchanges soared in what became known as the "Dot-Com" bubble. In 2001, the bubble burst with the value of shares in many technology companies plummeting, leaving investors with considerable losses. ${ }^{12}$ Following the burst of the Dot-Com bubble, regulators, self-

8 See e.g., Regulation AC, (17 CFR $\S 242.500$ et seq.).

9 See e.g., Regulation AC, (17 CFR $\S 242.500$ et seq.)., FCA Handbook, Code of Business Sourcebook (COBS), COBS 11A.1-12; Financial Industry Regula-tory Authority (FINRA) Rule 2241.

10 See e.g., FINRA Rule 2241(b)(2)(H).

11 The sequence of events in IPOs in Switzerland is analogous to, for instance, approaches in Germany and Sweden; whereas the newly adopted approach is the UK is similar to what is followed in France (see e.g., UK Financial Conduct Authority, Discussion Paper, Reforming the availability of information in the UK equity IPO process, April 2016 [hereinafter FCA Discussion Paper April 2016], para 1.10).

12 LuX Marshall/PeAd JaCK, Hunting High and Low: The Decline of the Small IPO and What to Do About It, M-RCBG Associate Working Paper Series No. 86 (April 2018), Mossavar-Rahmani Center for Business \& Government or of Harvard University, p. 6. 
regulatory organizations (SROs) and prosecutors began looking more closely at what drove the significant over-valuation of many technology companies during this period. Among other factors ${ }^{13}$ allegations of research reports tainted by investment banking conflicts used in connection with the IPOs for a number of these Dot-Com companies came under scrutiny.

Following investigations led by the combined forces of the U.S. Securities and Exchange Commission (SEC), NASD Inc. (NASD), the New York Stock Exchange, Inc. (NYSE), the New York Attorney General and several other state regulators, significant instances of inappropriate influence and conflicts of interest among securities analysts and the investment banking arm of the same financial institutions were uncovered. ${ }^{14}$ With regard to research reports, the enforcement actions alleged that several institutions had issued fraudulent research reports ${ }^{15}$ as well as "research reports that were not based on principles of fair dealing and good faith and did not provide a sound basis for evaluating facts, contained exaggerated or unwarranted claims about the covered companies, and/or contained opinions for which there were no reasonable bases"16 ${ }^{\prime 1}$ In several instances, it was further alleged that the remuneration of securities analysts was influenced, either directly or indirectly, by the performance of or input from the investment banking arm of financial institutions. For example, the enforcement action alleged that securities analysts were incentivized, including via their compensation and bonus, to maximize the fees and proceeds generated by the investment banking arm in activities such as IPOs. ${ }^{17}$ In addition, the SEC found evidence

13 Certain other identified factors included Y2K concerns and aggressive venture capital enthusiasm.

14 See SEC Press Release April 2003 (Fn. 6).

15 Securities and Exchange Commission, Securities and Exchange Commission (2003), SEC sues Credit Suisse First Boston for Research Analyst Conflicts of Interest Firm to Settle with SEC, NASD, NYSE, NY Attorney General, and State Regulators, 28 April 2003, <https://www.sec.gov/litigation/litr eleases/lr18110.htm> (SEC CSFB Litigation Release April 2003). "CSFB issued fraudulent research reports on two companies: Digital Impact, Inc. and Synopsys, Inc. In both cases, research analysts expressed positive views of the companies' stocks that were contrary to their true, privately held beliefs. In these instances, investment bankers pressured research analysts to initiate or maintain positive research coverage to obtain or retain investment banking business, and the analysts were pressured or compelled to compromise their own professional opinions regarding the companies at the direction of the firm's investment bankers". See SEC Press Release April 2003 (Fn. 6).

17 Securities and Exchange Commission, SEC sues UBS Warburg for Research Analyst Conflicts of Interest Firm to Settle with SEC, NASD, NYSE, NY Attorney General, and State Regulators, 28 April 2003, <https://www.sec.gov/litigation/litreleases/lr18112.htm>. 
in certain pitch materials that implied to potential investment banking clients that a financial institution's securities analysts would provide positive coverage if selected as part of the IPO underwriting syndicate and that such coverage would have a correlating positive impact on the company's share price. ${ }^{18}$ In addition to failing to address conflict of interest issues by not separating the research divisions from investment banking divisions, the enforcement actions further outlined a number of other inappropriate practices, including undisclosed payments received or made for research and IPO spinning. ${ }^{19}$

Ultimately, ten major financial institutions settled the enforcement actions in what became known as the Global Research Analyst Settlement (Global Settlement) on 28 April $2003 .{ }^{20}$ In addition to the significant monetary penalties of nearly $\$ 1.5$ billion, including $\$ 935$ million in penalties and disgorgement, $\$ 460$ million to fund independent research, and $\$ 85$ million to fund investor education, ${ }^{21}$ the settlement required the sanctioned banks to implement numerous structural reforms designed to minimize the influence of investment banking divisions on the securities research divisions. These structural reforms included, among other things, the physical separation of research and investment banking departments, the requirement of enhanced disclosures (including disclosure of potential conflicts of interests in research reports), the prohibition on the influence of or input from the investment banking department on the performance or remuneration of securities analysts and the prohibition of securities analysts from participating in efforts to solicit investment banking clients. ${ }^{22}$

18 Securities and Exchange Commission, SEC sues UBS Warburg for Research Analyst Conflicts of Interest Firm to Settle with SEC, NASD, NYSE, NY Attorney General, and State Regulators, 28 April 2003, <https://www.sec.gov/litigation/litreleases/lr18112.htm>.

19 See SEC Press Release April 2003 (Fn. 6).

20 See SEC Press Release April 2003. The original settlement included Bear Stearns, CSFB, Goldman Sachs, JP Morgan, Lehman Brothers, Merrill Lynch, Morgan Stanley, Citigroup, UBS Warburg, and U.S. Bancorp Piper Jaffray. Deutsche Bank and Thomas Weisel added in 2004 (see Securities and Exchange Commission, Deutsche Bank Securities Inc. and Thomas Weisel Partners LLC Settle Enforcement Actions Involving Conflicts of Interest Between Research and Investment Banking, 26 August 2004, <https://www.sec.gov/news/press/ 2004-120.htm>.

21 See Corwin Shane A./Larocque StePhannie/Stegemoller Mike, Investment Banking Relationships and Analyst Affiliation Bias: The Impact of the Global Settlement on Sanctioned and Non-Sanctioned Banks, Journal of Financial Economics, Volume 124, Issue 3, June 2017, pp. 614-631.

22 See Securities and Exchange Commission, SEC Fact Sheet on Global Analyst Research Settlements, 28 April 2003, <https://www.sec.gov/news/speech/factsheet.htm>. 
In addition to the structural reforms mandated through the Global Settlement on the sanctioned banks, lawmakers had also been evaluating the potential conflicts of interest involving securities analysts. ${ }^{23}$ As a result of these efforts, the U.S. Congress introduced the Sarbanes-Oxley Act (SOX) in 2002, where (among other measures) the SEC and securities industry SROs were specifically charged with addressing conflicts of interest involving securities analysts. $^{24}$ The SEC subsequently responded with Regulation Analyst Certification (Regulation AC) that outlined, among other things, various certification and disclosure requirements by securities analysts and others in connection with the publication of research reports and public appearances by securities analysts. ${ }^{25}$ Meanwhile, SROs similarly followed with the NYSE amending its rule 351 (Reporting Requirements) ${ }^{26}$ and rule 472 (Communications with the Public), ${ }^{27}$ and the NASD released rule 2711 (Research Analysts and Research Reports). ${ }^{28}$ These rule changes (as amended thereafter) imposed many of the same "structural" changes to address conflicts of interest between securities analysts and investment banking departments as stipulated in the Global Settlement as well as introducing quiet periods (i.e., the period during which no research may be published), but at an industry level. ${ }^{29}$

23 See Securities and Exchange Commission, Written Testimony Concerning Conflicts of Interest Faced by Brokerage Firms and Their Research Analysts, 31 July 2001, $<$ https://www.sec.gov/news/testimony/073101tslu.htm>.

See Section 501 of Sarbanes-Oxley Act of 2002, PL 107-204, 116 Stat 745 (codified at 15 U.S.C. $\S \S 7201-7266)$.

25 Regulation AC, (17 CFR $\S 242.500$ et seq.).

26 See Securities and Exchange Commission, NASD and NYSE Rulemaking: Proposed Rule Changes Relating to Exchange Rules 344, 345A, 351 and 472 and the National Association of Securities Dealers, Inc., 11 March 2003, <https://www.sec.gov/rules/sro/34-47110.htm>.

27 See Securities and Exchange Commission, NASD and NYSE Rulemaking: Proposed Rule Changes Relating to Exchange Rules 344, 345A, 351 and 472 and the National Association of Securities Dealers, Inc., 11 March 2003, <https://www.sec.gov/rules/sro/34-47110.htm>.

28 See Securities and Exchange Commission, Self-Regulatory Organizations: Notice of Filing of Amendment No. 2 to Proposed Rule Changes by the New York Stock Exchange, Inc. Relating to Exchange Rules 344 ("Supervisory Analysts"), 345A ("Continuing Education for Registered Persons"), 351 ("Reporting Requirements") and 472 ("Communications with the Public") and by the National Association of Securities Dealers, Inc. Relating to NASD Rule 2711 ("Research Analysts and Research Reports"), 22 May 2003, <https://www.sec.gov/rules/ sro/34-47912.htm>.

See CORWIN/LAROCQUE/STEGEMOlLER (Fn. 21). 
Since the Global Settlement ${ }^{30}$ and the enactment and implementation of the related laws, rules and regulations, the SEC and FINRA ${ }^{31}$ have revisited the practice of research reports several times. For example, in 2005, the SEC adopted "measured amendments" to Rules 137, 138 and 139 under the U.S. Securities Act that outlined certain safe harbors around research reports. As part of the Securities Offering Reform in 2005, the SEC provided a number of non-exclusive safe harbors that permits the issuance of research reports in the context of public offerings in certain outlined circumstances without such research being deemed an "offer" of securities under the U.S. Securities Act. ${ }^{32}$ However, these safe harbors relate only to research reports prepared in relation to issuers who have existing listed equity, so IPOs remained excluded. ${ }^{33}$ Furthermore, the SEC emphasized in their adopting release that despite their measured amendments, investor protection remained a key aspect and thus liability for research, including general anti-fraud liability, remains applicable. ${ }^{34}$

In 2012, as part of the Jumpstart Our Business Startups Act (JOBS Act) the SEC adopted a number of reforms to address the declining number of IPOs in the United States and facilitate access to the capital markets by companies that qualify as emerging growth companies (EGCs) ${ }^{35}$ As part of these reforms, the SEC modified the restrictions around pre-deal research reports published in connection with offerings by EGCs. Specially, the JOBS Act excluded certain research reports on EGCs from qualifying as offers to buy or sell securities and prohibited timing restrictions around their publication. However, the SEC reiterated that the JOBS Act did not amend or modify the terms of the Global

30 The Global Settlement was modified on 5 March 2010, but significant structural components remain in place (see Securities and Exchange Commission, Court Approves Modifications to Global Research Analyst Settlement, 19 March 2010,

$<$ https://www.sec.gov/litigation/litreleases/2010/lr21457.htm>.

31 FINRA is a not-for-profit organization authorized by Congress to protect America's investors by making sure the broker-dealer industry operates fairly and honestly. FINRA was created in 2007 as the result of the consolidation of the National Association of Securities Dealers (NASD) and the member regulation, enforcement and arbitration operations of the New York Stock Exchange (NYSE) (see <www.finra.org $>$ ).

32 Securities Offering Reform, Securities and Exchange Commission, Final Rule, 1 December 2005, (17 CFR parts 200, 228, 229, 230, 239, 240, 243, 249 and 274).

33 Securities Offering Reform, Securities and Exchange Commission, Final Rule, 1 December 2005, (17 CFR parts 200, 228, 229, 230, 239, 240, 243, 249 and 274).

34 See Securities Act Section 12(a)(2) and 17(a), Exchange Act Section 10(b) (15 U.S.C. 78j(b)), and Exchange Act Rule 10b-5 (17 CFR 240.10b-5).

35 Jumpstart Our Business Startups (JOBS) Act Pub. L. No. 112-106, 126 Stat. 206 (2012) (codified at 15 U.S.C. $§ 77-78)$. 
Settlement nor did the JOBS Act provide any safe harbor under the general anti-fraud provisions of the federal securities laws. ${ }^{36}$ In addition, the JOBS Act permits EGCs to meet with certain institutional investors in so-called "testing the waters" meetings where an issuer can evaluate investor interest in the company's potential offering. ${ }^{37}$ Typically, these "testing the waters" meetings occur after the first confidential filing with the SEC where initial feedback can be included and reflected.

Most recently, FINRA revisited certain of its regulations around securities analysts and research reports with the new FINRA Rule 2241 (Research Analysts and Research Reports) coming into force on 24 December $2015 .{ }^{38}$ FINRA Rule 2241 requires, among other things, applicable firms to establish, maintain and enforce written policies and procedures reasonably designed to identify and manage conflicts of interest in relation to research reports, public appearances and analysts' interactions with the investment banking team of the firm. ${ }^{39}$ Specifically, investment banking personnel are prohibited from (i) supervising or otherwise controlling securities analysts, (ii) retaliating against securities analysts based on a negative or unfavorable research report, (iii) any pre-publication review of research reports and (iv) certain forms of communications with securities analysts. ${ }^{40}$ In addition, securities analysts, other than in connection with an offering involving an EGC, "must not publish or otherwise distribute research reports, and securities analysts must not make public appearances, relating to the issuer for a minimum of 10 days following the date of an initial public offering if the member has participated as an underwriter or dealer in the initial public offering or a minimum of three days...if the member has acted as a manager or co-manager of that offering.".11

However, despite legislative and regulatory efforts, in the context of EGCs the practice of publishing and distributing pre-deal research reports in IPOs in the United States has not returned. ${ }^{42}$ Indeed, several regulatory, practical and factual limitations still exist. Specifically, the JOBS Act did not provide a safe

36 See Securities and Exchange Commission, Jumpstart Our Business Startups Act Frequently Asked Questions About Research Analysts and Underwriters, 22 August 2012, $<$ https://www.sec.gov/division s/marketreg/tmjobsact-researchanalystsfaq.htm>.

37 See supra Fn. 35.

38 See FINRA Rule 2241.

39 See FINRA Rule 2241(b).

40 See FINRA Rule 2241(b).

41 See FINRA Rule 2241(b)(2)(H).

42 Latham \& Watkins LLP, US IPO Guide (2019 Edition), 3 December 2019, p. 13 (hereinafter L\&W IPO Guide); see also Dixter David/Szaja Pawel, The JOBS Act and IPOs: the view from Europe, Capital Markets Briefing, Thomson Reuters (Professional) UK Limited (2015). 
harbor for research reports under federal and state anti-fraud provisions. ${ }^{43}$ In addition to the ongoing concerns around potential liability under the U.S. securities laws, absent any modification to the relevant court orders, the terms of the Global Settlement still apply to several of the largest financial institutions thereby effectively prohibiting the practice in offerings that they participate in. Furthermore, for both EGC and non-EGC IPOs, a customary 25-day research quiet period is still typically imposed through relatively standard research guidelines issued in connection with the IPO. ${ }^{44}$ This marketdriven syndicate-imposed research quiet period typically begins at the time an underwriter joins the offering syndicate and lasts until the 25th calendar day following the IPO effective date. ${ }^{45}$

\section{Analysts Presentations and Research Reports}

For corporate issuers pursuing an IPO in the United States, offerings generally follow the below timeline.

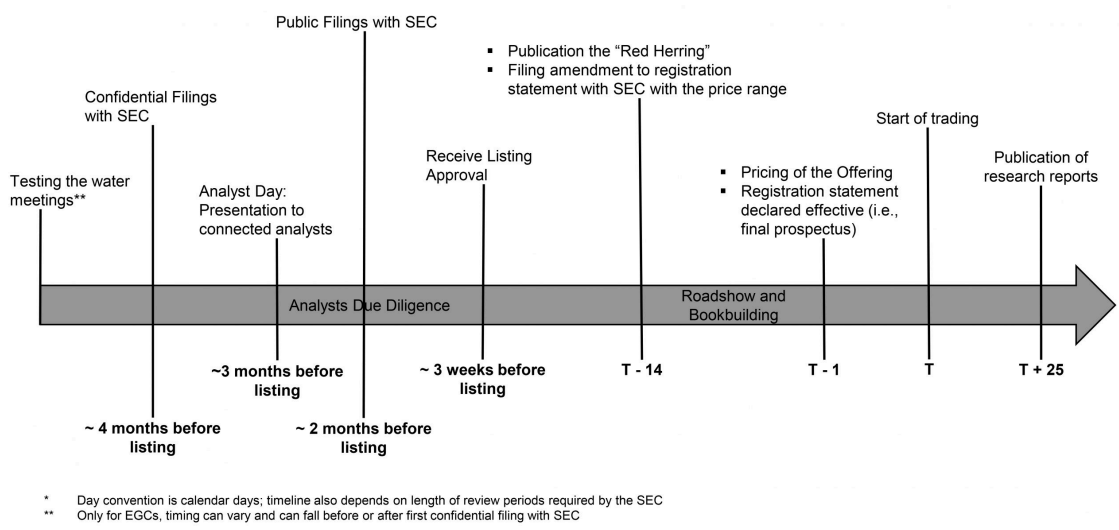

As discussed above, while pre-deal research reports are generally not published in connection with IPOs, even in the context of EGCs, ${ }^{46}$ the role of securities analysts in the United States is not limited to the publication of

\footnotetext{
43 See supra Fn. 36.

44 See L\&W IPO Guide supra Fn. 42, p. 13.

45 The IPO effective date means the date upon which the SEC declares the initial public offering of a corporate issuer's common stock as effective.

46 See supra Fn. 42.
} 
such reports. Specifically, they are also instrumental in educating a financial institution's sales force and are permitted to interact with investors (albeit separate from the corporate issuer). ${ }^{47}$ As a result, corporate issuers in the United States also begin their relationship with securities analysts during the period leading up to the launch of the IPO. Typically, the first official engagement with securities analysts occurs during so-called "analyst days." ${ }^{\text {"48 }}$

Analyst day presentations are usually delivered after the completion of several confidential filings with the SEC and, thus, after responding to several rounds of comments. This roughly translates into presentations occurring about halfway through the IPO process (circa three months before listing). Analyst day presentations typically comprise a full-day presentation by management. However, since at this stage in the IPO process, an advanced draft of the prospectus has been reviewed and commented on by the SEC and most of the substantive choices around the positioning of the corporate issuer have been made, these presentations are largely driven by the disclosure that has been so far agreed with the SEC and included in any "testing the waters" presentations that have been delivered by eligible EGC issuers. In addition, since the securities analysts will have access to the full disclosure document ahead of publishing any research reports, generally their focus at these presentations is on due diligence. Interestingly though, unlike in Europe, securities analysts will also be provided with the company's business model as well as management's projections for the next several years. ${ }^{49}$ This information is rather detailed and can comprise quarter-by-quarter projections for the next two years and then year-by-year projections for another year or so thereafter. These models are not generally reviewed by counsel and, thus, such granular information is also not typically included in the prospectus.

Following the analyst day, it is not uncustomary for securities analysts to have further due diligence sessions or communication with the management of the corporate issuer as they develop their understanding of the company, its business model and their views on valuation. Indeed, certain companies provide securities analysts with extensive due diligence sessions, which can include multi-day site visits, customer diligence sessions, one-on-one diligence sessions and other deep-dive sessions depending on the company's business model and industry. Importantly, each of these sessions is

47 See L\&W IPO Guide supra Fn. 42, pp. 7, 9; see also NYSE IPO Guide, Second Edition, 2013 Caxton Busi-ness \& Legal, Inc, p. 32.

48 See L\&W IPO Guide supra Fn. 42, pp. 7, 9; see also NYSE IPO Guide, Second Edition, 2013 Caxton Busi-ness \& Legal, Inc, p. 32.

49 See L\&W IPO Guide supra Fn. 42, pp. 7, 9; see also NYSE IPO Guide, Second Edition, 2013 Caxton Business \& Legal, Inc, p. 32. 
chaperoned by counsel to ensure that all information shared is consistent with the disclosure in the prospectus currently in the approval process with the SEC, as well as to ensure that none of the investment banking team members unduly influence the management's presentation or responses and thereby undermine the integrity of the due diligence sessions. ${ }^{50}$

In preparing their research reports, securities analysts will use the business model that the company has shared and the information that they have learned through various due diligence sessions to evaluate the corporate issuer and develop their own proprietary financial models. ${ }^{51}$ While research reports are only published after the quiet period, such securities analysts may orally discuss information generated by their proprietary financial models with either the sales team of their respective financial institutions or even communicate with potential investors after the offering has launched, but not yet priced (albeit separate from the corporate issuer's roadshow). In addition, while the analyst day presentations slides are reviewed at a high level and all diligence sessions chaperoned by counsel, the actual drafts of the research reports are typically not reviewed by the issuer or any counsel for factual accuracy. This is largely because such research reports are published after the quiet period, which can range from 3 or 10 to 25 days after the IPO effective date, ${ }^{52}$ as well as the fact that such reports should represent the independent view of the securities analysts in their evaluation of the company. Furthermore, at this stage all investors also have access to the approved registration statement, which should ultimately form the basis of an investor's decision to purchase shares of the corporate issuer.

\section{United Kingdom}

\section{Overview}

Supplementing the legal framework regulating securities transactions and the securities markets in the United Kingdom (UK), ${ }^{53}$ the UK financial regulator and listing authority (i.e., the Financial Conduct Authority [FCA]) has published rules and regulations that govern the conduct of relevant market players,

\footnotetext{
$50 \quad$ See supra Fn. 30; see also FINRA Rule 2241.

51 See supra Fn. 44.

52 See FINRA Rule 2241(b)(2)(H); see supra Fn. 44.

53 See e.g., the Financial Services and Markets Act of 2000 and the Financial Services Act of 2012.
} 
including sponsors ${ }^{54}$ and other advisers involved in UK IPOs. Specifically, the Conduct of Business Sourcebook (COBS) published by the FCA outlines the day-to-day conduct rules of financial firms carrying out, among other activities, investment business and, in connection therewith, specific rules relating to the provision of investment research. ${ }^{55}$

On 1 July 2018, the FCA amended the conduct rules relating to communications in Main Market IPOs ${ }^{56}$ in the UK that, among other things, restructured the sequencing around the publication of pre-deal research reports in UK IPOs. Prior to the reforms, typical UK IPO processes followed the below approach, which is more or less the standard approach currently used across most countries in Europe, including Switzerland. ${ }^{57}$

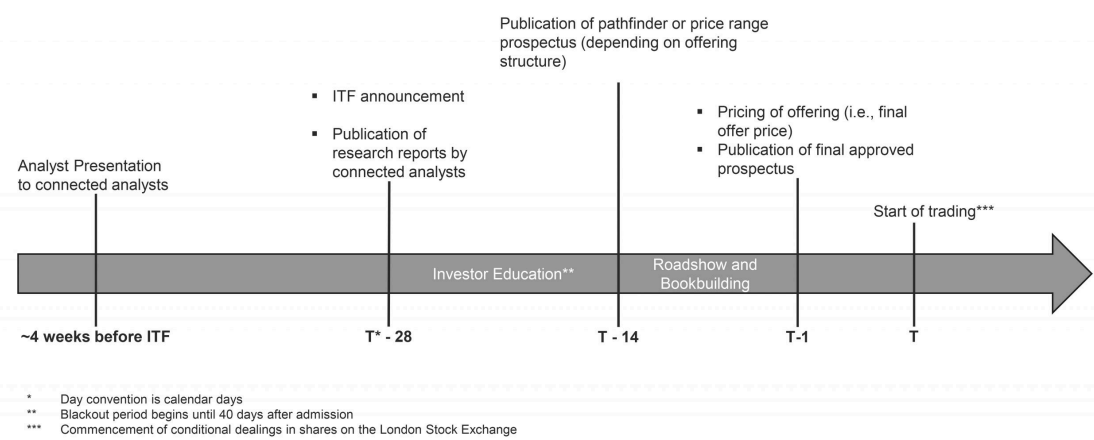

Following the implementation of the new FCA conduct rules under COBS 11.A and 12, prior to the publication of any pre-deal research reports from connected analysts a (i) FCA approved disclosure document must be published and (ii) unconnected analysts must have had access to the company's management. ${ }^{58}$ The FCA approved disclosure document can take the form of either the complete prospectus, which includes all offering related

54 The sponsor is typically an investment bank and is often the lead book-runner (see FCA Handbook (2020), Listing Rules, Section 8.3, <https://www.handbook.fca.org.uk/handbook>).

55 FCA Handbook (2020), COBS Conduct of Business Sourcebook (COBS),

$<$ https://www.handbook.fca.org.uk/handbook/COBS/>.

56 According to the London Stock Exchange (LSE), the Main Market is the "LSE's flagship market for established companies" (see < https://www.londonstockexchange.com/companiesand-advisors/main-market/main-market/home.htm>).

57 See supra Fn. 11.

58 See supra Fn. 55. 
information, or a registration statement that omits, among other offering related sections and post-IPO corporate details, the offer price range. ${ }^{59}$ In addition, to the extent that management has engaged with connected analysts (i.e., securities analysts from the same institutions as members of the syndicate banks participating in the IPO) through an analyst presentation or the like, the syndicate banks participating in the IPO must ensure that a range of unconnected analysts (i.e., securities analysts from financial institutions not participating in the IPO) have also had the opportunity to be in communication with the management team of the corporate issuer and receive the same information as the connected analysts. ${ }^{60}$

The FCA's amendments to the IPO process in the UK had a number of stated objectives ${ }^{61}$ In particular, the FCA aimed to "improve the range, quality and timeliness of information that is made available to market participants" ${ }^{162}$ by restoring the centrality of the issuer-published disclosure document as well as to "enhance the overall standards of conduct in the process" and facilitate the publication of unconnected IPO research.$^{63}$ Specifically, the FCA noted that the prospectus, the authoritative source of information on corporate issuers upon which liability attaches, was typically published quite late in the IPO process and, thus, too late (in the FCA's view) for investors to rely on it in a meaningful way during their investment decision-making process ${ }^{64}$ As a consequence, the FCA found that connected research was driving investor education and initial price discovery and viewed this as particularly problematic in light of potential bias and conflict of interest concerns between connected analysts and IPO syndicate members. ${ }^{65}$

Indeed, in their market analysis ahead of the recent COBS amendments, the FCA noted several potentially problematic practices among connected analysts in the UK. For example, connected analysts were meeting with advisors and corporate issuers alongside IPO pitches by the investment banking teams from the same financial institution. ${ }^{66}$ Furthermore, the FCA found limited variation in the financial forecasts among connected analysts in

\footnotetext{
$59 \quad$ See supra Fn. 55.

60 See supra Fn. 55.

61 See FCA Consultation Paper March 2017 supra Fn. 3, para 1.12. 2017), para 1.1.

63 FCA Policy Statement October 2017, para 1.1.

64 See FCA Discussion Paper April 2016 (Fn. 11).

65 See FCA Policy Statement October 2017 (Fn. 62), para 1.5.

66 FCA Consultation Paper March 2017 (Fn. 3), para 1.9.
}

62 UK Financial Conduct Authority, Policy Statement, Reforming the availability of information in the UK equity IPO process, October 2017 (hereinafter FCA Policy Statement October 
their published pre-deal research reports, arguably bringing into question the objectivity and independence of such connected pre-deal research reports. ${ }^{67}$ Interestingly, when evaluating conflict of interest and bias concerns of connected pre-deal research, the FCA also considered whether it would be appropriate to ban the use of connected research in UK IPOs. ${ }^{68}$ However, in light of the varying feedback received from various stakeholders, including indications from buy-side investors that pre-deal research reports are useful in certain respects (in particular in relation to the financial forecasts), the FCA was of the view that reforming the approach to the dissemination of information and creating an environment that promoted independent research in the context of IPOs would better achieve their policy goals. ${ }^{69}$ Thus, by bringing forward the publication of the FCA approved disclosure document and requiring corporate issuers to engage with independent securities analysts before any connected pre-deal research can be published, the FCA hoped to facilitate an increased level of purely independent research, improve the quality of the pre-deal research reports by creating a level playing field among securities analysts and increase the competitive dynamics between connected and unconnected securities analysts. ${ }^{70}$

\section{Analysts Presentations and Research Reports}

Following the implementation of the new FCA requirements under COBS 11.A through 12, companies now have two options by which to engage with connected and unconnected analysts. One option is for both connected and unconnected securities analysts to be invited to the analyst presentation held approximately four weeks prior to the intention to float (ITF) announcement. In terms of content and scope, the analyst presentation continues to follow the approach largely used prior to the recent FCA reforms, with the company's management presenting detailed information on the company and its strategy during a daylong session, accompanied by a lengthy presentation in the range of 100 to 150 slides. If this option is pursued, then research reports prepared by both connected and unconnected analysts may be published one day following the publication of the registration statement or prospectus.

\footnotetext{
$67 \quad$ FCA Consultation Paper March 2017 (Fn. 3), para 3.7

68 See FCA Consultation Paper March 2017 (Fn. 3), para 3.8 et seq.

69 See FCA Consultation Paper March 2017 (Fn. 3), para 3.10.

70 See FCA Policy Statement October 2017 (Fn. 62), para 2.8 et seq.
} 


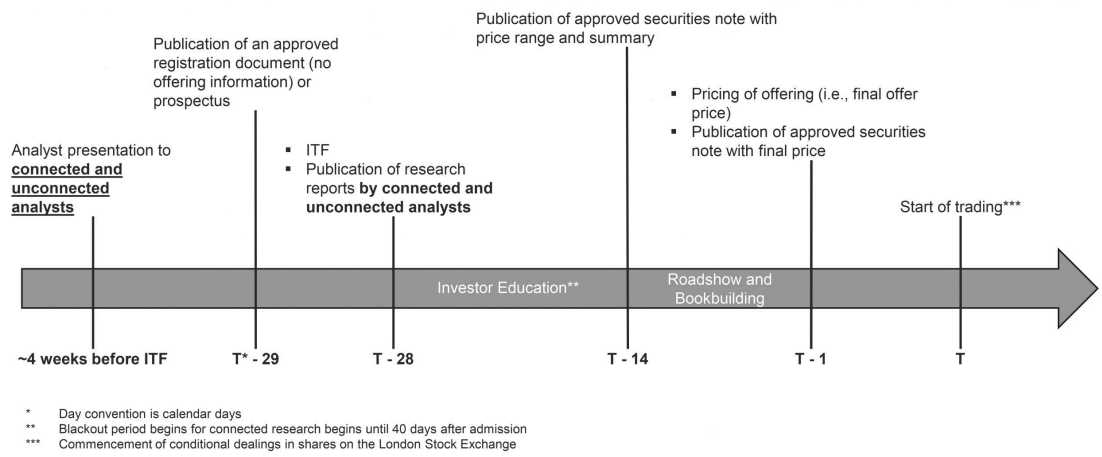

However, if the issuer decides to engage with unconnected analysts at a later stage (i.e., at a second briefing or, as a minimum, share all information given to connected analysts) and only connected analysts are invited to the analyst presentation, then research reports prepared by both connected and unconnected analysts may only be published seven days after the publication of the registration statement or prospectus.

In both scenarios, the publication of research reports is preceded by the ITF, the content of which has also evolved following the new FCA rules. Specifically, a new market practice is developing where companies first issue a press release accompanying the publication of the registration statement - the "potential ITF" or the "expectation of intention to float" (EITF). Companies who have listed under the new regime have included quite a bit of information in the EITF, similar to what is typically included in more traditional versions of ITFs in Europe. ${ }^{71}$ The ITF now follows on the date that research reports are published and can vary in substance depending on what was included in the EITF. $^{72}$

71 See e.g., Announcement of Intention to Publish a Registration Document and Potential Intention to Float on the London Stock Exchange, ReAssure Group plc, 7 June 2019, $<$ https://www.londonstockex change.com/exchange/news/market-news/market- newsdetail/other/14102332.html>.

72 See e.g., Bergman Mark S., UK IPO Reforms: One Year On, Paul, Weiss, Rifkind, Wharton \& Garrison LLP, 17 June 2019. 


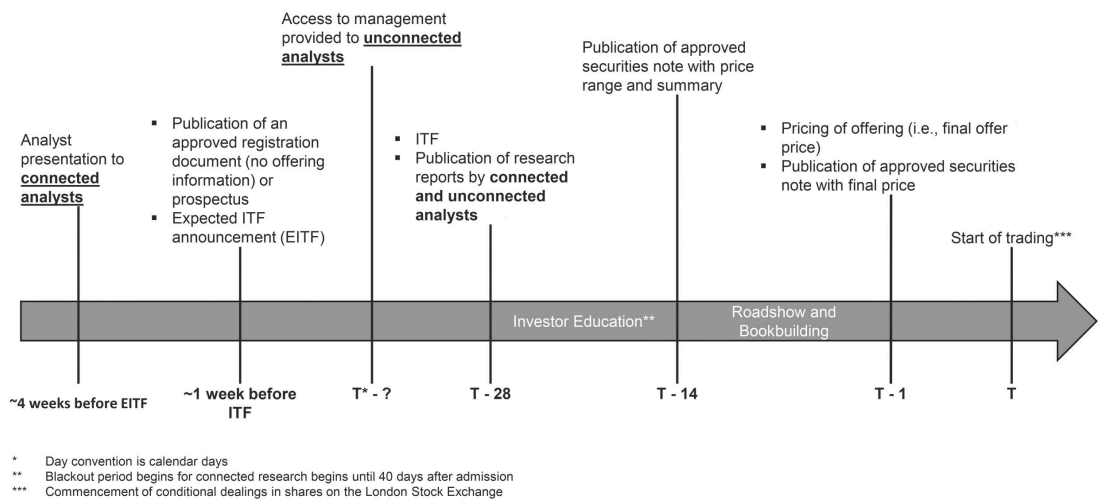

In either option, companies and their advisors have to enable unconnected analysts an opportunity to participate in the offering. If the first option is followed, the company with the assistance of its advisors will notify by email unconnected analysts who may be interested in receiving information about the prospective IPO. Industry organizations, such as the European Association of Independent Research Providers (Euro IRP), have begun preparing lists that include the contact details of securities analysts who have expressed interest in being contacted for such purposes. ${ }^{73}$ If unconnected analysts are permitted to attend the analyst presentation alongside connected analysts, then they should be afforded the same opportunities for asking questions, including at the session and afterwards via written format. ${ }^{74}$

If a company decides to follow the second option, then the issuer will typically include an invitation for unconnected analysts to contact the company to receive information on the IPO in its EITF announcement. To facilitate the process of onboarding unconnected analysts, the corporate issuer will include a portal on its website where such unconnected analysts can register their interest and the company and its advisors can evaluate the credentials of such securities analysts to ensure that they are a bona fide unconnected securities analysts before providing the relevant information. In addition to including

73 See e.g., European Association of Independent Research Providers (Euro IRP), $<$ https://euroirp.com/di rectory/pre-ipo/>.

74 See COBS 11A.1.4B (Fn. 55); see also Association for Financial Markets in Europe (AFME), UK IPO Re-form Q\&A in relation to COBS 11A, 20 December 2018. 
a notice on its EITF, the issuer will also circulate an email notification to unconnected securities analysts pursuant to lists prepared by industry associations such as Euro IRP. ${ }^{75}$

Once all bona fide independent securities analysts have been identified, they are either invited to an in-person meeting with the corporate issuer or, as has been more broadly adopted in recent offerings, provided online access (such as through NetRoadsow) to the analyst presentation and written transcripts of all question and answer sessions with the company's management. Depending on the company and the level of interest, the company may decide to provide unconnected securities analysts with an abbreviated presentation, an inperson Q\&A session or a conference call whereby such unconnected securities analysts can ask any additional questions they may have. In recent IPOs that have followed this option, the ITF and publication of pre-deal research reports has followed approximately seven to 12 days after the publication of the registration document and the EITF. ${ }^{76}$

In both scenarios, the practice of reviewing research reports remains as prior to the new $\mathrm{COB}$ rules. Specifically, only the research reports of connected securities analysts are reviewed and commented on for factual accuracy and compliance with applicable research guidelines by counsel and other advisors. While unconnected securities analysts are required to observe certain abbreviated research guidelines, ${ }^{77}$ their reports are not subject to review by counsel and other advisors for factual accuracy or compliance with such abbreviated research guidelines. Interestingly, unconnected securities analysts are not similarly restricted by blackout periods post- pre-deal research publications like other connected securities analysts. Thereby potentially providing early trading research by such securities analysts.

Following the implementation of the new regime, most companies have opted to publish a registration statement followed by a prospectus. ${ }^{78}$ Since one of the main goals of publishing pre-deal research reports accompanied by additional pilot fishing meetings is price discovery, it is not really surprising that most companies are opting for this approach where pricing and offering

\footnotetext{
75 See supra Fn. 73.

76 See supra Fn. 72.

77 See e.g., AFME and Euro IRP, UK Initial Public Offerings - Process in Relation to Proving Issuer Access for Unconnected Analysts (20 August 2018), <https://www.afme.eu/news/ press-releases/detail /afme-and-euro-irp-publish-guidance-on-how-unconnected-research-analysts-can-access-issuer-inform ation-in-uk-ipos>.

78 See Market Tracker Trend Report, Trends in UK Equity Capital Markets, Lexis PSL Corporate, Lexis Nexis, June 2019, pp. 14-18.
} 
related information can be furnished at a later stage, while business, risk factor and financial related information (i.e., key disclosure information that should inform investment decisions) is available earlier. In addition, in connection with these offerings the issuers and syndicate banks have opted to separate connected and unconnected securities analyst communication and exposure to management. ${ }^{79}$ Commentators have generally agreed that the decision to separately engage with connected securities analysts and unconnected securities analysts largely stems from concerns around confidentiality and limiting potential leaks about the offering. ${ }^{80}$ In addition, market commentators have observed rather moderate interest from unconnected securities analysts to participate in UK IPOs during the course of 2019.

\section{Hong Kong}

\section{Overview}

As in other international jurisdictions outside of the United States, pre-deal research reports have been a feature of Hong Kong IPOs for many years. ${ }^{81}$ However, like elsewhere, securities regulations in Hong Kong do not expressly address pre-deal research reports. As such, the topic has largely remained under the purview of Hong Kong's main financial regulator, the Securities and Futures Commission (SFC). As the main market regulator for securities in Hong Kong, it is their statutory duty to administer the Securities and Futures Ordinance ${ }^{82}$ and in furtherance of its statutory obligations it has also published, among other codes of conduct, the SFC Code of Conduct for Persons Licensed by or Registered with the Securities and Futures Commission (SFC Code of Conduct). ${ }^{83}$

In August 2005 and September 2006, the SFC published a consultation paper followed by their consultation conclusions, respectively, on possible reforms

79 See Market Tracker Trend Report, Trends in UK Equity Capital Markets, Lexis PSL Corporate, Lexis Nexis, June 2019, pp. 14-18.

80 See Market Tracker Trend Report, Trends in UK Equity Capital Markets, Lexis PSL Corporate, Lexis Nexis, June 2019, pp. 14-18.

81 Securities and Futures Commission, Consultation Paper on the Regulatory Framework for Pre-deal Research, Hong Kong, September 2010 (hereinafter SFC Consultation Paper September 2010), para 12.

82 Securities and Futures Ordinance, 1 April 2003.

83 Securities and Futures Commission, Code of Conduct for Persons Licensed by or Registered with the Securities and Futures Commission, Twenty-fourth edition, September 2019 (hereinafter SFC Code of Conduct). 
to modernize the prospectus regime in Hong Kong. ${ }^{84}$ As part of its review of the then current initial public offering regime in Hong Kong, the SFC specifically considered, among other matters, the practice of pre-deal research reports in Hong Kong IPOs. ${ }^{85}$ Their focus on pre-deal research reports largely stemmed from the SFC's two-fold concern of "inequality of information" between professional investors who receive such pre-deal research reports and other investors whose only source of information on a corporate issuer is the prospectus and "inaccurate information". ${ }^{86}$ In particular, the SFC noted the high incidence of "information contained in predeal research reports being reported on in the media in the lead-up to and during the offer period for IPOs"87 that was not similarly being included in the corporate issuer's own prospectus and thereby subverting the prospectus liability regimes. ${ }^{88}$ In order to address these concerns, the SFC had several initial proposals, including an outright ban on the publication of pre-deal research reports by securities analysts connected with the sponsor or underwriting syndicate. ${ }^{89}$ However, following "substantial" feedback from various stakeholders against banning pre-deal research reports ${ }^{90}$ the SFC acknowledged the role of pre-deal research reports in price discovery and decided not ban their publication, but rather shifted their focus to ensuring the independence and objectivity of securities analysts as well as equal and accurate distribution of information. ${ }^{91}$

Securities and Futures Commission, Consultation Paper on Possible Reforms to the Prospectus Regime in the Companies Ordinance, Hong Kong, August 2005 (hereinafter SFC Consultation Paper August 2005); Securities and Futures Commission, Consultation Conclusions on the Consultation Paper on Possible Reforms to the Prospectus Regime in the Companies Ordinance, Hong Kong, September 2006 (hereinafter SFC Consultation Conclusions September 2006).

85 SFC Consultation Paper August 2005 (Fn. 84), para 15, p. 10

86 SFC Consultation Conclusions September 2006 (Fn. 84), pp. 38-39.

87 Securities and Futures Commission, Press Release: Consultation Paper on Possible Reforms to the Prospectus Regime, Hong Kong, 29 August 2005, <https://sfc.hk/edistributionWeb/ gateway/EN/news-and-announcements/news/doc?refNo=05PR188>. Securities and Futures Commission, Press Release: Consultation Paper on Possible Reforms to the Prospectus Regime, Hong Kong, 29 August 2005, <https://sfc.hk/edistributionWeb/ gateway/EN/news-and-announcements/news/doc?refNo=05PR188>. SFC Consultation Paper August 2005 (Fn. 84), para 29.13, p. 46

91 SFC Consultation Conclusions September 2006 (Fn. 84), p. 39. 
The SFC then revisited the topic again in another consultation paper in 2010 with accompanying reforms coming into force in the fall of $2011 .^{92}$ Among other measures seeking to safeguard the independence and objectivity of securities analysts publishing pre-deal research reports, the SFC was again focused on the content of pre-deal research reports and tightened the prohibitions around securities analysts seeking or obtaining material non-public information about the corporate issuer, if such information is not reasonably expected to be included in the prospectus. The SFC specifically cited their concern that professional investors, who are the typical recipients of such predeal research reports, would benefit from additional material information that would not be included in the prospectus and, as such, also not available to other investors, in particular retail investors. ${ }^{93}$ As in 2005, the SFC was also concerned with pre-deal research reports potentially being used by corporate issuers as a means "to disseminate material information relating to an offer without formal prospectus liability". ${ }^{44}$ Interestingly, the SFC specifically declined to revisit whether pre-deal research reports should be prohibited in Hong Kong IPOs and rather proceeded with certain reforms to the SFC Code of Conduct. ${ }^{95}$

Under the current SFC Code of Conduct, among other requirements, regulated firms must have policies and control procedures in place to ensure that securities analysts are not (i) prejudiced by a firm's financial interests and business relationships ${ }^{96}$ or (ii) provided by the firm with any material information, including forward-looking information (whether qualitative or quantitative) concerning the listing applicant, if such information is not reasonably expected to be included in the prospectus or publicly available. ${ }^{97}$ In addition, securities analysts must refrain from seeking to obtain any such information from the listing applicant or its directors, employees or substantial shareholders, or any of their respective advisers. ${ }^{98}$ In determining whether information is "material", the SFC considers whether such information is material to an investor in forming "a valid and justifiable opinion

SFC Consultation Paper September 2010 supra Fn. 82; Securities and Futures Commission, Consultation Conclusions on the Regulatory Framework for Pre-deal Research, Hong Kong, June 2011 (hereinafter SFC Consultation Conclusions June 2011). SFC Consultation Paper September 2010 (Fn. 81), para. 7. SFC Consultation Paper September 2010 (Fn. 81), para. 7. 
of the shares and the financial condition and profitability of the company". ${ }^{99}$ Generally, notwithstanding information or views ascertained through a securities analyst's own due diligence on a corporate issuer, the SFC expects that a securities analyst should only use information that is reasonably expected to be included in the prospectus or that is publicly available. ${ }^{100}$ However, as noted earlier, one of the key benefits of pre-deal research reports is the securities analysts' financial forecasts derived from their financial modeling. In order to create financial models based on reasonable assumptions, securities analysts often require certain information from corporate issuers, such as the corporate issuer's view on the relevant industry trends and development, which will not likely be included in the prospectus. Indeed, several stakeholders raised this concern in their responses to the consultation paper in 2010. ${ }^{101}$ While, the SFC refined the wording of the proposed rule change, they declined to provide any further guidance on what type of forward-looking information would or would not be considered material. ${ }^{102}$ However, the SFC noted that as part of the listing application, corporate issuers are required under the Stock Exchange of Hong Kong (HKEx) Listing Rules to submit their profit forecasts and cash flow forecasts to the HKEx. ${ }^{103}$ Since such information is typically not also included in the prospectus, the SFC vaguely suggested that this should provide securities analyst with some guidance on what types of forward-looking information would arguably not fall within the definition of "material". ${ }^{104}$

\section{Analysts Presentations and Research Reports}

For companies pursuing an IPO on the HKEx, offerings generally follow the below timeline.

\footnotetext{
99 SFC Consultation Conclusions June 2011 (Fn. 92), para. 33.

100 SFC Consultation Conclusions June 2011 (Fn. 92), para. 31 et seq.

101 SFC Consultation Conclusions June 2011 (Fn. 92), para. 43.

102 SFC Consultation Conclusions June 2011 (Fn. 92), para. 47 et seq.

103 SFC Consultation Conclusions June 2011 (Fn. 92), para. 39.

104 SFC Consultation Conclusions June 2011 (Fn. 92), para. 39.
} 


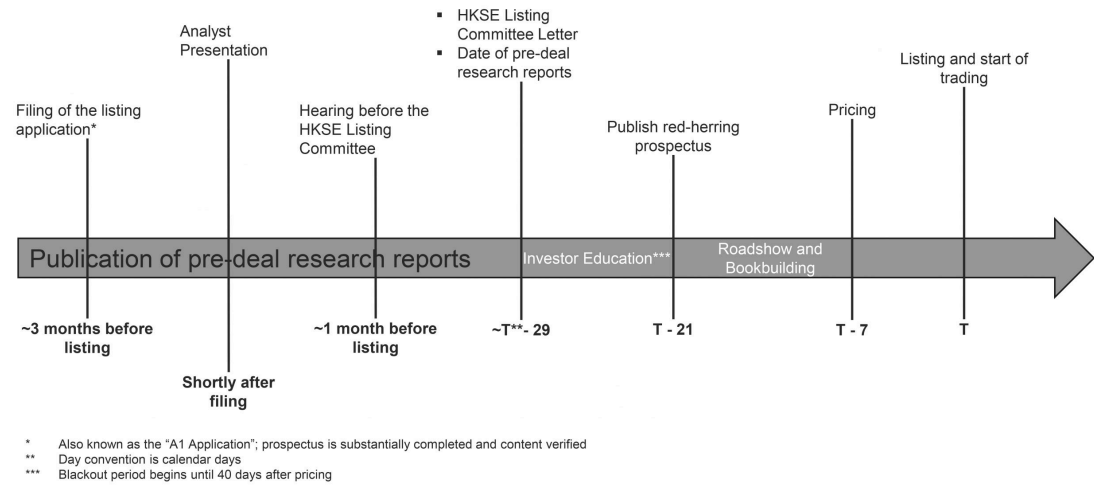

As illustrated above, the analyst presentation usually occurs after the submission of the A1 application to the HKEx and the subsequent publication of the application proof (i.e., draft disclosure document, which excludes offering related information) on the HKEx's website. ${ }^{105}$ According to the HKEx Listing Rules, the application proof must be sufficiently complete and at this stage the sponsor (e.g., the global coordinator(s)) should come to a reasonable view that the information contained in the application proof is substantially complete, except for information that by its nature can only be addressed or known at a later time (e.g., pricing information and subsequent business developments). ${ }^{106}$ To the extent that the listing department finds the application or the application proof incomplete, the HKEx listing department will return the application, and the corporate issuer will not be permitted to re-submit its listing application for eight weeks. ${ }^{107}$ In light of the significant delay to the overall transaction timetable if a listing application is returned, the application proof must be significantly advanced upon filing. Generally, the analyst presentation is held two to three weeks after the acceptance of the listing application (but can be as early as one week after).

As noted above, once the listing application has been accepted, the HKEx publishes the application proof (which includes the current version of the disclosure document) on its website, making it publicly available. Securities analysts are encouraged to study the application proof and to submit

Rules Governing the Listing of Securities on the Stock Exchange of Hong Kong Limited Equity Securities, Chapter 9, para 9.08, 30 September 2019 (update no. 127) (hereinafter HKEx Listing Rules). 
questions to the corporate issuer in advance of the analyst presentation. ${ }^{108}$ In light of the advanced disclosure document that is available and strict regulations around the provision of any additional material information that is not reasonably expected to be included in the prospectus, analyst presentations themselves in Hong Kong tend to be significantly shorter than those delivered in Europe. Analyst presentations typically last a few hours, with presentations averaging around 50 slides, as compared to the full day (if not multi-day presentations) and over 100-slide presentations customarily delivered in Europe.

Furthermore, in light of liability concerns, corporate issuers and their advisors are encouraged to prepare and strictly follow an analyst presentation script, which is reviewed in advance by counsel, to ensure that no material information is shared with securities analysts that is not included in the application proof or publicly available. ${ }^{109}$ To further ensure that no such information is communicated to securities analysts during the analyst presentation, both the corporate issuer's and syndicate's counsel chaperone the analyst presentation. ${ }^{110}$ Following the delivery of the analyst presentation, two to three drafts of the pre-deal research reports are reviewed by the syndicate's counsel and the sponsor(s) for legend requirements, factual consistency with the prospectus and to further safeguard that no additional material information has been provided and included in the research reports that is not public or included in the application proof. ${ }^{111}$

Interestingly, neither the corporate issuer nor their counsel review the research reports for compliance with the legend requirements, factual consistency with the prospectus and to further safeguard that no additional material information has been provided and included in the research reports that is not public or included in the application proof. There is no specific rule or regulation prescribing this, but the practice has evolved to preserve the integrity and independence of the published research reports through the further separation of the securities analysts from the corporate issuer.

\footnotetext{
108 See Asia Securities Industry \& Financial Markets Association (ASIFMA), Pre-deal Research Addenda for the Hong Kong IPO process, August 2017, p. 8 (hereinafter ASIFMA Hong Kong IPO Process). See e.g., ASIFMA, Pre-deal Research Addenda for the Hong Kong IPO process (powerpoint presentation, October 2017, slide 3, <https://www.asifma.org/resource/pre-deal-research-addenda-for-the-hong-kong-ipo-process/>.

110 See e.g., ASIFMA Hong Kong IPO Process (Fn. 108), p. 24.

111 See e.g., ASIFMA Hong Kong IPO Process (Fn. 108), p. 35.
} 
Distribution of the research reports in Hong Kong is only permitted during the period after the listing application has passed the hearing of the listing committee of the HKEx. ${ }^{12}$ If the application is approved or approved in principle, the pre-marketing or investor education stage of the IPO can commence, including with the publication of the research reports. These hearings usually occur on a Thursday and are typically followed by a posthearing letter setting out the listing committee's decision on the following Friday. Thus, research reports are published at the earliest on the Friday once the listing committee's positive feedback has been received or at the latest the following Monday, which is essentially one week prior to the launch of the IPO (or printing of the red-herring prospectus).

\section{Switzerland $d^{113}$}

\section{Overview}

Unlike in the United States, the United Kingdom and Hong Kong, Switzerland's regulation of securities analysts and pre-deal research reports has largely been market-driven and most significantly influenced by the international scope of Switzerland's largest banks, which have more or less adopted and imputed certain regulatory requirements of other significant foreign jurisdictions concerning securities analysts into the approach applied in Switzerland. ${ }^{114}$

Despite the absence of the direct attention of Swiss financial regulators, the Swiss Bankers Association, an industry association, has published the "Directive on the Independence of Financial Research".15 In this directive, the Swiss Bankers Association outlines certain key principles for the internal organization and external relationships for financial institutions that provide investment research. Generally, to safeguard the independence of such securities analysts from any investment banking activities, certain structural and organizational divisions should be implemented, including through the establishment of Chinese walls and specific duties of the compliance unit to

\footnotetext{
112 HKEx Listing Rules (Fn. 105), para. 9.

113 This section describes the typical IPO process in Switzerland as of November 2019 and does not take into account the new prospectus regime that came into force pursuant to the Financial Services Act of 15 June 2018 and the Financial Services Ordinance of 6 November 2019 as well on 1 January 2020 (subject to the timelines provided for therein).

114 See e.g., Chinese walls and control rooms.

115 Swiss Bankers Association, Directives on the Independence of Financial Research, January 2008 (update January 2018) (hereinafter SBA Financial Research Directive).
} 
mediate such relationships. ${ }^{116}$ In addition, the directive stipulates that, subject to exceptions permitted by a financial institution's compliance unit, securities analysts from a financial institution that has been involved in an IPO may not publish any new reports or new recommendations for a period of 40 calendar days following the first day of trading. ${ }^{117}$ Unlike FINRA or the SEC in the United States, the FCA in the United Kingdom and SFC in Hong Kong, the Swiss Bankers Association is not mandated with any enforcement authority.

\section{Analysts Presentations and Research Reports ${ }^{118}$}

In Switzerland, IPO timelines more or less follow the approach indicated below.

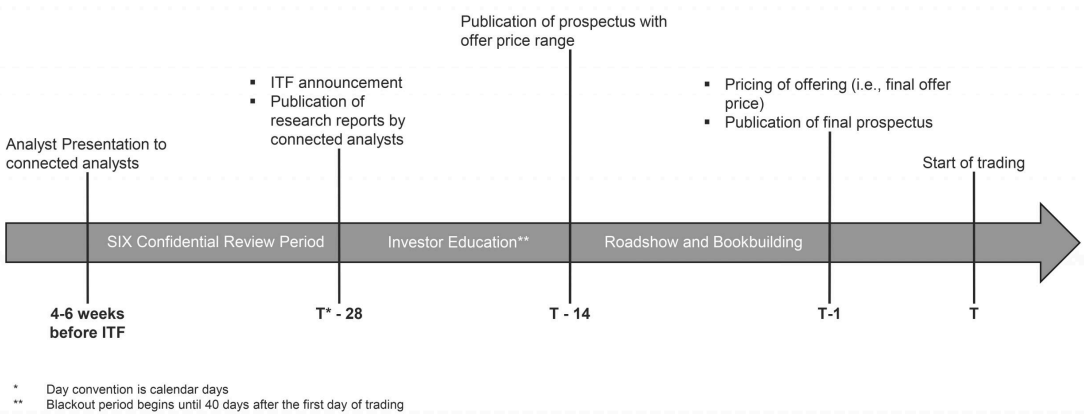

In Switzerland, analyst presentations usually occur four to six weeks ahead of a corporate issuer's intention to float announcement. The presentations can begin with a dinner before the actual presentation day where securities analysts are provided with an initial introduction to the company. Whether or not securities analysts participate in the initial introduction to a corporate issuer, all securities analysts from members of the financial syndicate involved in the IPO will participate in a daylong presentation, where the corporate issuer's management presents 100 to 150 slides on the company's investment highlights, its strategies, main business or product lines and financial performance over the last three years followed by a tour of the company's headquarters or manufacturing facility. While counsel to both the corporate

\footnotetext{
116 SBA Financial Research Directive, para. 8.

117 SBA Financial Research Directive, para. 26.

118 This section describes the approach in Switzerland prior to the entry into force of Financial Services Act of 15 June 2018 and its implementing ordinance, the Financial Services Ordinance.
} 
issuer and the managers closely review and comment on the content of the analyst presentation to ensure consistency with the prospectus (which is being advanced in parallel), they generally do not attend the analyst presentation. However, management is advised that any additional commentary or "voice-overs" should not extend beyond the content of the analyst presentation or the prospectus.

Following the analyst presentation, securities analysts are then provided with an opportunity to submit questions to the corporate issuer, which will be followed by a call and responses in written format. In Switzerland, there is a mixed practice on whether securities analysts receive a copy of the prospectus (or sections thereof) to assist with their preparation of their pre-deal research reports. The decision on whether to share the draft of the prospectus (or sections thereof) with securities analysts is usually subject to how advanced the various work streams are at this stage in the IPO, including the availability of the audited consolidated financial statements.

For companies seeking a listing on the SIX Swiss Exchange Ltd (Switzerland's main equity exchange), issuers must submit their listing application 20 trading days ahead of the start of the book-building process to SIX Exchange Regulation Ltd. ${ }^{119}$ As part of the listing application, a draft of the prospectus is submitted, but it is treated on a confidential basis and is not publicly disclosed. In addition, generally subsequent drafts of the prospectus can be submitted to the SIX Exchange Regulation without negatively impacting the review and approval timeline.

Approximately two weeks prior to the planned date of the intention to float announcement, analysts submit redacted drafts (i.e., with valuation information removed) of their pre-deal research reports to the issuer, the joint bookrunners and their respective counsel for review of compliance with legend requirements and consistency with the information provided in the analyst presentation, including factual accuracy. Typically, there are two rounds of review of draft pre-deal research reports ahead of their publication on the date of the intention to float announcement. Notably, only once the IPO is officially launched and the book-building process commences is the corporate issuer's prospectus finally available.

The Financial Services Act (FinSA) and the Financial Services Ordinance (FinSO), which includes important prospectus reforms, entered into force on 
1 January $2020{ }^{120}$ There are several significant changes to the equity offering process in Switzerland that will follow pursuant to FinSA and FinSo, most significantly being the new prospectus rules for public offerings and admission to trading. These new prospectus rules for public offerings and admission to trading will to enter into force six months after the first review body is licensed by the Swiss Financial Market Supervisory Authority (FINMA). ${ }^{121}$ Pursuant to the new legislation, subject to certain exemptions, all public offering prospectuses will need to be reviewed and approved by the approval authority or reviewing body with respect to completeness, coherence and comprehensibility before the publication of the offering or the admission to trading on a Swiss trading platform. The prospectus approval process is expected to be split into: (i) an approval process (i.e., by the reviewing body); and (ii) an admission to trading process (i.e., by the exchange admission body, such as SIX Exchange Regulation). Importantly, first-time issuers will be required to submit their prospectus for approval at least 20 calendar days (all other issuers at least 10 calendar days) before the publication of the offering or the admission to trading on a Swiss trading platform. In light of the need to submit a "complete" prospectus under FinSA and FinSO to initiate the approval process there might be significant tension to advance both the analyst presentation and the prospectus in parallel. In light of this, timelines for Swiss IPOs will need to be reconsidered to ensure that all the documents are ready by the various deal milestones.

\footnotetext{
120 Financial Services Act of 15 June 2018 (as of 1 January 2020); Financial Services Ordinance of 6 November 2019 (as of 1 January 2020).

121 As of 6 April 2020, FINMA has not provided a license to a review body in Switzerland.
} 


\section{Comerative Overview}

\begin{tabular}{|c|c|c|c|c|}
\hline & United States & United Kingdom & Hong Kong & Switzerland \\
\hline $\begin{array}{l}\text { Background to current } \\
\text { regulatory approach }\end{array}$ & $\begin{array}{l}\text { Reactive; direct response to } \\
\text { Dot-Com Bubble (2003) } \\
\text { - conflict of interest; bias } \\
\text { - publication of fraudulent } \\
\text { reports; lack of fair } \\
\text { dealing and good faith, } \\
\text { etc. } \\
\text { - JOBS Act } 2012\end{array}$ & $\begin{array}{l}\text { Mix of reactive and proactive } \\
\text { (2018) } \\
\text { - conflict of interest; bias } \\
\text { - access to prospectus } \\
\text { - lack of competition } \\
\text { among analysts } \\
\text { - inefficiency of price } \\
\text { discovery }\end{array}$ & $\begin{array}{l}\text { Mix of reactive and proactive } \\
\text { (2005/2011) } \\
\text { - conflict of interest; bias } \\
\text { - inequality of information } \\
\text { - inaccurate information } \\
\text { - no material information to } \\
\text { securities analysts not in } \\
\text { prospectus or public }\end{array}$ & $\begin{array}{l}\text { Market-driven approach; } \\
\text { Swiss Bankers Association } \\
\text { Directive }\end{array}$ \\
\hline Current approach & $\begin{array}{l}\text { Analyst Day } \\
\text { (ca. }+100 \text { slides) } \\
\text { (Chaperoned) analyst day, } \\
\text { diligence sessions and Q\&A } \\
\text { sessions } \\
\text { Financial model (detailed } \\
\text { projections) }\end{array}$ & $\begin{array}{l}\begin{array}{l}\text { Analyst Presentation } \\
\text { (ca. }+100 \text { slides) }\end{array} \\
\text { Q\&A session } \\
\text { Written diligence questions } \\
\text { (with a chaperoned call) }\end{array}$ & $\begin{array}{l}\text { Analyst Presentation } \\
\text { (ca. } 50 \text { slides) } \\
\text { Chaperoned analyst } \\
\text { presentation }\end{array}$ & $\begin{array}{l}\text { Analyst Presentation } \\
\text { (ca. }+100 \text { slides) } \\
\text { Q\&A session } \\
\text { Written diligence questions } \\
\text { (with a chaperoned call) }\end{array}$ \\
\hline $\begin{array}{l}\text { Publication of (pre-deal) } \\
\text { research reports }\end{array}$ & $\begin{array}{l}\text { 1. Pricing of IPO and } \\
\text { registration statement } \\
\text { effective } \\
\text { 2. } 25 \text { days after pricing of } \\
\text { IPO } \\
\\
\text { *Communication with sales } \\
\text { team and certain investors } \\
\text { prior to and after launch }\end{array}$ & $\begin{array}{l}\text { 1. Approved registration } \\
\text { stmt or prospectus } \\
\text { available }\end{array}$ & $\begin{array}{l}\text { 1. Prospectus filed with } \\
\text { exchange } \\
\text { 2. Listing approved } \\
\text { 3. ca. } 7 \text { days before } \\
\text { printing of red-herring } \\
\text { (price range) prospectus }\end{array}$ & $\begin{array}{l}\text { 1. ITF } \\
\text { 2. } 14 \text { days before printing of } \\
\text { price range prospectus }\end{array}$ \\
\hline $\begin{array}{l}\text { Review of research } \\
\text { reports }\end{array}$ & Not relevant & $\begin{array}{l}\text { Yes, redacted; all parties, } \\
\text { but largely with issuer's } \\
\text { counsel } \\
\text { "connected analysts only }\end{array}$ & $\begin{array}{l}\text { Yes, redacted (if applicable); } \\
\text { only advisors and advisors' } \\
\text { counsel }\end{array}$ & $\begin{array}{l}\text { Yes, redacted; all parties, but } \\
\text { largely with issuer's counsel }\end{array}$ \\
\hline $\begin{array}{l}\text { Availability of a } \\
\text { disclosure document } \\
\text { (e.g., prospectus or } \\
\text { equivalent) }\end{array}$ & $\begin{array}{l}\text { Public SEC filings available } \\
\text { around Analyst Day; } \\
\text { effective registration } \\
\text { statement is available before } \\
\text { publication of research } \\
\text { reports }\end{array}$ & $\begin{array}{l}\text { Registration document or } \\
\text { prospectus is available } \\
\text { depending on approach ( } 1 \text { to } \\
7 \text { days ahead of publication } \\
\text { of pre-deal research reports) }\end{array}$ & $\begin{array}{l}\text { Listing application is filed } \\
\text { and available on exchange } \\
\text { website before analyst } \\
\text { presentation (and well before } \\
\text { publication of pre-deal } \\
\text { research reports) }\end{array}$ & $\begin{array}{l}\text { No form of disclosure } \\
\text { document available at } \\
\text { publication of pre-deal } \\
\text { research reports } \\
\text { *all recipients of pre-deal } \\
\text { research reports should } \\
\text { receive the prospectus }\end{array}$ \\
\hline
\end{tabular}

\section{Concluding Remarks}

From a simple "lawyer's" perspective, the basic approach to marketing an IPO would be the prospectus where initial investor education and interest in the offering is piqued by management presentations after launch (i.e., roadshow presentations). ${ }^{122}$ However, deal experience and feedback from various IPO advisors and investment banks suggest that the reality and economics of IPOs 
make such a straightforward approach less conducive for a successful IPO. Specifically, there are significant execution risks for an IPO absent pre-deal investor education (of which pre-deal research reports form a large part).

Specifically, investor feedback and intelligence gathered through the pre-deal investor education process assists advisors in developing the most appropriate marketing strategy for a corporate issuer, including (i) the presentation and positioning of the issuer in the respective market, (ii) commentary on the issuer's strategy and (iii) (perhaps most importantly) a realistic IPO price range. Indeed, pre-deal investor education can be an important factor to a successful IPO because if investment demand is too low (due to the price range being too high) or there are doubts regarding the business strategy or growth prospects that were not previously taken into account, the IPO could fail or the corporate issuer's share price could drop dramatically after going public. Both are disastrous outcomes for a growing company.

But what about the role of pre-deal research reports specifically in the predeal investor education process? International financial regulators have responded to different market practices and implemented different regimes to address their specific concerns, but why? Given that pre-deal research reports are only distributed to sophisticated institutional investors, one has to ask whether such investors really need pre-deal research reports and why they cannot develop this information themselves. Interestingly, when the topic was debated in Hong Kong and the UK, both the Hong Kong and UK regulators proposed banning pre-deal research reports altogether. ${ }^{123}$ Indeed, the practice effectively does not form part of the pre-deal investor education process in the United States. Furthermore, market studies revealed that such sophisticated institutional investors actually acknowledge that "the connected research produced during IPOs is at heightened risk of bias". ${ }^{124}$ However, and perhaps most revealing, these same investors, also stated that they should similarly "be able to make their own allowances for these potential biases and to exercise their own judgements". ${ }^{125}$ Thus, institutional investors, nonetheless, find pre-deal research reports useful in providing helpful interpretative color on the information contained within the prospectus and few felt an outright ban on connected pre-deal research was merited. ${ }^{126}$

See FCA Consultation Paper March 2017 (Fn. 3), para 3.8 et seq; SFC Consultation Conclusions September 2006, supra Fn. 85, p. 35. 
In essence, the three of the most widely cited benefits of pre-deal research reports that has kept the practice alive across many jurisdictions outside of the United States are: (i) investor education, (ii) independent assessment and (iii) efficient price discovery. In relation to investor education, pre-deal research reports have been identified as an important aspect for bringing initial attention to investors in smaller IPOs or for companies in niche industries where investors do not know much about the corporate issuer or its industry. ${ }^{127}$ Pre-deal research reports have also been acknowledged as useful in providing an independent assessment of a corporate issuer. Assuming that effective controls and conflict of interest measures are in place, securities analysts specialized in a certain industry or geography are theoretically very well placed to provide investors with an independent assessment of a corporate issuer as compared with peers in their specific geography or industry sector and provide detailed insight into the industry. Finally, during the process of price discovery ${ }^{128}$ in an IPO, the underwriting syndicate will try to determine the "price per share" via a number of different methods as well as evaluate a number of factors, including investor opinion, interest and risk appetite. Through investor education, such price discovery arguably becomes more efficient in light of the increased information available to investors during the time period leading up to the launch of the IPO enabling them to form realistic opinions about the potential value of an IPO candidate's shares.

In short, while international financial regulators have taken markedly different approach to pre-deal research reports, the general international consensus seems to suggest that such pre-deal research reports will remain a fixture of IPOs outside of the United States for the foreseeable future.

128 Price discovery is the overall process of gauging the appropriate share price range for a corporate issuer both pre-IPO and once they are listed. 


\title{
LIBOR Transition for Derivatives Transactions
}

\author{
Olivier Favre
}

\section{Content}

I. Introduction...……………………………………………………………………………..6

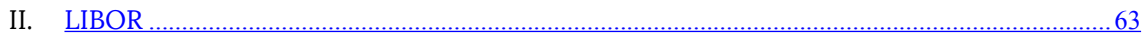

1. LIBOR Methodology ………………………………………………………………....6 63

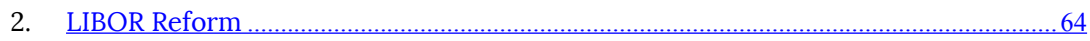

3. EU Benchmark legislation …………………………………………………………………...66

III. Other IBORs that are expected to be maintained...…………………………………………...67

1. EURIBOR ……………………………………………………………………....67

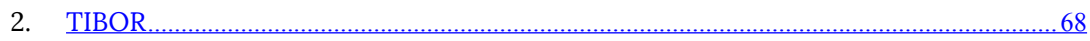

IV. Risk-free Rates as alternatives to LIBOR rates ………………………………………....68

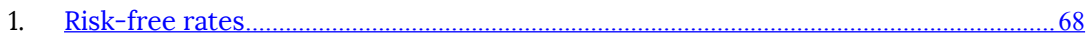

2. Compounding of alternative risk-free rates ............................................................71

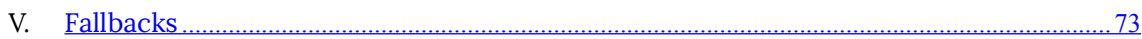

1. $\quad$ Need for the agreement of fallbacks …………………………………………….....73

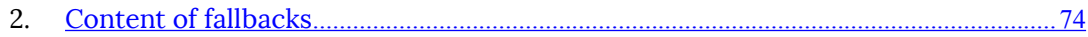

3. Fallback clauses of Derivatives Transactions ………………………………………… 75

a) Derivatives Documentation...………………………………………………………….. 75

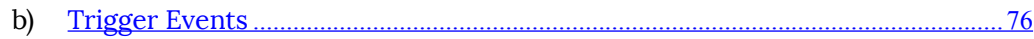

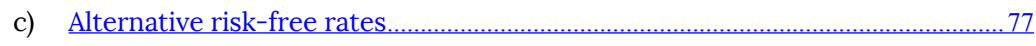

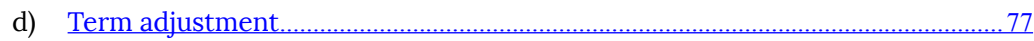

e) Spread adjustment …………………………………………………………………. 78

f) Publication of adjusted risk-free rates ………………………………………….. 79

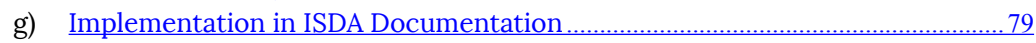

aa) Supplement to 2006 ISDA Definitions....……………………………………....79

bb) ISDA Protocol ………………………………………………………………. 79

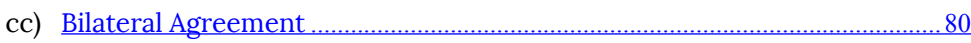

h) Implementation for local Swiss Documentation ………………………………... 80

aa) Protocol vs. bilateral agreement …………………………………………....80

bb) Benchmark Amendment Agreement ............................................................81

VI. Interrelation of derivatives with loans.............................................................................. 81

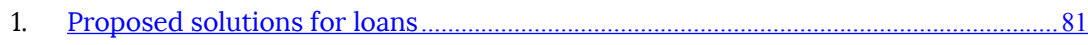

2. Basis risk …………………………………………………………………………………...... 82

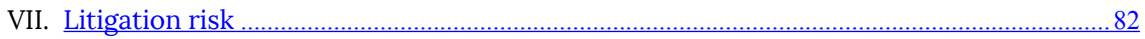

1. Failing to agree on Fallbacks for legacy transactions ………………………………...8

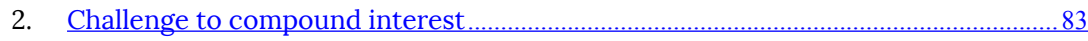


Literature

\section{Introduction}

The fate of the LIBOR benchmarks was sealed when Andrew Bailey, the chairman of the FCA at the time, stated in a speech on 27 July 2017 that "it would no longer be necessary for the FCA to persuade, or compel, banks to submit to LIBOR" by the end of 2021. ${ }^{1}$ This view was mirrored in the US, when CFTC Chairman Christopher Giancarlo said on 12 July 2018 that "The discontinuation of LIBOR is not a possibility. It is a certainty. We must anticipate it, we must accommodate it and we must adapt to it."

The UK authorities have - since 2017 - maintained their position that LIBOR should cease to exist at the end of 2021 and a transition to alternative risk-free rates should be completed by such date. ${ }^{3}$

The end of the London Interbank Offered Rate (LIBOR) is therefore approaching. Nevertheless, LIBOR benchmarks are still widely used for products traded today, in particular in the interest rate derivatives and loan markets and for floating rate notes. Taking into account all products referring to LIBOR benchmarks in a form or another, the affected transactions amount to approximately USD 400 trillion in nominal value. ${ }^{4}$ A large part of these transactions are interest rate derivatives (e.g. interest rates swaps, futures, options or cross-currency swaps).

This article discusses what alternative interest rate benchmarks may be used instead of LIBOR rates in the derivatives market and how to proceed with regard to transactions referring to LIBOR rates that have a maturity beyond the end of LIBOR.

\footnotetext{
Available on $<$ https://www.fca.org.uk/news/speeches/the-future-of-libor>.

2 Available on

$<$ https://www.cftc.gov/PressRoom/SpeechesTestimony/giancarlostatement071218>.

3 See Financial Stability Report of the Bank of England of December 2019, available on $<$ https://www.b ankofengland.co.uk/-/media/boe/files/financial-stability-report/2019/ december-2019.pdf>.

4 The estimation is calculated across the five major currencies, see SCHRIMPF/SuSHKO, Beyond LIBOR, 29, available on <https://www.bis.org/publ/qtrpdf/r_qt1903e.pdf>.
} 


\section{LIBOR}

\section{LIBOR Methodology}

LIBOR is currently administered by ICE Benchmark Administration Ltd. (IBA) $)^{5}$ and available in five currencies (USD, GBP, CHF, JPY and EUR) and seven maturities (overnight, one week, one month, two months, three months, six months, and twelve months), resulting in 35 values published on each London business day. ${ }^{6}$

The LIBOR methodology is designed to produce an average interest rate at which large, leading and internationally active banks are willing to lend money to each other on the wholesale, unsecured funding market. LIBOR is determined as a result of inputs by panel banks as answers to the question at what interest rate they are willing to lend each other unsecured money. The question has changed slightly over time. Until 1998, the question was: "At what rate do you think interbank term deposits will be offered by one prime bank to another prime bank for a reasonable market size today at 11 am?", i.e., it was a purely hypothetical question for hypothetical transactions between hypothetical parties. In 1998, the question was updated to: "At what rate could you borrow funds, were you to do so by asking for and then accepting interbank offers in a reasonable market size just prior to $11 \mathrm{am}$ ?", i.e., it is determined on the basis of a hypothetical transaction by the submitting panel bank.

The number of contributing LIBOR panel banks varies depending on the currencies: 16 panel banks are contributing as regards the USD and GBP benchmarks, 15 panel banks are contributing to the EUR LIBOR, 12 panel banks contribute to the JPY LIBOR and 11 panel banks contribute to the CHF LIBOR. The methodology is a "trimmed average" in the sense that the received submissions for each currency and tenor pair are ranked by IBA and trimmed by the exclusion of the upper and lower quartiles to remove outliers. The relevant LIBOR rate is then calculated as the arithmetic mean of the remaining submissions, rounded to five decimal places. Each submission by a panel bank carries an equal weight, subject to the trimming. ${ }^{7}$ The 35 LIBOR values are published at 11:55 a.m. (GMT) on each London business day.

The discretion that banks may use with this method made it susceptible to errors. From about 2003 onwards, submissions by panel banks have been

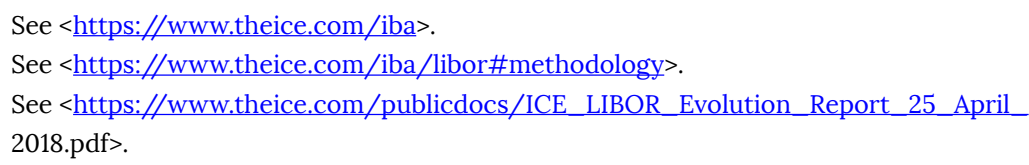

See $<$ https://www.theice.com/iba $>$.

See $<$ https://www.theice.com/iba/libor\#methodology $>$.

See $<$ https://www.theice.com/publicdocs/ICE LIBOR Evolution Report 25 April 2018.pdf>. 
subject to manipulations, which resulted in sanctions against some of the panel banks and even, in some cases, in criminal proceedings against persons involved.

A further weakness of the method became apparent in the financial crisis from 2009 onwards. With the credit crunch, it became increasingly difficult to borrow money in the interbank market with the result that the submissions by panel banks are reflecting to a lesser extent real transactions, which they are meant to represent.

\section{LIBOR Reform}

In 2014, the FSB carried out an analysis and recommended that the LIBOR and other "IBOR" benchmarks determined on the basis of similar methodologies (such as the EURIBOR and the TIBOR) should be reformed. ${ }^{8}$

Also, the Official Sector Steering Group (OSSG) was set up as a body to oversee the reform and to identify alternative, risk-free rates (RFRs) that can be used in the future as an alternative to the IBOR benchmarks.

As regards the LIBOR, the IBA meanwhile reformed the LIBOR methodology by introducing a waterfall to replace the previous LIBOR submission question. With such new methodology, LIBOR is defined as "a wholesale funding rate anchored in LIBOR panel banks' unsecured wholesale transactions to the greatest extent possible, with a waterfall to enable a rate to be published in all market circumstances". ${ }^{9}$

According to such methodology, LIBOR will continue to be determined on the basis of submissions by panel banks, but the inputs by panel banks must be made in the following order of priority:

level 1: where a panel bank has sufficient eligible transactions (i.e., unsecured deposits, primary issuances of commercial paper and certificates of deposit), a volume weighted average price (VWAP) of such eligible transactions, with a higher weighting for transactions booked closer to 11:00 am London time;

level 2: where a panel bank has insufficient eligible transactions to make a level 1 submission, it will seek to make a submission based on transactionderived data, including time-weighted historical eligible transactions adjusted for market movements and linear interpolation;

\footnotetext{
8 See FSB, 2014 Report.

9 See <https://www.theice.com/publicdocs/ICE LIBOR Evolution Report 25 April 2018.pdf>.
} 
level 3: where a panel bank has insufficient eligible transactions or transaction-derived data to make a level 1 or a level 2 submission, it will submit the rate at which it could fund itself at 11:00 am London time with reference to the unsecured, wholesale funding market. Each Panel Bank agrees its defined level 3 submission methodology with IBA, basing its rate on transactions, related market instruments, broker quotes and other market observations.

The trimmed arithmetic mean calculation methodology used to calculate LIBOR as it has been published so far will not change for LIBOR calculated using submissions made in accordance with the new waterfall methodology. ${ }^{10}$

On 1 April 2019, the IBA announced that it completed the transition to the new waterfall methodology. ${ }^{11}$ As of February 2020 , about $60 \%$ of the USD and GBP submissions for the overnight rates were based on level 1 determinations. For the other tenors of the USD and GBP rates, the share of level 1 determinations was below $10 \%$, but such determinations were in part made on the basis of level 2 data. For EUR, only overnight rates were determined on the basis of level 1 data with a share of approximately $30 \%$. For the tenors between 1 month and 12 months, level 2 determinations reached a level of approximately $5 \%$ to $10 \%$. For CHF and JPY, the determinations were entirely based on level 3 determinations. ${ }^{12}$

Despite these efforts, a large part of the determinations are based on markets that are not active and LIBOR is still dependent on expert judgment. In the view of the leading regulators, this is a fundamental flaw in the model, which is not sustainable and has no prospect of changing. ${ }^{13}$ Until the end of 2021, panel banks are expected to adhere to a voluntary agreement to continue to make submissions to LIBOR.

The FCA expects departures by the panel banks from the LIBOR submissions after the end of 2021. However, we do not know how the end of LIBOR will look like. It is quite possible that there will be a phasing-out with individual panel banks withdrawing from the submission process at different times. This raises the question at what point exactly LIBOR loses its representative effect

10 See $<$ https://www.theice.com/publicdocs/ICE_LIBOR_Evolution_Report_25_April_ 2018.pdf $>$.

11 See $<$ https://ir.theice.com/press/press-releases/all-categories/2019/04-01-2019130225158>.

12 See the relevant data on $<$ https://www.theice.com/publicdocs/ICE_LIBOR_Weekly_Report_ - 10 Feb_ 2020_-_14_Feb_2020.pdf>.

13 See <https://www.bankofengland.co.uk/-/media/boe/files/financial-stability-report/ 2019/december-2019.pdf>. 
and whether there should be switch to alternative benchmarks even before the actual cessation of the publication of LIBOR by the IBA (i.e., the need for a "precessation trigger") and, if so, how this should be reflected in the contracts. ${ }^{14}$

\section{EU Benchmark legislation}

In the EU, the EU Benchmark Regulation (BMR) ${ }^{15}$ will come fully into force at the end of 2021 and will require that the administrators of relevant interest rate benchmarks incorporated in the EU be supervised by EU authorities.

The IBA was approved by the FCA in England as the administrator of the LIBOR on 27 April 2018.

The Belgian Financial Services and Markets Authority (FSMA) approved EMMI as the administrator of EURIBOR on 2 July 2019. ${ }^{16}$

As regards benchmarks administered by non-EU administrators, until such time as the EU adopts an equivalence decision regarding the relevant third country pursuant to Art. 30(2) and (3) of the EU BMR, the administrator must be recognised by the competent EU authorities in accordance with Art. 32 of the EU BMR. As an alternative to such recognition, a EU regulated administrator of benchmarks may endorse the third-country benchmark. For such endorsement, the requirements of Art. 33 of the EU BMR must be met.

Since 1 January 2018, the EU BMR requires that parties regulated in the EU and "using" a benchmark include "robust written plans" in their contracts to the effect of addressing the consequences of material changes to, or cessation of the publication of, such benchmarks. ${ }^{17}$ The parties falling into the scope of this obligation are any EU regulated entities, such as investment firms in the sense of MiFID, AIFMs, UCITS and their management companies. ${ }^{18}$ This obligation may for instance be complied with by incorporating the ISDA Benchmark

14 See <https://www.bankofengland.co.uk/-/media/boe/files/financial-stability-report/ 2019/december-2019.pdf>.

15 Regulation EU 2016/1011 of the European Parliament and the Council of 8 June 2016 on indices used as benchmarks in financial instruments and financial contracts or to measure the performance of investment funds and amending Directives 2008/48/EC and 2014/17/EU and Regulation (EU) No 596/2014.

16 See <https://www.esma.europa.eu/press-news/esma-news/authorisation-euriborunder-benchmark-regulation>.

17 See Art. 28(2) EU BMR.

18 See $<$ https://www.esma.europa.eu/sites/default/files/library/esma70-145-114 qas on bmr.pdf>. 
Supplement ${ }^{19}$ into a derivatives contract documented by reference to ISDA terms (i.e., by reference to the 2006 ISDA Definitions, the 2002 ISDA Equity Derivatives Definitions, the 1998 FX and Currency Option Definitions or the 2005 ISDA Commodity Definitions). In order to amend existing agreements by the inclusion of the ISDA Benchmark Supplement, the parties may adhere to the ISDA 2018 Benchmarks Supplement Protocol. ${ }^{20}$ To the extent that both parties to the relevant ISDA documentation have adhered to such protocol, the agreements are deemed to be amended accordingly without entering into a bilateral amendment agreement regarding such documentation.

\section{Other IBORs that are expected to be maintained}

\section{EURIBOR}

As regards the Euro, the EURIBOR, which is administered by the European Money Markets Institute (EMMI), is the most frequently used benchmark. ${ }^{21}$

EURIBOR is based, to the extent possible, on euro money market transactions that reflect the rate at which wholesale funds in EUR could be obtained by credit institutions in the EU and EFTA countries in the unsecured money market. To ensure robustness in the absence of such transactions, the EURIBOR methodology follows a waterfall, which works in a similar way as the revised methodology applied regarding LIBOR. On a first level, submissions by panel banks are based on transactions of the prior TARGET day. ${ }^{22}$ As a second level, submissions are based on transactions from recent TARGET days. As a third level, the submissions are based on transactions or other data from a range of markets closely related to the unsecured euro money market, using a combination of modeling techniques or the judgment of the panel bank. ${ }^{23}$

Because the EURIBOR and EMMI are approved by the Belgian FSMA under the EU BMR, EURIBOR may be considered as BMR-compliant and may be maintained also beyond the end of 2021.

\footnotetext{
19 See <https://www.isda.org/a/mOREE/A34965328-v36.0-ISDA-BenchmarksSupplement.pdf $>$.

20 See $<$ https://www.isda.org/protocol/isda-2018-benchmarks-supplement-protocol/>.

21 See $<$ https://www.emmi-benchmarks.eu/>>

22 TARGET day means a day on which the Trans-European Automated Real-Time Gross Settlement Express Transfer System is operating.

23 See the description of the methodology in <https://www.emmi-benchmarks.eu/assets/ files/D0016A-2019 Benchmark Determination Methodology for EURIBOR.pdf>.
} 
However, the Euro Overnight Index Average (EONIA), which is also administered by EMMI, will case to be published as of the end of 2021 and be replaced by €STR by such date. ${ }^{24}$

\section{TIBOR}

The Tokyo Interbank Offered Rate (TIBOR) has been calculated and published by the Japanese Bankers Association (JBA) for "Japanese Yen TIBOR" rates since November 1995 and "Euroyen TIBOR" rates since March 1998. The "Japanese Yen TIBOR" reflects prevailing rates on the unsecured call market and the "Euroyen TIBOR" the offshore market for Japanese Yen.

The TIBOR is expected to be maintained beyond the end of 2021 and to coexist with TONA as the new RFR. ${ }^{25}$

\section{Risk-free Rates as alternatives to LIBOR rates}

\section{Risk-free rates}

To meet the requirements that have been established by the FSB, an alternative benchmark that may be used to replace LIBOR must have the following characteristics that distinguish it from LIBOR: (1) It must not be based on a discretionary determination by an administrator or contributors to the benchmark, but it must be determined by following a transaction-based methodology. (2) The rate must be an overnight rate, calculated for overnight borrowings. (3) The rate must not be based on the interbank lending market, but it must be based on secured or unsecured transactions entered into in a wider market. ${ }^{26}$

The discontinuation of LIBOR rates will lead to a fragmentation in two dimensions: On the one hand, each currency will have its own solution for an alternative benchmark. On the other hand, the derivatives, loans and floating rate notes markets will probably not be fully aligned as regards the solutions for the adjustments to be applied with respect to the use of alternative riskfree rates (RFRs), e.g. with respect to the use of overnight rates instead of

\footnotetext{
24 See $<$ https://www.emmi-benchmarks.eu/euribor-eonia-org/about-eonia.html > and IV.1.

25 See IV.1.

26 See SCHRIMPF/SuSHKO, Beyond LIBOR, 29, available on <https://www.bis.org/publ/qtrpdf/ r_qt1903e.pdf>.
} 
forward-looking term rates and the spread adjustments addressing the move from rates taking into account the credit risk of the interbank market to riskfree rates or nearly risk-free rates.

Under the guidance of the OSSG, the national working groups in the relevant markets have identified RFRs that will be used as alternative to the LIBOR rates. Such RFRs are the following rates:

\begin{tabular}{|l|l|l|}
\hline Currency & IBOR & RFE \\
\hline CHF & $\begin{array}{l}\text { CHF } \\
\text { LIBOR }\end{array}$ & $\begin{array}{l}\text { In Switzerland, the National Working Group (NWG) identified the Swiss } \\
\text { Average Rate Overnight (SARON) }\end{array}$ \\
\hline USD & $\begin{array}{l}\text { USD an alternative RFR. } \\
\text { LIBOR }\end{array}$ & $\begin{array}{l}\text { In the US, the Alternative Reference Rate Committee (ARRC), which is a } \\
\text { group of private-market participants convened by the New York Fed, } \\
\text { identified the Secured Overnight Financing Rate (SOFR) } \\
\text { native RFR. }\end{array}$ \\
\hline abP the alter- \\
\hline AUD & $\begin{array}{l}\text { GBP } \\
\text { LIBOR }\end{array}$ & $\begin{array}{l}\text { In England, the Working Group on Sterling Risk Free Rates determined } \\
\text { the Sterling Overnight Index Average (SONIA) }\end{array}$ \\
\hline JPY alternative RFR.
\end{tabular}

27 See $<$ https://www.snb.ch/en/ifor/finmkt/id/finmkt_repos_saron\#t2>.

28 See $<$ https://apps.newyorkfed.org/markets/autorates/SOFR $>$.

29 See $<$ https://www.bankofengland.co.uk/markets/sonia-benchmark>.

30 See $<$ https://www.rba.gov.au/statistics/cash-rate/>.

31 See <https://www.boj.or.jp/en/statistics/market/short/mutan/index.htm/>.

32 See <https://www.refinitiv.com/en/financial-data/financial-benchmarks/interest-ratebenchmarks/canadian-interest-rates $>$. 


\begin{tabular}{|l|l|l|}
\hline Currency & IBOR & RFE \\
\hline EUR & $\begin{array}{l}\text { EUR } \\
\text { LIBOR; } \\
\text { EURIBOR }\end{array}$ & $\begin{array}{l}\text { In Europe, } \text { LSTR }^{33} \text { has been designated as alternative RFR to EUR } \\
\text { LURIBR. }\end{array}$ \\
\hline
\end{tabular}

LIBOR is fixed at the beginning of the interest period and may then be applied to determine interest payments that become due and payable at the end of the interest period. The RFRs are - as opposed to LIBOR - overnight rates. As a result, if they shall be used in respect of a calculation period exceeding one day, the daily rates must be adjusted for the relevant term.

The standard term adjustment for the RFRs will be a compounding over the relevant calculation period. ${ }^{34}$ However, the compounded rates will only be known as of the end of the relevant calculation period, unless the relevant values will be taken from the previous calculation period. In this respect, the use of the RFRs is very different from LIBOR rates, which are known as of the start of the relevant calculation period.

SARON is published on the day of fixing, i.e., at 6 p.m. on the same day as the determination is made. However, as regards the other RFRs, the publication occurs on the following day after the fixing.

For some of these RFRs, the market anticipates that existing benchmarks will continue to be published in a modified form. This is planned for Australia, Japan, Canada and the EU. In the EU, the EURIBOR will continue to exist, while the EUR-LIBOR and EONIA will cease. ${ }^{35}$

In respect of some RFRs, forward-looking term rates, which will be determined on the basis of derivatives transactions regarding such RFRs as underlyings, may be published in addition to the RFRs. This will not be the case for Switzerland on the basis that the NWG does not expect there will be a sufficiently liquid futures market for SARON allowing the reliance on a forward-looking term rate that is not subject to the discretion of very few market participants in the SARON futures market. The situation is different

33 See $<$ https://www.ecb.europa.eu/stats/financial_markets_and_interest_rates/euro short-term_rate/html/index.en.html>.

34 See IV.2.

35 See III.1. 
in England, the USA and in Europe, and probably also in Japan. Here, the market expects that forward-looking term rates will be published on the basis of derivatives referencing the relevant RFRs. ${ }^{36}$

\section{Compounding of alternative risk-free rates}

To the extent it is acceptable for the parties to determine the alternative RFRs at the end of the respective interest periods, the relevant RFR may be compounded in arrears at the end of the relevant interest period. With such method, the compounded setting in arrears rate is the relevant RFR observed over a period of time that is set by reference to the relevant interest period and compounded daily during that period.

For instance, in respect of SARON as the RFR for CHF LIBOR, the compounding can be expressed with the following formula:

$$
\left[\prod_{i=l}^{d_{o}}\left(1+\frac{S A R O N_{i} \times n_{i}}{360}\right)-1\right] \times \frac{360}{d}
$$

" $\mathrm{d}_{\mathrm{o}}$ ", for any calculation period, is the number of banking days in the relevant calculation period.

" $\mathrm{i}$ " is a series of whole numbers from one to $d_{0}$, each representing the relevant banking days in chronological order from, and including, the first banking day in the relevant calculation period.

"SARONi", for any day "i" in the relevant calculation period, is the relevant SARON overnight rate.

" $\mathrm{n}_{\mathrm{i}}$ " is the number of calendar days in the relevant calculation period on which the rate is $\mathrm{SARON}_{\mathrm{i}}$.

"d" is the number of calendar days in the relevant calculation period.

In a base scenario, the calculation period runs exactly for the same time as the interest period and the compounded RFR would only be available on the last day of such calculation period. This base scenario may not be suitable for

36 See <https://www.snb.ch/n/mmr/reference/minutes 20191113/source/minutes 20191113.n.pdf>. 
cases, where the compounded RFR should be already determined as of a day prior to the last day of the interest period (e.g. for operational reasons, in order to make the relevant payments).

If the compounded RFR must be available prior to the last day of the interest period, the calculation could be made by reference to a calculation period that runs differently than the interest period.

For instance, it would be possible to start the calculation period at the same time as the interest period, but to end the calculation period a few days prior to the end of the interest period (this method is referred to as "lockout"). ${ }^{37}$ By proceeding accordingly, the compounded RFR would be known already prior to the end of the interest period.

Alternatively, it would be possible to start the calculation period a few days prior to the start of the interest period and end it also a few days prior to the end of the interest period (this method is referred to as "lookback" or, in the terminology used by ISDA, "backward-shift"). ${ }^{38}$ Also with this method, the compounded RFR would be known already prior to the end of the interest period.

For floating rate notes in CHF, the NWG published a termsheet with recommendations for the preferred language when using SARON, including the relevant terms for compounding and fallbacks for the cessation of SARON. ${ }^{39}$ Such proposal recommends a calculation with the "lookback" or "backward-shift" method, starting the calculation period for the relevant interest period five days prior to the start of the interest period and ending it five days prior to the end of the relevant interest period.

To the extent it is not acceptable for the parties to determine the alternative RFRs at the end of the respective interest periods, the relevant RFR may be determined in advance by reference to the values of a calculation period

37 NWG minutes meeting 23 November 2019, slide 14, option 2, available on <https://www.snb.ch/n/mmr/reference/minutes_20191113/source/minutes 20191113.n.pdf>.

NWG minutes meeting 23 November 2019, slide 14, option 3, available on $<$ https://www.snb.ch/n/mmr/reference/minutes 20191113/source/minutes_20191113.n.pdf>. The weighting and the rate are shifted backwards by a certain number of banking days.

39 See $<$ https://www.snb.ch/n/mmr/reference/SARON FRN 20190702/source/SARON FRN_20190702.n.pdf>. 
ending prior to the start of the interest period. For instance, it would be possible to use the daily rates of the previous interest period as the relevant calculation period (this method is referred to as "last reset"). ${ }^{40}$

\section{Fallbacks}

\section{Need for the agreement of fallbacks}

On the basis of the estimates of the ARRC, the outstanding gross notional amount of all financial products referencing USD LIBOR was approximately USD 199 trillion at the end of 2016, including USD 145 trillion of OTC derivatives, USD 45 trillion of exchange-traded derivatives and USD 8.3 trillion of cash products. Approximately $77 \%$ of such OTC derivatives, $99 \%$ of exchange-traded derivatives and $71 \%$ of such cash products are expected to mature prior to the end of 2021. This leaves approximately $23 \%$ of OTC derivatives and $29 \%$ of cash products that would have a maturity beyond the expected end of LIBOR. ${ }^{41}$

The market share of the transactions referencing LIBOR rates with a maturity after the end of 2021 will depend on the uptake of the trading activity in the RFRs prior to the end of LIBOR.

Looking at the statistics of the derivatives markets for 2019, the traded notionals referencing RFRs increased to USD 8.7 trillion compared to USD 8.1 trillion in 2018. However, by reference to the overall trading activity in interest rate derivatives, this amounted to approximately $3.4 \%$ of the traded notional amounts. ${ }^{42}$ The currency with the largest count of RFR trading was GBP with a share of more than $40 \%$ of trading in SONIA compared to GBP LIBOR in 2019, counting notional amounts. However, looking at the trading

40 NWG minutes meeting 23 November 2019, slide 14, option 4, available on <https://www.sixgroup.com/exchanges/indices/data_centre/swiss_reference_rates/compound_rates_en.html>.

41 See Second Report, The Alternative Reference Rates Committee, March 2018, available on $<$ https://www.newyorkfed.org/medialibrary/Microsites/arrc/files/2018/ARRC-Secondreport>; also ISDA Research Note, February 2020, available on $<$ https://www.isda.org/a/ WhXTE/Adoption-of-Risk-Free-Rates-Major-Developments-in-2020.pdf>.

42 See

$<$ https://www.isda.org/a/W5LTE/Interest-Rate-Benchmarks-Review-FullYear-2019-and-Q4-2019.pdf>. 
volume in USD, the share of trading in SOFR was only approximately $0.3 \%$. As regards CHF, the share of trading in SARON was approximately $4 \%$ of the traded notional amounts. The relevant data is as follows: ${ }^{43}$

\begin{tabular}{|l|r|r|}
\hline & \multicolumn{2}{|l|}{$\begin{array}{l}\text { traded notionals } \\
\text { (in billions USD) in 2019 }\end{array}$} \\
\hline USD LIBOR & $119,439.2$ & 683,146 \\
\hline SOFR & 392.7 & 1,279 \\
\hline GBP LIBOR & $10,360.2$ & 91,020 \\
\hline SONIA & $8,014.9$ & 12,618 \\
\hline CHF LIBOR & 618.2 & 8,745 \\
\hline SARON & 25.6 & 66 \\
\hline JPY LIBOR & $3,985.5$ & 40,078 \\
\hline TIBOR / Euroyen & 10.5 & 105 \\
TIBOR & 250.8 & 505 \\
\hline TONA & 1.1 & 9 \\
\hline EUR LIBOR & $22,883.9$ & 10 \\
\hline EURIBOR & 4.6 & 453,691 \\
\hline$€$ STTR & 89,312 & 200,402 \\
\hline Other IBORs & & 19 \\
\hline
\end{tabular}

What approach should be taken with respect to legacy transactions that have a maturity beyond the end of LIBOR?

There will be two possible strategies. Either to replace such transactions before the date of the LIBOR cessation becoming effective with new transactions entered into by reference to the RFRs or, if this is not possible, to amend existing transactions by incorporating fallback clauses that specify how the transition to the risk-free rates shall occur.

\section{Content of fallbacks}

A fallback clause must address three matters: firstly, it must include the trigger for the transition to the fallback rate. Secondly, the clause must specify the alternative risk-free rates that will apply in the event of a cessation of the relevant rate. Thirdly, the fallback clause must specify the adjustments that

43 See

$<$ https://www.isda.org/a/W5LTE/Interest-Rate-Benchmarks-Review-Full-

Year-2019-and-Q4-2019.pdf>. 
shall apply with respect to the move to the relevant fallbacks, including a term adjustment to address the differences in the term structure of the two rates (i.e., in respect of fallbacks to LIBOR, the move from a forward-looking term rate to an overnight rate) and a spread adjustment taking into account any differences with respect to credit risk (i.e., in respect of fallbacks to LIBOR, the move from a rate addressing interbank credit exposure to a rate based on secured transactions or transactions traded in a wider market).

\section{Fallback clauses of Derivatives Transactions}

\section{a) Derivatives Documentation}

OTC derivatives transactions are, as a matter of standard practice, documented under master agreements entered into for the trading relationship. The master agreements most frequently used in the market are those published by the International Swaps and Derivatives Association, Inc. (ISDA), which are available in a version of 2002 and a version of 1992 (the 2002 ISDA Master Agreement and the 1992 ISDA Master Agreement). The ISDA Master Agreements may be expressed, upon election of the parties, to be governed by English law or by the laws of the State of New York. An English law governed ISDA Master Agreement includes a choice of jurisdiction specifying that English courts are the competent courts to hear a dispute and a New York law governed ISDA Master Agreement provides for the choice of jurisdiction of New York courts. Most recently, ISDA published also versions of the ISDA Master Agreements governed by Irish law and by French law in order to allow the parties to enter into Master Agreements in a post-Brexit context, which are expressed to be governed by a law of an EU member state and provide for the choice of jurisdiction of courts of an EU member state.

The parties to an ISDA Master Agreement agree the relevant elections that apply to their trading relationship in a Schedule to the ISDA Master Agreement. Such elections include, besides the choice of the governing law, for instance also the inclusion of additional events of default or termination events, the relevant elections for the calculation of termination payments in the event of an early termination (e.g. as regards the time when the early termination is effective and the election of the termination currency), the inclusion of notice details and process agents, the inclusion of additional representations and the relevant provisions that may be needed for the purposes of ensuring regulatory compliance of the trading relationship.

Transactions entered into under ISDA Master Agreements are documented under confirmations referring to the relevant ISDA Master Agreement. Such 
transaction confirmations incorporate, depending on the asset class of the underlying, definitions that have been published by ISDA and provide for standard mechanics (e.g. regarding the relevant cash flows and calculations), which do not need to be restated in the confirmations as a result of their inclusion by reference into the confirmation. For interest rate products or any cash flows relating to the interest rates, the 2006 ISDA Definitions are the relevant definitions included in the documentation.

In addition to ISDA Master Agreements, the derivatives market uses also other types of master agreements for local markets. In Switzerland, we have the Swiss Master Agreement published by the Swiss Bankers Association, which is governed by Swiss law and includes a choice of jurisdiction for Swiss courts. ${ }^{44}$ The Swiss Master Agreement was first published in 2003. It was published as an updated version in 2013, including also relevant definitions applying to the transactions. The 2013 version of the Swiss Master Agreement is available in two versions: a version that would allow the inclusion of certain ISDA definitions by way of an incorporation by reference (i.e., regarding interest rate products, the 2006 ISDA Definitions) and a version (non-ISDA version) designed as a stand-alone document without any references to ISDA definitions.

\section{b) Trigger Events}

ISDA intends to implement the relevant fallback clauses in a supplement to the 2006 ISDA Definitions, which are the relevant ISDA definitions applicable to interest rate benchmarks, and in a "Protocol" (ISDA Fallbacks Protocol) for inclusion of the fallbacks in legacy transactions, i.e., transactions already in place at the time of the publication of the supplement to the 2006 ISDA Definitions and with a term beyond the cessation of LIBOR. ${ }^{45}$

The fallback clauses may include triggers by reference to the following: ${ }^{46}$

(1) a public statement or publication by or behalf of the relevant administrator of the relevant IBOR announcing that it has ceased or will cease to provide the relevant IBOR permanently or indefinitely, provided that there is no successor that will continue to provide the relevant IBOR;

(2) a public statement or publication by the regulatory supervisor for the administrator of the IBOR, the central bank for the currency of the relevant IBOR, an insolvency official with jurisdiction over the administrator

\footnotetext{
44 See $<$ https://www.swissbanking.org/en/services/library/master-agreements-forms $>$.

45 See below under V.3.g).

46 Reference is made to ISDA, IBOR Fallbacks July 2018 Consultation.
} 
of the IBOR, a resolution authority with jurisdiction over the administrator of the IBOR or a court or an entity with similar insolvency or resolution authority over the administrator of the IBOR, which states that the administrator of the IBOR has ceased or will cease to provide the IBOR permanently or indefinitely, provided that there is no successor that will continue to provide the relevant IBOR; and

(3) regulator determing that a LIBOR rate has ceased to be representative and a fallback should apply as a result.

The effective date of the events under (1) and (2) may be at a later point in time than the occurrence of the relevant event. For instance, if the administrator of a relevant IBOR announces in advance that it will cease to publish the relevant IBOR at a certain date in the future, the event would have occurred as of such announcement, but the fallbacks will only apply on the future date when the publication of the IBOR will cease. ${ }^{47}$

To the extent that panel banks cease to provide LIBOR submissions, the question arises whether LIBOR will be deemed to have lost its representativeness and, as a result, whether a regulator will determine that a pre-cessation trigger event (a Pre-Cessation Trigger Event) has occurred.

\section{c) Alternative risk-free rates}

As regards the identification of alternative risk-free rates, the 2006 ISDA Definitions and the ISDA Fallbacks Protocol will include provisions mapping the relevant IBORs to alternative risk-free rates. Moreover, these provisions will also include secondary fallbacks for the event of a cessation of a primary fallback.

\section{d) Term adjustment}

ISDA consulted with the derivatives market participants as regards the approach to be taken to address the differences in the tenors between IBORs and the overnight RFRs. The result of these consultations showed a preference of the derivatives market for a "compounded setting in arrears" rate to be

47 This was the case e.g. for EONIA, where it has already been announced by EMMI as the benchmark administrator that it will cease to be published at the end of 2021 see <https://www.emmi-benchmarks.eu/euribor-eonia-org/about-eonia.html>. 
determined in respect of each IBOR tenor ${ }^{48}$ and a "lookback/backward-shift" of the calculation period by two banking days for the determination of the term adjusted overnight RFR. ${ }^{49}$

As a result, assuming that the supplement to the 2006 ISDA Definitions and the ISDA Fallbacks Protocol will implement the outcome of these consultations, the derivatives market will use overnight RFRs, which will be compounded for each interest period as of the end of the relevant interest period with the "ookback/backward-shift" method. ${ }^{50}$

As of the first interest period after the relevant trigger event becoming effective, the calculation would be made on the basis of a calculation period that starts two days before the beginning of the relevant interest period and ends two days before the end of the interest period. This would allow the relevant values to be known prior to the end of the interest period, i.e., prior to the date the payments become due.

\section{e) Spread adjustment}

To address the differences in the credit and liquidity risk and further factors, such as fluctuations in supply and demand between the relevant IBORs and the RFRs, a spread is added to the relevant value (spread adjustment). ${ }^{51}$

In its consultations, ISDA also sought the views of the derivatives market participants as regards the methodology to be applied for such spread adjustment. The outcome was a preference for the calculation of a historical median over a five-year lookback period as opposed to a calculation on the basis of a mean, which would be calculated over a longer look-back period, subject to the trimming of outliers. ${ }^{52}$

On the basis of the consultations, it is the preference of the market to set the spread adjustment at the time the fallbacks will be applied without providing

48 Reference is made to ISDA, IBOR Fallbacks July 2018 Consultation, and ISDA/The Brattle Group, Summary of Responses to Consultation on Term Fixings and Spread Adjustment Methodologies.

49 Reference is made to ISDA, IBOR Fallbacks September 2019 Final Parameters Consultation, and ISDA/The Brattle Group, Summary of Consultation on Final Parameters for the Spread and Term Adjustments.

$50 \quad$ See IV.2.

51 Reference is made to ISDA, IBOR Fallbacks July 2018 Consultation.

52 Reference is made to ISDA, IBOR Fallbacks September 2019 Final Parameters Consultation, and ISDA/The Brattle Group, Summary of Consultation on Final Parameters for the Spread and Term Adjustments. 
for a gradual phase-in over a transition period. ${ }^{53}$ On the assumption that such spread adjustment will be implemented according to the results of these consultations, a spread adjustment will be set for each LIBOR tenor and such adjustment will be determined as of the date the relevant fallback will be effective.

\section{f) Publication of adjusted risk-free rates}

It is the intention that Bloomberg will publish on behalf of ISDA the term- and spread-adjusted RFRs in the relevant tenors. For each such tenor, Bloomberg will publish three values: the term-adjusted RFR, the relevant spread and an "all-in" rate as the aggregate of the term-adjusted RFR and the spread.

It is planned to start the publication of indicative figures before a the occurrence of a trigger event. However, the final figures will only be available when a trigger event for the application of the fallbacks has become effective.

\section{g) Implementation in ISDA Documentation}

\section{aa) Supplement to 2006 ISDA Definitions}

The fallback clauses will be included in a supplement to the 2006 ISDA Definitions. As a result, as of the publication by ISDA of such supplement, any derivatives transactions documented in a confirmation referring to the 2006 ISDA Definitions will include such fallbacks specified in the supplement to the 2006 ISDA Definitions.

\section{bb) ISDA Protocol}

As regards legacy transactions entered into prior to the date of the publication of the supplement to the 2006 ISDA Definitions, which have a term that runs beyond the cessation of LIBOR, the question arises how such transactions shall be amended to include the relevant fallback clauses.

ISDA intends to publish a protocol incorporating the fallback clauses included in the supplement to the 2006 ISDA Definitions (ISDA Fallbacks Protocol). ${ }^{54}$ To the extent that both parties to a transaction adhere to such protocol, they

53 ISDA/The Brattle Group, Summary of Consultation on Final Parameters for the Spread and Term Adjustments.

54 See

$<$ https://www.isda.org/a/WWXTE/ISDA BMR-and-Interest-Rate-ReformWorkstreams.pdf>. 
will apply such fallback clauses to the transactions covered by the protocol without having to amend all legacy transactions by way of a bilateral agreement.

As regards the scope of such ISDA Fallbacks Protocol, ISDA intends to cover not only transactions entered into under ISDA Master Agreements or by reference to the 2006 ISDA Definitions, but to apply a broader scope, covering also some transactions entered into under non-ISDA documentations specified in an Annex to the ISDA Fallback Protocol, provided that they include any cashflows that are determined by reference to a relevant IBOR. Such list shall include the Swiss Master Agreements OTC derivatives transactions published by the Swiss Bankers Association (including the versions of 2003 and 2013).

Also, it is ISDA's intention that the ISDA Fallbacks Protocol will amend collateral documentations by incorporating the relevant fallback clauses also for the purposes of the calculation of interest payments.

\section{cc) Bilateral Agreement}

As regards transactions entered into between parties who will not adhere to the ISDA Fallbacks Protocol to be published by ISDA, the parties may enter into a bilateral agreement for the purposes of including the relevant fallback clauses into such transactions.

Also, even if two parties have adhered to the ISDA Fallbacks Protocol published by ISDA, they may nevertheless have to enter into a bilateral amendment agreement if they are also trading derivatives transactions under a documentation, which is not covered by the ISDA Fallbacks Protocol.

In such a bilateral agreement, the parties may include the relevant fallbacks by incorporating by reference the terms of the ISDA Fallbacks Protocol.

\section{h) Implementation for local Swiss Documentation}

aa) Protocol vs. bilateral agreement

Even if Swiss Master Agreements will fall into the scope of the ISDA Fallbacks Protocol, to the extent that parties will not both adhere to such protocol, they will have to amend the relevant contracts by way of a bilateral amendment agreement in order to incorporate fallback clauses. 


\section{bb) Benchmark Amendment Agreement}

The Swiss Bankers Association will publish a Benchmark Amendment Agreement (Benchmark Amendment Agreement) that may be entered into as a bilateral agreement by parties to (i) a Swiss Master Agreement for OTC Derivative Instruments published by the Swiss Bankers Association (including (a) the 2003 version, (b) the 2013 version for use in connection with certain ISDA Definitions and (c) the 2013 non-ISDA version not for use in connection with any ISDA Definitions), ${ }^{55}$ (ii) a Swiss Master Agreement for Repo Transactions published by the Swiss Bankers Association (bilateral 1999 version, multilateral 1999 version) ${ }^{56}$ and (iii) a Swiss Master Agreement for Securities Lending and Borrowing prepared by the Swiss Bankers Association (2011 version) for the purposes of including into such Swiss law governed master agreements the same fallbacks as those specified in the ISDA Fallbacks Protocol.

In addition to including such fallbacks, it is intended that the Benchmark Amendment Agreement will include clauses specifying how RFRs are compounded, where the parties do not agree differently in the relevant transactions.

Moreover, the Benchmark Amendment Agreement shall include the relevant fallbacks for the transition from EONIA to €STR as the relevant fallback rate when EONIA cessation is scheduled to occur at the end of 2021.

\section{Interrelation of derivatives with loans}

\section{Proposed solutions for loans}

The LMA recently published exposure drafts for loan documentations using SONIA and SOFR ${ }^{57}$ However, these loan documents are not yet widely used.

For the loan market, it is yet to be seen to what extent forward-looking term rates will be used once they are available. ${ }^{58}$

As regards legacy transactions referencing LIBOR rates with a term exceeding the end of LIBOR, the loan market will - as opposed to the derivatives market - not have the benefit of a protocol solution to include fallback clauses into

\footnotetext{
55 See $<$ https://www.swissbanking.org/en/services/library/master-agreements-forms $>$.

56 See $<$ https://www.swissbanking.org/en/services/library/master-agreements-forms $>$.

57 See $<$ https://www.lma.eu.com/news-publications/press-releases?id=170>.

58 See IV.1.
} 
all loan agreements affected by the LIBOR cessation. At present, it is common practice under LMA loan documentations to include screen rate replacement clauses into the loan agreements. However, such clauses will nevertheless require bilateral agreements for the inclusion of actual fallbacks.

\section{Basis risk}

The divergence of the applicable fallbacks between the loan market and the derivatives market may give rise to basis risk. This would for instance be the case, where a loan agreement included a fallback to a forward-looking term rate and the derivative hedging a floating rate includes a fallback to an overnight rate that is adjusted as specified in the ISDA Fallbacks Protocol to be published by ISDA, i.e., it is compounded in arrears with the lookback/ backward-shift method and adjusted with the spread adjustment to be published by Bloomberg on behalf of ISDA.

Such basis risk could, for example, be eliminated by entering into a swap with a swap counterparty under which the forward looking term rate is exchanged for the adjusted overnight rate, as published by ISDA.

\section{Litigation risk}

\section{Failing to agree on Fallbacks for legacy transactions}

To the extent that parties do not agree to the inclusion of fallbacks - either by way of adherence to the ISDA Fallbacks Protocol or by way of entering into a bilateral amendment agreement - there would be a material risk that the cash flows calculated by reference to a LIBOR rate could no longer be determined at the time of the LIBOR cessation. Such agreements with a term exceeding the end of LIBOR are also referred to as "tough legacy" transactions.

A party that could enter into a new transaction on better terms compared to the situation, where it would agree to honour the continuation of the LIBORbased transaction by consenting to an overnight RFR, as adjusted with a term and spread adjustment, may hold off its consent to the amendment and argue that the obligations have been frustrated. ${ }^{59}$

This argument could be disputed by the other party with the argument that the LIBOR cessation is a change in the circumstances that should be classified

See VIRJI/MERALI/MARSHALL, BJIBFL 2019, 715 et seq. 
as requiring an adjustment of the terms of the contract by a court under the doctrine of the "clausula rebus sic stantibus", which applies under general principles of Swiss contract law.

\section{Challenge to compound interest}

As regards the compounding of overnight rates, the question may arise whether the counterparty may challenge a compounding methodology and instead request the calculation on the basis of an arithmetic mean and, if a court were to grant a counterparty such a right, whether the counterparty may request a switch to a calculation using an arithmetic mean at any point in time. This risk may become particularly relevant for contracts entered into with consumers. ${ }^{60}$

To eliminate such risk, the parties could agree a compounding method using the compounded values of a previous interest period. ${ }^{61}$ By applying such method, the counterparty would be on notice of the compounded rate at the beginning of each interest period.

Where the parties use a "compounding in arrears" method, the risk of a counterparty requesting a switch to a calculation on the basis of an arithmetic mean could be mitigated by informing the counterparty of the formula used for the compounding and providing the counterparty at any time the possibility to calculate the compounded values for the running interest period by using a calculator applying the current values up to the end of the interest period.

\section{Outlook}

The clock for the LIBOR cessation continues to tick. Given the timeline that has been set by the regulators, we can expect that panel banks will withdraw from making submissions to LIBOR by the end of 2021. Depending on the way how panel banks withdraw from the process of making submissions to LIBOR, the triggers for the application of fallbacks may become relevant soon after the end of 2021, to the extent that there will be an industry consensus to include pre-cessation triggers into the relevant fallback clauses.

In respect of many derivatives transactions the ISDA Fallbacks Protocol to be published by ISDA will provide an industry solution in order to include

\footnotetext{
60 See for instance BRÄNDLI, AJP 20191260 et seq.

61 See IV.2.
} 
fallbacks into legacy transactions. However, there will be counterparties that do not adhere to such protocol and there will be transactions that are not in scope of the protocol.

In any event, it is key to identify the relevant portfolios of transactions that will have to be redocumented in order to make sure that all transactions referring to LIBOR rates with a term exceeding the end of LIBOR will include the relevant fallback clauses allowing a continued calculation of the relevant cashflows beyond the cessation of LIBOR.

If such fallback clauses are not included in the contracts, from today's perspective, there is a material risk that such "tough legacy" portfolios will result in litigation between the parties, given that arguments may be brought forward both for a frustration of the relevant obligations when LIBOR ceases to be published and for an adjustment of the contracts by including the relevant fallbacks as the deemed intention of the parties. In the absence of an intervention by the legislator, e.g. by amending the contracts by operation of law or by ordering a publication of a "synthetic LIBOR", it remains the responsibility of the counterparties to the contracts to agree to the inclusion of fallbacks in a timely manner prior to the LIBOR cessation in order to address such litigation risk.

\section{Literature}

BRÄNDLI BEAT, Wechsel von CHF LIBOR zu SARON, Rechtliche Implikationen und Herausforderungen der Einführung des neuen Referenzzinssatzes, AJP 2019, 1260 et seq. SCHRIMPF ANDERAS/SUSHKO VLADYSLAV, Beyond LIBOR: a primer on the new reference rates, available on <https://www.bis.org/publ/qtrpdf/r qt1903e.pdf> (SCHRIMPF/SUSHKO, Beyond LIBOR).

VirJi Hanif/Merali ARIF/Marshall PaUl, Facing the end of LIBOR: the financial and legal implications, BJIBFL 2019, 715 et seq.

\section{Sources}

FSB, Reforming Major Interest Rate Benchmarks, 22 July 2014 (FSB, 2014 Report).

FSB, Reforming Major Interest Rate Benchmarks: 2019 Progress Report, 18 December 2019 (FSB, 2019 Progress Report).

ISDA, Interbank Offered Rate (IBOR) Fallbacks for 2006 ISDA Definitions, Consultation on Certain Aspects of Fallbacks for Derivatives Referencing GBP LIBOR, CHF LIBOR, JPY LIBOR, TIBOR, Euroyen TIBOR and BBSW, 12 July 2018 (ISDA, IBOR Fallbacks July 2018 Consultation). 
ISDA/The Brattle Group, Anonymized Narrative Summary of Responses to the ISDA Consultation on Term Fixings and Spread Adjustment Methodologies, 20 December 2018 (ISDA/The Brattle Group, Summary of Responses to Consultation on Term Fixings and Spread Adjustment Methodologies).

ISDA, Interbank Offered Rate (IBOR) Fallbacks for 2006 ISDA Definitions, Supplemental Consultation on Spread and Term Adjustments for Fallbacks in Derivatives Referencing USD LIBOR, CDOR and HIBOR and Certain Aspects of Fallbacks for Derivatives Referencing SOR, 16 May 2019 (ISDA, Supplemental IBOR Fallbacks May 2019 Consultation).

ISDA, Consultation on Pre-Cessation Issues for LIBOR and Certain Other Interbank Offered Rates (IBORs), 16 May 2019 (ISDA, May 2019 Pre-Cessation Consultation).

ISDA, Frequently Asked Questions: EURIBOR reform, 10 September 2019 (ISDA, EURIBOR FAQ).

ISDA, Interbank Offered Rate (IBOR) Fallbacks for 2006 ISDA Definitions, Consultation on Final Parameters for the Spread and Term Adjustments in Derivatives Fallbacks for Key IBORs, 18 September 2019 (ISDA, IBOR Fallbacks September 2019 Final Parameters Consultation).

ISDA/The Brattle Group, Anonymized Narrative Summary of Responses to the ISDA PreCessation Consultation, 21 October 2019 (ISDA/The Brattle Group, Summary of Responses to May 2019 Pre-Cessation Consultation).

ISDA/The Brattle Group, Summary of Responses to the ISDA Consultation on Final Parameters for the Spread and Term Adjustments, 15 November 2019 (ISDA/The Brattle Group, Summary of Consultation on Final Parameters for the Spread and Term Adjustments).

ISDA, Interbank Offered Rate (IBOR) Fallbacks for 2006 ISDA Definitions, Supplemental Consultation on Spread and Term Adjustments, including Final Parameters thereof, for Fallbacks in Derivatives Referencing EUR LIBOR and EURIBOR, as well as other less widely used IBORs, 18 December 2019 (ISDA, IBOR Fallbacks December 2019 Supplemental Consultation).

ISDA, Interest Rate Benchmarks Review: Full Year 2019 and the Fourth Quarter of 2019, January 2020 (ISDA, Interest Rate Benchmarks Review January 2020).

ISDA, Research Note, Adoption of Risk-Free Rates: Major Developments in 2020, February 2020 (ISDA, Research Note, February 2020).

ISDA, 2020 Consultation on How to Implement Pre-Cessation Fallbacks in Derivatives, 25 February 2020 (ISDA, 2020 Consultation on Pre-Cessation Fallbacks).

National Working Group on CHF Reference Rates, minutes of 23rd Meeting, 12 November 2019 (NWG minutes meeting 23 November 2019). 



\title{
CSR und Kapitalmarkt
}

\author{
Annette Weber/Thomas U. Reutter
}

\section{Inhalt}

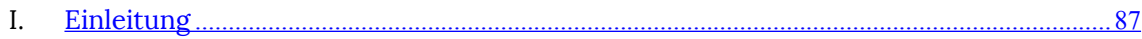

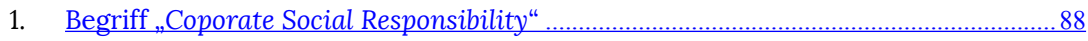

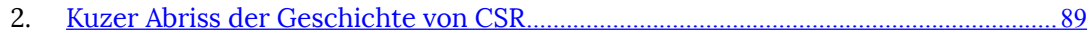

3. Heutige Rechtslage ………………………………………………………………….....90

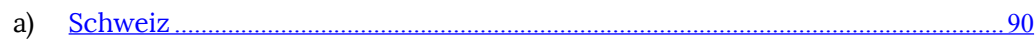

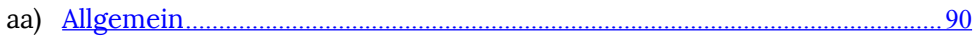

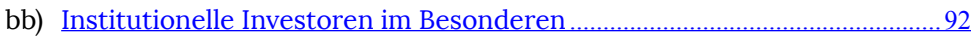

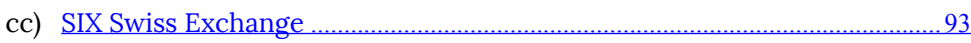

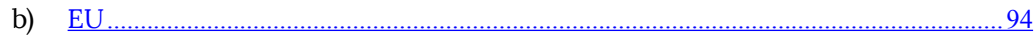

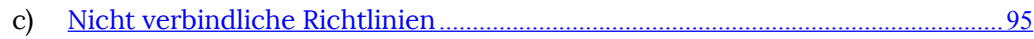

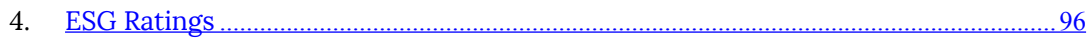

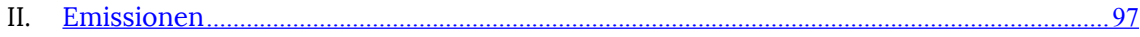

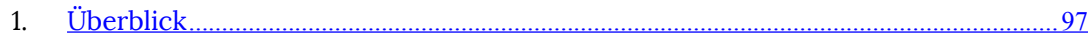

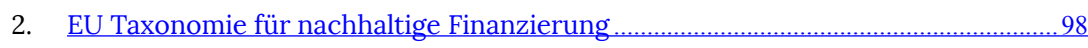

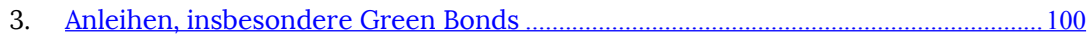

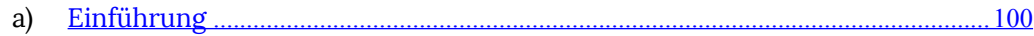

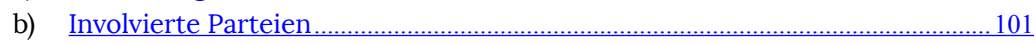

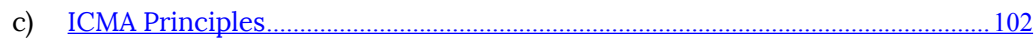

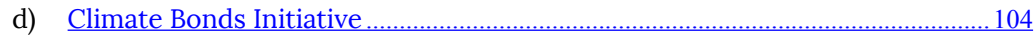

e) EU Green Bond Standard (de lege ferenda) ............................................. 106

f) Umsetzung in der Schweiz ...................................................................... 106

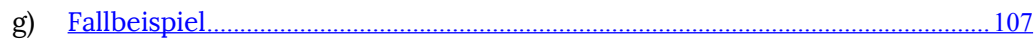

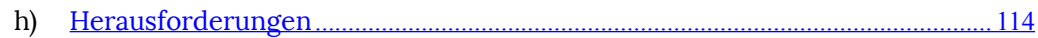

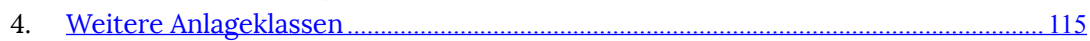

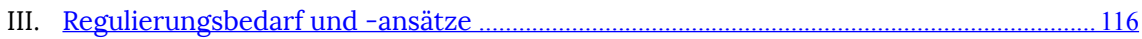

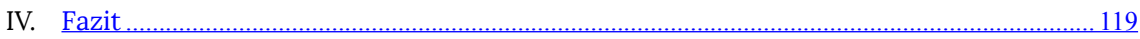

\section{Einleitung}

Der vorliegende Beitrag fokussiert sich auf den Einfluss von Corporate Social Responsibility bei Kapitalmarkttransaktionen. Der Aufsatz greift dabei einzelne Aspekte heraus, ohne einen Anspruch auf Vollständigkeit zu haben. Der Artikel berücksichtigt überdies wesentliche Entwicklungen nach der Präsentation vom 19. November 2019. 


\section{Begriff „Corporate Social Responsibility“}

Corporate Social Responsibility oder kurz CSR ist ein Schlagwort, das in den letzten Jahren einen grossen Aufschwung erfahren hat. Einleitend soll deshalb zunächst auf diesen Begriff unabhängig des Kaptialmarktes eingegangen werden.

Vorab ist festzuhalten, dass es keine Legaldefinition von Corporate Social Responsibility gibt. Sucht man in der Literatur oder im Internet nach Definitionen, so findet man unzählige Vorschläge. Deshalb sollen an dieser Stelle nur zwei Definitionen vorgestellt werden:

- Staatssekretariat für Wirtschaft SECO umschreibt auf seiner Webseite CSR wie folgt: „Die gesellschaftliche Verantwortung der Unternehmen (Corporate Social Responsibility, CSR) bezieht sich auf die Auswirkungen der unternehmerischen Tätigkeit auf Gesellschaft und Umwelt.“1

- Die Europäische Kommission umschreibt den Begriff CSR als Verantwortung von Unternehmen für ihre Auswirkungen auf die Gesellschaft. ${ }^{2}$

Diese Definitionen zeigen, dass von einem weiten Begriffsverständnis ausgegangen wird. Zahlreiche Aspekte spielen eine Rolle, wie:

- Arbeitsbedingungen, insbesondere in ärmeren Drittländern;

- Menschenrechte;

- Umwelt;

- Korruptionsprävention, fairer Wettbewerb, Verbraucherinteressen;

- Steuern (kein Transfer von Unternehmensgewinne in Steueroasen);

- Transparenz; und

- weitere Aspekte wie Berücksichtigung der Bedürfnisse der lokalen Umgebung, Einbindung lokaler Kapazitäten, Wissenstransfer, Schutz der Rechte an geistigem Eigentum sowie gute Unternehmensführung.

1 Webseite abrufbar unter <https://www.seco.admin.ch/seco/de/home/Aussenwirtschaftspolitik_Wirtschaftliche_Zusammenarbeit/Wirtschaftsbeziehungen/Gesellschaftliche Verantwortung_der_Unternehmen.html>. Ähnlich auch der Bundesrat in seinem CSR-Positionspapier und -Aktionsplan (Bundesrat, Gesellschaftliche Verantwortung der Unternehmen, Positionspapier und Aktionsplan des Bundesrates zur Verantwortung der Unternehmen für Gesellschaft und Umwelt, Bern 1. April 2015, 3 f. (nachfolgend: CSR-Positionspapier und -Aktionsplan des Bundesrates).

2 Wörtlich: „als ein Konzept, das den Unternehmen als Grundlage dient, auf freiwilliger Basis soziale Belange und Umweltbelange in ihre Unternehmenstätigkeit und in die Wechselbeziehungen mit den Stakeholdern zu integrieren." (Mitteilung der Kommission an das Europäische Parlament, den Rat, den Europäischen Wirtschafts- und Sozialausschuss und den Ausschuss der Regionen, Eine neue EU-Strategie [2011-2014] für die soziale Verantwortung von Unternehmen CSR). 
CSR geht demnach über die gesetzlichen Pflichten hinaus und möchte erreichen, dass Unternehmen "good corporate citizen“ sind.

\section{Kurzer Abriss der Geschichte von CSR}

Obwohl es bereits im 19. Jahrhundert im Rahmen der Industrialisierung Vorläufer von CSR-Aktivitäten durch Unternehmen gab, löste Howard R. Bowen mit seinem Buch „Social Responsibilities of the Businessman“ 1953 die moderne Bewegung von CSR aus. ${ }^{3}$ Darin beschreibt er, wie ein Geschäftsmann auch Ziele und Werte der Gesellschaft (society) bei seinen Entscheidungen berücksichtigen soll. Bowen wollte damit keine Kritik am Kapitalismus an sich üben, sondern sich mit den Problemen beschäftigen, welche sich aus dem Kapitalismus ergeben. Bowen war der Ansicht, dass Entscheidungen von Geschäftsleuten weitreichende Konsequenzen für die Gesellschaft haben können. Er stellte sich dabei auf den Standpunkt, dass sich die Freiheit über Entscheidungen nur dann rechtfertigen, wenn diese für das Gesamtwohl der Gesellschaft förderlich sind.

Einen richtigen Aufschwung erfuhr CSR aber erst in den 1990er Jahren im Zuge der Globalisierung. Weil Geschäftspraktiken von weltweit tätigen Unternehmen an die Öffentlichkeit gelangten, welche Menschenrechte verletzten, die Umwelt schädigten oder in anderer Weise nicht zu einer gemeinhin "guten“ Unternehmensführung gehörten, wurde der Ruf laut, dass solche Unternehmen auch eine soziale Verantwortung wahrnehmen müssten.

Als Folge dessen wurden von unzähligen internationalen non-profit Organisationen und von supranationalen Organisationen Richtlinien und/oder Prinzipien erarbeitet, welche von Unternehmen auf freiwilliger Basis befolgt werden sollten. Zu den wichtigsten gehören der UN Global Compact oder die Global Reporting Initiative („GRI“), welche weiter unten näher ausgeführt werden. ${ }^{4}$

Obwohl unverbindliche Richtlinien und Prinzipien einen ersten Schritt in die richtige Richtung darstellten, konnten diese fragwürdige Geschäftspraktiken nicht unterbinden. Deshalb wurde in den letzten Jahren die Forderung laut, dass Gesetzgeber verbindliche Regelungen erlassen sollten, welche solche Geschäftsgebaren unterbinden sollten. Das stellte die Gesetzgeber vor Herausforderungen. Während in groben Zügen ein Konsens besteht, was unter einer guten Geschäftsführung zu verstehen ist, gehen im Einzelnen die Meinungen diesbezüglich oftmals auseinander. Des Weiteren spielen sich viele

\footnotetext{
3 BOWEN R. HOWARD, Social Responsibilities of the Businessman, Williamstown Massachusetts 1953.

4 Vgl. Kapitel II.3.
} 
unerwünschte Praktiken primär ausserhalb von Europa ab, was ein staatliches Eingreifen durch europäische Gesetzgeber schwierig macht, da diese keine staatliche Hoheit ausserhalb der jeweiligen Jurisdiktion haben. Einen Ausweg ist die Regelung von Konzernmuttergesellschaften, welche regelmässig den Sitz in der EU, den USA oder der Schweiz haben. So erliess die EU eine Richtlinie, welche grössere Gesellschaften zu einer Nachhaltigkeitsberichtserstattung verpflichtet. ${ }^{5}$ Im Bereich von CSR gab es in der EU zudem weitere Vorstösse, welche insbesondere das Pariser Klimaübereinkommen ${ }^{6}$ umsetzen sollen, wie beispielsweise den Erlass eines EU Green Bonds Framework. ${ }^{7}$ In der Schweiz gibt es zurzeit keine EU ähnliche Berichterstattungspflicht, obwohl sich viele Schweizer Konzerne, welche weltweit tätig sind, einer freiwilligen Berichterstattung nach einem international anerkannten Standard unterwerfen. Hingegen ist im Zeitpunkt dieser Publikation die sogenannte Konzernverantwortungsinitiative in der Schweiz hängig, die von Unternehmen mit Sitz, Hauptverwaltung oder Hauptniederlassung in der Schweiz nicht nur eine Berichterstattung fordert, sondern auch eine Haftung für Tochtergesellschaften für Schäden vorsieht, die solche Tochtergesellschaften in Ausübung ihrer geschäftlichen Verrichtung verursachen.

\section{Heutige Rechtslage}

a) Schweiz

\section{aa) Allgemein}

Bis anhin hat der Schweizer Gesetzgeber von einer Gesetzgebung, welche spezifisch auf CSR für Konzerne mit Sitz in der Schweiz abzielt, abgesehen. Allerdings gibt es zurzeit verschiedene Vorstösse, welche CSR stärker verankern wollen. Während die einen nach wie vor auf Freiwilligkeit setzen, gibt es vermehrt auch Forderungen nach verbindlichen Regelungen, wie zum Beispiel die Konzernverantwortungsinitiative es fordert.

5 Richtlinie 2014/95/EU des Europäischen Parlaments und des Rates vom 22. Oktober 2014 zur Änderung der Richtlinie 2013/34/EU im Hinblick auf die Angabe nichtfinanzieller und die Diversität betreffender Informationen durch bestimmte grosse Unternehmen und Gruppen.

6 Klimaübereinkommen von Paris vom 12. Dezember 2015 (SR 0.814.012; nachfolgend: Pariser Klimaübereinkommen).

7 EU Technical Expert Group on Sustainable Finance, Report on EU Green Bond Standard, 18. Juni 2019, abrufbar unter <https://ec.europa.eu/info/sites/info/files/business economy euro/banking and finance/documents/190618-sustainable-finance-teg-reportgreen-bond-standard_en.pdf> (nachfolgend: EU Green Bond Framework). 
Der Bundesrat publizierte 2015 ein CSR-Positionspapier und -Aktionsplan. ${ }^{8}$ Darin formuliert er, welche Massnahmen dazu beitragen sollen, CSR auf nationaler und internationaler Ebene zu fördern. Der Bundesrat definierte dafür vier Stossrichtungen: ${ }^{9}$

- Mitgestalten der CSR-Rahmenbedingungen: Zu diesen Massnahmen gehören Aktivitäten in internationalen Organisationen wie der OECD, UNO, ILO und den Europarat sowie themen- und branchenspezifische Aktivitäten (z.B. im Bereich der Rohstoffbranche). ${ }^{10}$

- Sensibilisierung und Unterstützung der Schweizer Unternehmen: Der Bundesrat unterscheidet zwischen der allgemeinen Sensibilisierung und Unterstützung, wie zum Beispiel die Durchführung von Schulungen zu CSR, und der themenspezifischen, wozu die Dachorganisation Swiss Sustainable Finance zählt. ${ }^{11}$

- Fördern der CSR in Entwicklungs- und Transitionsländern: Bei dieser Stossrichtung möchte der Bundesrat die internationale Zusammenarbeit verstärken, um insbesondere die Wertschöpfungskette umwelt- und sozialverträglich auszugestalten. ${ }^{12}$

- Fördern der Transparenz: Für die Beurteilung der Wirkung und die Glaubwürdigkeit von CSR ist die Berichterstattung über CSR wichtig. Entsprechend möchte der Bundesrat die Nachhaltigkeitsberichterstattung sowie die Erarbeitung und Förderung von Transparenz von Instrumenten fördern, welche die Nachhaltigkeitsberichterstattung unterstützen. ${ }^{13}$

Im Jahre 2017 publizierte der Bundesrat einen Bericht zur Umsetzung des Aktionsplans. ${ }^{14}$ Der Bericht fasst die Aktivitäten des Bundes von 2015 bis 2017 zusammen. Der Bundesrat hat zusätzlich am 15. Januar 2020 ein überarbeiteter Aktionsplan 2020-2023 zur gesellschaftlichen Verantwortung der Unternehmen und zu Wirtschaft und Menschenrechten gutgeheissen. ${ }^{15}$ Dieser Aktionsplan setzt die UNO-Leitprinzipien für Wirtschaft und Menschenrechte um.

8 CSR-Positionspapier und -Aktionsplan (Fn. 1).

9 CSR-Positionspapier und -Aktionsplan (Fn. 1), 3.

10 CSR-Positionspapier und -Aktionsplan (Fn. 1), 13.

11 CSR-Positionspapier und -Aktionsplan (Fn. 1), 14 ff. und Bundesrat, Bericht des Bundesrates zum Stand der Umsetzung des Aktionsplans (Periode April 2015 bis März 2017), 11 ff. (nachfolgend: Bericht zur Umsetzung des CSR-Positionspapier und -Aktionsplan).

12 CSR-Positionspapier und -Aktionsplan (Fn. 1), $16 \mathrm{f}$.

13 CSR-Positionspapier und -Aktionsplan (Fn. 1), $17 \mathrm{f}$.

14 Bericht zur Umsetzung des CSR-Positionspapier und -Aktionsplan (Fn. 11).

15 Bundesrat, Positionspapier und Aktionsplan des Bundesrates zur Verantwortung der Unternehmen für Gesellschaft und Umwelt, Stand der Umsetzung 2017-2019 und Aktionsplan 2020-2023, Bern, 15. Januar 2020. Vgl. die offizielle Webseite dazu < https://www.napbhr.admin.ch/napbhr/de/home.html>. 
Der Bundesrat hat darin drei Schwerpunkte formuliert: (i) Kommunikation, (ii) Unterstützung für die Unternehmen und (iii) politische Kohärenz. Zu den Prinzipien formulierte er je verschiedene Massnahmen (insgesamt 35) und definiert die Zuständigkeiten. Gewisse Massnahmen beschränken sich allerdings auf die Durchsetzung des geltenden Rechts (zum Beispiel die Massnahme 1 - Regulierung der Exporte von Kriegsmaterial und von Gütern zur Internetüberwachung). Andere sind relativ vage gehalten (beispielsweise die Massnahme 3 - Förderung der UNO Leitprinzipien: UNO-Leitprinzipien bekannt machen, indem verschiedene Veranstaltungen durchgeführt werden).

In der Schweiz gibt es keine gesetzlich verankerte Pflicht, über CSR zu berichten oder gar einen eigenen Bericht zu erstellen. Im Zuge der Änderung des Obligationenrechts im Rahmen der Aktienrechtsrevision wird eine Berichterstattungspflicht im Bereich der Gewinnung von Mineralien, Erdöl und Erdgas sowie des Einschlags von Holz in Primärwäldern eingeführt. ${ }^{16}$ Die Konzernverantwortungsinitiative möchte eine Rechenschaftspflicht über die ergriffenen Massnahmen zur Verhütung von Verletzungen von Menschenrechten und Umwelt einführen, welche eventuell bereits im Rahmen der Aktienrechtsrevision ins Obligationenrecht aufgenommen werden sollte. ${ }^{17}$

\section{bb) Institutionelle Investoren im Besonderen}

In den letzten Jahren stieg der Anteil an institutionellen Investoren in Schweizer Aktiengesellschaften und damit ihre Einflussnahme stetig. ${ }^{18}$

Während CSR schon seit Längerem ein Investitionskriterium bei institutionellen Investoren war, hat es dieses in den letzten Jahren regelmässig in die Listen der meistgewichteten Investitionskriterien von institutionellen Investoren

16 Vgl. Vorentwurf zur Änderung des Obligationenrechts (Aktienrechts), abrufbar unter $<$ https://www.bj.admin.ch/bj/de/home/wirtschaft/gesetzgebung/aktienrechtsrevision14.html>

17 Vgl. Art. 101a Abs. 2 lit. b E-BV der Eidgenössischen Volksinitiative „Für verantwortungsvolle Unternehmen - zum Schutz von Mensch und Umwelt" sowie die Fahne des Ständerats vom 7. Mai 2020 zur Änderung des Obligationenrechts (Aktienrecht), Geschäftsnummer 16.077n, abrufbar unter <https://www.parlament.ch/centers/eparl/curia/2016/20160077/S2-8 D.pdf>, Art. 716a Ziff. 10 i.V.m. 716abis E-OR.

BÖCKLi Peter, Proxy Advisors: Risikolose Stimmenmacht mit Checklisten, in SZW 3/2015, 209-225, 210; BÜHLER CHRISTOPH, Ausserrechtliche Regulierungstendenzen in der Corporate Governance, Expert Fokus 1/2, 2016, 12-19, 12; Gericke Dieter/Baum Oliver, Corporate Governance: Wer ist der Governor? - Stimmrechtsberatung als Folge und Katalysator eines Paradigmenwechsels, in: SZW 4/2014, 345-361, 347; Hoch MARIEL, Proxy Advisory - eine Standortbestimmung, in SZW 5/2016, 487-494, 487. 
geschafft. Das hatte zur Folge, dass es kaum eine kotierte Gesellschaft gibt, welche keinen CSR-Bericht veröffentlicht oder zumindest ein Statement über CSR in ihrem Geschäftsbericht publiziert.

Institutionellen Investoren, insbesondere die Vorsorgeeinrichtungen, gerieten in den letzten Jahren aber auch ins Visier von Gesetzgebern: Sie sollen mit Vorgaben zu CSR in ihrer Anlagepolitik indirekt Unternehmen dazu bewegen, CSR in ihrer Geschäftstätigkeit zu integrieren. Zwar gibt es de lege lata keine gesetzlichen Vorgaben in diesem Bereich, doch sind verschiedene Vorstösse hängig, welche darauf abzielen, Vorsorgeeinrichtungen zu nachhaltigen Investitionen anzuhalten. Auf EU-Ebene gibt es eine Richtlinie, welche auf Einrichtungen der betrieblichen Altersversorgung anwendbar ist und unter anderem eine Erklärung über die Grundsätze der Anlagepolitik, insbesondere wie den Bereichen Umwelt und Soziales Rechnung getragen wird, sowie eine Auskunftspflicht gegenüber potenziellen Versorgungsanwärtern zu Fragen, ob und inwiefern Umwelt-, Klima-, soziale und Unternehmensführungsaspekte in der Anlagepolitik berücksichtigt worden sind, vorsieht. ${ }^{19}$

\section{cc) SIX Swiss Exchange}

Die SIX Exchange Regulation hat in ihrer Richtlinie betreffend Informationen zur Corporate Governance vom 20. März 2018 ein Opting In für eine Nachhaltigkeitsberichterstattung vorgesehen: ${ }^{20}$ Emittenten, welche ein Opting In im Sinne dieser Richtlinie erklärt haben, verpflichten sich, einen Nachhaltigkeitsbericht gemäss einem internationalen Standard zu erstellen. Die kurze Liste zeigt allerdings, dass sich nur ein Bruchteil der Emittenten für ein Opting In entschieden haben, obwohl viele über Nachhaltigkeit berichten. ${ }^{21}$ Die SIX Swiss Exchange führt des Weiteren eine Liste für Green Bonds sowie eine Liste für Sustainability Bonds, welche an der SIX Swiss Exchange kotiert sind. ${ }^{22}$ Die Eintragung setzt eine Climate Bonds Initiative Zertifizierung voraus. Neu führte die SIX auch eine Liste für nachhaltigkeitsgebundene Anleihen ein, die keine Zertifizierung der Climate Bonds Initiative voraussetzt.

19 Art. 30 und Art. 41(3)(c) der Richtlinie (EU) 2016/2341 des Europäischen Parlaments und des Rates vom 14. Dezember 2016 über die Tätigkeiten und die Beaufsichtigung von Einrichtungen der betrieblichen Altersversorgung (EbAV).

20 Art. 9 der Richtlinie betreffend Informationen zur Corporate Governance vom 20. März 2018.

21 Vgl. die Liste im Internet <https://www.six-group.com/exchanges/shares/companies/ sustainability reporting de.html>.

22 Vgl. für weitere Informationen Kapitel II.3.f). 
Die EU verankerte eine sogenannte nichtfinanzielle Berichterstattung mittels einer Richtlinie, welche die Mitgliedstaaten in ihrem nationalen Recht umsetzen müssen. Die massgebliche Richtlinie ist die 2014 erlassene CSR-Richtlinie, bei welcher es sich um eine Änderungsrichtlinie, die Vorschriften zur nichtfinanziellen Berichterstattung in die Bilanzrichtlinie einführt. ${ }^{23}$ Die Richtlinie war von den Mitgliedstaaten gemäss ihrem Art. 4 bis zum 6. Dezember 2016 umzusetzen; in Deutschland geschah das (verspätet) durch das sog. CSRRichtlinie-Umsetzungsgesetz vom 11. April 2017.

Im Grundsatz ist die Richtlinie anwendbar für grosse Unternehmen von öffentlichem Interesse, welche im Durchschnitt mehr als 500 Mitarbeiter beschäftigen. ${ }^{24}$ Solche Unternehmen müssen in ihrem Lagebericht eine nichtfinanzielle Erklärung aufnehmen. Als Mindestinhalt fordert die Richtlinie, dass Unternehmen über Umwelt-, Sozial- und Arbeitnehmerbelange, Achtung der Menschenrechte, Bekämpfung von Korruption sowie Bestechung berichten. Falls über einen Themenschwerpunkt nicht berichtet wird, kann das betreffende Unternehmen eine entsprechende Erklärung abgeben, weshalb darauf verzichtet wird (comply or explain). Des Weiteren besteht ein Opting Out für bestimmte Informationen, welche der Geschäftslage des Unternehmens ernsthaft schaden würden, sofern durch Nichtaufnahme kein verfälschtes Bild des Geschäftsverlaufs, des Geschäftsergebnisses, der Lage des Unternehmens sowie der Auswirkungen seiner Tätigkeit entsteht. U.E. untergräbt es die Glaubwürdigkeit eines Berichts, wenn bei „unangenehmen“ Fragen ausgewichen werden darf.

Der Bericht unterliegt einer formellen Prüfung des Abschlussprüfers oder der Prüfgesellschaft und beschränkt sich auf das Vorhandensein der nichtfinanziellen Erklärung. Entsprechend erfolgt keine materielle bzw. inhaltliche Überprüfung über deren Richtigkeit, Kohärenz und Vollständigkeit. Die Richtlinie selbst sieht zudem keine Haftung vor. Verschiedene Mitgliederstaaten der EU

„CSR-Richtlinie“: Richtlinie 2014/95/EU des Europäischen Parlaments und des Rates vom 22. Oktober 2014 zur Änderung der Richtlinie 2013/34/EU im Hinblick auf die Angabe nichtfinanzieller und die Diversität betreffender Informationen durch bestimmte grosse Unternehmen und Gruppen. „Bilanzrichtlinie“: Richtlinie 2013/34/EU des Europäischen Parlaments und des Rates vom 26. Juni 2013 über den Jahresabschluss, den konsolidierten Abschluss und damit verbundene Berichte von Unternehmen bestimmter Rechtsformen und zur Änderung der Richtlinie 2006/43/EG des Europäischen Parlaments und des Rates und zur Aufhebung der Richtlinien 78/660/EWG und 83/349/EWG des Rates. 
unterwerfen jedoch die Berichterstattung einem Haftungsregime. Die Richtlinie im Allgemeinen lässt den Mitgliedstaaten einen breiten Spielraum bei der Umsetzung. ${ }^{25}$

Art. 2 der CSR-Richtlinie sieht vor, dass die Kommission eine Orientierungshilfe für die Berichterstattung in Gestalt unverbindlicher Leitlinien veröffentlicht. Dem ist die Kommission im Juli 2017 durch die Veröffentlichung von Leitlinien für die Berichterstattung über nichtfinanzielle Informationen nachgekommen ${ }^{26}$ In einer Mitteilung zum Investitionsplan für ein zukunftsfähiges Europa vom 14. Januar 2020 legte die Kommission ehrgeizige Ziele fest, welche die EU zu einer fairen und wohlhabenden Gesellschaft mit einer ressourceneffizienten und wettbewerbsfähigen Wirtschaft umwandeln soll, in der es 2050 keine Netto-Treibhausgasessmissionen mehr gibt. Darin hat sie auch angekündigt, im dritten Quartal 2020 eine neue Strategie für ein nachhaltiges Finanzwesen zu präsentieren und in diesem Rahmen auch die CSR-Richtlinie überprüfen zu wollen. ${ }^{27}$

\section{c) Nicht verbindliche Richtlinien}

Wie bereits erwähnt gibt es heute unzählige Standards für eine nachhaltige Berichterstattung für Unternehmen. $\mathrm{Zu}$ den bedeutesten gehören die GRI oder der UN Global Compact, weshalb sie an dieser Stelle kurz vorgestellt werden sollen.

Der UN Global Compact wurde vor rund zwanzig Jahren von der UNO gegründet. Unternehmen, welche die zehn Prinzipien des UN Global Compact einhalten, können dem Compact beitreten. Die zehn Prinzipien sind vage gehalten und fordern unter anderem die Einhaltung von Menschenrechten, die Unterlassung von Zwangsarbeit, eine vorsorgende Haltung gegenüber Umweltgefährdungen sowie das Eintreten gegen alle Arten von Korruption. Unterneh-

25 Für eine vertiefte Auseinandersetzung mit der Umsetzung der CSR-Richtlinie: HECKENDORN URSCHELER LUKAS/BAST JOHANNES et al., Umsetzung der Richtlinie 2014/95/EU, E-Avis ISDC 2017-12 (verfügbar unter <https://www.isdc.ch/media/1378/e-2017-12-16-173-richtlinie-2014-95-gz.pdf>.

26 Europäische Kommission, Mitteilung der Kommission, Leitlinien für die Berichterstattung über nichtfinanzielle Informationen (Methode zur Berichterstattung über nichtfinanzielle Informationen) vom 5. Juli 2017 (2017/C215/01).

27 Mitteilung der Kommission an das Europäische Parlament, den Rat, den Europäischen Wirtschafts- und Sozialausschuss und den Ausschuss der Regionen. Investitionsplan für ein zukunftsfähiges Europa. Investitionsplan für den europäischen Grünen Deal vom 17. Februar 2020 (COM[2020] 21 final). 
men sind gehalten, jährlich Bericht darüber zu erstatten. ${ }^{28}$ In der Schweiz gibt es ein offizielles Netzwerk des UN Global Compact, welches den UN Global Compact in der Schweiz fördern soll. ${ }^{29}$ Die Einhaltung dieser Prinzipien wird aber nicht vom UN Global Compact überprüft. Obwohl die Webseite des UN Global Compact diejenigen Unternehmen auflistet, welche nicht rapportieren, fehlt ein eigentliches Sanktionsregime.

Die GRI ist eine in Amsterdam basierte unabhängige Organisation, welche zusammen mit den verschiedenen Anspruchsgruppen eine Richtlinie für Nachhaltigkeitsberichterstattung erarbeitet hat. Der GRI Standard ist sehr viel ausführlicher als die Prinzipien des UN Global Compact. Er ist eingeteilt in einen Grundlagenteil (GRI 101), einen Teil, welcher sich mit der generellen Offenlegung beschäftigt (GRI 102), einen Teil über den Management Approach (GRI 103) sowie drei Teile über ökonomische, Umwelt- und soziale Belange (GRI 200, 300 und 400). Ein Unternehmen, kann wählen, ob es das Reporting nur auf spezifisch vorgegebene Themen beschränken möchte (core) oder umfassend berichten möchte (comprehensive). Auch die GRI sieht weder ein Überwachungs- noch ein Sanktionsregime bei Nichteinhaltung vor. ${ }^{30}$

Des Weiteren wurden auch Richtlinien für Emissionen, wie der ICMA Green Bonds Standard oder die Climate Bonds Initiative, entwickelt. ${ }^{31}$ Solche Richtlinien enthalten Vorgaben, welche sich auf eine Emission eines Instruments (zum Beispiel eine Anleihe) beschränken. Diese werden im II. Kapitel ausführlicher behandelt. ${ }^{32}$

\section{ESG Ratings}

Dieses letzte Einführungskapitel beschäftigt sich mit einem der CSR nahen Thema: ESG Ratings. ESG steht für Environmental, Social and Governance. Unter Environmental (Umwelt) werden Kriterien wie der Klimawandel, die Reduktion von Abfall oder die Umweltverschmutzung verstanden. Social (Soziales) referenziert auf Kriterien wie Arbeitsbedingungen, Diversität,

Webseite des UN Global Compact abrufbar unter <https://www.unglobalcompact.org/> . Die zehn Prinzipien sind abrufbar unter $<$ https://www.unglobalcompact.org/what-is-gc/ mission/principles>.

29 Vgl. die offizielle Webseite <https://www.globalcompact.ch/>.

30 Vgl. die offizielle Webseite <https://www.globalreporting.org/Pages/default.aspx>

31 Vgl. die Green Bond Principles der International Capital Market Association, verfügbar unter <https://www.icmagroup.org/green-social-and-sustainability-bonds/green-bondprinciples-gbp/> und die Climate Bonds Initiative, verfügbar unter $<$ https://www.climatebonds.net/>.

32 Vgl. Kapitel II.3. 
Gesundheit oder Sicherheit am Arbeitsplatz. Governance (Unternehmensführung) schliesslich knüpft an Themen wie Geschäftsethik, Korruption oder Vergütungspolitik an.

ESG Ratings sollen institutionellen Investoren als Unterstützungshilfe bei ihren Entscheidungen zu nachhaltigen Investitionen dienen. So erstaunt es nicht, dass gerade in den letzten Jahren das Angebot an solchen Ratings sprunghaft angestiegen ist. Allerdings zeichnet sich in letzter Zeit auch ein Konsolidierungsprozess $\mathrm{ab}^{33} \mathrm{Zu}$ den namhaften ESG-Ratings zählen ISS-ESG Rating, ESG Impact Ratings von Inrate oder Vigeo-EIRIS Rating.

ESG Ratings können aber auch für eine spezifische Emission vergeben werden: So bewertet Moody's in ihrem Moody's Green Bond Assessment (GBA) die Organisation, die Verwendung des Emissionserlöses, die Offenlegung des Emissionserlöses, die Verwaltung des Emissionserlöses sowie die fortlaufende Berichterstattungspflicht und Offenlegung von sogenannten "grünen“ Emissionen. $^{34}$

Der Vollständigkeit halber sei angemerkt, dass ESG keine Credit Ratings sind; mithin wird nichts über die Bonität des jeweiligen Emittenten und/oder eines emittierten Instruments ausgesagt.

\section{Emissionen}

\section{I. Überblick}

Der Schweizer Gesetzgeber sieht keine rechtliche Sonderbehandlung vor für Emissionen, welche CSR-Kriterien berücksichtigen. Allerdings sind verschiedene Vorstösse in der Schweizer Politik hängig, welche in diese Richtung zielen. So beschäftigt sich beispielsweise das Positionspapier des Bundesrates zur Verantwortung der Unternehmen für Gesellschaft und Umwelt mit dieser Problematik. ${ }^{35}$ Das Postulat, „Bremsen lösen bei nachhaltigen Finanzprodukten“ möchte nachhaltige Finanzprodukte attraktiver machen, indem gewisse Steu-

\footnotetext{
33 Zum Beispiel fusionierten Vigeo und EIRIS und Oekom war von ISS gekauft worden.

34 Moody's Investors Services, Green Bonds Assessment (GBA), 30. März 2016, 3 ff.

35 Vgl. CSR-Positionspapier und -Aktionsplan des Bundesrates (Fn. 1), insbesondere 13 ff.
} 
ern wie Verrechnungssteuer wegfallen. ${ }^{36}$ Die Arbeitsgruppe zu Sustainable Finance, welche vom Bundesrat eingesetzt worden ist, soll eine Strategie entwickeln, wie nachhaltige Finanzierungen wettbewerbsfähiger ausgestaltet werden können. ${ }^{37}$

Die SIX Swiss Exchange möchte mit einer Liste von Green Bonds nachhaltige Finanzprodukte transparenter machen. Deren Liste ist allerdings bescheiden. ${ }^{38}$

Grosses hat die EU mit ihrer EU Taxonomie für nachhaltige Finanzierung und dem Green Bond Standard vor. Diese werden in einem separaten Kapitel weiter unten behandelt. ${ }^{39}$

Verschiedene internationale Organisationen haben Leitlinien herausgegeben, welche als Richtschnur für Emittenten bei nachhaltigen Finanzierungen dienen soll: Namentlich zählen dazu die ICMA Principles für Green Bonds, Social Bonds oder Sustainability Bonds oder die Climate Bonds Initiative. Diese werden aufgrund ihrer Tragweite ebenfalls in einem eigenen Abschnitt weiter unten behandelt. ${ }^{40}$

\section{EU Taxonomie für nachhaltige Finanzierung}

Im Juni 2019 stellte die EU Technical Expert Group on Sustainable Finance der EU in einem vorläufigen Bericht eine Taxonomie für eine nachhaltige Finanzierung vor. Die Taxonomie enthält für eine Vielzahl von Sektoren jeweils sehr ausführliche und branchenspezifische Beschreibungen, welche mittels Grenzwerten definieren, was unter einer nachhaltigen Finanzierung zu verstehen ist. Die Idee war, dass diese Taxonomie in eine EU-Verordnung umgegossen und weitere Richtlinien angepasst werden sollen, um für nachhaltige Finanzie-

36 Kommission für Umwelt, Raumplanung und Energie SR, Postulat 19.3951 „Bremsen lösen bei nachhaltigen Finanzprodukten“, eingereicht am 27. Juni 2019; dieselbe, Postulat 19.3966, „Klimaverträgliche Ausrichtung und Verstärkung der Transparenz der Finanzmittelflüsse in Umsetzung des Übereinkommens von Paris“, eingereicht am 16. August 2019; dieselbe, Postulat 19.3950, „Nachhaltigkeit fördern dank zeitgemässen Anlagerichtlinien“, eingereicht am 26. Juni 2019.

37 Vgl. Medienmitteilung vom 26. Juni 2019, verfügbar unter $<$ https://www.admin.ch/gov/ de/start/dokumentation/medienmitteilungen.msg-id-75599.html>.

38 Vgl. für weitere Informationen Kapitel II.3.f).

39 Vgl. Kapitel II.2 und II.3.e).

$40 \quad$ Vgl. Kapitel II.3. 
rungen einheitliche Rahmenbedingungen in der ganzen EU zu schaffen. Damit soll dem Kapitalmarkt geholfen werden, Investitionsmöglichkeiten, welche zur Abschwächung des Klimawandels beitragen, einfacher zu identifizieren. ${ }^{41}$

Die Implementation soll in fünf Schritten erfolgen: ${ }^{42}$

- Identifikation von Aktivitäten einer Gesellschaft, welche für eine Finanzierung geeignet sein können;

- Analyse, ob die betreffende Aktivitäten die relevanten Screening Kriterien erfüllen;

- Analyse, ob DNSH (do not significant harm) Kriterien erfüllt sind; ${ }^{43}$

- Durchführung einer Due Diligence, um sicherzustellen, dass minimale soziale Kriterien, welche von der Taxonomie vorgegeben sind, eingehalten werden; und

- Berechnung der Kompatibilität mit der Taxonomie und Publikation auf Stufe des Finanzprodukts.

Des Weiteren erreichte das Europäische Parlament mit dem Rat im Dezember 2019 eine Einigung über neue Kriterien für die Definition von nachhaltigen wirtschaftlichen Aktivitäten in Form einer Verordnung über nachhaltige Finanzierung. Der Entwurf wurde im Januar 2020 von den Ausschüssen für Wirtschaft und Währung sowie für Umweltfragen, Volksgesundheit und Lebensmittelsicherheit genehmigt. Verschiedene Kriterien wurden in einem Entwurf für eine Verordnung festgelegt. ${ }^{44}$ Die Verordnung umfasst insgesamt 17 Artikel und verzichtet auf Definitionen, welche Aktivitäten kategorisieren und Schwellenwerte festsetzen und ist auch technologieneutral. Eine wirtschaftliche Aktivität sollte dabei zum Erreichen eines oder mehreren festgelegten Zielen dienen, wobei diese dabei keines der anderen Ziele erheblich gefährden darf. Als Ziele nennt der Entwurf folgende Kriterien: (i) Klimaschutz,

41 EU Technical Expert Group on Sustainable Finance, Taxonomy Technical Report, 18. Juni 2019, abrufbar unter <https://ec.europa.eu/info/sites/info/files/business economy_euro/banking_and_finance/documents/190618-sustainable-finance-teg-reporttaxonomy en.pdf> (nachfolgend EU Expert Group Technical Report Sustainable Finance).

42 Vgl. EU Expert Group Technical Report Sustainable Finance (Fn. 41), 62.

43 Damit gemeint ist, dass jede Aktivität, welche zum Klimaschutz beitragen soll, nicht wesentlich der Klimawandelanpassung und anderen vier ökologischen Zielen (nachhaltige Verwendung und Schutz von Wassers und von Meeresressourcen, Übergang in eine Kreislaufwirtschaft, Verschmutzungsprävention und -kontrolle sowie Schutz und Wiederherstellung von Biodiversität und Ökosystemen) erheblich gefährden darf.

44 European Commission, Proposal for a Regulation of the European Parliament and of the Council on the establishment of a framework to facilitate sustainable investment, COM/ 2018/353 final, 24. Mai 2018, abrufbar unter <https://eur-lex.europa.eu/legal-content/ EN/TXT/?uri=CELEX:52018PC0353>. 
(ii) Klimawandelanpassung, (iii) nachhaltige Verwendung und Schutz von Wasser und Meeresressourcen, (iv) Übergang in eine Kreislaufwirtschaft, (v) Verschmutzungsprävention und -kontrolle sowie (vi) Schutz und Wiederherstellung von Biodiversität und Ökosystemen. Während es sicherlich begrüssenswert ist, dass der Entwurf der Verordnung schlank ausfiel, wird sich zeigen müssen, ob sie genügend konkret ist, um ein allfälliges Greenwashing zu verhindern, weil die Grundsätze nicht genügend konkret festgelegt wurden. Die EU möchte einem Greenwashing vorbeugen, indem sie detaillierte Offenlegungsvorschriften vorsieht, die im Entwurf vorliegen.

Im März 2020 erschien der finale Bericht der EU Technical Expert Group on Sustainable Finance. ${ }^{45}$ Dieser berücksichtigt die oben genannte Verordnung über nachhaltige Finanzierung und greift insbesondere deren sechs Ziele auf. Eine Liste mit den technischen Einzelheiten ist in einem Anhang zum Bericht enthalten. ${ }^{46}$ Deren Länge und Detaillierungsgrad sind erschlagend: Auf 593 Seiten werden für verschiedene Branchen, welche sich wiederum in Unterkategorien unterteilen, technische Kriterien aufgelistet und erklärt, welche Tätigkeiten als nachhaltig gelten. Für potentielle Emittenten, die sich diesen Regeln unterwerfen möchten, dürfte dies zu einem nicht unerheblichen Mehraufwand führen. Aber auch auf der Investorenseite, die wissen möchte, welchen Standards die neue Taxonomie einführt, dürfte der Detaillierungsrad abschrecken, sich eingehender mit dieser Taxonomie zu beschäftigen.

\section{Anleihen, insbesondere Green Bonds}

\section{a) Einführung}

Im Grundsatz kann jedes Finanzprodukt mit CSR verbunden werden, vorausgesetzt natürlich, dass dieses der CSR dient. Verschiedene internationale Standards unterscheiden zwischen verschiedenen Kategorien, die jedoch schlussendlich für die Nachhaltigkeit an sich ohne Belang sind. ${ }^{47}$

45 EU Technical Expert Group on Sustainable Finance, Technical Report - Taxonomy: Final report of the Technical Expert Group on Sustainable Finance, 9. März 2020, abrufbar unter $<$ https://ec.europa.eu/info/sites/info/files/business_economy_euro/banking_and finance/documents/200309-sustainable-finance-teg-final-report-taxonomy_en.pdf>.

46 EU Technical Expert Group on Sustainable Finance, Taxonomy Report: Technical Annex - Updated methodology \& Updated Technical Screening Criteria, 9. März 2020, abrufbar unter <https://ec.europa.eu/info/sites/info/files/business economy euro/banking and_finance/documents/200309-sustainable-finance-teg-final-report-taxonomy-annexes_en.pdf>.

47 Vgl. ICMA, Green Bond Principles, Ausgabe 6.2018, Appendix I und Climate Bonds Standard, Version 2.1, 10. 
ICMA, deren Principles in der Praxis eine wichtige Rolle spielen, unterscheidet zwischen drei verschiedenen Anleihenskategorien, abhängig vom Nachhaltigkeitszweck der jeweiligen Anleihe: ${ }^{48}$

- Green Bonds: Die mit Abstand am bekanntesten Kategorie, (re-)finanziert ökologische Projekte;

- Social Bonds: Dieser Typ von Anleihen (re-)finanziert soziale Projekte; und

- Sustainability Bonds: Erfüllt eine Anleihe sowohl die Kriterien eines Green Bonds als auch eines Social Bonds, bezeichnet ICMA diese als Sustainability Bonds.

Kürzlich gab die ICMA zudem weitere Principles heraus, nämlich die Sustainability-Linked Bond Principles. Emittenten, welche für eine Emission diesen Principles folgen, müssen nachhaltige Ziele formulieren, deren Einhaltung mittels Leistungskennzahlen (key performance indicators; KPI) messbar sein müssen. Im Gegensatz zu den oben dargestellten Principles ist bei diesem Standard nicht die Verwendung des Emissionserlöses massgeblich, sondern die Erreichung der vordefinierten Ziele.

\section{b) Involvierte Parteien}

Zusätzlich zu denjenigen Protagonisten, die bei Kapitalmarkttransaktionen regelmässig dabei sind, kommen bei nachhaltigen Finanzierungen typischerweise weitere Parteien hinzu, weshalb an dieser Stelle kurz darauf eingegangen werden soll.

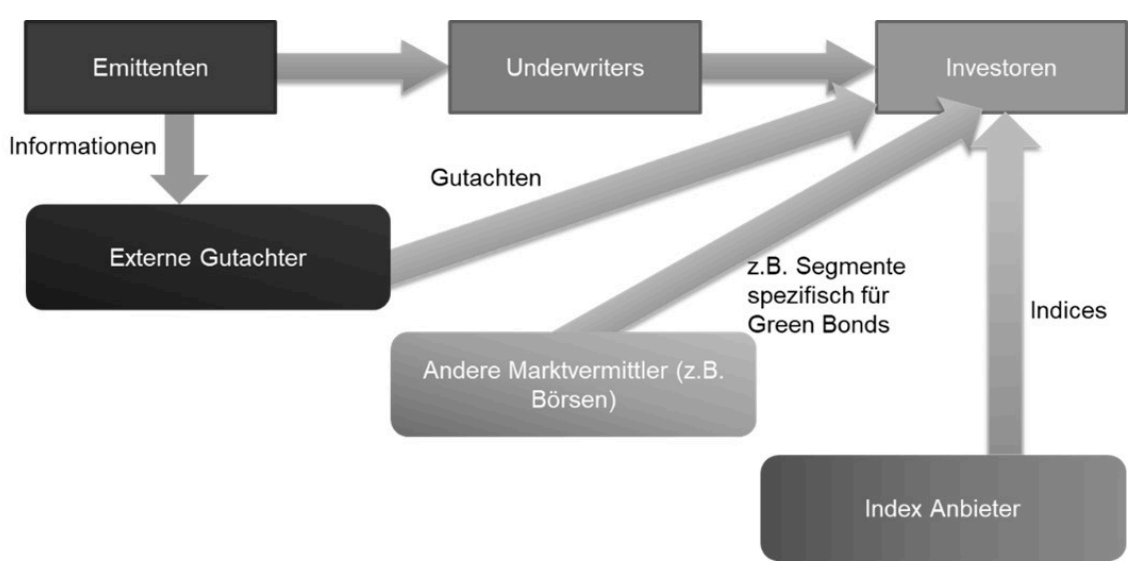

Vgl. ICMA, Green Bond Principles, Ausgabe 6.2018, Appendix I und Climate Bonds Standard, Version 2.1, 10 . 
Wie bei jeder Emission gibt ein Emittent Anleihen - in diesem Fall Green Bonds - aus, welche er typischerweise mittels Banken, welche als Underwriters und/oder Managers fungieren, bei Investoren platziert.

Bei Green Bonds werden regelmässig externe Gutachter von Emittenten beauftragt, zu bestätigen, dass der jeweilige Green Bond den anwendbaren Richtlinien (zum Beispiel ICMA Green Bonds Principles oder Climate Bonds Initiative) entspricht. Solche Gutachten werden zusammen mit den übrigen Dokumenten veröffentlicht und sollen den Green Bonds höhere Glaubwürdigkeit verleihen.

Je nachdem, an welcher Börse die Anleihe kotiert wird, gibt es Index Anbieter, welche Green Bonds in einem speziellem Green Bonds oder ähnliches Segment indexieren. ${ }^{49}$ Verschiedene Börsen unterstützen ebenfalls Green Bonds, indem sie diese in einem separaten Segment kotieren oder separate Listen führen. ${ }^{50}$

\section{c) ICMA Principles}

Die International Capital Market Association ist eine gemeinnützige Organisation mit Sitz in der Schweiz, deren Mitglieder primär am Kapitalmarkt tätig sind. 2014 gab die ICMA erstmals Green Bond Principles heraus, welche im Juni 2018 überarbeitet wurden. Die Green Bond Principles können freiwillig befolgt werden und sollen die Integrität des Green Bonds Marktes stärken. Der Fokus der Green Bond Principles liegt auf der Offenlegung und der Berichterstattung.

Die ICMA Green Bond Principles listen vier Prinzipien auf:

- Verwendung des Emissionserlöses: Der Emissionserlös sollte eindeutig einem grünen Projekt zuordenbar sein. Die grünen Projekte sollen dabei eindeutig dem Umweltschutz dienen und, sofern möglich, quantifiziert werden. Die Principles listen verschiedene Kategorien auf, welche als grüne Projekte qualifiziert werden können: Mögliche grüne Projekte können die Reduktion des Klimawandels, die Konservierung natürlicher Ressourcen oder der Biodiversität oder die Verhinderung der Umweltverschmutzung sein.

49 Zum Beispiel die London Stock Exchange (vgl. <https://www.lseg.com/green>).

50 Die Londoner Börse kennt gleich mehrere: FTSE Green Revenues Index Series, FTSE4Good Index Series, FTSE Environmental Markets Index Series oder FTSE ex Fossil Fuels Index Series. Die SIX Swiss Exchange führt eine Liste mit Green Bonds, vgl. Fn. 55. 
- Prozess für Projektevaluation und -selektion: Der Emittent eines Green Bonds soll den Prozess für die Auswahl des zu finanzierenden grünen Projekts beschreiben. Der Emittent soll dabei (i) die nachhaltigen Ziele, (ii) das Auswahlverfahren für die grünen Projekte und (iii) allfällige damit zusammenhängende Kriterien (zum Beispiel auch Ausschlusskriterien) und andere angewandte Prozesse darlegen. Die ICMA hält die Emittenten an, einen hohen Standard an Transparenz anzuwenden.

- Management des Erlöses: Der Erlös sollte eindeutig dem betreffenden grünen Projekt zugeordnet werden können. Die Ausscheidung des Erlöses in einen Sub-Account oder ein Sub-Portfolio stellen geeignete Massnahmen für eine eindeutige Zuordenbarkeit dar. Empfohlen wird zudem, dass ein externer Prüfer die Verwendung des Erlöses prüft.

- Berichterstattung: Informationen über die Verwendung des Emissionserlöses und eine regelmässige Berichterstattung sollen Investoren helfen, nachverfolgen zu können, wie der Erlös verwendet wird. Dabei sollen, wenn möglich, sowohl qualitative als auch quantitative Kriterien verwendet werden. Die zugrundeliegenden Annahmen gehören ebenfalls zu einer transparenten Berichterstattung. Die Berichterstattung sollte auch den zu erwartenden Einfluss auf das Projekt beschreiben.

Ein Green Project Mapping soll Emittenten helfen, ihr Projekt in die ICMA Principles besser einbetten zu können und beinhaltet auch eine Tabelle, welche summarisch die Green Bonds mit anderen Standards vergleicht. ${ }^{51}$

Die ICMA empfiehlt, einen externen unabhängigen Prüfer heranzuziehen. Ein Prüfer kann dabei folgende Prüfungshandlungen vornehmen:

- Zweitgutachten: Eine Institution mit Expertise im Bereich Umweltschutz kann ein Zweitgutachten ausstellen, welches die Einhaltung der Green Bond Principles bestätigt.

- Überprüfung: Ein Emittent kann eine unabhängige Überprüfung erhalten, welche typischerweise den Prozess und/oder Umweltkriterien überprüft. Die Überprüfung kann die Einhaltung von internen oder externen Kriterien beinhalten. Sie kann sich auch auf die Verwendung des Emissionserlöses, die Zuteilung des Erlöses eines Green Bonds etc. beinhalten.

- Zertifizierung: Ein Emittent kann seinen Green Bond mit einem anerkannten Label zertifizieren lassen.

51 ICMA Green Project Mapping, June 2019, abrufbar unter <https://www.icmagroup.org/ assets/documents/Regulatory/Green-Bonds/June-2019/Green-Projects-MappingDocument-100619.pdf>. 
- Green Bond Scoring/Rating: Ein Emittent kann überdies seinen Green Bond einem Green Bond Framework oder ein wesentliches Merkmal, wie die Verwendung des Emissionserlöses, durch eine qualifizierte Drittpartei gemäss einer anerkannter Methodologie evaluiert oder beurteilt haben.

\section{d) Climate Bonds Initiative}

Die Climate Bonds Initiative ist eine internationale gemeinnützige Organisation, die in England und Wales registriert ist. Sie setzt sich dafür ein, dass möglichst viele Green Bonds emittiert werden, um einen Beitrag zum Erreichen des Pariser Klimaübereinkommens beizutragen. Entsprechend müssen alle Anleihen das Pariser Klimaübereinkommen einhalten. ${ }^{52}$

Die Climate Bonds Initiative verwendet folgende Taxonomie:
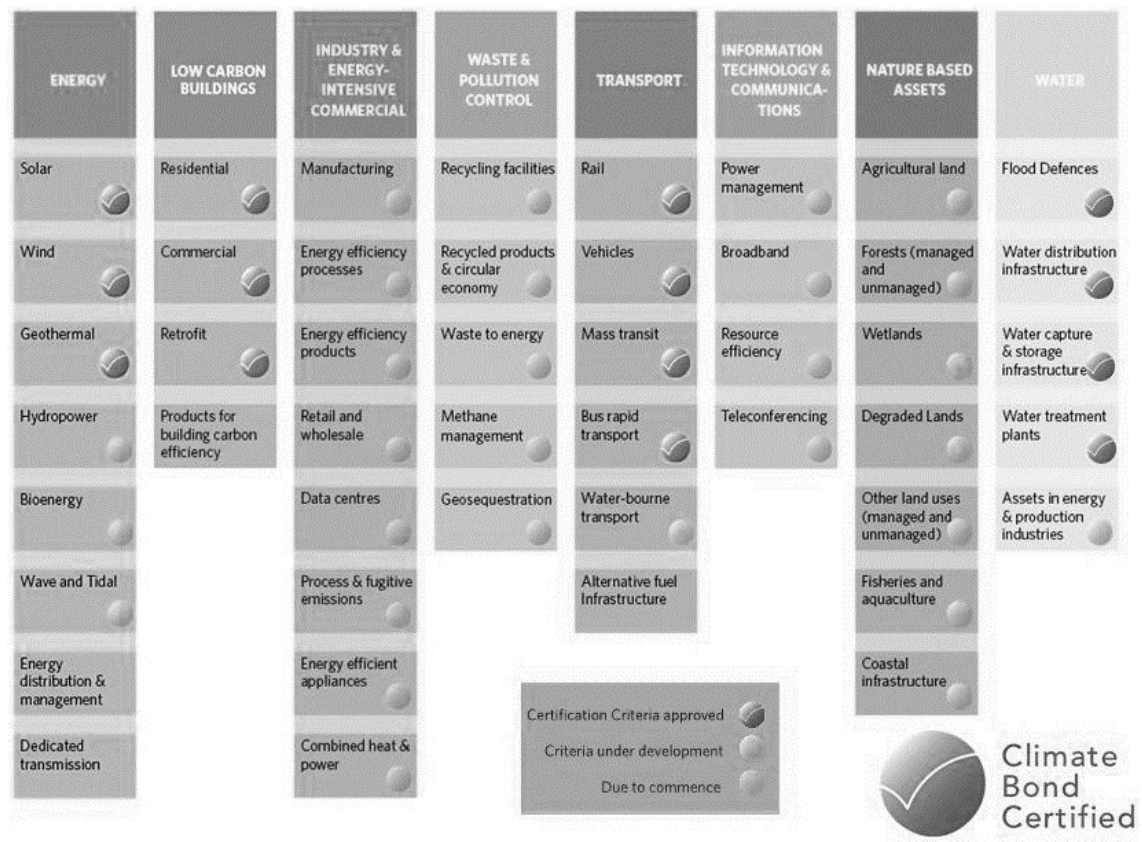

Quelle: Climate Bonds Initiative.

52 Vgl. die Beschreibung auf der Webseite der Climate Bonds Initiative $<\underline{\text { https: //www.climate- }}$ bonds.net/about>. 
Die Taxonomie zeigt auf, welche Kategorien für einen Emittenten zur Verfügung stehen, möchte er eine Anleihe gemäss der Climate Bonds Initiative ausgeben. Die Taxonomie wird ständig erweitert. Der Chart zeigt auf, welche zusätzlichen Kategorien in den nächsten Jahren voraussichtlich zertifizierbar sein werden.

Die Climate Bonds Initiative besteht aus einem Climate Bonds Standard und einem Certification Scheme. Anders als die ICMA Principles verlangt die Climate Bonds Initiative eine Zertifizierung. Der Zertifizierungsprozess ist in zwei Phasen aufgeteilt: (i) vor der Ausgabe die Überprüfung des Prozesses zur Emittierung der Anleihe, wie die Auswahl der Projekte, und (ii) nach der Ausgabe die Überprüfung der Verpflichtung des Emittenten, insbesondere ob die Zuteilung des Emissionserlöses korrekt erfolgt ist und der Berichterstattungspflicht nachgelebt wird.

Um den Climate Bonds Standard einzuhalten, muss ein Emittent sowohl vor als auch nach der Ausgabe verschiedene Voraussetzungen erfüllen, deren Wichtigsten sind:

Vor der Ausgabe:

- Die Projekte, die mit dem Erlös der Projekte (re-)finanziert werden sollen, müssen die Anforderungen des Climate Bonds Standard (sog. Climate Bonds Taxonomy) erfüllen;

- Der Emittent muss intern einen Prozess für die Rückverfolgung der Verwendung des Erlöses und das Management des nicht allozierten Erlöses aufsetzen; und

- Der Emittent ist angehalten, den Verwendungszweck und die beabsichtigte Berichterstattung (Intervall und Name des Prüfers) vorab bekanntzugeben.

Nach der Ausgabe:

- Der Climate Bonds Standard verlangt vom Emittenten, dass er über einen Entscheidungsprozess verfügt, welcher sicherstellt, dass die ausgewählten Projekte auch nach der Ausgabe dem Standard entsprechen;

- Der Erlös ist auszuscheiden und seinem Zweck zuzuführen; und

- Der Emittent soll die angekündigte Berichterstattung umsetzen. Bei der Berichterstattung soll er bei quantitativen Aussagen die unterliegenden Annahmen publizieren. 


\section{e) EU Green Bond Standard (de lege ferenda)}

Die EU beabsichtigt die Einführung eines freiwilligen EU Green Bond Standards. Damit sollen nachhaltige Anleihen für Investoren leichter identifizierbar sein und Hürden abgebaut werden.

Ein EU Green Bond soll ein grünes Projekt im Sinne der EU Taxonomie ${ }^{53}$ (re-)finanzieren. Dabei knüpft die EU an die heutige Praxis an. So muss das Projekt in einem sogenannten "Green Bond Framework“, welches u.a. das zu finanzierende Projekt und die Verwendung des Emissionserlöses beinhaltet, beschrieben werden. Ebenfalls vorgesehen sind ein sogenanntes Allocation Reporting und ein Impact Reporting. Während ersteres die Allozierung des Verwendungserlöses beschreibt, befasst sich das Impact Reporting mit der Auswirkung, dem Impact, welches das zu finanzierende Projekt hat. Ein externer Prüfer soll vor der Emission überprüfen, ob das zu finanzierende Projekt dem EU Green Bond Standard entspricht. Nach der Emission erstreckt sich die Prüfung auf die korrekte Allozierung des Emissionserlöses.

Im März 2020 erschien der Usability Guide für den vorgeschlagenen EU Green Bond Standard. ${ }^{54}$ Dieser erklärt anhand von Fragen, wie das EU Green Bond Framework zu verstehen und zu benutzen ist. Ein Template soll einen Emittenten schrittweise durch den Prozess führen.

\section{f) Umsetzung in der Schweiz}

Wie bereits festgehalten wurde, besteht keine spezifische gesetzliche Regelung für Green Bonds in der Schweiz. Die bestehende gesetzliche Regelung des Bundesgesetzes über die Finanzdienstleistungen vom 15. Juni 2018 („FIDLEG“) kann aber im Kontext von Green Bonds zusätzliche Offenlegungspflichten herbeiführen. Das FIDLEG hält nämlich fest, dass wesentliche Risiken offengelegt werden müssen. Im Rahmen der Ausgabe eines Green Bonds könnten dies beispielsweise die nicht korrekte Allozierung des Emissionserlöses sein, die nicht zu einer vorzeitigen Rückzahlung führen könnte.

Die SIX Swiss Exchange führt eine Liste mit Green Bonds, kennt aber weiter keine spezifische Regelung für Green Bonds. Neu kam auch eine Liste für

53 
Sustainability Bonds hinzu. Die Liste der Green Bonds fällt aber im Vergleich zum Volumen bescheiden aus. So haben nur gerade 22 Emittenten $^{55}$ eine oder mehrere Green Bonds an der SIX Swiss Exchange kotiert. Bei den Sustainability Bonds ist es sogar nur eine Anleihe, welche aufgeführt ist. ${ }^{56}$ Kurz vor Druck kam zudem eine Liste für Nachhaltigkeitsgebundene Anleihen (SustainabilityLinked Bonds) dazu. Aufgeführt ist der Sustainability-Linked Bond der Novartis, welcher die erste nachhaltigkeitsgebundene Anleihe im Gesundheitswesen ist.

Emittenten, welche einen Green Bond an der SIX Swiss Exchange kotieren, publizieren in der Regel ein Green Bond Framework (Rahmenbedingungen), das die zu finanzierenden Projekte beschreibt. Die übrige Dokumentation entspricht weitestgehend derjenigen einer „gewöhnlichen“ Anleihe.

Die Emissionsbedingungen eines Green Bonds unterscheiden sich regelmässig nicht von denjenigen anderer Anleihen. Insbesondere sehen sie keine vorzeitige Rückzahlung vor, wenn die Voraussetzungen des Green Bonds nicht mehr gegeben sind (sog. green default). Dies wird zuweilen auch kritisiert, da somit keine tatsächliche Kontrolle über die Verwendung des Emissionserlöses gewährleistet wird und letztendlich auch die Gefahr von Greenwashing besteht. ${ }^{57}$

\section{g) Fallbeispiel}

Anhand eines Fallbeispiels soll im Nachfolgenden aufgezeigt werden, welche Rechtsbehelfe einem Anleihensinhaber bei einem Green Default (nicht) zur Verfügung stehen:

Eine Gesellschaft gibt einen Green Bond zwecks Finanzierung eines grünen Projekts (zum Beispiel dem Betrieb einer Solaranlage) aus. Dazu erstellt er ein Green Bond Framework, welches das Projekt beschreibt, und einen Prospekt im Rahmen des öffentlichen Angebots. Der Green Bond wird von einem externen Prüfer zertifiziert, welcher bestätigt, dass die Anleihe dem Climate Bonds

55 Stand Ende April 2020.

56 Vgl. <https://www.six-group.com/exchanges/bonds/sustainability/sustainability bonds_list_de.html>.

57 European Commission, Study on the potential of green bond finance for resource-efficient investments, 24. November 2016, 40 f., abrufbar unter <https://op.europa.eu/en/publication-detail/-/publication/5a95e1b0-dc82-11e6-ad7c-01aa75ed71a1>; WEHNERT ALEX, Greenwashing blendet Fondsanleger - mit schweren Folgen, NZZ vom 14. September 2019, abrufbar unter <https://www.nzz.ch/finanzen/fonds-und-vorsorge-greenwashing-blendet-anleger-ld.1505985>. 
Standard genügt. Die Anleihe wird auch noch von einer Rating Agentur mit Bestnoten bewertet. Nach der Ausgabe stellt sich heraus, dass der Erlös nicht für ein grünes Projekt, wie vorab angekündigt, verwendet wird.

Welche Rechtsbehelfe hat ein Anleihensinhaber in einem solchen Fall? ${ }^{58}$

Gegen einen Emittenten wären folgende Rechtsbehelfe zu prüfen:

- Prospekthaftung unter OR (Art. $752 \mathrm{aOR}$ ):

Unter dem alten Recht, welches bis zum 31. Dezember 2019 in Kraft war, konnte sich jeder für den entstandenen Schaden haftbar machen, wenn im Rahmen der öffentlichen Ausgabe von Anleihen in Emissionsprospekten oder ähnlichen Mitteilungen unrichtige, irreführende oder den gesetzlichen Anforderungen nicht entsprechende Angaben gemacht oder verbreitet worden waren, sofern diese Person absichtlich oder fahrlässig bei der Erstellung mitgewirkt hat. Vorliegend handelt es sich um ein öffentliches Angebot einer Anleihe, wofür ein Prospekt erstellt wurde.

Die Natur der Prospekthaftung ist umstritten: In der Lehre wird sowohl deliktische, vertragliche Haftung als auch Vertrauenshaftung vertreten..$^{59}$ Die Natur hat Auswirkungen auf die Beweislast. Die Unterscheidung hat aber für den vorliegenden Fall keine grosse Auswirkung auf das Ergebnis, wie sich zeigen wird.

Legitimation: $\mathrm{Zu}$ einer Klage berechtigt bzw. aktivlegitimiert sind nach dem Gesetzestext in erster Linie Erwerber des besagten Instruments. Dabei ist nicht nur der Ersterwerber (Zeichner) sondern auch ein späterer Käufer der Green Bonds mitumfasst, sofern dieser beweisen kann, dass die Angaben im Prospekt kausal für seinen Kaufentscheid waren. ${ }^{60}$ Die Klage kann sich gegen alle Personen richten, welche bei der Erstellung Emissionsprospekt oder einer prospektähnlichen Mitteilung massgeblich mitgewirkt haben (Passivlegitima-

Eine umfassende Analyse der Rechtslage würde den Rahmen dieses Aufsatzes sprengen. Deshalb werden nur die Ansprüche von Anleihensinhaber summarisch geprüft und es wird angenommen, dass es sich um einen rein binnenrechtlichen Sachverhalt handelt.

Vgl. anstatt vieler: BSK OR II-WATTER, Art. 752, N 2.

BGE 131 III 306, E. 2.1; BSK OR II-Watter, Art. 752, N 6; Forstmoser Peter/MeIer-Hayoz Arthur/Nobel Peter, Schweizerisches Aktienrecht, Bern 1996, § 37 N; Böckli Peter, Schweizer Aktienrecht, 4. A., Zürich 2009, §18 N 19; DObler SARAH/vON DER CRONE HANS CASPAR, Aktivlegitimation zur Geltendmachung von Verantwortlichkeitsansprüchen Entscheid des Schweizerischen Bundesgerichts 4C.111/2004 vom 9. November i.S. A. (Kläger und Berufungskläger) gegen X., Y. und Z. (Beklagte und Berufungsbeklagte), in SZW 4/ 2015, 211-217, 212 f.; FriTSCHI OlIVER, in: Fischer/Luterbacher (Hrsg.), Haftpflichtkommentar. Kommentar zu den schweizerischen Haftpflichtbestimmungen, Zürich/St. Gallen 2015, Art. 752 OR, N 33 ff.. 
tion). Mit "massgeblich“ ist dabei eine wesentliche Mitwirkung gemeint; entsprechend ist nicht jegliche Mitwirkung an einem Prospekt haftungsbegründend. In Frage kommen damit neben dem Emittenten und dessen Organe, Berater, Emissionsbanken oder Ratingagenturen. ${ }^{61}$

Widerrechtlichkeit bzw. Pflichtverletzung: Eine Widerrechtlichkeit bzw. Pflichtverletzung ist gegeben, wenn der Emissionsprospekt unrichtige oder irreführende Angaben enthält oder nicht den gesetzlichen Anforderungen entspricht. „Unrichtigkeit“ kann bejaht werden, wenn eine Angabe im Prospekt objektiv nicht den Tatsachen entspricht. Die fehlerhafte Information muss in einem direkten Zusammenhang mit der Emission stehen und insgesamt ins Gewicht fallen. ${ }^{62}$ In unserem Beispiel wäre die Angabe im Emissionsprospekt über die Verwendung des Erlöses unrichtig. Diese unrichtige Angabe steht in direktem Zusammenhang mit der Emission und fällt durchaus ins Gewicht, da es sich bei der Verwendung des Erlöses mitunter um das entscheidende Merkmal des Green Bonds handelt. Allerdings enthalten viele Prospekte Vorbehalte und Risikofaktoren bezüglich der Verwendung des Emissionserlöses und bezüglich der Erfüllung von ,grünen“ Kriterien.

Schaden: Der Schaden ergibt sich aus der Differenz zwischen dem gegenwärtigen Vermögensstand des betreffenden Investors und dessen hypothetischen Vermögensstand ohne Eintritt der Pflichtverletzung. Der Anleihensinhaber muss darlegen, dass er zum Zeitpunkt des Erwerbs einen geringeren Kaufpreis bezahlt hätte, falls die Angaben im Emissionsprospekt korrekt offengelegt worden wären bzw. alle relevanten Tatsachen erwähnt worden wären, wie beispielsweise die Tatsache, dass der Erlös nicht in grüne Projekte fliessen werden. Der Schadensbetrag ergibt sich somit aus der Differenz des tatsächlich bezahlten (höheren) Kaufpreises und des (tieferen) hypothetischen Kaufpreises. Eine grosse Hürde für den Investor besteht dementsprechend darin, den Nachweis für den Schaden zu erbringen (Substantiierungspflicht). ${ }^{63}$ Das wird in der Praxis regelmässig schwierig, wenn nicht unmöglich sein, denn das Preisschild für "grün“ dürfte sich nicht aus einer mathematischen Formel ableiten lassen.

61 BGE 132 III 715 E. 2; BSK OR II-WATTER, Art. 752, N 10 ff.; BÖCKLI, Schweizer Aktienrecht, §18 N 17 f.; FritsChi (Fn. 59), Art. 752 OR, N 37 ff.; Binder ANDREAS/Roberto Vito, in: Amstutz/ Breitschmid (Hrsg.), Handkommentar zum Schweizer Privatrecht, 752 OR, Rz 15.

62 BSK OR II-WATTER, Art. 752 N 13 ff.; BÖCKLI (Fn. 59), Schweizer Aktienrecht, §18 N 31; BINDER/ ROBERTO (Fn. 60), 752 OR, Rz 15; FrITSCHI (Fn. 59), Art. 752 OR, N 13 f.

63 BSK OR II-WATTER, Art. 752, N 22; BÖCKLI (Fn. 59), §18 N 34; CR CO II-CORBOZ/AuBRY GiRARDiN, art. 752, N 33 ff.; Binder/ROBERTO (Fn. 60), Rz 15; FritsChi (Fn. 59), Art 752 OR, N 27 ff. 
Kausalzusammenhang: Der Kausalzusammenhang hat bei der Prospekthaftung zwei Aspekte: Zum einen muss geprüft werden, ob der Prospektfehler überhaupt kausal für den Erwerb der Anleihe zu diesem Preis war, zum anderen bedarf es einer Kausalität zwischen Pflichtverletzung und Schaden ${ }^{64}$ Die Lehre verlangt für die erste Kausalität keine allzu hohen Anforderungen: Für diesen Fall kann angenommen werden, dass der betreffende Investor die Anleihe gekauft hat, weil sie eben gerade "grün“ sein sollte. Der zweite Aspekt, ob der Mangel auch tatsächlich einen Schaden im geltend gemachten Ausmass bewirkt hat, wobei insbesondere andere Faktoren, wie zum Beispiel die allgemeine Wirtschaftslage oder das Zinsniveau, bei der Schadensberechnung nicht miteinbezogen werden können, ist hingegen viel schwieriger darzulegen ${ }^{65}$ Im vorliegenden Beispiel muss eine Kausalität zwischen dem gesunkenen Aktienkurs und dem fehlenden "grünen“ Element hergestellt werden können. Dies dürfte in der Praxis regelmässig scheitern.

Verschulden: Nach Gesetzeswortlaut haften alle Beteiligten die absichtlich oder bereits fahrlässig bei der Offenlegung von unrichtigen Informationen oder der Unterlassung der Offenlegung wesentlicher Informationen im Prospekt mitgewirkt haben. Ob das Verschulden vermutet wird, ist in der Lehre strittig. Dabei wird ein objektivierter Verschuldensmassstab angewendet. Dem Gesetz sind keine besonderen Bestimmungen bezüglich der anzuwendenden Sorgfalt zu entnehmen. Somit müssen die Sorgfaltspflichten für alle Beteiligten im Einzelfall gesondert geprüft werden. ${ }^{66}$ Je nach Ursache, weshalb der Erlös nicht für die besagten grünen Projekte verwendet wurde, könnte ein Verschulden zu bejahen sein.

Aus dem Vorhergesagten ergibt sich, dass eine erfolgreiche Geltendmachung an Schaden und Kausalzusammenhang scheitern dürfte.

- Prospekthaftung unter FIDLEG:

Unter dem FIDLEG haftet eine Person einem Erwerber eines Finanzinstruments für jeglichen Schaden, der durch unrichtige oder irreführende Angaben im Prospekt, im Basisinformationsblatt oder in ähnlichen Mitteilungen verursacht wurde oder falls die gesetzlichen Anforderungen nicht eingehalten werden. ${ }^{67}$ Die Voraussetzungen von Ansprüchen der Prospekthaftung unter dem FIDLEG sind somit den Voraussetzungen der Prospekthaftung unter dem Obli-

64

BGE 132 III 715 E. 2.2; BSK OR II-WATTER, Art. 752, N 26.

APPENZELLER HANSJÜRG/WALLER STEFAN, Haftungsrisiken beim IPO und ihre Minimierung aus Sicht der Gesellschaft, in GesKR 3/2007, II 3.4; BSK OR II-WATTER, Art. 752, N 26 und 27a; BÖCKLI (Fn. 59), §18 N 36.

BSK OR II-WATTER, Art. 752 N 29 ff.; BÖCKLI (Fn. 59), §18 N 37.

Art. 69 Abs. 1 FIDLEG. 
gationenrecht in Bezug auf den vorliegenden Fall nachgebildet. Entsprechend kann für die Prüfung auf die Ausführungen zum OR verwiesen werden. Das FIDLEG sieht zusätzlich zwei Aufweichungen vor: (i) erstens wird die Haftung für Angaben in der Zusammenfassung eingeschränkt und zwar auf Fälle, in welchem sich die irreführenden, unrichtigen oder widersprüchlichen Angaben erst in Kombination mit anderen Teilen des Prospektes ergeben; (ii) zweitens ist keine Haftung für wesentliche Perspektiven (sog. forward looking statements) vorgesehen, sofern die Angaben nicht wider besseres Wissen oder ohne Hinweis auf die Ungewissheit zukünftiger Entwicklung gemacht oder verbreitet wurden. ${ }^{68}$

Das FIDLEG sieht zusätzlich zur zivilrechtlichen Haftungsbestimmung eine Strafbestimmung vor. Mit Busse bis zu CHF 500'000 wird bestraft, wer vorsätzlich falsche Angaben im Prospekt oder im Basisinformationsblatt macht, wesentliche Tatsachen verschweigt oder wer den Prospekt bzw. das Basisinformationsblatt nicht mit Beginn des öffentlichen Angebots veröffentlicht. ${ }^{69}$ In unserem Fall könnten alle Personen, die am Prospekt oder dem Basisinformationsblatt mitgewirkt haben, mit einer Busse von bis zu CHF 500'000 bestraft werden. In der Praxis dürfte dies allerdings eher unrealistisch sein, da Vorsatz gefordert ist, welcher regelmässig schwer beziehungsweise nur in ganz gravierenden Fällen nachzuweisen sein dürfte.

- Grundlagenirrtum:

Ein Grundlagenirrtum i.S.v. Art. 24 Abs. 1 Ziff. 4 OR ist ein qualifizierter Motivirrtum. Der Irrtum muss sich auf einen Sachverhalt beziehen, der im Zeitpunkt des Vertragsschlusses objektiv betrachtet als sicher angesehen werden konnte und die Gegenpartei nach Treu und Glauben im Geschäftsverkehr hätte erkennen müssen, dass dieser Sachverhalt Voraussetzung für den Vertragsschluss bildete. ${ }^{70}$ Prospekte von Green Bonds enthalten i.d.R. Warnhinweise, dass die Anleihe nicht in dem Masse "grün“ ist, wie der Erwerber sich das vorstellen könnte und dass bei Fehlen der notwendigen "grünen“ Kriterien keine Rückzahlung verlangt werden kann. Somit muss sich ein Käufer bewusst sein, dass die Anleihe zwar als "grün“ angepriesen wird, dieses aber nicht ein begriffsnotwendiges Element der Anleihe sein kann. Entsprechend schwer dürfte eine erfolgreiche Berufung auf einen Grundlagenirrtum sein.

Gegenüber einem externen Prüfer, welcher das Projekt zertifiziert hat, sowie der Ratingagentur:

\footnotetext{
68 Art. 69 Abs. 2 und 3 FIDLEG.

69 Art. 90 Abs. 1 FIDLEG.

70 BSK OR I-FOUNTOULAKIS Art. 24, N 17 f. m.w.H.
} 
- Vertragliche Ansprüche:

Zwischen den externen Prüfer bzw. Ratingagentur und dem Investor eines Green Bonds besteht kein Vertrag. Somit kann sich eine Haftung nicht aus einem vertraglichen Verhältnis ergeben.

- Quasi-vertragliche Ansprüche: Vertrauenshaftung:

Zwischen Anleihensinhaber und dem externen Prüfer bzw. Ratingagentur muss eine rechtliche Sonderverbindung bestehen. Diese setzt ein vertrauenserweckendes Verhalten seitens des externen Prüfers bzw. der Ratingagentur voraus, welches beim Investor ein berechtigtes Vertrauen hervorruft. Der externe Prüfer muss in der Folge das berechtigte Vertrauen des Erwerbers in treuwidriger Weise enttäuschen. ${ }^{71}$ Eine rechtliche Sonderverbindung kann dann bejaht werden, wenn ein bestimmtes Verhalten einen Vertrauenstatbestand begründen kann. Bereitet eine Person Informationen mit dem Zweck so auf, dass sie dem Empfänger aufwendige Nachforschungen erspart, nimmt die betreffende Person einen Einfluss auf den Empfänger, dessen erwecktes Vertrauen grundsätzlich als schützenswert gilt. Die Lehre setzt aber voraus, dass es eine bestimmte "Gerichtetheit" der Information geben muss und der Personenkreis objektiv begrenzt ist. Letzterer ist bei Ratingagenturen zwar sehr weit (alle Markteilnehmer des Kapitalmarkts), wird gemäss Lehre aber von den Ratingagenturen in Kauf genommen, weil diese ihre Ratings veröffentlichen. ${ }^{72}$ Dasselbe muss für einen externen Prüfer gelten, welcher zertifiziert, dass eine Anleihe, bestimmten Kriterien, wie denjenigen des Climate Bonds Standard, entspricht. VASELLA unterscheidet für Ratingagenturen zwischen Emissionsrating und Emittentenrating. Während beim ersten die Ratingagentur die Ratingagentur die Haftungsfolgen aufgrund des Emissionsvolumen abschätzen kann, sieht er die Drittbezogenheit als gegeben an, während er bei einem Emittentenrating diese verneint, weil dieses nicht auf eine bestimmte Emission hin erfolgt ist. ${ }^{73}$ Diese Interpretation wäre u.E. zu hinterfragen, denn ein Emittentenrating lässt durchaus Rückschlüsse auf die allgemeine Bonität und damit das Ausfallrisiko im Rahmen einer Emission zu, ist hier aber ohne Belang, da es sich vorliegend um ein Emissionsrating handelt.

Zum Schaden kann auf die Ausführungen unter der Prospekthaftung verwiesen werden. Bei der Kausalität stellt sich wie auch bei der Prospekthaftung

71 Huguenin ClaiRe, Obligationenrecht - Allgemeiner und Besonderer Teil, Zürich 2019, $\mathrm{N} 1738 \mathrm{ff}$.

72 Vgl. Frick JÜRG/JOST HANNA, Haftung von Ratingagenturen, in: Reutter/Werlen (Hrsg.), Kapitalmarkttransaktionen XI, Zürich 2017, 131-194, 178 f. und VASELLA DAVID, Die Haftung von Ratingagenturen, Zürich 2011, Rz 817 ff.

73 VASELLA (Fn. 71), $849 \mathrm{ff}$. 
die Schwierigkeit, dass das fehlende „grüne“ Element kausal für einen tieferen Marktpreis war, schwierig nachzuweisen sein dürfte. Ob im vorliegenden Fall das Verschulden des externen Prüfers gegeben ist, kann nicht abschliessend beurteilt werden. Hat der Emittent vor der Emission glaubhaft darlegen können, dass der Erlös dem Climate Bonds Standard entsprechend eingesetzt wird, so könnte der Exkulpationsbeweis des externen Prüfers gelingen, wenn er nachweisen kann, dass er die notwendige Sorgfaltspflicht eingehalten hat. Die Ratingagentur dürfte sich noch überzeugender auf das fehlende Verschulden als der externe Prüfer berufen können: Vermutlich kann sie darlegen, dass sie insbesondere aufgrund des Zertifikats annehmen durfte, dass die Anleihe dem Climate Bonds Standard entspricht, weshalb ihr kein Verschulden zu Last gelegt werden könne.

Haben der externe Prüfer und die Ratingagentur Enthaftungs- und Freizeichnungsklauseln angefügt, stellt sich die Frage nach deren Wirkung. Während bei der Enthaftungsklausel ein Teil der Lehre eine solche nur für absichtliche oder grobe Verfahrensfehler ausschliessen möchte, gibt es Lehrmeinungen, welche auch leichte Fahrlässigkeit als ausgeschlossen haben möchte. ${ }^{74} \mathrm{Je}$ nachdem, ob es für den externen Prüfer und die Ratingagentur bei der Anwendung gehöriger Sorgfalt erkennbar war, ob der Erlös nicht so verwendet werden würde, wie der Emittent beschrieben hat, könnte eine Enthaftungsklausel greifen oder nicht. Weil nicht davon ausgegangen werden kann, dass Freizeichnungsklauseln von Investoren gutgeheissen und angenommen worden sind, greifen solche gemäss Lehre im Kontext der Vertrauenshaftung nicht. ${ }^{75}$ Entsprechend könnte sich keiner der beiden darauf berufen.

- Ausservertragliche Ansprüche:

Als klassische ausservertragliche Haftungsnorm kommt Art. 41 OR in Frage. Art. 41 OR verlangt (i) einen Schaden, (ii) einen natürlichen und adäquaten Kausalzusammenhang zwischen dem schädigenden Verhalten und dem Schaden, (iii) die Widerrechtlichkeit der Schädigung sowie (iv) ein Verschulden des Schädigers. ${ }^{76} \mathrm{Zu}$ den verschiedenen Problemfeldern bei Schaden, Kausalzusammenhang und Verschulden kann nach oben verwiesen werden, weshalb an dieser Stelle lediglich auf die Widerrechtlichkeit eingegangen werden soll. Gemäss herrschender Lehre und bundesgerichtlicher Rechtsprechung ist für die Widerrechtlichkeit die sogenannte objektive Widerrechtlichkeitstheorie anwendbar, wonach ein Schaden nur dann widerrechtlich ist, wenn sie gegen eine allgemeine gesetzliche Pflicht verstösst. Ein Verstoss gegen eine allge-

\footnotetext{
74 Vgl. für eine Übersicht FrICK/Jost (Fn. 71), 182 f.

$75 \quad$ FRICK/JOST (Fn. 71), $182 \mathrm{f}$.

76 BSK OR I- KESSLER, Art. 41 N 2c.
} 
meine gesetzliche Pflicht liegt vor, wenn entweder ein absolutes Recht des Schädigers verletzt worden ist oder eine reine Vermögensschädigung durch Verstoss gegen eine Schutznorm (Verhaltensunrecht) eingetreten ist, ohne dass ein Rechtfertigungsgrund vorliegt. ${ }^{77}$ Da vorliegend ein reiner Vermögensschaden eingetreten ist, muss der externe Prüfer bzw. die Ratingagentur eine Schutznorm verletzt haben. Green Bonds Standards, Frameworks von Green Bonds oder interne Richtlinien von externen Prüfern oder Ratingagenturen haben keinen Charakter einer Vermögensschutznorm, weil diese nicht zum Zweck des Schutzes von Vermögensschäden von Investoren aufgestellt wurden. Entsprechend können der externe Prüfer und die Ratingagentur in dieser Konstellation nicht aus Art. 41 OR belangt werden.

Zusammenfassend kann festgehalten werden, dass faktisch keine rechtlichen Durchsetzungsmöglichkeiten für Investoren vorhanden sind, welche bei einer Nichteinhaltung von Kriterien für einen Green Bond erfolgreich geltend gemacht werden könnten. Entsprechend werden in der Praxis auch Stimmen laut, welche einen green default oder andere Mechanismen fordern, um ein Greenwashing zu verhindern und die Glaubwürdigkeit von Green Bonds zu stärken. ${ }^{78}$

\section{h) Herausforderungen}

Verschiedene nichtstaatliche Regierungsorganisationen sowie Regierungen möchten Green Bonds zum Aufschwung verhelfen. Obwohl die Anzahl und das Volumen der Green Bonds in den letzten Jahren stark angestiegen sind, machen Green Bonds nach wie vor nur einen kleinen Teil der ausgegebenen Anleihen aus. Weshalb ist dem so?

Vermutlich spielen verschiedene Faktoren eine Rolle, welche dazu führen, dass Green Bonds nicht verbreiteter sind. Die EU identifizierte folgende Herausforderungen, die u.E. zutreffend sind: ${ }^{79}$

Ein Emittent muss über ein oder mehrere Projekte verfügen, welche sich für eine Finanzierung mittels einer Anleihe eignen. Ist ein Projekt nicht bankenfähig oder benötigt es keine Refinanzierung, so kommt es für eine Anleihe nicht in Betracht. Dabei ist oftmals auch die Grösse von Projekten, welche potentiell mittels Anleihe finanziert werden sollen, eine Herausforderung: Ein Projekt alleine ist oftmals zu klein für eine Anleihe, so dass der Emittent verschiedene Projekte aggregieren muss. Diese haben regelmässig aber zu unterschiedli-

BSK OR I- KESSLER, Art. 41 N 31.

Vgl. Fn. 56.

79 EU Green Bond Framework, 24.
} 
chen Zeitpunkten einen Finanzierungsbedarf, so dass diese sich nicht leicht in einem Gefäss zusammenführen lassen. Des Weiteren fehlen oftmals anerkannte Standards, um potentielle Projekte zu identifizieren, was einen Mehraufwand auf der Emittentenseite verursacht. Zu guter Letzt haben Emittenten häufig Schwierigkeiten, ein gutes Rating zu erhalten, weil grüne Investitionen auf Investorenseite allgemein als risikoreicher gelten.

Es sind aber nicht nur die Emittenten, welche vor Herausforderungen stehen. Auch auf Investorenseite sind Bedenken vorhanden, welche ein Wachstum bremsen. Weil die Offenlegungspflichten nicht festgelegt sind, fehlen teilweise Informationen über die Auswirkungen von Green Bonds Projekten, was Investoren eine umfassende Einschätzung über das zu finanzierende Projekt erschwert. Aufgrund von fehlenden Standards und Definitionen, was unter einem Green Bond zu verstehen ist, müssen Investoren Zeit und Geld aufwenden, um herauszufinden, ob eine Anleihe, welche als Green Bond verkauft wird, auch tatsächlich ein Green Bond im Verständnis des betreffenden Investors ist. Second Opinions, welche über einen Green Bond Aufschluss geben sollten, sind zum Teil ungenügend in der Qualität, so dass sie ihren eigentlichen Zweck nicht erfüllen. Und wie schon angesprochen gelten Green Bonds als risikoreicher als „normale“ Anleihen, weshalb sich viele Investoren von dieser Anlageklasse abschrecken lassen.

\section{Weitere Anlageklassen}

Neben Green Bonds existieren auch andere grüne Anlageklassen. Auf der Fremdkapitalseite sind dabei an green loans oder green funds zu denken, welche aber weitaus weniger bekannt und häufig vorkommen als Green Bonds. Im Kern folgen solche Emissionen demselben Muster wie die vorgestellten Green Bonds: Sie sind rechtlich nach wie vor dasselbe Instrument, aber eben mit der Besonderheit, dass sie ein grünes Projekt finanzieren oder refinanzieren.

Nicht alle Anlageklassen sind gleich geeignet für ein Green-Labelling: Die Fremdkapitalseite eignet sich besonders gut, weil dabei ein bestimmtes Projekt finanziert werden kann. Handelt es sich hingegen um Aktien oder andere eigenkapitalähnliche Anteile, so geht ein Green-Labelling nur, wenn die gesamte Tätigkeit des betreffenden Emittenten nachhaltig ist, wie zum Beispiel bei einem Solarpanelhersteller.

Es wäre sicherlich wünschenswert, wenn andere Anlageklassen, wie zum Beispiel green loans mehr in den Fokus rücken würden, damit ein breiteres Spektrum von potentiell nachhaltigen Investitionen abgedeckt werden kann. 


\section{Regulierungsbedarf und -ansätze}

Die vorherigen Abschnitte waren primär dem Status quo gewidmet. In diesem Abschnitt möchten wir einen Ausblick wagen, indem wir uns fragen, welche Massnahmen ergriffen werden sollten, um Green Bonds oder andere nachhaltige Investments attraktiver zu machen.

- Kein anerkanntes Begriffsverständnis von „grünen“ Emissionen

Was grüne Emissionen kostspielig macht, ist das Fehlen von anerkannten Standards, welche grüne Emissionen genügend konkret regeln. Es fehlt bereits an einem breit anerkannten Verständnis was unter "grün“ zu verstehen ist. Dabei stellen sich zahlreiche Fragen: Zum Beispiel, an welchem Standard das betreffende Projekt zu messen ist. Genügt ein geringerer CO2-Ausstoss, welcher das Pariser Klimaübereinkommen einhält, oder muss auf andere bzw. höhere Standards abgestellt werden? Ebenso zu klären wäre, ob es auf den Endzweck des betreffenden Projekts ankommt. Kann beispielsweise eine solarbetriebene Tankstelle als grünes Projekt angesehen werden? Dafür spricht, dass es sich um eine Anlage handelt, welche in Zukunft keine (oder nur sehr geringe) Emissionen ausstossen wird. Dagegen kann man natürlich halten, dass die Tankstelle für das Tanken von Autos gebaut wird, was an sich klar nicht nachhaltig ist.

Anerkannte Standards wären demnach u.E. dringend nötig. Zwar ragen die ICMA Principles und die Climate Bonds Initiative unter den unzähligen Standards heraus, doch existieren nach wie vor unzählige Standards und Labels, welche dem Investor zusätzliche Recherchearbeiten aufbürden, wenn er herausfinden möchte, welche Anforderungen ein jeweiliger „Green Bond“ erfüllt.

- Hard vs. Soft Law

Als erstes stellt sich die Frage, in welcher Form solche Standards erlassen werden sollten bzw. ob solche Standards in Form von Gesetzen (sog. hard law) oder unverbindlichen Standards (sog. soft law) erlassen werden sollten. Der Vorteil von Gesetzen ist die Verbindlichkeit, welche Klarheit schafft und verschiedene Interpretationen grundsätzlich abschafft. ${ }^{80}$ Nachteilig wirkt sich aus, dass Gesetze in der Regel eine gewisse Starrheit aufweisen, dass sich insbesondere bei rasch ändernden Gegebenheiten als Nachteil erweisen kann. Abgefedert werden kann dieser Nachteil, indem Einzelheiten dem Verordnungsgeber delegiert wird, welcher rascher auf veränderte Bedürfnisse reagieren kann. Ein andere Gefahr bei Gesetzen besteht darin, dass jeder Staat eine eigene Regelung erlässt, welche nicht kompatibel mit denjenigen eines

Voraussetzung dazu ist natürlich der Erlass eines Gesetzes, das genügend klar und verständlich ist, und keine zentralen Fragen in der Interpretation aufwirft. 
oder mehreren anderen Staaten ist, was sowohl international tätige Gesellschaften oder Konzerne als auch Investoren vor Herausforderungen stellt, weil sich die verschiedenen Regeln nicht einfach vergleichen lassen. Entsprechend wäre es wünschenswert, dass auf internationaler Ebene ein Konsens gefunden werden würde. Umgesetzt hat dies bereits die EU, welche mit Ihrer Verordnung bereits ein Regelwerk geschaffen hat. Damit nimmt die EU eine Vorreiterrolle ein.

Folgt man dem anderen Ansatz und sollen nur unverbindliche Standards herausgegeben werden, bestünde eine andere Möglichkeit darin, dass eine internationale Organisation ein Regelwerk schafft, welches dann einheitlich freiwillig angewendet werden könnte. Zu denken wäre etwa an einen GRI für nachhaltige Emissionen, welcher von einer UN-Organisation geschaffen wurde. Allerdings zeigt sich gerade am Beispiel von Nachhaltigkeitscodes, dass mangels staatlichen Regeln ein Wildwuchs an verschiedenen Prinzipien und Guidelines entstanden sind, welche sowohl bei Emittenten als auch Investoren keine wirkliche Abhilfe geschaffen haben bzw. das Problem verlagert haben.

Eine weitere Frage stellt sich hinsichtlich der Regeldichte. Während die ICMA Principles (wie auch andere Regelwerke) relativ vage sind, hatte die EU in ihrer Taxonomie eine ganz andere Herangehensweise gewählt, indem sie über mehrere hundert Seiten für verschiedene Industrien genaue Zahlenwerte festgehalten hat. Der Vorteil von Prinzipien, welche lediglich in allgemeiner Form Vorgaben enthalten, ist offensichtlich: Sie sollen für möglichst viele Emissionen anwendbar sein und sollen die Grundidee widergeben. Die Gefahr dabei ist aber, dass sie so vage sind, dass sie wiederum Fragen bei der Umsetzung aufwerfen und sie sich auch auf nicht nachhaltige Emissionen anwenden lassen, weil sie (zu) viel Umsetzungsspielraum lassen. Folgt man dem Konzept der EU, so scheinen sich zwar viele Probleme gelöst zu haben, doch wird der Leser mit einer Menge von spezifischen Vorgaben konfrontiert, welche dieser wiederum in einem längeren Studium sich zu Gemüte führen muss. Diesen Aufwand werden vermutlich die meisten Investoren scheuen und es ist auch zu befürchten, dass eine solche Regelungsdichte Emittenten abschrecken wird. U.E. wäre ein Regelwerk, das zwar nicht so vage wie die heutigen ICMA Principles ist, aber dennoch nicht mit einer so hohen Regelungsdichte wie es die EU vorgemacht hat, vermutlich die bessere Lösung. U.E. ist es ratsamer, Standards zu setzen, als jede einzelne Art von potentiell grüner Emission regeln zu wollen. Wir denken dabei an ein Regelwerk, das Prinzipien vorgibt, die konkretisieren, was unter "grün“ zu verstehen ist.

- Viele unterschiedliche Standards

Standards oder Prinzipien für grüne Emissionen gibt es viele. Entsprechend ist es für Investoren aufwendig, sich mit verschiedenen Standards auseinander- 
setzen zu müssen, was sich für die wenigsten Investoren auszahlt. Aber auch Emittenten haben einen zusätzlichen Aufwand, weil sie sich zuerst entscheiden müssen, welchem Standard sie folgen möchten. Die EU versucht dem entgegenzuwirken, indem sie ein EU Green Bond Framework lanciert, das auch auf die EU Taxonomie Bezug nimmt. Grundsätzlich ist ein so umfassendes Regelwerk begrüssenswert, doch ist die Taxonomie u.E. nicht benutzerfreundlich ausgestaltet. Für die Schweiz wird sich die schwierige Frage stellen, ob sie der EU folgen wird, was der Vorteil in sich birgt, dass das Regelwerk vielen Investoren bekannt sein dürfte. Ob die Taxonomie allerdings wirklich so benutzerfreundlich ist, dass sie Nachahmung verdient, wird noch abzuwarten sein.

- Grüne Emissionen sind schwierig zu finden

Zwar emittieren erfreulicherweise immer mehr Gesellschaften grüne Anleihen, doch wird es dem Investor nicht immer einfach gemacht, diese zu finden. Obwohl verschiedene Datenbanken existieren (Liste auf der SIX-Webseite oder der Climate Bonds Initiative), sind diese i.d.R. an ein oder mehrere Regelwerke geknüpft, die aufgrund der starken Fragmentierung der Standards wiederum nicht vollständig sind.

- Fehlender monetärer Vorteil

Zwar ist sowohl auf der Emittenten- als auch auf der Investorenseite angekommen, dass nachhaltige Emissionen den Nerv der Zeit berühren. Wenn es jedoch um die konkrete Umsetzung geht, so kann sich zeigen, ob die Kosten den potentiellen Vorteil übersteigen. Ein Vorteil könnte neben der Reputation auch eine breitere Investorenbasis sein. Solche Kriterien lassen sich aber nicht messen. Aber auch auf der Investorenseite fallen Kosten an, denn diese müssen prüfen, ob das zu finanzierende Projekt auch tatsächlich „grün“ ist, so wie das ihrem Verständnis entspricht. Um dem entgegenzuwirken gab es bereits Vorstösse im Parlament, welche Anreize, wie zum Beispiel Steuererleichterungen, für nachhaltige Investitionen schaffen möchte.$^{81}$ Labelling wäre ebenfalls eine Möglichkeit, grüne Emissionen stärker hervorzuheben.

- Fehlende Rechtsverbindlichkeit und Gefahr von Greenwashing

Regelmässig sehen Bedingungen von emittierenden grünen Finanzinstrumenten keine Konsequenz vor, wenn die vorgestellten grünen Kriterien zu einem späteren Zeitpunkt wegfallen. Mögliche Konsequenzen wären insbesondere die vorzeitige Rückzahlung oder die Bezahlung einer Prämie. Fehlen solche Mechanismen, so kommt rasch der Verdacht auf, dass sich der Emittent „billig“ ein gutes Image verschaffen möchte, indem er im Rahmen der Emission ein 
grünes Projekt vorstellt, von dem er weiss, dass die Umsetzung unabhängig von der Finanzierung auch „braun“ werden kann (sog. Greenwashing). Damit sinkt nicht nur die Glaubwürdigkeit, dass es solche Emittenten auch wirklich ernst meinen, sondern auch die Bereitschaft von Investoren, sich mit einem Projekt zu beschäftigen und zu investieren. Ein guter Ansatz wählen u.E. die Sustainability-Linked Bond Principles der ICMA, welche vordefinierte messbare Kennzahlen fordern, die von einem Emittenten im Rahmen der Ausgabe eines Finanzinstrumentes erreicht werden müssen. Von den Emittenten ist zu fordern, dass bei Nichterreichen von den gesetzten Zielen eine Art von „Sanktion" folgt, welche in den Anleihensbedingungen festgehalten ist, wie zum Beispiel die Erhöhung des Zinssatzes.

- Auswirkungen von COVID-19

Zum Zeitpunkt des Drucks dieses Artikels ist noch nicht absehbar, ob, und wenn ja, welche Folgen der Coronavirus auf Green Bonds hat. Bis anhin hat die Krise den Green Bonds einen Aufschwung verliehen. U.E. ist es allerdings durchaus möglich, dass Investoren aufgrund der Krise vermehrt auf Liquidität achten und damit nachhaltige Kriterien wieder in den Hintergrund rücken. Das könnte Green Bonds und CSR allgemein den bisherigen Schwung nehmen, was sehr bedauerlich wäre.

\section{Fazit}

Zusammenfassend kann festgehalten werden, dass CSR immer mehr an Bedeutung gewinnt; diese Bewegung macht auch vor dem Kapitalmarkt nicht Halt. Als beliebteste (und auch sehr geeignete) Form einer nachhaltigen Anlegerklasse fungieren Anleihen, welche am häufigsten in Form von Green Bonds vorkommen.

Bis anhin waren nachhaltige Emissionen weitestgehend unreguliert. Als Folge davon entstanden unzählige unverbindliche Richtlinien von privaten Akteuren, welche neue Standards setzen wollten. Das hat es wiederum sowohl für Emittenten als auch Investoren schwer gemacht, sich zurecht zu finden. Als Folge davon und wohl auch aufgrund von Greenwashing-Vorwürfen werden Forderungen laut, dass Gesetzgeber verbindliche Regelungen schaffen sollten. Vorreiterrolle hat die EU eingenommen, die bereits eine Taxonomie und ein EU Green Bond Framework entwickelt. Die Massnahmen des Bundesrates setzen nach wie vor auf Freiwilligkeit. Wie lange das so bleiben wird, ist aufgrund der Entwicklungen in der EU fraglich. Möchte die Schweiz fortschrittlich dastehen, so wird sie früher oder später ebenfalls ein verbindliches Regelwerk schaffen müssen. Dabei stellt sich für sie die Frage, ob sie der EU folgen oder ihren eigenen Weg gehen möchte. Vorbehaltlos können wir das Regel- 
werk aufgrund der enormen Dichte nicht empfehlen, doch könnte dieses aufgrund deren Verbreitung bei Investoren dasjenige sein, das schlussendlich am bekanntesten ist.

Trotz des Vorhergesagten machen nachhaltige Anleihen nach wie vor einen kleinen Anteil des Gesamtvolumen der Emissionen aus und dies dürfte auch in den nächsten Jahren noch so bleiben. Zahlreiche Hürden hemmen nämlich das Wachstum. Insbesondere dürften die zusätzlichen Kosten im Zusammenhang mit der Ausgabe eines nachhaltigen Instruments sowohl auf der Emittenten- wie auch Investorenseite dazu führen, dass konventionelle Emissionen nach wie vor die primäre Option ist. Entsprechend wird die zukünftige gesetzgeberische Ausgestaltung von nachhaltigen Finanzinstrumenten eine wichtige Rolle spielen.

Aktuell sind viele Fragen bezüglich CSR im Kapitalmarkt ungeklärt. Weil es bei CSR um "gutes Geschäftsgebaren“ geht, sind diese Fragen nicht leicht zu beantworten bzw. sind oftmals verschiedene Lösungen denkbar. Was allerdings schon klar ist: Wir dürfen in den nächsten Jahren mit grossen Veränderungen rechnen. Somit wird dieses Thema auch zukünftig nicht an Spannung verlieren. 


\title{
DLT-Vorlage des Bundesrates: Zivil- und finanzmarktrechtliche Aspekte
}

\author{
Sonja Maire/Arie Gerszt**
}

\section{Inhalt}

I. Einleitung ……………………………………………………………………………...122

II. Bericht des Bundesrates zu den rechtlichen Grundlagen für Distributed Ledger-Technologie und Blockchain in der Schweiz vom Dezember 2018

1. Zielsetzungen und Grundsätze des Schweizer Regulierungsansatzes für Blockchain und Distributed Ledger-Technologie.

2. Erkenntnisse ………………………………………………………………...125

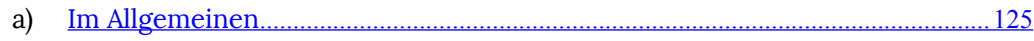

b) Im Besonderen: Im Zivilrecht............................................................................125

aa) Schriftformerfordernis bei der Übertragung von Rechten

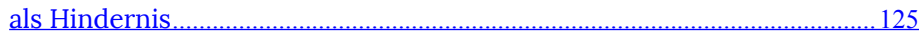

bb) Kein Handlungsbedarf bei der Übertragung von Kryptowährungen .......127

cc) Kein Handeln angezeigt bei der Abbildung und Übertragung von dinglichen Rechten .............................................................................. 128

c) Im Besonderen: Im Insolvenzrecht ...............................................................131

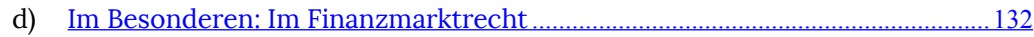

III. Die DLT-Vorlage des Bundesrates vom November 2019 ………………………………....132

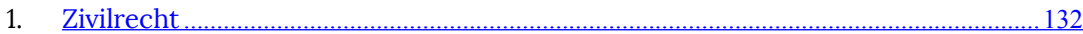

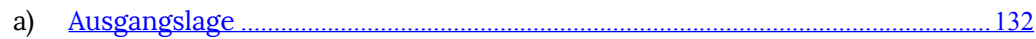

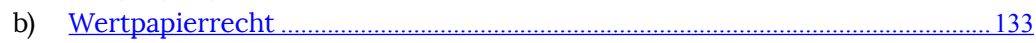

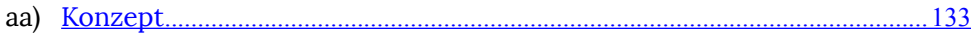

bb) Anforderungen an Register und Adressierung von Risiken ........................133

cc) Wirkungen der Ausgestaltung als Registerwertrecht...................................137

dd) Ausblick: Prüfung einer weiteren Öffnung bei der Übertragung

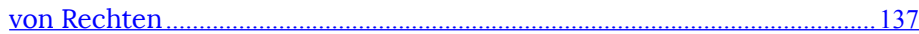

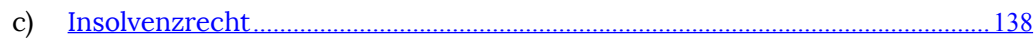

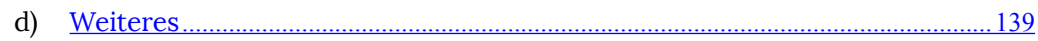

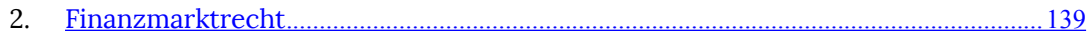

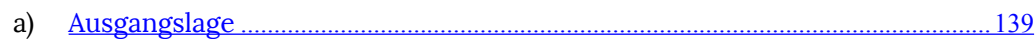

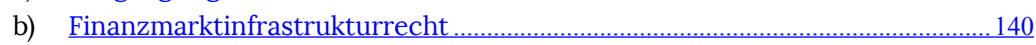

aa) DLT-Handelssystem....................................................................................140

bb) „Sandbox“ im Finanzmarktinfrastrukturrecht? .............................................143

* Die Autoren vertreten hier ausschliesslich ihre eigene Meinung und binden das Bundesamt für Justiz sowie das Staatssekretariat für internationale Finanzfragen nicht. 


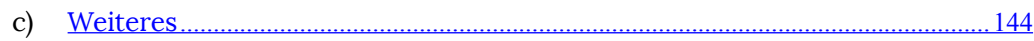

d) Regelung vollständig dezentraler „Infrastrukturen“? ?............................................146

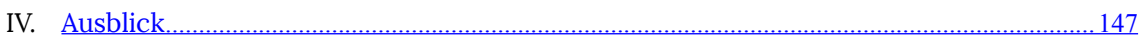

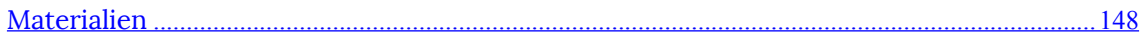

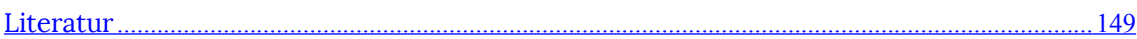

\section{Einleitung}

Nachdem die Blockchain-Technologie der Öffentlichkeit zunächst meist nur im Zusammenhang mit dem Bitcoin ein Begriff war, entstand in der Schweiz vor einigen Jahren eine Branche, welche vom Nutzen der zugrundeliegenden Technologie überzeugt war und entsprechende Anwendungen zu entwickeln begann. Zur Finanzierung dieser Projekte wurde schon bald das breitere, technologiebegeisterte Publikum aufgerufen, welches für seine Beiträge sogenannte Token oder Coins erhielt, welche oft mit einem Versprechen auf eine zukünftige Gegenleistung (z.B. Gewinnbeteiligung, Zugang zu Speicherplatz etc.) verbunden waren. Im Jahr 2017 verzeichnete die Schweiz eine wahre Welle von solchen Initial Coin Offerings (ICO), viele davon mit Bezug zum Grossraum Zug und zum sogenannten Cryptovalley. Auch traditionelle Firmen begannen sich zunehmend mit der neuen Technologie zu beschäftigen. Leider zog die anfängliche Begeisterung - sowohl in der Schweiz als auch im Ausland - teilweise jedoch auch Betrüger an und führte auch zu einigen unseriösen Angeboten.

Als Aufsichtsbehörde im Finanzmarkt war die Eidgenössische Finanzmarktaufsicht FINMA früh aufgerufen, sich zu positionieren. Am 29. September 2017 publizierte sie die Aufsichtsmitteilung 04/2017 zur aufsichtsrechtlichen Behandlung von Initial Coin Offerings ${ }^{1}$. Im Februar 2018 folgte eine Wegleitung für Unterstellungsanfragen betreffend ICOs, mit der eine erste offizielle finanzmarktrechtliche - Qualifikation von Token vorgenommen wurde. ${ }^{2}$

Der Bundesrat äusserte sich bereits 2014 ein erstes Mal zum Bitcoin-Phänomen in seinem Bericht zu virtuellen Währungen in Beantwortung der Postulate Schwaab (13.3687) und Weibel (13.4070). ${ }^{3}$ Aufgrund der rasanten Entwick-

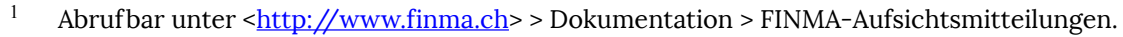

2 Vgl. Eidgenössische Finanzmarktaufsicht FINMA, Wegleitung für Unterstellungsanfragen betreffend Initial Coin Offerings (ICOs), Ausgabe vom 16. Februar 2018. Kann abgerufen werden unter $<$ www.finma.ch $>>$ Bewilligung $>$ Fintech.

3 Abrufbar unter $<$ http://www.parlament.ch $>>$ Ratsbetrieb $>$ Suche Curia Vista $>$ GeschäftsNr. 13.3687.
} 
lungen im Bereich der Initial Coin Offerings (ICOs) erklärte der Bundesrat in seiner Stellungnahme vom 15. November 2017 zur Motion Béglé 17.3818 „Die Schweiz zu einem Weltzentrum der Blockchain-Technologie machen“, dass das Staatssekretariat für Internationale Finanzfragen (SIF) eine Arbeitsgruppe mit Einbezug der betroffenen Ämter und der Branche einsetzen werde, um die notwendigen Abklärungen in Bezug auf die Blockchain-Technologie vorzunehmen und einen allfälligen Handlungsbedarf aufzuzeigen.

Am 18. Januar 2018 setzte das SIF die Arbeitsgruppe Blockchain/ICO ein. Diese umfasste eine Steuerungsgruppe bestehend aus den jeweiligen Amtsspitzen des SIF, des Bundesamtes für Justiz (BJ) und der FINMA und mit Einsitz der Eidgenössischen Steuerverwaltung (ESTV), sowie zwei Untergruppen - geleitet vom SIF einer- und vom BJ andererseits - mit zusätzlichen Vertreterinnen und Vertretern der FINMA, der Nationalbank (SNB), des Bundesamtes für Polizei (fedpol), der Eidgenössischen Zollverwaltung (EZV) und des Staatssekretariats für Wirtschaft (SECO). Mit der Branche fanden mehrere Treffen statt, auch wurden weite Kreise im Herbst 2018 zu einer schriftlichen Vorkonsultation eingeladen, in welcher die Arbeitsgruppe erste Überlegungen präsentierte. Am 14. Dezember 2018 veröffentlichte der Bundesrat den Bericht „Rechtliche Grundlagen für Distributed Ledger-Technologie und Blockchain in der Schweiz" (nachfolgend: DLT-Bericht). ${ }^{4}$ Die Arbeiten der Arbeitsgruppe fanden mit dem Gesetzesentwurf und der Botschaft des Bundesrates vom 27. November 2019 über das Bundesgesetz zur Anpassung des Bundesrechts an Entwicklungen der Technik verteilter elektronischer Register ${ }^{5}$ (nachfolgend: DLT-Vorlage) ihren vorläufigen Abschluss.

\section{Bericht des Bundesrates zu den rechtlichen Grundlagen für Distributed Ledger-Technologie und Blockchain in der Schweiz vom Dezember 2018}

I. Zielsetzungen und Grundsätze des Schweizer Regulierungsansatzes für Blockchain und Distributed Ledger-Technologie

Die Distributed Ledger Technologie (DLT) zählt zu den bemerkenswerten und vielversprechenden Entwicklungen im Kontext der Digitalisierung. Der Entwicklung dieser Technologien wird dabei sowohl im Finanzsektor als auch in anderen Wirtschaftssektoren ein erhebliches, wenn auch nicht abschliessend

\footnotetext{
4 Abrufbar unter $<$ https://www.admin.ch/gov/de/start/dokumentation/medienmitteilungen.msg-id-73398 .html>.

5 BBl 2020, $233 \mathrm{ff}$.
} 
abschätzbares Innovations- und Effizienzsteigerungspotenzial vorausgesagt. ${ }^{6}$ Der Bundesrat will dabei die Voraussetzungen weiter verbessern, damit die Schweiz die Chancen dieser Technologien nutzen kann.

Vor diesem Hintergrund verabschiedete der Bundesrat im Dezember 2018 seinen Bericht zu den rechtlichen Rahmenbedingungen für Blockchain und Distributed-Ledger-Technologie (DLT) im Finanzsektor. Der Bericht setzt sich mit den Technologien auseinander und beinhaltet auch die Zielsetzungen und Grundsätze des Schweizer Regulierungsansatzes für DLT und Blockchain. ${ }^{7}$ Der Bundesrat legt dem DLT-Bericht dabei folgende Grundsätze zugrunde: ${ }^{8}$

- Bottom-up Ansatz: Die Präferenzen des Markts und der Gesellschaft sollen darüber entscheiden, welche Technologien sich durchsetzen, während die Politik für optimale, innovationsfreundliche Rahmenbedingungen sorgen soll.

- Gezielte Anpassungen: Die Schweiz soll ihren bewährten und ausgewogenen Rechtsrahmen nicht grundsätzlich in Frage stellen, aber bei Bedarf rasch gezielte Anpassungen vornehmen, wo es im Hinblick auf DLT-/BlockchainAnwendungen Lücken oder Hindernisse gibt.

- Grundsätzlich technologieneutraler Ansatz: Die Schweiz soll weiterhin einen prinzipienbasierten und technologieneutralen Rechtsetzungs- und Regulierungsansatz verfolgen, jedoch bei Bedarf auch Ausnahmen zulassen; dabei sind die Regeln möglichst wettbewerbsneutral zu gestalten.

- Rechtssicherheit, klare Regeln und Missbrauchsbekämpfung: Die Schweiz soll sich gegenüber DLT-/Blockchain-Unternehmen mittels Rechtssicherheit, effizienter Regulierung und guter Reputation als attraktiver Standort positionieren; dabei wird die Nutzung innovativer Technologien für betrügerisches oder missbräuchliches Verhalten oder zur Umgehung des regulatorischen Rahmens nicht toleriert.

- Offenheit und Dialog: Die Schweizer Behörden sollen sich gegenüber neuen Technologien und Innovationen wie Blockchain und DLT offen positionieren und einen regelmässigen Dialog mit der Branche pflegen.

Zusammenfassend lässt sich festhalten, dass der Bundesrat in Bezug auf DLT und Blockchain bestmögliche Rahmenbedingungen schaffen will, damit sich die Schweiz als Standort für Fintech- und Blockchain-Unternehmen etablieren

\footnotetext{
$6 \quad$ Vgl. BBl 2020, 233, 238.

7 Vgl. DLT-Bericht, 13 ff. Zur Entstehung des DLT-Berichts, vgl. BBl 2020, 239 sowie DLTBericht, $15 \mathrm{f}$.

$8 \quad$ Vgl. BBl 2020, 239 f.; DLT-Bericht, 13 ff.
} 
und weiterentwickeln kann. ${ }^{9}$ Gleichermassen im Zentrum des Schweizer Regulierungsansatzes liegen die Sicherstellung der Integrität und Reputation des Schweizer Finanz- und Wirtschaftsstandorts. ${ }^{10}$

\section{Erkenntnisse}

\section{a) Im Allgemeinen}

Der Bundesrat kam zum Zeitpunkt der Verabschiedung der Botschaft (November 2019) zum Schluss, dass keine Notwendigkeit bestehe, den Schweizer Rechtsrahmen grundlegend anzupassen oder ein umfassendes, spezifisches Gesetz für DLT/Blockchain einzuführen. ${ }^{11}$

Dass der geltende Rechtsrahmen grundsätzlich geeignet ist, mit DLT und Blockchain umzugehen, zeigt sich in der Praxis unter anderem daran, dass sich in der Schweiz in den letzten Jahren - namentlich im Finanzbereich - ein ausgeprägtes Ökosystem mit innovativen Unternehmen im DLT/BlockchainBereich entwickelt hat. ${ }^{12}$ Freilich stellen die rechtlichen Rahmenbedingungen dabei nur einen von mehreren Faktoren für diese Entwicklung dar.

Auch die grundsätzliche Eignung des bestehenden Rechtsrahmens für DLTund Blockchain-Anwendungen dürfte auf mehrere Gründe zurückzuführen sein. Aus der Optik des Zivil- und Finanzmarktrechts im Vordergrund stehen dabei zwei Merkmale, namentlich der prinzipienbasierte (statt regelbasierte) sowie der technologieneutrale Rechtsetzungs- und Regulierungsansatz.

\section{b) Im Besonderen: Im Zivilrecht}

\section{aa) Schriftformerfordernis bei der Übertragung von Rechten als Hindernis}

Die Arbeitsgruppe Blockchain/ICO setzte sich u.a. zum Ziel, die ICO-Praxis aus zivilrechtlicher Perspektive zu analysieren. Dabei ging es in erster Linie darum, die gelebte Praxis rechtlich einzuordnen und im Sinne des Schaffens bestmöglicher Rahmenbedingungen allfällige Lücken oder Hindernisse im Zivilrecht zu identifizieren. Erfreulicherweise erschienen während der Tätig-

\footnotetext{
$9 \quad$ BBl 2020, 239.

$10 \quad$ BBl 2020, 239.

$11 \quad \mathrm{BBl} 2020,240$.

12 Vgl. bspw. die regelmässig publizierte Swisscom FinTech Startup-Infografik, abrufbar unter <https://www.swisscom.ch/de/business/enterprise/downloads/banking/monthly-fintech-startup-market-map.html>. Per Januar 2020 wurden von insgesamt 131 von 363 Unternehmen dem DLT-Bereich zugeordnet.
} 
keit der Arbeitsgruppe eine Vielzahl von wissenschaftlichen Publikationen, welche diese Analyse unterstützen. ${ }^{13}$ Auch leistete die private Brancheninitiative „Blockchain Taskforce“ wertvolle Vorarbeiten. ${ }^{14}$

Nachdem erste Publikationen die Ausgabe von Token vorwiegend von der technischen Seite her analysierten und die besonderen Eigenheiten von Token betonten, setzte sich in der Literatur zunehmend die Auffassung durch, dass weniger die Form als vielmehr der rechtliche Inhalt der Token für deren Qualifikation entscheidend sein müsse. Namentlich die Qualifikation von Daten ${ }^{15}$ oder Token ${ }^{16}$ als Sachen im Sinne des Sachenrechts wurde zunehmend verworfen: Nach überwiegender Auffassung sind aufgrund der fehlenden Körperlichkeit digitaler Daten die Regeln des Sacheigentums nicht anwendbar. Der Sachbegriff des Schweizer Rechts erfasst nur dreidimensionale, körperlich greifbare Gegenstände. ${ }^{17}$ Ausgangspunkt der Analyse der Arbeitsgruppe waren deshalb die Rechtsbeziehungen, welche der Ausgabe von Token zugrunde liegen und der Zweck, welche die Parteien mit der Ausgabe von Token verfolgen.

Die FINMA hat in ihrer Wegleitung für Unterstellungsanfragen betreffend ICOs vom 16. Februar 2018 ebenfalls einen funktionellen Ansatz gewählt. Sie unterscheidet zwischen Zahlungs-, Nutzungs- und Anlage-Token. Im DLTBericht vom Dezember 2018 präsentierte der Bundesrat die Schlussfolgerung, dass aus zivilrechtlicher Sicht zwei Hauptkategorien von Token zu unterscheiden sind: die Kryptowährungen (z.B. der Bitcoin) einerseits und die Token, die ein Recht (z.B. eine Forderung, eine Mitgliedschaft bei einer Gesellschaft) abbilden sollen andererseits (hier genannt Gegenpartei-Token). Aus zivilrechtlicher Sicht sind auch Nutzungs-Token, welche etwa einen Zugang zu einer digitalen Dienstleistung vermitteln sollen, in der Regel als Gegenpartei-Token zu qualifizieren. Sie verkörpern eine werkvertrags- oder auftragsähnliche Forderung.

13 Vgl. nur das umfangreiche Literaturverzeichnis im DLT-Bericht des Bundesrates.

14 Vgl. Blockchain Taskforce, Positionspapier zur rechtlichen Einordnung von ICOs, April 2018. Kann abgerufen werden unter $<$ https://blockchainfederation.ch/downloads/>.

15 Vgl. nur FrÖHLICH-BleUler, 13 ff.; HÜRLIMANN/ZeCH, Rz 8; HÜRLIMANN-KaUP, 142 ff.; R. H: WEBER, 30; R. H. WEBER/THOUVENIN, 49; a.A. ECKERT, 245 ff.

16 Vgl. u.a. BÄrTSCHI/MEISSER, 141; EGGEN, Was ist ein Token?, 561 ff.; ESSEBIER/BOURGEOIS, 579; Hauser-SpüHler/Meisser, 9; Hürlimann-Kaup, 142 ff.; Hess/Spielmann, 195 f.; Gless/ Kugler/Stagno, 90; Gobat, 1098; Maurenbrecher/Meier, Rz 20; Meisser/Meisser/Kogens, Rz 5 f.; MÜlLer/Reutlinger/Kaiser, 86 f.; von Der Crone/Kessler/Angstmann, 339 f.; WEBER, 30 .

17 REY, Rz 66 ff., 81; SCHMID/HÜRLIMANN-KAUP, Rz 7. 
Bei der Übertragung von Gegenpartei-Token hat der Bundesrat eine erhebliche Rechtsunsicherheit festgestellt. ${ }^{18}$ Sowohl Art. 165 Abs. 1 OR - für einfache Forderungen - als auch Art. 973c Abs. 4 OR - für die unkörperlichen Wertpapiere (sog. Wertrechte) - halten klar fest, dass es zu ihrer Übertragung einer schriftlichen Abtretungserklärung bedarf. Das bedeutet grundsätzlich, dass es die Unterschrift der abtretenden Person braucht (Art. 13 Abs. 1 OR), wobei diese entweder eigenhändig (Art. 14 Abs. 1 OR) oder mittels qualifizierter elektronischer Signatur (Art. 14 Abs. $2^{\text {bis }} \mathrm{OR}$ ) anzubringen ist. Zwar gibt es in der Lehre zwischenzeitlich auch innovative Ansätze, wie solche Rechte auch ohne Unterschrift übertragen werden können, so etwa im Rahmen einer Vertragsübertragung mit der Zustimmung aller Beteiligten. ${ }^{19}$ Es konnte sich jedoch dazu noch keine gefestigte Mehrheitsmeinung herausbilden, so dass unsicher ist, wie Gerichte in einem Einzelfall entscheiden würden. Der Bundesrat hat sich denn auch schon im DLT-Bericht vom Dezember 2018 bereit erklärt, eine Anpassung des Wertpapierrechts vorzuschlagen, um den Übergang von Rechten in dezentralen Registern rechtssicher zu ermöglichen. ${ }^{20}$ Von diesem gesetzlichen Formhindernis abgesehen, besteht im Privatrecht dagegen - wie nachfolgend näher dargelegt wird - kein dringender gesetzgeberischer Handlungsbedarf. Das Schweizer Privatrecht mit seinen Generalklauseln und dem vorherrschenden Prinzip der Vertragsfreiheit kann auch für neue Phänomene passende Lösungen bieten.

\section{bb) Kein Handlungsbedarf bei der Übertragung von Kryptowährungen}

Nach der wohl herrschenden Lehre stellen virtuelle Zahlungsmittel rein faktische, immaterielle Vermögenswerte dar. ${ }^{21}$ Sie sind keine dreidimensionalen, greifbaren Gegenstände und können deshalb grundsätzlich nicht den Sachen zugeordnet werden. ${ }^{22}$ Auch verfügen sie über keine eindeutige Gegenpartei und können deshalb nicht ohne Weiteres den Forderungen zugeordnet werden. Sie basieren aber auf dem Einverständnis ihrer Nutzer ${ }^{23}$ und haben nur so lange einen Wert, wie sie in dieser Gemeinschaft anerkannt werden. Auch wenn diese Werte selber keine Forderungen darstellen, so sind sie doch vertraglichen Vereinbarungen zugänglich. Sie können Gegenstand von Verträgen sein, bei denen eine Partei Güter oder Dienstleistungen in einer Kryptowäh-

\footnotetext{
18 DLT-Bericht, $62 \mathrm{ff}$.

19 Vgl. vOn DER CRONE/Kessler/Angstmann, $343 \mathrm{ff}$.

20 DLT-Bericht, $67 \mathrm{f}$.

21 Vgl. EgGen, Was ist ein Token?, 562 f.; Gobat, 1098 f.; Müller/ReUtlinger/Kaiser, 86 f.

22 Vgl. oben Fn. 17.

23 Vgl. Müller/ReutLinger/KAiser, 81.
} 
rung bezahlen will. ${ }^{24}$ Dafür genügt es grundsätzlich, dass der Gläubiger diese Währung annimmt und dass die Transaktion über das jeweilige Register (z.B. die Bitcoin-Blockchain) erfolgt, wobei der Wille der Vertragsparteien im Einzelfall - namentlich bei Schwierigkeiten in der Vertragsabwicklung - genau zu ermitteln ist. ${ }^{25}$ Der Begriff "Geld“ ist zivilrechtlich nicht genau definiert und muss für jede Bestimmung einzeln ausgelegt werden ${ }^{26}$ In Bezug auf den Bitcoin ist der Bundesrat im Bericht zu den virtuellen Währungen von 2014 zum Schluss gekommen, diese Kryptowährung erfülle zwar die obgenannten Funktionen von Geld bis zu einem gewissen Grad, könne aber wegen ihrer hohen Volatilität gegenüber offiziellen Währungen nicht als solches anerkannt werden. ${ }^{27}$ Diese Einschätzung wird vielfach nicht geteilt. ${ }^{28}$ Sie wirkt sich zivilrechtlich aber nicht auf Geschäfte mit Bitcoins aus. Es ist vielmehr im Einzelfall zu bestimmen, ob mit einer Kryptowährung bezahlt werden kann und wie diese Leistung zu qualifizieren ist.

Da Kryptowährungen weder den Sachen, noch den Forderungen zugerechnet werden können, ist für ihre Übertragung weder eine körperliche Übergabe noch eine schriftliche Abtretungserklärung (Art. 165 Abs. 1 OR) gefordert. Mangels klarer gesetzlicher Regelung ist davon auszugehen, dass der Aspekt der Übertragung der Vertragsfreiheit überlassen ist. Auch der Bundesrat ist zum Schluss gekommen, dass für die Übertragung von Kryptowährungen keine Lücken im Zivilrecht bestehen, die gesetzgeberisch gefüllt werden müssten. ${ }^{29}$

\section{cc) Kein Handeln angezeigt bei der Abbildung und Übertragung von dinglichen Rechten}

Für die Übertragung von Eigentum an einer Sache ist in der Regel die Übergabe der Sache vorausgesetzt. Durch den Besitzerwechsel wird der Eigentumsübergang Dritten gegenüber sichtbar, man spricht diesbezüglich vom Publizitätsprinzip. ${ }^{30}$ Mit der Übertragung von Token kann deshalb in der Regel kein Eigentum an einer Sache verschafft werden. In gesetzlich vorgesehenen Ausnahmefällen können auch Registereinträge das Publizitätsprinzip erfül-

24

BäRTSCHI/MEISSER, 145; EGGEN, Verträge über digitale Währungen, Rz 15.

EGGEN, Verträge über digitale Währungen, Rz 15 ff.; HAUSER-SpÜHLER/MEISSER, 6 ff., 7.

EGGEN, Verträge über digitale Währungen, Rz 5; PILLER, 1428.

Bericht des Bundesrates vom 25. Juni 2014 zu virtuellen Währungen in Beantwortung der Postulate Schwaab (13.3687) und Weibel (13.4070), abrufbar unter <www.parlament.ch> > Ratsbetrieb > Suche Curia Vista > Geschäfts-Nr. 13.3687, S. 10; vgl. weiter WEBER/TAKACS, 37. U.a.: HAuSER/Meisser, Digma 2018/1, 6 ff., 7; Gless/Kugler/Stagno, recht 2005, 87 f.; PiLLER, 1428; SCHÖNKNECHT, 309.

DLT-Bericht, $66 \mathrm{f}$.

REY, Rz 1720 f. 
len, ${ }^{31}$ Beispiele sind das Grundbuch beim Grundeigentum ${ }^{32}$, sowie die Register bei der Verpfändung von Vieh ${ }^{33}$, Schiffen ${ }^{34}$ und Luftfahrzeugen ${ }^{35}$ sowie beim Eigentumsvorbehalt ${ }^{36}$. Diese Register werden jedoch von amtlichen Stellen geführt. Die Nutzung von Distributed Ledger-Technologie für solche Register wäre zwar theoretisch denkbar, bedürfte jedoch vielfältiger gesetzlicher Anpassungen. Der Bundesrat hat ausgeführt, dass er für solche Anpassungen aktuell keinen Anlass sieht. ${ }^{37}$

Es gibt jedoch Konstellationen, in denen jemand Eigentümer ist, der eine Sache nicht unmittelbar besitzt und tatsächlich beherrscht, so beispielsweise, wenn ein Dritter die Sache für den Eigentümer verwahrt. Man spricht in solchen Fällen von mittelbarem (beim Eigentümer) und von unmittelbarem Besitz (beim Verwahrer). Auf diese Weise können auch Teile einer Sache mittelbar besessen werden, wenn die Sache für mehrere Miteigentümer verwahrt wird. ${ }^{38}$ Miteigentum kann auch entstehen, wenn bewegliche Sachen verschiedener Eigentümer gemeinsam verwahrt und miteinander vermischt werden. ${ }^{39}$ Auch die Sammelverwahrung von Wertpapieren führt nach Rechtsprechung und Lehre zu Miteigentumsanteilen am Gesamtbestand des Sammeldepots, man spricht von modifiziertem, labilem Miteigentum. ${ }^{40}$ In solchen Konstellationen kann auch die Übertragung von Eigentum ohne Übergabe der Sache erfolgen und es eröffnen sich Anwendungsmöglichkeiten für die Distributed Ledger-Technologie.

Der Eigentümer, der eine Sache von einem Dritten aufbewahren lässt, bleibt mittelbarer Besitzer der Sache, während der Dritte den unmittelbaren Besitz ausübt. Soll nun die Sache veräussert aber trotzdem weiterhin von dem Dritten verwahrt werden, reicht dafür die Übertragung des mittelbaren Besitzes mittels einer sogenannten Besitzanweisung aus. ${ }^{41}$ Der Veräusserer und der Erwerber schliessen einen Besitzanweisungsvertrag, der keinen Formerfordernissen unterliegt, und übertragen damit das Eigentum. Dem unmittelbaren Besitzer gegenüber wird der Eigentumsübergang dann wirksam, wenn er ihm

\footnotetext{
Vgl. HRubesch-Millauer/Graham-Siegenthaler/Roberto, Rz 01.56.

Art. 937 Abs. 1 ZGB.

Art. 885 ZGB.

Bundesgesetz über das Schiffsregister; SR 747.11.

Bundesgesetz über das Luftfahrzeugbuch; SR 748.217.1.

Art. 715 ZGB.

DLT-Bericht, $84 \mathrm{f}$.

Art. 646 Abs. 1 ZGB

Art. 727 Abs. $1 \mathrm{ZGB}$.

BGE 112 II 406 E. 4; REY, Rz 639 f. und 1941 ff.; MEIER-HAYOZ/VON DER CRONE, Rz 1320.

Art. 924 Abs. 1 ZGB.
} 
angezeigt wird. ${ }^{42}$ Die Besitzanweisung kann in einem Wertpapier verbrieft werden, was typischerweise bei Warenpapieren der Fall ist. ${ }^{43}$ Der Lagerhalter verpflichtet sich darin, den unmittelbaren Besitz an der Ware für den jeweiligen Besitzer des Warenpapiers auszuüben. Die Übertragung des mittelbaren Besitzes an der Ware (und damit des Eigentums) kann durch Übergabe des Warenpapiers erfolgen, eine Anzeige an den unmittelbaren Besitzer der Ware erübrigt sich in diesen Fällen. ${ }^{44}$ Wenn es der klare Wille der Parteien ist, das Eigentum an einer von einem Dritten verwahrten Sache bzw. eines Teils derselben durch Übertragung eines Token zu übertragen, kann die Übertragung des Token als Ausdruck eines formlos abgeschlossenen Besitzanweisungsvertrags verstanden werden.

Wichtig ist, dass allfällige Formvorschriften beachtet werden. Eine Übertragung von Eigentum mittels Token ist nur dort möglich, wo die Übertragung des Besitzes mit einem formlosen Rechtsgeschäft erfolgen kann. Demgegenüber ist beispielsweise für die Begründung von Miteigentum an Immobilien die öffentliche Beurkundung sowie die Eintragung in das Grundbuch vorgeschrieben. ${ }^{45}$

Der Bundesrat hat bereits im DLT-Bericht die Absicht geäussert, die Übertragung von Rechten, welche in Wertpapieren verbrieft werden können zu ermöglichen, für dingliche Rechte wie Sacheigentum jedoch nicht gesetzgeberisch tätig zu werden. ${ }^{46}$ In der Botschaft zur DLT-Vorlage hat er dazu folgendes ausgeführt: ${ }^{47}$

" [...] eine Verbriefung dinglicher Rechte ist nur beim Schuldbrief und dem Anleihenstitel mit Grundpfandrecht möglich. Bei Warenpapieren wird nicht das dingliche Recht an der Ware selbst, sondern der obligatorische Herausgabeanspruch auf die Ware verbrieft. Dingliche Rechte wie das Eigentum an Fahrnis können damit auch weiterhin weder durch einen Titel abgebildet noch über diesen Titel gehandelt werden. Die digitale Abbildung und Übertragung von Eigentum an real und parallel existierenden Sachen würde eine Vielzahl schwieriger Rechtsfragen aufwerfen. Ausgeklammert werden Konstellationen mit gestuftem Besitz, bei denen eine Übertragung von Eigentum durch Rechtsgeschäft bereits nach geltendem Recht möglich ist. Es erscheint denkbar, dass diese rechtsgeschäftliche Übertragung - ebenfalls bereits nach geltendem Recht - durch eine Registertransaktion erfolgen kann. Der Bun-

Art. 924 Abs. 2 ZGB.

Art. 1153 ff. OR.

Vgl. ZK-OFTINGER/Bär, Art. 902 ZGB N 21.

Art. 656 f. ZGB

DLT-Bericht, $67 \mathrm{f}$.

BBl 2020277.
} 
desrat hat für diese Konstellationen den zivilrechtlichen Handlungsbedarf deshalb verneint. Für Warenpapiere, die die Verbriefung und Übertragung von mittelbarem Besitz und damit dem Eigentum an Waren erlauben, wird eine Gesetzesänderung vorgeschlagen, welche die Ausgabe als Registerwertrecht ermöglicht."

Der Bundesrat schlägt somit vor, den Parteien mit der neuen Technologie nicht mehr - aber auch nicht weniger - zu ermöglichen, als bisher mit einem Papier möglich war. Damit wird dem gewählten prinzipienbasierten und technologieneutralen Ansatz nachgelebt.

\section{c) Im Besonderen: Im Insolvenzrecht}

Da Token weder den Sachen noch den Forderungen eindeutig zugeordnet werden können ${ }^{48}$ herrscht über ihre Behandlung im Konkursfall eine gewisse Rechtsunsicherheit. Nach Art. 197 Abs. 1 SchKG fällt sämtliches pfändbares Vermögen, das dem Schuldner zur Zeit der Konkurseröffnung gehört, in die Konkursmasse. Für Token, die einen Vermögenswert haben und dem Schuldner eindeutig gehören, stellen sich damit grundsätzlich keine rechtlichen Probleme. ${ }^{49}$ Unklarheiten bestehen jedoch dort, wo sich Token in der Verfügungsmacht eines Konkursschuldners befinden, die ihm nicht wirtschaftlich gehören. Die Aussonderungsregeln für Sachen und für anvertraute Forderungen können hier nicht ohne Weiteres angewendet werden. Der Bundesrat hat deshalb im DLT-Bericht die Einführung eines Aussonderungsrechts für Token vorgeschlagen. ${ }^{50}$ Der Bundesrat hat jedoch auch festgestellt, dass die Unsicherheit im Konkursrecht über Blockchain-Anwendungen hinausgeht. Auch andere Daten, die man von Dritten (z.B. einem Cloud-Provider) verwahren lässt, könnten von einem Konkurs dieses Dritten betroffen sein. Das Thema befindet sich auch schon länger auf der politischen Agenda, so hatte Nationalrat Marcel Dobler 2017 die parlamentarische Initiative 17.410 „Daten sind das höchste Gut privater Unternehmen. Datenherausgabe beim Konkurs von Providern regeln" eingereicht, welcher mittlerweile beide Räte Folge gegeben haben..$^{51}$ Der Bundesrat sprach sich aufgrund des engen thematischen Zusammenhangs dafür aus, das Anliegen dieser Initiative in die DLT-Arbeiten mit aufzunehmen.

\footnotetext{
48 Siehe oben, II.2.b)aa).

49 GoBAT, $1100 \mathrm{ff}$.

50 DLT-Bericht, $72 \mathrm{ff}$.

51 Abrufbar unter $<$ http://www.parlament.ch $>>$ Ratsbetrieb $>$ Suche Curia Vista > GeschäftsNr. 17.410.
} 


\section{d) Im Besonderen: Im Finanzmarktrecht}

DLT-basierte Anwendungen bzw. Geschäftsmodelle können zahlreiche Berührungspunkte zum Finanzmarktrecht aufweisen. So unter anderem zum Bankenrecht, Finanzmarktinfrastrukturrecht, Kollektivanlagenrecht, Versicherungsrecht sowie zum Finanzdienstleistungsgesetz und Finanzinstitutsgesetz. Die Zielsetzungen des Finanzmarktrechts - wie der Schutz der Funktionsfähigkeit der Finanzmärkte und der Schutz der Kundinnen und Kunden - sind dabei für Aktivitäten von DLT-Unternehmen im Finanzsektor gleichermassen relevant wie für alle andern Finanzmarktakteurinnen und -akteure.

Wie in der Botschaft ausgeführt, sieht der Bundesrat derzeit jedoch keine grundsätzlichen Probleme im Finanzmarktrecht, die DLT-basierte Anwendungen spezifisch betreffen und grundlegende Anpassungen erforderlich machen würden. ${ }^{52}$ Gleichwohl erscheinen auch im Finanzmarktrecht in einzelnen Bereichen gezielte Anpassungen sinnvoll. ${ }^{53}$

\section{Die DLT-Vorlage des Bundesrates vom November 2019}

I. Zivilrecht

a) Ausgangslage

Am 27. November 2019 verabschiedete der Bundesrat den Gesetzesentwurf und die Botschaft zum Bundesgesetz zur Anpassung des Bundesrechts an Entwicklungen der Technik verteilter elektronischer Register an das Parlament. ${ }^{54}$ Die Vorschläge im Zivilrecht haben das Ziel, die festgestellte rechtliche Unsicherheit bei der Übertragung von Rechten mittels Token sowie bei deren Behandlung in einem Konkursverfahren zu beheben. Das BJ und das SIF konnten bei der Ausarbeitung des Vorentwurfs und des Entwurfs dabei auf die Unterstützung von zahlreichen hochkarätigen Expertinnen und Experten zählen, welche ihr Expertenwissen in einer Reihe von Gesprächsrunden zur Verfügung gestellt haben. ${ }^{55}$

\footnotetext{
$52 \quad \mathrm{BBl} 2020,248$.

53 Vgl. unten, III.2.

54 BBl 2020, $233 \mathrm{ff}$.

55 Vgl. Botschaft, BBl 2020, $241 \mathrm{ff}$.
} 


\section{b) Wertpapierrecht}

aa) Konzept

Der Bundesrat schlägt vor, Registereinträge (Token) grundsätzlich wie Wertpapiere zu behandeln. Ein Schuldner verspricht etwas für die Zukunft und gibt dem Gläubiger dafür eine in einem Register abgebildete Wertmarke, die diese zukünftige Leistung verkörpern soll: das ist im Prinzip der gleiche Vorgang, wie wenn die Parteien vereinbaren, dass ein Recht in einem Papier verkörpert wird und nur mit diesem Papier übertragen werden soll (Art. 965 OR). ${ }^{56}$ Der Bundesrat schlägt die Schaffung einer neuen Kategorie im Wertpapierrecht vor, damit Parteien eines Vertrags oder einer Gesellschaft unter bestimmten Voraussetzungen vereinbaren können, ein Recht in einem Register abzubilden und die Übertragung in diesem Register anzuerkennen.

Die vorgeschlagenen Änderungen sind im allgemeinen Wertpapierrecht eingeordnet und betreffen alle Wertpapierarten, unabhängig davon, welche Rechte verkörpert sind. Geschaffen wird ein neues, allgemeines Gefäss. Punktuelle Anpassungen sind bei den speziellen Wertpapierkategorien der Aktien und der Warenpapiere nötig, damit dieses neue Gefäss für diese Kategorien ebenfalls verwendet werden kann.

Dieser Ansatz - die Fokussierung auf die Rechtsbeziehung, die dem Token zugrundeliegt (d.h. die Beziehung zwischen Schuldner und Gläubiger) - hat seine Wurzeln im Vertragsrecht. Dies trifft auch für das Kern-Wertpapierrecht - welches im Obligationenrecht angesiedelt ist - zu. Im zivilrechtlichen Wertpapierrecht ist auch keine Aufsichtsbehörde vorgesehen; die Privaten sind bei der Verbriefung von Rechten grundsätzlich frei. Das Finanzmarktrecht mit seinen Zielen des System- und Anlegerschutzes knüpft nicht primär beim Wertpapier, sondern bei der Effekte an: bei der Ausgabe von vereinheitlichten und zum massenweisen Handel geeigneten Papieren. Diese Anknüpfung erfolgt dabei unabhängig von der Form, welche der Effekte zugrundeliegt. Diese Aufteilung wurde grundsätzlich auch für das neue Gefäss beibehalten.

\section{bb) Anforderungen an Register und Adressierung von Risiken}

Nach dem Grundprinzip des Wertpapierrechts sind die Parteien frei, ein Recht mit einer Urkunde zu verknüpfen und dieser Urkunde somit weitgehende Rechtswirkungen zu verleihen. An die Urkunde selbst werden vom Gesetz keine Anforderungen gestellt, es genügt grundsätzlich jedes physische Objekt, 
das Träger einer Erklärung sein kann.$^{57}$ Der Bundesrat schlägt aufgrund der spezifischen technischen Risiken jedoch vor, an das neue Wertrechteregister gemäss DLT-Vorlage gewisse Mindestanforderungen zu stellen. Dass es solche Mindestanforderungen braucht, war auch in der Vernehmlassung nahezu unbestritten. ${ }^{58}$ Die Art, wie diese Mindestanforderungen im Vorentwurf formuliert waren, gab jedoch zu weit verbreiteter Kritik Anlass. ${ }^{59}$ Die Anforderungen wurde als zu technologiespezifisch und stellenweise als unnötig empfunden. So wurde namentlich bemängelt, dass das Register nach dem Vorentwurf dem neuesten Stand der Technik hätte genügen müssen, ohne dass damit in jedem Fall ein Sicherheitsgewinn einhergegangen wäre. Im Entwurf wurde deshalb noch stärker versucht, die zentralen Aspekte, die eine Angleichung an ein physisches Papier rechtfertigen, herauszuschälen. Die Verwaltung hat dazu erneut Expertinnen und Experten - diesmal mit einem stärkeren Fokus auf den technischen Bereich - beigezogen. ${ }^{60}$ In verschiedenen Gesprächsrunden hat sich gezeigt, dass es äusserst schwierig ist, eine Balance zwischen genügend klaren Vorgaben - was punkto Rechtssicherheit erforderlich ist und der angestrebten Technologieneutralität zu finden. Schlussendlich wurden im bundesrätlichen Entwurf Mindestanforderungen mit folgenden Kernelementen abgebildet:

- Verfügungsmacht: Mit dem Element der Verfügungsmacht - bzw. der Beherrschbarkeit - wird verlangt, dass die Gläubiger, nicht aber der Schuldner, die Verfügungsmacht über ihre Rechte haben sollen (Art. 973d Abs. 2 Ziff. 1 E-OR). Damit rechtfertigt sich die Analogie zum Wertpapier, welches vom Schuldner ausgestellt, dann aber dem Gläubiger übergeben wird. ${ }^{61}$ Dieses Element wurde nach dem Vernehmlassungsverfahren neu eingeführt. Es erlaubt die Abgrenzung gegenüber einer Vielzahl anderer elektronischer Register (z.B. einer rein internen Buchhaltung), welchen nicht ohne Weiteres wertpapierrechtliche Wirkungen zuerkannt werden können. Ergänzend bleibt anzufügen, dass derzeit Abklärungen zu einer weiteren Öffnung des Wertpapierrechts im Gange sind. ${ }^{62}$

- Integrität: Das Wertrechteregister muss die Rechtslage korrekt abbilden und darf nicht einseitig manipulierbar sein, dieses Erfordernis ist zentral. Da jedoch in technischen Belangen - wie auch im übrigen Leben - eine

MeIer-Hayoz/von der Crone, Rz 6 ff.; CHK-Kuhn, Art. 965 N 19, je m.w.H; vgl. auch DLTBericht, $57 \mathrm{f}$.

58 DLT-Ergebnisbericht, $6 \mathrm{f}$.

59 DLT-Ergebnisbericht, $7 \mathrm{f}$.

60 BBl 2020, 242.

61 Vgl. Kuhn/Stengel/Meisser/Weber, Rz 15.

62 BBl 2020, $244 \mathrm{f}$. 
hundertprozentige Sicherheit nicht möglich ist und deshalb von Gesetzes wegen auch nicht verlangt werden kann, musste eine Möglichkeit gefunden werden, um dieses hohe Sicherheitsanfordernis klar aber erfüllbar zu beschreiben. Eine technologieneutrale Formulierung scheint hier besonders schwer zu finden, zeichnen sich verteilte elektronische Register doch gerade durch ihre besondere Sicherheit aus. Der Bundesrat schlägt vor, verteilte elektronische Register als Standard und best practice im Gesetz zu nennen, damit klar wird, welches Sicherheitsniveau erwartet wird. Die gemeinsame Datenverwaltung durch mehrere, voneinander unabhängige Teilnehmer soll jedoch nicht eine zwingende Voraussetzung sein (vgl. Art. 973d Abs. 2 Ziff. 2 E-OR). Es ist damit nicht ausgeschlossen, dass auch andere Register diesen Sicherheitsstandard in Zukunft erfüllen können. In der Botschaft werden beispielhaft einige Register genannt, welche Ende 2019 nach Expertenmeinung einen angemessenen Schutz vor Manipulationen bieten konnten, darunter die Bitcoin-Blockchain, Ethereum sowie Cardano, Algorand, Corda und Hyperledger Fabric. ${ }^{63}$

- Transparenz: Wie bei einem klassischen, physischen Wertpapier muss der Inhalt des verbrieften Rechts sowohl für die ursprünglichen Parteien als auch für allfällige Dritte, die das Recht erwerben möchten, ersichtlich sein. Im Entwurf wird verlangt, dass diese Informationen im Wertrechteregister selbst oder in damit verknüpften Begleitdaten festhalten sind (Art. 973d Abs. 2 Ziff. 3 E-OR). Dort muss auch die Funktionsweise des Registers, die Art, wie neue Buchungen ausgelöst und validiert werden, festgehalten sein. Die Gläubiger müssen die sie betreffenden Informationen und Registereinträge direkt einsehen und deren Richtigkeit (Integrität) ohne Zutun Dritter überprüfen können (Art. 973d Abs. 2 Ziff. 4 E-OR).

Der Umgang mit Risiken erfolgt nach dem gewählten zivilrechtlichen Konzept in einer ersten Linie durch Haftungsregeln. Die Parteien sind frei, ihre Rechte in einem Wertrechteregister abzubilden und sie in diesem Register zu handeln, sie müssen sich jedoch über die damit verbundenen Risiken im Klaren sein. Das Ziel einer neuen zivilrechtlichen Regelung sollte es auch sein, diese Risiken möglichst gerecht zu verteilen. Der Entwurf sieht vor, dass der Schuldner (z.B. die Emittentin) die Gläubiger und zukünftigen Erwerber des Registerwertrechts über den Inhalt des Rechts, die Funktionsweise des Registers sowie die Massnahmen, die zum Schutz der Integrität und des Funktionierens des Registers ergriffen wurden, informieren muss (Art. 973i E-OR). Der Schuldner, welcher ein Recht über eine neue Technologie ausgeben möchte und die Wahl des Registers in der Regel in der Hand hat, wird damit in die Pflicht

BBl 2020, $281 \mathrm{f}$. 
genommen, die relevanten Informationen zu erheben und festzuhalten. Sofern er bei diesen Angaben nicht die erforderliche Sorgfalt anwendet, haftet er für Schäden, die aus seinen unrichtigen, irreführenden oder den gesetzlichen Anforderungen nicht genügenden Angaben entstehen. Von dieser Haftung soll sich der Schuldner nach dem Entwurf des Bundesrates gegenüber den Gläubigern nicht freizeichnen können, da nur so garantiert ist, dass die entsprechende Verantwortung auch wirklich wahrgenommen wird (Art. 973i Abs. 3 E-OR). Mit einer Freizeichnungsmöglichkeit wäre das Risiko gross, dass die Gefahren der neuen Technologie pauschal auf die Gläubigerinnen und Gläubiger, welche darauf kaum Einfluss nehmen könnten, überwälzt würden. Es steht dem Schuldner aber natürlich frei, sich seinerseits bei einem allfälligen Registerbetreiber oder einem anderen Beteiligten durch entsprechende vertragliche Vereinbarungen abzusichern. Die gesetzliche Haftungsnorm soll aus Ausgangspunkt dafür dienen, dass die technischen Risiken erkannt und dort getragen werden, wo sie beeinflusst werden können. Der Bundesrat hat hier die Erwartung geäussert, dass sich in absehbarer Zeit Branchenstandards entwickeln und die Parteien sich durch vorgängige unabhängige Überprüfung von Wertrechteregistern absichern werden. ${ }^{64}$

Durch die angemessene Verteilung der technischen Risiken können gute Rahmenbedingungen für die neue Technologie geschaffen werden, ohne dass damit neue staatliche Aufgaben übernommen werden müssten. Eine staatliche Aufsicht für den privatrechtlichen Vorgang der Wertpapierausgabe existiert bisher nicht und soll auch nicht neu geschaffen werden. ${ }^{65}$ Die Vertragsfreiheit soll im Zeitalter der Digitalisierung weiterhin - oder erst recht - im Zentrum stehen.

Die zivilrechtliche Fokussierung auf die vertragliche Beziehung Schuldner Gläubiger ist auch deshalb lohnenswert, weil es im DLT-Bereich oft keinen zentralen vertrauenswürdigen Registerführer gibt. Rechtlich kann deshalb teilweise niemand anderes als die beiden Vertragsparteien ins Auge gefasst werden. Für zivilrechtliche Belange ist diese Fokussierung auf die privatrechtlichen Parteien ausreichend. Das Ziel, das Hindernis des Schriftformerfordernisses zu beseitigen, wird erreicht und es eröffnen sich eine Vielzahl von Anwendungsmöglichkeiten (z.B. Ticketing- oder Parkplatzvermietungssysteme, Verwaltung von Lizenzen etc.). Im Finanzmarktrecht können jedoch unter Umständen weitergehende Anforderungen an ein Wertrechteregister angemessen sein. Für DLT-Effekten, also vereinheitlichte und zum massen- 
weisen Handel geeignete Registerwertrechte oder vergleichbare Wertrechte, wird deshalb die Möglichkeit vorbehalten, in einer Verordnung Mindestanforderungen hinsichtlich der Integrität und Publizität des zugrundeliegenden Registers vorzusehen (Art. 73d Abs. 3 E-FinfraG).

\section{cc) Wirkungen der Ausgestaltung als Registerwertrecht}

Die Wirkungen der Ausgestaltung als Registerwertrecht werden nach dem bundesrätlichen Entwurf einem Wertpapier öffentlichen Glaubens nachgebildet (Art. 973e-973h E-OR). Zentral ist hier der Gutglaubensschutz. Das Wertpapierrecht hält für eine Vielzahl von Fragen, die sich stellen können - z.B. zum Abhandenkommen von Wertpapieren (bzw. Zugangsschlüsseln) oder zum Diebstahl (bzw. Hacking) von Wertpapieren, bereits passende Lösungen bereit, die ohne grosse Änderungen adaptiert werden können. Das Denken in vertrauten Kategorien führt dabei zu einem hohen Mass an Rechtssicherheit. Bei allfälligen Auslegungsschwierigkeiten kann auf einen Fundus an Rechtsprechung und Lehre zurückgegriffen werden. Dieser Teil der Vorlage wurde nach der Vernehmlassung entsprechend nur leicht überarbeitet. ${ }^{66}$

\section{dd) Ausblick: Prüfung einer weiteren Öffnung bei der Übertragung von Rechten}

Die schnelle Verbreitung von DLT-Anwendungen hat gezeigt, dass das Schriftformerfordernis bei der Übertragung von Rechten möglicherweise nicht mehr zeitgemäss ist. ${ }^{67}$ Der Bundesrat schlägt mit den Registerwertrechten ein neues Gefäss vor, welches für DLT-Anwendungen und ähnlich gelagerte Systeme, welche Analogien zu traditionellen Wertpapieren zulassen, eine schnelle und passende Lösung bieten kann.

Möglicherweise wäre aber eine noch breitere Öffnung des Wertpapierrechts angemessen und das Schriftformerfordernis bei der Zession sollte womöglich ganz grundsätzlich überprüft werden (Art. 165 Abs. 1 OR). Der Bundesrat hat sich bereit erklärt, diese Abklärungen vorzunehmen und bei allfälligen Handlungsbedarf zu einem späteren Zeitpunkt weitere Gesetzesänderungen vorzuschlagen. ${ }^{68}$

\footnotetext{
66 Siehe dazu BBl 2020, $284 \mathrm{ff}$.

67 Siehe oben, II.2.b)aa).

68 BBl 2020, 245.
} 


\section{c) Insolvenzrecht}

Das vorgeschlagene Aussonderungsrecht ${ }^{69}$ für kryptobasierte Vermögenswerte und Daten wurde in der Vernehmlassung im Grundsatz fast einhellig begrüsst. Stark kritisiert wurde jedoch vor allem ein Aspekt: im Vorentwurf war verlangt worden, dass kryptobasierte Vermögenswerte jederzeit individuell im Register zuordenbar sein müssen, um aussonderbar zu sein. Damit würde bei den weit verbreiteten Sammelaufbewahrungen eine Aussonderung ausser Betracht fallen. Im Vernehmlassungsverfahren wurde von verschiedener Seite überzeugend dargelegt, dass damit möglicherweise gerade die sichersten und effizientesten Verwahrungslösungen verunmöglicht würden. ${ }^{70}$ Im Entwurf des Bundesrates wird nur noch verlangt, dass die Vermögenswerte dem Dritten entweder individuell zugeordnet sind oder einer Gemeinschaft zugeordnet sind und ersichtlich ist, welcher Anteil am Gemeinschaftsvermögen dem Dritten zusteht. Damit wird für kryptobasierte Vermögenswerte eine Lösung vorgeschlagen, welche für sammelverwahrte Wertpapiere seit langem Bestand hat. ${ }^{71}$ Die neue Lösung soll für sämtliche kryptobasierten Vermögenswerte gelten, welche für einen Dritten mit der Vereinbarung, sie jederzeit für ihn bereitzuhalten, verwahrt werden (Art. 242a Abs. 2 E-SchKG). Es ist im Konkursverfahren, in dem es um die Unterteilung von eigenen und fremden Vermögenswerten geht, gerechtfertigt, einen breiten Ansatz zu wählen und nicht nach dem Inhalt von Token zu differenzieren. Die Konkursverwaltung muss im Einzelfall eine klare Entscheidung treffen können. Die Unterscheidung danach, ob die Vermögenswerte für Dritte gehalten werden oder ob damit Eigengeschäfte betrieben werden dürfen, ist für die Unterteilung in eigene und fremde Vermögenswerte sachgerecht und kann ohne grösseren Aufwand getroffen werden. Eine konkursrechtliche Unterscheidung nach dem Inhalt der verwahrten Token wäre demgegenüber komplex und dürfte Anlass zu Rechtsstreitigkeiten geben.

Gegen diese Änderung zur Vernehmlassungsvorlage hatte - wie der bundesrätlichen Botschaft zu entnehmen ist - namentlich die FINMA Bedenken angemeldet. ${ }^{72}$ Der Grund dafür ist jedoch nicht im Konkursrecht zu suchen, sondern liegt an einer Eigenart des Schweizer Bankenrechts: als Hauptkriterium für die Bankentätigkeit gilt die gewerbsmässige Entgegennahme von Publikumseinlagen (Art. $1 a$ und $b$ BankG). Für die Qualifikation als Publikumseinlagen ist wiederum entscheidend, ob ein Vermögenswert aussonderbar ist.

\footnotetext{
69 Siehe oben, II.2.c).

70 DLT-Ergebnisbericht, $10 \mathrm{f}$.

71 Vgl. zum modifizierten labilen Miteigentum die Nachweise oben, Fn. 40.

$72 \mathrm{BBl} 2020,246 \mathrm{ff}$.
} 
Wird nun im Konkursrecht eine breite Aussonderungsmöglichkeit vorgesehen, könnte dies Auswirkungen auf die bankenrechtliche Qualifikation und letztlich auf die bankenrechtliche Bewilligungspflicht haben. Der Bundesrat hat jedoch entschieden, dass dies kein Hindernis für eine sachlich überzeugende Lösung im Konkursrecht sein darf, und schlägt stattdessen eine komplementäre Anpassung des Bankengesetzes vor. ${ }^{73}$

\section{d) Weiteres}

Schliesslich führt die Schaffung eines neuen Gefässes im Wertpapierrecht auch zu einer Anpassung im internationalen Privatrecht. In den für Wertpapiere einschlägigen Kollisionsnormen werden nun auch "gleichwertige Titel ${ }^{“}$ anerkannt (Art. 145a E-IPRG). Es liegt dann am jeweils anwendbaren materiellen Recht, zu bestimmen, ob ein solcher Titel tatsächlich als Wertpapier anerkannt wird und welche Wirkungen diese Anerkennung nach sich zieht.

Aufgrund von zahlreichen Rückmeldungen in der Vernehmlassung ${ }^{74}$ wurden zudem die neuen Registerwertrechte auch in das Bucheffektengesetz aufgenommen (Art. 5 Bst. g und h; Art. 6 E-BEG), so dass eine explizite Schnittstelle zwischen diesem neuen wertpapierrechtlichen Gefäss und den Bucheffekten besteht. Die Registerwertrechte werden im Bucheffektengesetz grundsätzlich gleich wie physische Wertpapiere behandelt. ${ }^{75}$

\section{Finanzmarktrecht}

\section{a) Ausgangslage}

Im Rahmen seiner Analysen ${ }^{76}$ kam der Bundesrat zum Schluss, dass im Finanzmarktrecht derzeit keine grundsätzlichen Probleme bestehen, die DLTbasierte Anwendungen spezifisch betreffen und grundlegende Anpassungen erfordern würden. ${ }^{77}$ Gleichwohl seien jedoch gezielte Anpassungen sinnvoll.

Im Finanzmarktrecht schlägt der Bundesrat die Schaffung einer neuen Bewilligungskategorie für (Finanzmarkt-)Infrastrukturanbieter im DLT-Bereich vor. ${ }^{78}$

\footnotetext{
73 Siehe unten, III.2.c)

74 DLT-Ergebnisbericht, 10.

$75 \quad \mathrm{BBl} 2020,308$.

76 Namentlich im Rahmen des DLT-Berichts vom Dezember 2018, des Erläuternden Berichts zur Vernehmlassungsvorlage vom März 2019 sowie der Botschaft vom November 2019.

77 Siehe oben, II.2.d).

78 Vgl. unten, III.2.b).
} 
Die DLT-Vorlage enthält sodann auch komplementäre Elemente, etwa im Finanzinstitutsgesetz und im Bankengesetz betreffend die Bewilligung nach Artikel $1 b$ Bankengesetz (sog. „Fintech-Lizenz“). ${ }^{79}$

Nicht Gegenstand der Vorlage sind dagegen Anpassungen im Kollektivanlagenrecht, im Versicherungsrecht ${ }^{80}$ oder im neuen Finanzdienstleistungsgesetz $^{81}$. Ebenfalls nicht Teil der DLT-Vorlage sind steuerrechtliche Aspekte. ${ }^{82}$

\section{b) Finanzmarktinfrastrukturrecht}

\section{aa) DLT-Handelssystem}

Kernelement des bundesrätlichen Vorschlags ist die Schaffung einer neuen Finanzmarktinfrastruktur im DLT-Bereich: das sog. DLT-Handelssystem. ${ }^{83}$ Diese neuartige Form einer Finanzmarktinfrastruktur wurde im Vernehmlassungsverfahren grossmehrheitlich unterstützt, vereinzelt aber auch kritisiert. $^{84}$

Die heutige Regulierung der Finanzmarktinfrastrukturen hat sich grundsätzlich bewährt. Der Bundesrat sieht demnach keinen Bedarf, die geltende Regulierung für Handelsplätze (Börsen und multilaterale Handelssysteme) ${ }^{85}$ sowie für Nachhandelsinfrastrukturen (insb. der Zentralverwahrer ${ }^{86}$ ) aufgrund von DLT und Blockchain grundlegend anzupassen. ${ }^{87}$

Gleichzeitig zeigt sich aber, dass mit DLT neue Möglichkeiten eröffnet werden, die Innovationspotenzial bieten - gerade auch im Bereich des Handels mit

\footnotetext{
79 Vgl. unten, III.2.c).

80 Vgl. BBl 2020, 249; weiterführend: DLT-Bericht, 132 ff. (zum Kollektivanlagenrecht), 138 (zum Versicherungsrecht).

81 Vorbehältlich einer technischen Anpassung der Legaldefinition der „Effekten“ in Art. 3 FIDLEG, die sich ihrerseits aus einer Anpassung derselben Legaldefinition in Art. 2 Bst. b FinfraG ergibt. Im parlamentarischen Prozess wurden sodann Anpassungen im Art. 29, 35 und 77 FIDLEG vorgenommen.

82 Vgl. weiterführend: BBl 2020, 241 (dort Fn. 6).

83 Vgl. Art. 73a ff. E-FinfraG (BBl 2020, 329 ff.).

84 Einzelne kritisierten die vorgeschlagenen Erleichterungen als zu weitgehend, andere selbige als zu wenig weitgehend; vgl. im Einzelnen: DLT-Ergebnisbericht, 13 ff.; ferner: BBl $2020,251 \mathrm{f}$.

85 Art. 26 ff. FinfraG.

86 Art. 61 ff. FinfraG.

87 BBl 2020, 272.
} 
Effekten $^{88}$ - und vom geltenden Finanzmarktinfrastrukturrecht teilweise nur beschränkt oder unzureichend erfasst werden. Im Finanzmarktinfrastrukturbereich betrifft dies namentlich zwei Themenkomplexe:

- Wer hat Zugang zur Finanzmarktinfrastruktur: Finanzmarktinfrastrukturen stehen heute typischerweise ausschliesslich finanzmarktrechtlich beaufsichtigten Marktakteuren als direkte Teilnehmer offen. ${ }^{89 / 90}$ Nicht beaufsichtigte (natürliche oder juristische) Personen haben entsprechend keinen Zugang zu einem Handelsplatz und sind darauf angewiesen, Effektenhandelsgeschäfte (an organisierten Märkten) über Intermediäre (meist Wertpapierhäuser) zu tätigen. ${ }^{91}$ Diese Form des intermediatisierten Zugangs entspricht den heute verbreiteten und gleichsam traditionellen Strukturen und Funktionsweisen der Finanzmärkte - in der Schweiz wie auch in vielen ausländischen Märkten.

Gleichzeitig erlauben moderne Technologien wie DLT oder Blockchain zunehmend direktere Formen des wirtschaftlichen Zusammenwirkens von Marktakteuren (z.B. mittels Peer to Peer-Transaktionen). Beim Handel mit Effekten über Blockchain- bzw. DLT-basierte Plattformen ist ein Umweg

88 Als Effekten gelten vereinheitlichte und zum massenweisen Handel geeignete Wertpapiere, Wertrechte, Derivate und Bucheffekten (Art. 2 Bst. b FinfraG). Die Vorlage des Bundesrates sieht einerseits vor, diese Legaldefinition um die neuen Registerwertrechte (Art. 973d EOR) zu erweitern (vgl. Art. 2 Bst. b E-FinfraG) sowie andererseits eine neue Legaldefinition für sog. „DLT-Effekten“ einzuführen (vgl. Art. 2 Bst. ${ }^{\text {bbis }}$ E-FinfraG).

Art. 34 Abs. 2 FinfraG definiert beispielsweise den Teilnehmerkreis einer Börse oder eines multilateralen Handelssystems. Als Teilnehmer zugelassen werden können danach: Wertpapierhäuser (nach Art. 41 FINIG); weitere von der FINMA Beaufsichtigte, von der FINMA bewilligte ausländische Teilnehmer sowie die SNB. Die bewilligten ausländischen Teilnehmer müssen dabei einer angemessenen Regulierung und Aufsicht (im Ausland) unterstehen (vgl. Art. 40 Abs. 1 Bst. a FinfraG).

90 Auch für Handelsplätze hat sich gezeigt, dass der im FinfraG vorgesehene Teilnehmerkreis zu eng gefasst ist. Eine gezielte Flexibilisierung der Teilnehmerregelung ist in der Vernehmlassungsvorlage zur Revision des Bankengesetzes (Insolvenz; Einlagensicherung, Segregierung) vom März 2019 enthalten: Danach soll ein Handelsplatz weitere Einrichtungen als Teilnehmer zulassen können, wenn diese (kumulativ) öffentliche Aufgaben wahrnehmen und in diesem Kontext auf eine Teilnahme am Handelsplatz angewiesen sind, über eine professionelle Tresorerie verfügen und der Handelsplatz für diese Teilnehmer die Einhaltung gleichwertiger technischer und operativer Voraussetzungen wie betreffend die Wertpapierhäuser sicherstellt. Für die Zulassung entscheidend ist, dass der Teilnehmer für die Wahrnehmung öffentlicher Aufgaben auf die Teilnahme angewiesen ist (vgl. Erläuternder Bericht vom 8. März 2019 zur Änderung des Bankengesetzes (Insolvenz; Einlagensicherung, Segregierung), 57.

91 Freilich können Handelsgeschäfte Over-the-Counter (OTC) auch ohne Intermediär abgeschlossen werden. 
über regulierte Finanzmarktteilnehmer aus technischen Gründen nicht mehr erforderlich. Gleichzeitig fehlt es heute aber oftmals an regulierten und beaufsichtigten Sekundärmärkten, die Privatkundinnen und -kunden zur direkten Teilnahme offenstehen. Entsprechend sind diese Kundinnen und Kunden gezwungen, auf nicht regulierte Handelsplätze (im Ausland) auszuweichen oder sich durch spezialisierte Unternehmen im Blockchain/ DLT-Bereich unterstützen zu lassen.

Vor diesem Hintergrund sieht der Entwurf vor, dass das DLT-Handelssystem gleichermassen Retail-Teilnehmerinnen und -teilnehmern wie auch beaufsichtigten Teilnehmern offen stehen können soll. ${ }^{92}$ Artikel 73c E-FinfraG beinhaltet die Regelung über die Zulassung von Teilnehmern. Dem Grundgedanken von Artikel 34 Absatz 2 FinfraG folgend können Wertpapierhäuser, von der FINMA oder einer ausländischen Behörde Beaufsichtige, die SNB sowie die Bank für Internationalen Zahlungsausgleich an einem DLT-Handelssystem teilnehmen. Zusätzlich - und hierin liegt die Neuerung - steht das DLT-Handelssystem auch weiteren natürlichen und juristischen Personen offen, sofern diese erklären, dass sie in eigenem Namen und auf eigene Rechnung am DLT-Handelssystem teilnehmen. ${ }^{93}$

- Was für Dienstleistungen werden erbracht: In der „klassischen Welt“ zentral organisierter Finanzmarktinfrastrukturen erfolgt oftmals eine trennscharfe Differenzierung zwischen Infrastrukturen zum Handel (z.B. Börsen) und nachgelagerten Infrastrukturdienstleistungen (z.B. Effektenabwicklungssystemen und Zentralverwahrung). ${ }^{94}$ Mit dem DLT-Handelssystem erfolgt eine Loslösung von einem „Silo“-basierten Verständnis der Finanzmarktinfrastrukturen, hin zu einem holistischen Ansatz: DLT erlaubt eine technologisch getriebene Konvergenz von Handels- und Nachhandelsdienstleistungen. Beispielswiese können Handel und Abwicklung eines Finanzgeschäfts (z.B. einer Effektentransaktion) zeitlich praktisch zusammenfallen und direkt auf einer einheitlichen, DLT-basierten Infrastruktur erfolgen.

Das DLT-Handelssystem wurde im Entwurf entsprechend so ausgestaltet, dass es - neben dem zwingend notwendigen Element des Handels mit spezifischen, DLT-basierten Effekten - auch weitere Dienstleistungen im

Vgl. DLT-Bericht, 114; BBl 2020, 272.

93 Vgl. Art. 73c Abs. 1 Bst. e E-FinfraG. Die Einschränkung, wonach die weiteren natürlichen und juristischen Personen ausschliesslich in eigenem Namen und auf eigene Rechnung teilnehmen dürfen erklärt sich mit Blick auf die Bekämpfung von Risiken im Bereich der Geldwäscherei und Terrorismusfinanzierung.

Damit soll verhindert werden, dass sich die Destabilisierung einer Finanzmarktinfrastruktur auf eine andere Finanzmarktinfrastruktur ausweiten kann oder dass Fehlanreize entstehen (vgl. DLT-Bericht, 115). 
Bereich der zentralen Verwahrung und Abwicklung von Effekten anbieten kann, die nach geltendem Recht in den Aufgabenbereich eines Zentralverwahrers ${ }^{95}$ fallen.

Zusammenfassend lässt sich festhalten, dass das DLT-Handelssystem eine gewerbsmässige Einrichtung zum Handel mit bestimmten Effekten ${ }^{96}$ ist. Wie bei Börsen und multilateralen Handelssystemen erfolgt dieser Handel auf multilateraler Basis und nach nichtdiskretionären Regeln. In Abgrenzung zur Börse und dem multilateralen Handelssystem muss das DLT-Handelssystem mindestens ein weiteres Qualifikationsmerkmal erfüllen, damit es als solches gilt: Es muss unbeaufsichtigte Teilnehmer zulassen, DLT-Effekten zentral verwahren oder solche Effekten zentral abrechnen und abwickeln. ${ }^{97}$ Mit der Schaffung des DLT-Handelssystems als neue Form einer Finanzmarktinfrastruktur spezifisch für den Handel mit DLT-basierten Effekten soll ein angemessener und flexibler Rechtsrahmen geschaffen werden. ${ }^{98}$

\section{bb) „Sandbox“ im Finanzmarktinfrastrukturrecht?}

Der Begriff „Sandbox“ wird im Finanzmarktrecht zwar regelmässig, aber auch uneinheitlich verwendet. Die Ausgestaltung finanzmarktrechtlicher Sandkästen unterscheidet sich in verschiedenen Dimensionen. Sandkästen lassen sich u.a. danach differenzieren, welche Spielregeln „im Sandkasten“ gelten bzw. von welchen (finanzmarkt-)rechtlichen Anforderungen die Unternehmen im Sandkasten befreit sind. Eine andere Dimension betrifft die Frage, welche Unternehmen von einer Sandbox profitieren können. In einzelnen Jurisdiktionen werden diese Plätze im Sandkasten kompetitiv vergeben und eine zuständige Behörde wählt (oft eine begrenzte Anzahl von) Unternehmen für eine Teilnahme im Sandkasten aus. Andere Ansätze sehen keine behördlichen Wahlmöglichkeiten vor, sondern etablieren objektive Kriterien für die Nutzung einer Sandbox.

\footnotetext{
95 Art. 61 FinfraG.

96 Zum Begriff der DLT-Effekten, vgl. Art. 2 Bst. bbis E-FinfraG.

97 Vgl. Art. 73a Abs. 1 E-FinfraG.

98 BBl 2020, 272
} 
Die Schweiz verfügt heute im Bankenrecht über einen sog. Innovationsraum, der auch als Sandbox verstanden wird. ${ }^{99}$ Im Finanzmarktinfrastrukturecht besteht demgegenüber kein mit dem Bankenbereich vergleichbarer Innovationsraum.

Im Rahmen der Arbeiten zu DLT wurde die Einführung einer Sandbox im Finanzmarktinfrastrukturecht mehrfach $^{100}$ geprüft und verworfen. ${ }^{101}$ Die Attraktivität der Schweiz für Blockchain- bzw. DLT-Projekte hängt in diesem Bereich weniger vom Vorhandensein einer Sandbox ab, als vielmehr davon, dass solchen Projekten zielgerichtete und angemessene finanzmarktregulatorische Rahmenbedingungen zur Verfügung gestellt werden. ${ }^{102}$ Der Bundesrat kam entsprechend zum Schluss, dass es zweckmässiger sei, die für Blockchain-/DLT-Anwendungen bestehenden Herausforderungen im Finanzmarktinfrastrukturrecht zielgerichtet durch spezifische Anpassungen (anstelle eines regulierungsfreien Bereichs) zu adressieren. ${ }^{103}$

\section{c) Weiteres}

Die Schaffung des DLT-Handelssystems bildet den Kern der Anpassungen im Finanzmarktrecht gemäss dem Vorschlag des Bundesrates. Die Einbettung des DLT-Handelssystems ins FinfraG zieht dabei eine Reihe von Anpassungen in

Vgl. Art. 6 BankV. Nach Art. 6 Abs. 2 BankV handelt nicht gewerbsmässig im Sinne des Bankengesetzes, wer dauernd mehr als 20 Publikumseinlagen entgegennimmt oder sich dafür öffentlich empfiehlt, wenn er (a) Publikumseinlagen von gesamthaft höchstens 1 Million Franken entgegennimmt; (b) kein Zinsdifferenzgeschäft betreibt; und (c) die Einlegerinnen und Einleger, bevor sie die Einlage tätigen, schriftlich oder in einer anderen Form, die den Nachweis durch Text ermöglicht, darüber informiert, dass (1) er von der FINMA nicht beaufsichtigt wird, und (2) die Einlage nicht von der Einlagensicherung erfasst wird. Dies unter anderem deshalb, weil im Vernehmlassungsverfahren das Anliegen nach einer Sandbox im Finanzmarktinfrastrukturrecht erneut aufgebracht wurde (vgl. DLT-Ergebnisbericht, 6,13$)$.

101 Vgl. DLT-Bericht, 113 f.; BBl 2020, 248.

102 BBl 2020, 248.

103 BBl 2020, $248 \mathrm{f}$. 
weiteren Erlassen nach sich. So ist das DLT-Handelssystem beispielsweise auch im Geldwäschereirecht $(\mathrm{GwG})^{104}$ und im Nationalbankgesetz $(\mathrm{NBG})^{105}$ abzubilden.

Ferner enthält die Vorlage Vorschläge für weitere Anpassungen im Finanzmarktrecht, die nicht direkt im Zusammenhang mit dem DLT-Handelssystem stehen:

- Bankengesetz: Im Bankengesetz enthält der Vorschlag zwei Elemente:

- Einerseits sind die bankinsolvenzrechtlichen Bestimmungen im Bankenrecht mit den Anpassungen im allgemeinen Insolvenzrecht abzustimmen. ${ }^{106}$ Die bankinsolvenzrechtliche Behandlung von Token und vergleichbaren kryptobasierten Vermögenswerten kann nicht losgelöst von der insolvenzrechtlichen Behandlung solcher Vermögenswerte im SchKG betrachtet werden. Die vorgeschlagene Regelung sieht entsprechend der Regelung im allgemeinen Insolvenzrecht vor, dass auch sammelverwahrte kryptobasierte Vermögenswerte aussonderbar bzw. absonderbar sind, sofern ersichtlich ist, welcher Anteil am Gemeinschaftsvermögen der Depotkundin oder dem Depotkunden zusteht. ${ }^{107}$

- Andererseits wirkt sich diese Neuregelung der Aus- bzw. Absonderung kryptobasierter Vermögenswerte im Insolvenzrecht auch auf die Bewilligungspflicht im Bankenrecht aus. Da absonderbare Vermögenswerte nicht als Publikumseinlagen gelten, würde dies im Ergebnis bedeuten, dass Personen solche kryptobasierten Vermögenswerte in unbeschränktem Umfang zur Verwahrung entgegennehmen könnten, ohne dass sie dafür über eine Bankbewilligung - oder eine andere einschlägige finanzmarktrechtliche Bewilligung - verfügen und keine aus einer solchen Bewilligung fliessenden Pflichten einhalten müssten. ${ }^{108}$ Ent-

Vgl. Art. 2 Abs. 2, Art. 12 Bst. a, Art. 17 Abs. 1 Bst. a, Art. 22a Abs. 2 Bst. a und Art. $26 a$ Abs. 1 EGwG. Die Unterstellung von DLT-Handelssystemen unter das GwG wurde in der Vernehmlassung als nachvollziehbar erachtet und mehrheitlich vollumfänglich begrüsst (vgl. DLTErgebnisbericht, 12 f.).

Art. 19 Abs. 1 und 20 Abs. 1 NBG. Die Erweiterung der Aufgaben der SNB auf DLT-Handelssysteme wurde in der Vernehmlassung nicht grundsätzlich in Frage gestellt. Verschiedentlich erfolgte der Einwand, dass es unwahrscheinlich sei, dass DLT-Handelssysteme in absehbarer Zeit systematisch bedeutsam würden und deshalb eine Anpassung des NBG auch später erfolgen könne (vgl. DLT-Ergebnisbericht, 11). Siehe oben, III.1.c).

107 Vgl. Art. 16 Ziff. $1^{\text {bis }}$ E-BankG, wonach kryptobasierte Vermögenswerte ebenfalls als Depotwerte gelten sollen, die nach Art. 37d BankG absonderbar sind.

108 Ein solcher bewilligungsfreier Raum würde erhebliche Risiken bergen. Vgl. weiterführend: BBl 2020, $268 \mathrm{f}$. 
sprechend soll der Unterstellungstatbestand nach Artikel $1 b$ Bankengesetz angepasst werden. ${ }^{109}$ Ferner sieht die DLT-Vorlage vor, dass der FINMA explizit die Kompetenz eingeräumt wird, die von einer Bank oder einer Person nach Artikel $1 b$ BankG als Depotwerte gehaltenen kryptobasierten Vermögenswerte aus Risikoerwägungen in der Höhe zu begrenzen. ${ }^{110}$

- Finanzinstitutsgesetz: Ergänzend zum DLT-Handelssystem soll im FINIG eine komplementäre Flexibilisierung für Wertpapierhäuser erfolgen. Neu soll als Wertpapierhaus auch gelten, wer den Eigenhandel und ein organsiertes Handelssystem (Art. 42 FinfraG) betreibt. Damit wird der Problematik begegnet, dass der Betrieb eines organisierten Handelssystems nach geltendem Recht eine Bewilligung als Bank, Wertpapierhaus oder Handelsplatz oder einer Anerkennung als Handelsplatz bedarf, eine solche Bewilligung jedoch spezifisch und alleine zum Betrieb eines organisierten Handelsplatzes nicht erteilt würde. ${ }^{111}$

- Finanzdienstleistungsgesetz: Die Legaldefinition der "Effekte“ findet sich sowohl im FinfraG als auch im FIDLEG. ${ }^{112}$ Aufgrund der vorgeschlagenen Anpassungen im FinfraG ist die korrespondierende Bestimmung im FIDLEG anzugleichen. ${ }^{113}$ Materiell gilt es in diesen Legaldefinitionen, die neuen Registerwertrechte (Art. 973d E-OR) abzubilden.

\section{d) Regelung vollständig dezentraler „Infrastrukturen“?}

Das DLT-Handelssystem ist in seiner Konzeption eine (zumindest teilweise) zentral organisierte Finanzmarktinfrastruktur, die spezifische Finanzmarktinfrastrukturdienstleistungen mit DLT-basierten Effekten erbringt. Das DLTHandelssystem ist damit konzeptionell vergleichbar mit den heutigen Finanzmarktinfrastrukturen, die ebenfalls zentral organisiert sind.

In der DLT-Vorlage nicht geregelt werden dagegen die vollständig dezentralen „Finanzmarktinfrastrukturen“, d.h. Infrastrukturdienstleistungen ohne unmittelbaren und klar identifizierten Betreiber. In seiner Botschaft hielt der Bun-

Die Bewilligungspflicht nach Artikel $1 b$ BankG soll entsprechend auf Tatbestände ausgeweitet werden, bei denen bestimmte kryptobasierte Vermögenswerte (in der Form von Depotwerten) entgegengenommen werden.

110 Vgl. Art. $4^{\text {sexies }}$ BankG.

111 Vgl. weiterführend: BBl 2020, $305 \mathrm{f}$.

112 Art. 2 Bst. b FinfraG; Art. 3 Bst. b FIDLEG.

113 Vgl. Art. 2 Bst. b E-FinfraG; Art. 3 Bst. b E-FIDLEG. 
desrat hierzu fest, dass er die diesbezüglichen technologischen und regulatorischen Entwicklungen genau beobachten und gegebenenfalls eine separate rechtliche Regelung der dezentralen Infrastrukturen vorschlagen werde. ${ }^{114}$

\section{Ausblick}

Ende November 2019 überwies der Bundesrat die Botschaft zum Bundesgesetz zur Anpassung des Bundesrechts an Entwicklungen der Technik verteilter elektronischer Register ans Parlament. ${ }^{115}$ Die Kommission für Wirtschaft und Abgaben (WAK) des Nationalrats beschäftigte sich ab Januar 2020 mit der Vorlage, führte mehrere Anhörungen ${ }^{116}$ durch und trat im Februar 2020 einstimmig auf die Vorlage ein. ${ }^{117}$ Der Nationalrat folgte im Juni 2020 weitgehend dem Vorschlag des Bundesrates. Im September 2020 schloss sich der Ständerat an.

Die DLT- und Blockchain-Technologien sind einerseits jung und befinden sich andererseits in einer rasanten Entwicklung, die wohl noch mehrere Jahre anhalten dürfte. Diese technologischen Entwicklungen bieten vielfältige Chancen. Die hohe Entwicklungsdynamik, gekoppelt mit der hohen Technizität der Materie, birgt aber auch Herausforderungen, beispielsweise im Hinblick auf die Schaffung neuer rechtlicher Anforderungen für DLT und Blockchain. Vor dem Hintergrund einer „ermöglichenden Rechtsordnung“, die innovationsfreundliche Rahmenbedingungen ${ }^{118}$ bereitstellen will, erscheinen dabei drei Aspekte zentral.

Erstens scheint es wichtig, dass sich künftige Rechtsnormen zu DLT und Blockchain nicht ausschliesslich auf die bereits bekannten Technologien und Anwendungen fokussieren, sondern innovationsfreundlich und zukunftsweisend ausgestaltet sind. Auch wenn beispielsweise Bitcoin bzw. die BitcoinBlockchain eine der bekanntesten Anwendungen im DLT-Kontext ist, so ist der Versuchung einer Gleichsetzung von Bitcoin und Blockchain bzw. DLT zu widerstehen.

\footnotetext{
$114 \quad$ BBl 2020, 273.

115 BBl 2020, 233 sowie BBl 2020, 329 (Gesetzesentwurf).

$116 \mathrm{Zu}$ den Anhörungsteilnehmern, vgl. die Medienmitteilung der WAK-NR vom 25. Februar 2020, abrufbar unter:

$<$ https://www.parlament.ch/press-releases/Pages/mm-wak-n-2020-02-25.aspx>.

117 Vgl. Medienmitteilung der WAK-NR vom 25. Februar 2020, abrufbar unter:

$<$ https://www.parlament.ch /press-releases/Pages/mm-wak-n-2020-02-25.aspx>.

118 Siehe oben, II.1. zu den Zielsetzungen und Grundsätzen des Schweizer Regulierungsansatzes.
} 
Zweitens ist die rechtliche Erfassung einer sich entwickelnden Materie naturgemäss herausfordernd. Die Entwicklung neuer rechtlicher Anforderungen steht in einem andauernden Spannungsfeld zwischen Rechtssicherheit und notwendiger Flexibilität. Mit einer prinzipienbasierten und grundsätzlich technologieneutralen Gestaltung sowie gezielten Delegationskompetenzen lässt sich die notwendige rechtliche bzw. regulatorische Flexibilität schaffen.

Die Schweiz gehört heute im DLT-/Blockchain-Bereich zu den international führenden Ländern. Mit den vorgeschlagenen, punktuellen Anpassungen sollen die Voraussetzungen weiter verbessert werden, damit sich die Schweiz als ein führender, innovativer und nachhaltiger Standort für DLT- und Blockchain-Unternehmen weiterentwickeln kann. In diesem Sinne beinhaltet die Vorlage eine Chance für die Schweiz, ihre führende Position beizubehalten und weiter auszubauen.

\section{Materialien}

Eidgenössische Finanzmarktaufsicht FINMA, FINMA-Aufsichtsmitteilung 04/2017, Aufsichtsrechtliche Behandlung von Initial Coin Offerings, vom 29. September 2017. Kann abgerufen werden unter $<$ www.finma.ch $>>$ Dokumentation $>$ FINMA-Aufsichtsmitteilungen.

Eidgenössische Finanzmarktaufsicht FINMA, Wegleitung für Unterstellungsanfragen betreffend Initial Coin Offerings (ICOs), Ausgabe vom 16. Februar 2018. Kann abgerufen werden unter $<$ www.finma.ch $>>$ Bewilligung $>$ Fintech.

Vernehmlassung zum Bundesgesetz zur Anpassung des Bundesrechts an Entwicklungen der Technik verteilter elektronischer Register - Ergebnisbericht, abrufbar unter $<$ https://www. admin.ch/gov/de/start/dokumentation/medienmitteilungen.msgid-77252.html> (zit. DLT-Ergebnisbericht).

Swisscom FinTech Startup-Infografik, abrufbar unter $<$ https://www.swisscom.ch/de/business /enterprise/downloads/banking/monthly-fintech-startup-market-map.html>.

Blockchain Taskforce, Positionspapier zur rechtlichen Einordnung von ICOs, April 2018. Kann abgerufen werden unter $<$ https://blockchainfederation.ch/downloads/>.

Bericht des Bundesrates vom 25. Juni 2014 zu virtuellen Währungen in Beantwortung der Postulate Schwaab (13.3687) und Weibel (13.4070), abrufbar unter <www.parlament.ch> $>$ Ratsbetrieb > Suche Curia Vista > Geschäfts-Nr. 13.3687.

Botschaft und Entwurf des Bundesrates vom 27. November 2019 über das Bundesgesetz zur Anpassung des Bundesrechts an Entwicklungen der Technik verteilter elektronischer Register, BBl 2020, 233 ff. (zit. DLT-Vorlage). 
Bericht des Bundesrates vom 18. Dezember 2019, Rechtliche Grundlagen für Distributed Ledger-Technologie und Blockchain in der Schweiz, abrufbar unter $<$ https://www.admin.ch/gov/de/start/dokumentation/medienmitteilungen.msgid-73398.html $>$ (zit. DLT-Bericht).

\section{Literatur}

BÄRTSCHI HARALD/MEISSER CHRISTIAN, Virtuelle Währungen aus finanzmarkt- und zivilrechtlicher Sicht. in: Weber/Thouvenin (Hrsg.), Rechtliche Herausforderungen durch webbasierte und mobile Zahlungssysteme. Zürich 2015, $115 \mathrm{ff}$.

ECKERT Martin, Digitale Daten als Wirtschaftsgut: digitale Daten als Sache, SJZ 2016, $245 \mathrm{ff}$.

EGGEN MIRJAM, Verträge über digitale Währungen: Eine privatrechtliche Qualifikation von Rechtsgeschäften in oder mit digitalen Währungen, Jusletter, 4. Dezember 2017 (zit. EGGEN, Verträge über digitale Währungen).

EGGEN MirJam, Was ist ein Token?, AJP 2018, 558 ff. (zit. EGGEN, Was ist ein Token?).

ESSEBIER JANA/Bourgeois JANIQUE, Die Regulierung von ICOs, AJP 2018, 568 ff. (zit. EsSEBIER/ BOURGEOIS).

FRÖHLICH-BlEULER GIANNI, Eigentum an Daten?, Jusletter, 6. März 2017.

Gless Sabine/ Kugler Peter/Stagno Dario, Was ist Geld? Und warum schützt man es?, recht 2015, $82 \mathrm{ff}$.

Gobat SÉBASTIEn, Les monnaies virtuelles à l'épreuve de la LP: Questions choisies à l'exemple du bitcoin, AJP 2016, 1095 ff.

HAUSER-SPÜHLER GABRIELA/MEISSER LUZIUS, Eigenschaften der Kryptowährung Bitcoin, digma 2018/1, 6 ff.

Hess Martin/SPielmann Patrick, Cryptocurrencies, Blockchain, Handelsplätze \& Co. - Digitalisierte Werte unter Schweizer Recht, in: Reutter/Werlen (Hrsg.), Kapitalmarkt Recht und Transaktionen XII, Zürich 2017, 145 ff.

Hrubesch-Millauer Stephanie/Graham-Siegenthaler Barbara/Roberto Vito, Sachenrecht, 5. A., Bern 2007.

HÜRLIMANN DANIEl/ZeCh HerberT, Rechte an Daten, sui-generis 2016, 89 ff.

HÜRLIMANN-KaUP BETtinA, Zahlung mit Bitcoins: Zahlung mit Sachen?, in: Emmenegger (Hrsg.), Zahlungsverkehr - Beiträge zur Schweizerischen Bankrechtstagung 2018, Basel 2018, $139 \mathrm{ff}$.

Kuhn Hans /Stengel Cornelia/Meisser Luzius /Weber Rolf H., Wertrechte als Rechtsrahmen für die Token-Wirtschaft, Jusletter IT, 23. Mai 2019.

KuHN HANS, Art. 965 ff. OR, in: Amstutz et al. (Hrsg.), Handkommentar zum Schweizer Privatrecht, 3. A., Zürich 2016.

MAURENBRECHER BENEDIKT/MEIER URS, Insolvenzrechtlicher Schutz der Nutzer virtueller Währungen, Jusletter, 4. Dezember 2017.

Meier-Hayoz ARThur/von der CRONe Hans CASPAR, Wertpapierrecht, 3. A., Bern 2018. 
Meisser Christian/Meisser Luzius/Kogens Ronald, Verfügungsmacht und Verfügungsrecht an Bitcoins im Konkurs, Jusletter IT, 24. Mai 2018.

MÜller LuKas/Reutlinger Milena/Kaiser Philippe J.A., Entwicklungen in der Regulierung von virtuellen Währungen in der Schweiz und der Europäischen Union, EuZ 2018, 80 ff.

OfTINGER KARL/BÄr ROLF, Das Fahrnispfand Art. 884-918 ZGB. Zürcher Kommentar, 3. A., Zürich 1981.

PILLER FrançOIS, Virtuelle Währungen - Reale Rechtsprobleme?, AJP 2017, 1426 ff.

Rey HeInZ, Die Grundlagen des Sachenrechts und das Eigentum, 3. A., Bern 2007.

SCHMID JÖRG/HÜRLIMANN-KAUP BETTINA, Sachenrecht, 5. A., Zürich 2017.

SCHÖNKNECHT FloRIAn, Der Einlagebegriff nach Bankengesetz, GesKR 2016, $300 \mathrm{ff}$.

von der Crone Hans CASPar/Kessler Franz J./Angstmann LuCA, Token in der Blockchain privatrechtliche Aspekte der Distributed Ledger Technologie, SJZ 2018, $337 \mathrm{ff}$.

WEBER LAURENCE/TAKACS ALEXANDRE, Le bitcoin : ce qu'il faut savoir sur le plan juridique, Plädoyer 2018/2, $37 \mathrm{ff}$.

WEBER ROLF H., Überblick über die rechtlichen Rahmenbedingungen für webbasierte und mobile Zahlungssysteme, in: Weber/Thouvenin (Hrsg.), Rechtliche Herausforderungen durch webbasierte und mobile Zahlungssysteme, Zürich 2015, 5 ff.

Weber Rolf H./Thouvenin Florent, Dateneigentum und Datenzugangsrechte - Bausteine der Informationsgesellschaft?, ZSR 2018, 43 ff. 


\title{
Intercreditor-Verhältnisse und -Verträge
}

\author{
Jürg Frick
}

\section{Inhalt}

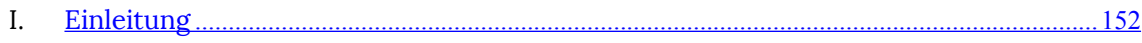

II. Ausgangslage ……………………………………………………………….....153

1. Finanzierungsinstrumente und Finanzierungsmärkte .............................................153

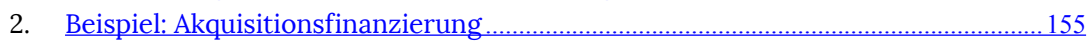

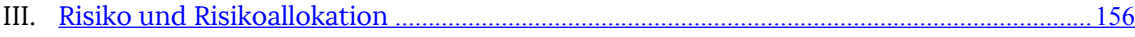

1. $\quad$ Risiken verschiedener Finanzierungsinstrumente …………………………………....156

2. Relevanz der Risikoallokation............................................................................159

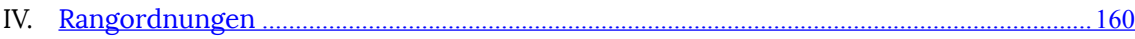

1. Gesetzliche Rangordnungen ………………………………………………………....160

a) Gesellschaftsrechtliche Rangordnung............................................................ 160

b) Konkursrechtliche Rangordnung...............................................................162

aa) Pfandgesicherte Forderungen (Art. 219 Abs. 1-3 SchKG) ........................... 162

bb) Ungesicherte Forderungen (Art. 219 Abs. 4 SchKG) …………………….....162

c) Sachenrechtliche Rangordnung ............................................................163

2. Richterrechtliche Rangordnung ……………………………………………………..163

3. Strukturelle Rangordnung ……………………………………………………………. 165

a) Zeitliche Reihenfolge ……………………………………………………..... 165

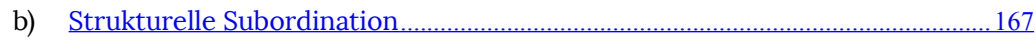

4. Vertragliche Rangordnung...………………………………………………………... 168

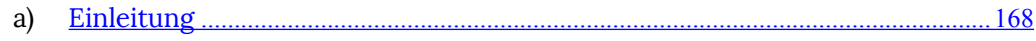

b) Arten der vertraglichen Rangordnung.………………………………….....169

aa) Nachrangvereinbarung ........................................................................169

aаa) Parteien ………………………………………………………... 169

bbb) Rechtswirkung...……………………………………………………...170

bb) Einfache Rangrücktrittserklärung........................................................172

aaa) Parteien ....………………………………………………………....172

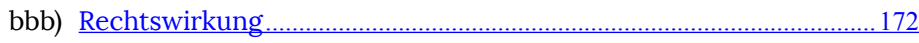

cc) Rangrücktritt im Sinne von Art. 725 Abs. 2 OR ……………………………...173

aаa) Parteien ...………………………………………………………….... 173

bbb) Rechtswirkung ...…………………………………………………...174

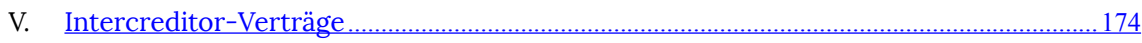

1. Vertragsstrukturen …………………………………………………………... 174

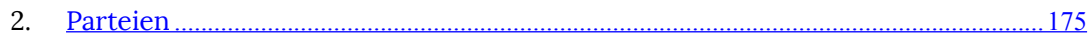

3. Regelungsgegenstände ………………………………………………………………176

a) Rangordnung ………………………………………………………………...176 
b) Zahlungen an nachrangige Gläubiger .............................................................. 176

c) Zusätzliche Sicherheiten zugunsten nachrangiger Gläubiger ............................177

d) Suspendierung von Rechten nachrangiger Gläubiger ........................................177

e) Verwertung von Sicherheiten ........................................................................... 178

f) Verteilung des Verwertungserlöses …………………………………....... 179

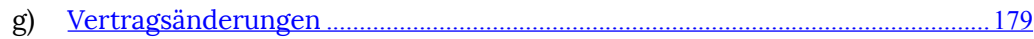

h) Vorrangstellung des Intercreditor-Vertrags (Override) .....................................180

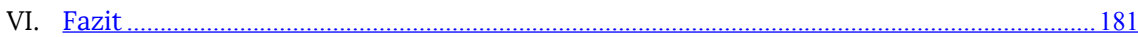

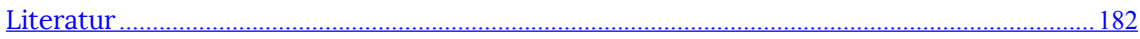

Loan Market Association (LMA) Vertragsvorlagen ……........................................................ 183

\section{Einleitung}

Intercreditor-Verhältnisse bezeichnen Rechtsverhältnisse zwischen Gläubigern ein und desselben Schuldners. Sie entstehen, wenn sich ein Unternehmen gleichzeitig bei mehreren Kapitalgebern finanziert, sei es unter identischen oder verschiedenartigen Finanzierungsinstrumenten. Das Risiko, das einzelne Gläubiger oder Gläubigergruppen tragen, hängt von der Rangfolge ab, nach der sie befriedigt werden.

Solange ein Unternehmen aufrechtstehend ist, ergibt sich die Rangfolge der Forderungen aus der zeitlichen Abfolge, nach der sie erfüllt werden. Wer sein Geld früher zurückerhält, trägt ein geringeres Risiko und kann günstigere Finanzierungskonditionen offerieren. Sollte das Unternehmen in Konkurs fallen, dann werden nach Schweizer Konkursrecht grundsätzlich sämtliche Forderungen gegenüber dem Schuldner mit Konkurseröffnung gleichzeitig fällig. ${ }^{1}$ Die Rangordnung zeigt sich dann darin, welche Forderungen vorrangig aus dem Konkurserlös befriedigt werden. Sollte die gesetzlich vorgegebene Rangordnung den Interessen der verschiedenen Gläubiger oder Gläubigergruppen nicht gerecht werden, so kann diese mit strukturellen oder vertraglichen Mitteln weiter ausgestaltet werden.

Ziel dieses Beitrags ist es, Intercreditor-Verhältnisse darzustellen und zu zeigen, mit welchen gesetzlichen, richterrechtlichen, strukturellen oder vertrag-

1 Nach Art. 208 Abs. 1 SchKG bewirkt die Konkurseröffnung gegenüber der Konkursmasse die Fälligkeit sämtlicher Schuldverpflichtungen des Schuldners mit Ausnahme derjenigen, die durch Grundstücke pfandrechtlich gedeckt sind. 
lichen Mitteln, inkl. Intercreditor-Verträgen, das Verhältnis zwischen verschiedenen Gläubigern oder Gläubigergruppen und deren Rangordnung untereinander gestaltet werden können.

Eine abschliessende Darstellung wird nicht möglich sein.

\section{Ausgangslage}

\section{Finanzierungsinstrumente und Finanzierungsmärkte}

Bei grösseren Unternehmen entspricht es der Regel und weniger der Ausnahme, dass sie sich bei mehreren Kapitalgebern finanzieren. Finanzierungszweck kann etwa die Finanzierung einer Unternehmensübernahme sein, die Refinanzierung bestehender Finanzverbindlichkeiten oder eine Betriebsmittelfinanzierung.

Die Finanzierungsinstrumente lassen sich in die zwei Hauptgruppen des Eigen- und Fremdkapitals unterscheiden. Eigenkapital steht einem Unternehmen auf unbeschränkte Dauer zur Verfügung und vermittelt einem Eigenkapitalinvestor keinen Rückerstattungsanspruch. Der Investor wird Gesellschafter des finanzierten Unternehmens. Neben den gesellschaftsrechtlichen Rechten, inkl. Dividendenanspruch, die ein Investor aufgrund seiner Beteiligung erhält, besteht das Interesse - insbesondere eines Finanzinvestors - darin, an einer Wertsteigerung des Unternehmens zu partizipieren und über einen späteren Verkauf der Beteiligung einen Kapitalgewinn zu erzielen. ${ }^{2}$ Umgekehrt dient Eigenkapital dem Unternehmen als Risikokapital, das - sollte das Unternehmen in finanzielle Schwierigkeiten geraten - Verluste aus der Geschäftstätigkeit deckt und einen Konkurs abzuwenden hilft. $^{3}$

Möchte ein Unternehmen bzw. möchten die Eigentümer eines Unternehmens mit einer Finanzierung einen Hebel- oder Leverage-Effekt erzielen und bei positivem Geschäftsverlauf die Rendite auf dem eingesetzten Eigenkapital

FRICK, $6 \mathrm{f}$.

FRICK, 12 ff. 
(Return on Equity, ROE) erhöhen, dann ist eine Finanzierung mit Fremdkapital angezeigt. ${ }^{4}$ Für Fremdkapitalfinanzierungen stehen einem Unternehmen wiederum verschiede Finanzierungsinstrumente und -Märkte zur Verfügung.

Ein kapitalsuchendes Unternehmen kann auf dem Kapitalmarkt Anleihen ausgeben. Je nach Bonität des Unternehmens wird zwischen Corporate Bonds und Hochrisikoanleihen (High Yield Bonds) unterschieden. Möchte ein Unternehmen den Kapitalmarkt etwa aufgrund der damit einhergehenden Transparenzpflichten oder der relativen Starrheit von Anleihen vermeiden, dann kann es auf dem Bankenmarkt einen Kredit aufnehmen. Ist der Kapitalbedarf des Unternehmens überschaubar, dann genügt allenfalls ein bilateral von der Hausbank des Unternehmens gewährtes Darlehen. Sollte der Kapitalbedarf grösser sein, so kann das Unternehmen bei einem Bankenkonsortium einen syndizierten Kredit aufnehmen. Neben den Banken, die traditionell den Kreditmarkt bedienen, treten heutzutage vermehrt weitere Parteien als Kreditgeber auf, wie bspw. Versicherungsgesellschaften, Fonds, institutionelle Anleger, Gemeinwesen oder selbst Kleinanleger im Rahmen von sog. Schwarmfinanzierungen (Crowd Lending).

Jedes der verfügbaren Finanzierungsinstrumente hat aus Sicht eines Unternehmens seine Eigenheiten bzw. Vor- und Nachteile. Diese Eigenheiten sind häufig durch die Interessen und Möglichkeiten der dahinterstehenden Kapitalgeber bedingt. Investoren, die über den Kapitalmarkt Anleihen kaufen, sind weniger am Unternehmen bzw. am operativen Geschäft des Unternehmens interessiert, sondern vielmehr daran, ihr Geld für eine längere Zeit zu einem bestimmten Zins fest anzulegen. Banken sind dagegen regelmässig an einer nachhaltigen Geschäftsbeziehung zum Unternehmen interessiert, bevorzugen aber aufgrund ihrer Eigenmittelunterlegungspflichten sog. vorrangige (senior) Finanzierungen, die allenfalls besichert oder von Dritten garantiert werden. Dagegen sind Fonds und insbesondere sog. Mezzanine Fonds häufig bereit, auch nachrangige (junior) Finanzierungen zu gewähren; im Gegenzug erwarten sie aber eine höhere Risikoprämie, d.h. einen höheren Zins, allenfalls verbunden mit Wandel- oder Optionsrechten (Equity Kicker).

4 DIEM/JAHN, \$1 N 14 ff.: Der Leverage-Effekt beruht darauf, dass die Rendite des eingesetzten Eigenkapitals mit steigender Verschuldung zunimmt, solange die Gesamtkapitalrendite (d.h. die Rendite auf dem insgesamt im Unternehmen eingesetzten Eigen- und Fremdkapital) höher ist als der Fremdkapitalzins. Um diesen Hebeleffekt zu nutzen, finanzieren die Übernehmer eines Unternehmens den Kaufpreis mit möglichst viel Fremd- und mit möglichst wenig Eigenkapital. Der Nachteil dieses Finanzierungskonzepts liegt darin, dass durch den erhöhten Fremdkapitaleinsatz nicht nur die Eigenkapitalrendite, sondern auch das Konkursrisiko des übernehmenden Unternehmens steigt. 
Gemeinsam ist allen Fremdkapitalfinanzierungen, dass sie den Kapitalgebern eine Forderung bzw. einen Rückerstattungsanspruch gegenüber dem finanzierten Unternehmen vermitteln. Durch die Kapitalhingabe werden die Kapitalgeber zu Gläubigern des Unternehmens und setzen sich in der Folge dem Gegenpartei- oder Ausfallrisiko des Unternehmens aus.

\section{Beispiel: Akquisitionsfinanzierung}

Als Beispiel einer Finanzierung, bei der sich ein Unternehmen über verschiedene Finanzierungsinstrumente bei verschiedenen Kapitalgebern finanziert, eignet sich eine Akquisitionsfinanzierung. Eine solche Finanzierung lässt sich graphisch wie folgt darstellen:

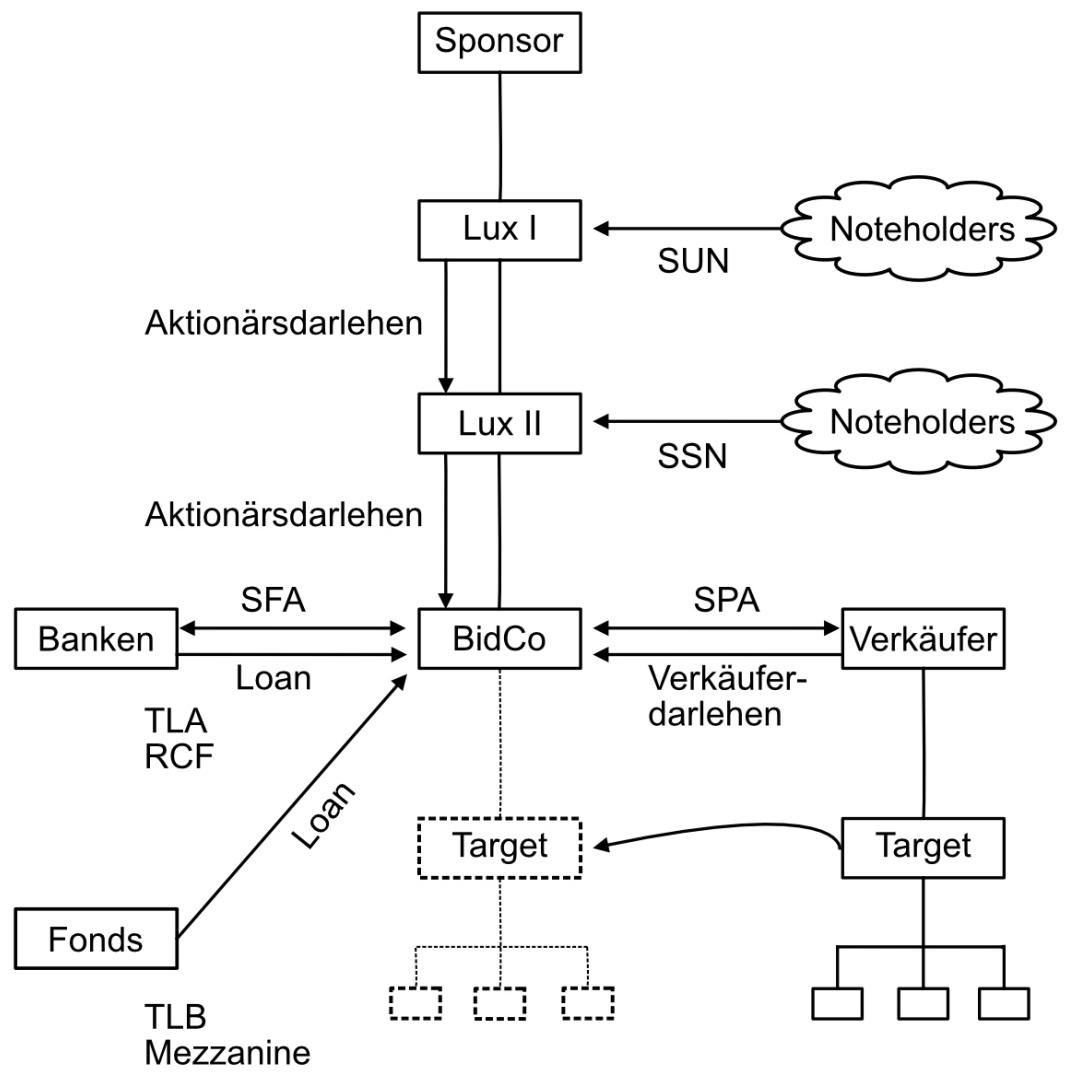


Im Zentrum einer Akquisitionsfinanzierung bzw. eines Unternehmenskaufs steht die BidCo, d.h. eine Gesellschaft, die zum Zweck des Unternehmenserwerbs aufgesetzt wird. Diese schliesst mit dem Verkäufer (Seller) der Zielgesellschaft (Target) einen Aktienkaufvertrag (Share Purchase Agreement, SPA) ab. Daraus wird die BidCo als Käuferin (Purchaser) gegenüber dem Verkäufer verpflichtet, den Kaufpreis für die Aktien an der Zielgesellschaft zu bezahlen.

Um den Kaufpreis zu bezahlen, kapitalisiert der Sponsor, d.h. die Partei, welche hinter BidCo steht, diese bspw. wie folgt:

(1) über seine Beteiligungen an den Emissionsgesellschaften Lux I, Lux II und BidCo bringt er Eigenkapital in BidCo ein;

(2) die Lux I emittiert über den Kapitalmarkt eine unbesicherte Anleihe (Senior Unsecured Note, SUN) und gibt den Emissionserlös über (nachrangige) Aktionärsdarlehen an BidCo weiter;

(3) die Lux II emittiert über den Kapitalmarkt eine besicherte Anleihe (Senior Secured Note, SSN) und gibt den Emissionserlös ebenfalls über ein (nachrangiges) Aktionärsdarlehen an BidCo weiter;

(4) BidCo schliesst mit einem Bankenkonsortium einen Kreditrahmenvertrag (Senior Facilities Agreement, SFA) ab, unter welchem sie ein oder mehrere langfristige, vorrangige, amortisierende Darlehen (Term Loan A, TLA), ein oder mehrere langfristige, vorrangige, nicht-amortisierende Darlehen (Term Loan B, TLB) sowie unter einer Betriebsmittelkreditlinie (Revolving Credit Facility, RCF) verschiedene kurzfristige, vorrangige Darlehen beziehen kann;

(5) BidCo kann zudem bei einem Fonds ein sog. Mezzanine Darlehen aufnehmen, d.h. ein nachrangiges Darlehen, das allenfalls mit Wandel- oder Optionsrechten verbunden ist; und

(6) schliesslich kann sich BidCo vom Verkäufer der Zielgesellschaft ein sog. Verkäuferdarlehen (Vendor Loan) gewähren lassen.

\section{Risiko und Risikoallokation}

\section{Risiken verschiedener Finanzierungsinstrumente}

Obwohl alle Fremdkapitalgläubiger eine eigenständige Forderung gegenüber dem finanzierten Unternehmen erwerben, sind nicht alle demselben Gegenpartei- oder Ausfallrisiko des Unternehmens ausgesetzt. Das Risiko, das ein Gläubiger trägt, hängt von der Ausgestaltung und den Bedingungen (Terms and Conditions) des jeweiligen Fremdkapitalinstruments ab. 
Wesentliche Elemente sind bspw.:

(1) Laufzeit (Term/Tenor): Je kürzer die Laufzeit einer Finanzierung und je schneller ein Gläubiger sein Geld zurückerhält, desto geringer ist sein Gegenpartei- oder Ausfallrisiko. Je länger es bis zur Rückzahlung dauert, desto grösser ist die Unabwägbarkeit des wirtschaftlichen Gedeihens des schuldnerischen Unternehmens und desto grösser wird die Gefahr, dass das Unternehmen in finanzielle Schwierigkeiten und letztlich in die Insolvenz geraten könnte.

(2) Rang (senior vs. junior): Der Rang eines Fremdkapitalinstruments bezeichnet die Reihenfolge, in welcher die Forderung aus dem Instrument im Konkurs des schuldnerischen Unternehmens befriedigt wird. Ein Instrument ist gegenüber einem anderen vorrangig (senior), wenn die Forderung daraus vor der nachrangigen Forderung (junior) befriedigt wird. Umgekehrt bedeutet das, dass nachrangige Forderungen erst dann befriedigt werden, wenn sämtliche ihnen gegenüber vorrangigen Forderungen befriedigt sind (Art. 220 Abs. 2 SchKG). ${ }^{5}$ Forderungen, die gleichrangig (pari passu) sind, werden in ihrem Verhältnis zueinander gleichmässig befriedigt (Art. 220 Abs. 1 SchKG). Je höher im Rang ein Finanzierungsinstrument steht, d.h. je früher es im Konkurs eines Unternehmens befriedigt wird, desto geringer ist das damit einhergehende Gegenpartei- oder Ausfallrisiko.

(3) Besichert/garantiert vs. unbesichert/nicht garantiert (secured/guaranteed vs. unsecured/non-guaranteed): Um das Gegenpartei- oder Ausfallrisiko abzufedern, das mit einem Fremdkapitalinstrument einhergeht, können sich Fremdkapitalgläubiger absichern lassen. Bei den Besicherungen wird zwischen Personal- und Realsicherheiten unterschieden. Bei Personalsicherheiten erhalten die Fremdkapitalgläubiger einen obligatorischen Ersatz- oder Sicherungsanspruch gegenüber einem Dritten. ${ }^{6}$ Dieser Dritte kann seine Verpflichtung in Form einer Garantie im Sinne von Art. 111 OR, einer Bürgschaft gemäss Art. 492 ff. OR oder einer kumulativen Schuldübernahme eingehen.

Fällt die Partei, die eine Personalsicherheit gegeben hat, in Konkurs, so werden die Forderungen der Gläubiger dieser garantierten Forderungen in der dritten Konkursklasse der konkursiten Partei kolloziert. Garantien, Bürgschaften oder kumulative Schuldübernahmen bewirken keinen Vorrang der garantierten Forderung gegenüber anderen Forderungen gegen

\footnotetext{
5 GlanZmann, Rangrücktritt, 6 ff.; BÖsCh, 56 ff.; KäLIN, 52 ff.; RHODE, 83; BSK OR I-MAURENBRECHER/SCHÄRER, Art. 312 N 15 ff.

6 MAURENBRECHER/FrICK, $61 \mathrm{ff}$.
} 
die konkursite Partei.

Anders als bei Personalsicherheiten erhalten die begünstigten Parteien einer Realsicherheit keinen obligatorischen Anspruch gegenüber einem Dritten, sondern eine dingliche Berechtigung an einem Haftungsobjekt. ${ }^{7}$ Dieses Haftungsobjekt bzw. der vom Sicherungsrecht beschlagene Vermögenswert kann dem Vermögen des finanzierten Unternehmens oder eines Dritten entstammen. Den Fremdkapitalgläubigern kann ein beschränktes dingliches Recht in Form eines Pfandrechts eingeräumt werden oder es kann das dingliche Vollrecht, d.h. das Eigentum an einem Vermögensgegenstand, verbunden mit einer Sicherungsabrede auf die Fremdkapitalgläubiger oder deren Sicherheitenagenten (Security Agent) übertragen werden.

Gemäss Art. 219 Abs. 1 SchKG werden pfandgesicherte Forderungen aus dem Pfandverwertungserlös vorweg bezahlt. Pfandgesicherte Forderungen sind somit im Konkurs des Pfandgebers privilegiert und lediglich der nach der Verwertung ungedeckt verbleibende Betrag einer pfandgesicherten Forderung wird zusammen mit allen anderen unbesicherten, nicht privilegierten Forderungen gegenüber der konkursiten Partei in der dritten Konkursklasse kolloziert.

(4) Wandlung (Conversion), Abschreibung (Write-down): Bestimmte Finanzierungsinstrumente können mit einem Wandlungsrecht oder, bei Eintritt bestimmter Ereignisse, mit einer Wandlungspflicht verbunden sein. Dabei wird die Rückerstattungsforderung aus dem Fremdkapitalinstrument in Beteiligungsrechte am finanzierten Unternehmen gewandelt. ${ }^{8}$ Der Fremdkapitalgläubiger wird dadurch zum (Mit-)Eigentümer bzw., im Fall einer Aktiengesellschaft, Aktionär des Unternehmens.

Die Pflichtwandlung erlaubt einem finanziell angeschlagenen Unternehmen, Gläubigerforderungen durch Wandlung von Fremd- in Eigenkapital abzuwenden und Risikokapital aufzubauen. Das Risiko, das der Inhaber eines Pflichtwandelinstruments trägt, besteht nicht nur darin, dass er seine Forderung verlieren kann und dafür verlusttragende Beteiligungstitel erhält, sondern auch darin, dass für diese Beteiligungstitel unter Umständen kein liquider Markt besteht und er die Titel daher nicht oder nicht einfach veräussern kann.

Wandlungsinstrumente sind nicht zu verwechseln mit Instrumenten, die unter bestimmten Bedingungen einen Forderungsverzicht nach sich zie-

MAURENBRECHER/FRICK, 62.

REUTTER/WEBER, 129; BSK OR I-MAURENBRECHER/SCHÄRER, Art. 312 N 25 ff. 
hen (Write-down). ${ }^{9}$ Solche Instrumente tragen das Risiko des sofortigen Teil- oder Totalverlusts durch Teilabschreibung oder Abschreibung auf null in sich.

(5) Bilaterale Finanzierungsinstrumente vs. Finanzierungsinstrumente, die von mehreren Gläubigern gewährt werden: Bei rein bilateralen Finanzierungen steht einem Unternehmen unter einem Finanzierungsinstrument ein einzelner Gläubiger gegenüber. Wird eine Finanzierung jedoch von mehreren Fremdkapitalgebern zusammen getätigt, sei es unter einem einzelnen Finanzierungsinstrument oder unter verschiedenartigen Finanzierungsinstrumenten, dann stehen dem Unternehmen mehrere Gläubiger oder Gläubigergruppen gegenüber. Dies kann sich auf das Risiko negativ auswirken, das einem Gläubiger aus einem Finanzierungsinstrument erwächst, weil Finanzierungen durch mehrere Parteien jeweils mit einem sog. Collective Action-Risiko einhergehen. ${ }^{10}$

Dieses Risiko besteht darin, dass jeder einzelne dazu neigen kann, sich opportunistisch zu verhalten und seinen Aufwand und seine Transaktionskosten möglichst gering zu halten bzw. zu externalisieren, d.h. von einem Dritte tragen zu lassen. ${ }^{11}$ Streng rationales Verhalten kann so bspw. dazu verleiten, den eigenen Überwachungsaufwand zu reduzieren und darauf zu vertrauen, dass das finanzierte Unternehmen von einem andern Fremdkapitalgeber überwacht wird. Wenn sich sämtliche Fremdkapitalgeber opportunistisch verhalten, dann besteht die Gefahr, dass letztlich niemand das Unternehmen überwacht. Dies würde letztlich sämtlichen Fremdkapitalgläubigern zum Nachteil gereichen (Prisoner's Dilemma). ${ }^{12}$

\section{Relevanz der Risikoallokation}

Je höher das Risiko, das einem Fremdkapitalgläubiger aus einem Finanzierungsinstrument erwächst, desto höher ist die Risikoprämie, mit der er sich dieses Risiko abgelten lässt, bzw. desto teurer wird in der Regel dieses Finanzierungsinstrument für das kapitalsuchende Unternehmen (Pecking Order-Hypothese). ${ }^{13}$ Umgekehrt sollten risikoärmere Finanzierungsinstrumente zu günstigeren Konditionen platziert werden können.

\footnotetext{
REUTTER/WEBER, 133.

BAIRD/GERTNER/PICKER, $188 \mathrm{ff}$.

FRICK, 46 ff. m.w.H.

BAIRD/GERTNER/PICKER, $191 \mathrm{ff}$.

MYERS, $575 \mathrm{ff}$.
} 
Ist ein Finanzierungsinstrument eines Unternehmens mit einem höheren Ausfallrisiko verbunden als ein anderes Instrument desselben Schuldners und lassen sich die Gläubiger des risikoreicheren Instruments dieses Risiko mit einer höheren Risikoprämie abgelten, dann sind die Gläubiger des weniger risikoreichen Instruments interessiert, dass diese Risikoallokation während der Laufzeit der verschiedenen Instrumente nicht zu Ungunsten des weniger risikoreichen Instruments verändert wird.

\section{Rangordnungen}

Aufgrund der unterschiedlichen Risiken, die mit einem Fremdkapitalinstrument einhergehen, und der unterschiedlichen Risikokompensation, die sich Kapitalgeber dafür einräumen lassen, rechtfertigt es sich, eine Rangfolge vorzusehen, entlang derer die Forderungen dieser Kapitalgeber im Fall des Konkurses des finanzierten Unternehmens befriedigt werden.

Die Rangordnung beruht vorab auf Gesetzes- und Richterrecht. Wird sie dem Einzelfall nicht gerecht, dann kann die Rangordnung durch strukturelle Massnahmen oder Parteiabrede weiter abgestuft und strukturiert werden.

\section{Gesetzliche Rangordnungen}

\section{a) Gesellschaftsrechtliche Rangordnung}

Für eine erste Rangordnung sorgt das dem Schweizer Gesellschaftsrecht immanente Kapitalschutzprinzip. Dieses besagt, dass Forderungen der Gläubiger einer Gesellschaft vor gewissen Forderungen der Gesellschafter zu befriedigen sind. ${ }^{14}$ Seinen aktienrechtlichen Niederschlag hat dieses Prinzip im Verbot der Einlagerückgewähr nach Art. 680 Abs. 2 OR und dem Verbot der verdeckten Gewinnausschüttung nach Art. 678 Abs. 1 und 2 OR gefunden.

Das Verbot der Einlagerückgewähr untersagt einem Aktionär, seine Einlage in die Gesellschaft zurückzufordern. Das Verbot erfasst neben der im Rahmen der Aktienliberierung geleisteten Kapital- oder Sacheinlage sämtliche Verträge und Transaktionen, die wirtschaftlich betrachtet der Rückerstattung einer Einlage gleichkommen. ${ }^{15}$

Das Verbot der verdeckten Gewinnausschüttung bestimmt zudem, dass Aktionäre, Mitglieder des Verwaltungsrats sowie diesen nahestehende Personen,

\footnotetext{
14 MEYER, $25 \mathrm{ff}$.

15 RUSCH, $134 \mathrm{ff}$.
} 
die ungerechtfertigt und in bösem Glauben Dividenden, Tantiemen, andere Gewinnanteile oder Bauzinse bezogen haben, zur Rückerstattung verpflichtet sind. Diese Personen sind auch zur Rückerstattung anderer Leistungen verpflichtet, soweit diese in einem offensichtlichen Missverhältnis zur Gegenleistung und zur wirtschaftlichen Lage der Gesellschaft stehen.

Die beiden Verbote, d.h. das Verbot der Einlagerückgewähr und das Verbot der verdeckten Gewinnausschüttung ergänzen sich. Während das Verbot der Einlagerückgewähr Geschäfte erfasst, welche die Kapitaleinlage betreffen, schützt das Verbot der verdeckten Gewinnausschüttung die frei ausschüttbaren Mittel vor verdeckten Entnahmen. ${ }^{16}$

Das Kapitalschutzprinzip führt unter anderem dazu, dass eine Aktiengesellschaft einer direkten oder indirekten Mutter- oder Schwestergesellschaft sog. Up-Stream- oder Cross-Stream-Leistungen, die nicht zu Marktbedingungen erbracht werden, nur unter einschränkenden Bedingungen gewähren kann und immer nur in dem Umfang, in welchem sie in einem Leistungs- oder Verwertungszeitpunkt über frei verfügbare Mittel verfügt.

Aus einem Intercreditor-Blickwinkel heisst das, dass unterschieden werden muss, ob ein Gläubiger einer Schweizer Kapitalgesellschaft eine nahestehende Person oder ein unabhängiger Dritter ist. Erbringt die Gesellschaf einer direkten oder indirekten Mutter- oder Schwestergesellschaft oder einer anderen nahestehenden Person eine Leistung, die nicht zu Marktbedingungen abgegolten wird, dann kann der Gläubiger entweder rückerstattungspflichtig werden (Art. 678 OR) oder die Leistung kann a priori nichtig sein (Art. 680 Abs. 2 $\mathrm{OR})$.

Zwar sind Leistungen, die ein Unternehmen zu ungerechtfertigten Vorzugskonditionen an nahestehende Dritte erbringt, gegenüber Leistungen, die zu Marktkonditionen erbracht werden, sei es an nahestehende Personen oder unabhängige Dritte, nicht nachrangig, sie sind aber im Umfang auf den Betrag der frei verfügbaren Mittel der Gesellschaft im Zeitpunkt der Leistungserbringung beschränkt. Sollte die Gesellschaft in diesem Zeitpunkt keine frei verfügbaren Mittel haben, dann darf diese Leistung nicht erbracht werden bzw. sie wird betragsmässig auf null reduziert. Eine solche Reduktion erfolgt zum Vorteil derjenigen Gläubiger, die Forderungen aus Leistungen haben, die gegenüber dem Schuldner zu Marktbedingungen erbracht wurden. Entsprechend kann sich auch das gesellschaftsrechtliche Kapitalschutzprinzip auf die Rangordnung unter den Gläubigern auswirken.

16 RUSCH, 135. 


\section{b) Konkursrechtliche Rangordnung}

Augenfälliger als die auf dem gesellschaftsrechtlichen Kapitalschutzprinzip basierende Rangordnung, ist die Rangordnung, die das Schweizer Konkursrecht für Gläubiger im Rahmen des Konkurses einer Schweizer Gesellschaft vorsieht.

In einem ersten Schritt bewirkt Art. 208 Abs. 1 SchKG, dass mit Konkurseröffnung grundsätzlich sämtliche Verpflichtungen einer konkursiten Gesellschaft fällig werden. Art. 219 SchKG regelt sodann, in welcher Reihenfolge die Forderungen gegenüber der konkursiten Gesellschaft befriedigt werden.

aa) Pfandgesicherte Forderungen (Art. 219 Abs. 1-3 SchKG)

Hat ein konkursites Unternehmen Pfänder zur Besicherung eigener Verpflichtungen oder Verpflichtungen Dritter bestellt, so ist der Erlös aus der Pfandverwertung gem. Art. 219 Abs. 1 SchKG vorab zur Befriedigung dieser pfandgesicherten Forderungen $\mathrm{zu}$ verwenden. Diese Regelung gilt für Grundpfandrechte, Faustpfandrechte und Grundlasten. ${ }^{17}$

Um ungerechtfertigte Pfandbegünstigung zu vermeiden, sieht Art. 285 ff. SchKG als Korrektiv vor, dass gewisse Pfandrechte, die innerhalb einer bestimmten Verdachtsperiode vor Konkurseintritt gewährt wurden, angefochten werden können (paulianische Anfechtung). ${ }^{18}$

\section{bb) Ungesicherte Forderungen (Art. 219 Abs. 4 SchKG)}

Ungesicherte Forderungen eines konkursiten Unternehmens werden nach Art. 219 Abs. 4 SchKG in drei Konkursklassen unterteilt. Die ersten beiden Konkursklassen umfassen privilegierte Forderungen.

In die erste Konkursklasse fallen gem. Art. 219 Abs. 4 SchKG unter anderem Forderungen von Arbeitnehmern aus dem Arbeitsverhältnis oder aus Sozialplänen, Ansprüche gewisser Versicherten sowie gewisse familienrechtliche Unterhalts- und Unterstützungsansprüche. ${ }^{19}$

Zur zweiten Konkursklasse gehören nach Art. 219 Abs. 4 SchKG Forderungen von Personen, deren Vermögen kraft elterlicher Gewalt dem konkursiten Unternehmen anvertraut worden war, für alles, was dasselbe ihnen in dieser

\footnotetext{
17 BSK SchKG II-LORANDI, Art. 219 N 15.

18 BSK SchKG II-STAEHELIN A., Art. 285 N 1 ff.

19 BSK SchKG II-LORANDI, Art. 219 N 129 ff.
} 
Eigenschaft schuldig geworden ist (Kinderprivileg). ${ }^{20}$ Weiter gehören in diese Konkursklasse die Beitragsforderungen nach dem Bundesgesetz über die Alters- und Hinterlassenenversicherung (AHVG), dem Bundesgesetz über die Invalidenversicherung (IVG), dem Bundesgesetz über die Unfallversicherung (UVG), dem Erwerbsersatzgesetz (EOG) und dem Arbeitslosenversicherungsgesetz (AVIG). Ebenfalls in die zweite Konkursklasse gehören Prämien- und Kostenbeteiligungsforderungen der sozialen Krankenversicherung, die Beiträge der Familienausgleichskasse und Einlagen nach Art. 37a Bankengesetz (BankG).

Schliesslich umfasst die dritte und letzte Konkursklasse „alle übrigen Forderungen", d.h. alle Forderungen, die nicht pfandgesichert sind und nicht einer privilegierten, vorrangigen Konkursklasse zugewiesen werden können.

Die Bedeutung der verschiedenen Konkursklassen ergibt sich aus Art. 220 Abs. 2 SchKG. Dieser Artikel bestimmt, dass die Gläubiger einer nachfolgenden Klasse erst dann Anspruch auf ihren Anteil am Verwertungserlös der Konkursmasse haben, wenn die Gläubiger der vorangehenden Klasse(n) vollständig befriedigt sind.

Darüber hinaus ordnet Art. 220 Abs. 1 SchKG an, dass Gläubiger, deren Forderungen derselben Konkursklasse zugehören, unter sich die gleichen Rechte haben, d.h. sie stehen sog. pari passu zueinander.

\section{c) Sachenrechtliche Rangordnung}

Im Verhältnis verschiedener rechtsgültig bestellter Pfandrechte sieht das Schweizer Sachenrecht bzw. Pfandrecht für sich genommen bestimmte Prioritäten und Rangordnungen vor. ${ }^{21}$ Auf diese kann im Rahmen dieses Beitrags nicht weiter eingegangen werden.

\section{Richterrechtliche Rangordnung}

Das Bundesgericht setzt sich in seinem Entscheid vom 2. März 2006 mit der Frage auseinander, ob Aktionärsdarlehen unter bestimmten Umständen

20 BSK SchKG II-LORANDi, Art. 219 N 255 ff.; KREN KoSTKIEWICZ, 323.

21 Bspw. Art. 817 ZGB, wonach der Erlös aus dem Verkauf eines Grundstücks unter den Pfandgläubigern nach ihrem Rang verteilt wird. Oder Art. 893 Abs. 1 ZGB betr. Faustpfandrechte, wonach Gläubiger nach ihrem Rang befriedigt werden, wenn mehrere Pfandrechte auf der gleichen Sache haften. Art. 893 Abs. 2 ZGB bestimmt sodann, dass sich der Rang der Pfandrechte nach dem Zeitpunkt ihrer Errichtung bemisst. 
in Eigenkapital umzuqualifizieren seien. ${ }^{22}$ Es bezieht sich dabei auf CHRISTOPH VON GREYERZ, der in Anlehnung an die deutsche Lehre postuliert, ein Darlehen sei im Sinne eines kapitalersetzenden Darlehens in eine Kapitaleinlage umzuwandeln, wenn entweder der Drittmanns- oder der Sanierungstest nicht erfüllt werden könne. ${ }^{23}$

Der Drittmannstest fragt, ob nach Umfang und Ausgestaltung des Darlehens sowie Zeitpunkt der Darlehensgewährung anzunehmen ist, ein unabhängiger oder unbefangener Dritter hätte das Darlehen zu denselben Konditionen gewährt. Der Sanierungstest fragt sodann, ob das Darlehen in einem Zeitpunkt gewährt wurde, in welchem das finanzierte Unternehmen bereits unterkapitalisiert war und nur noch die Leistung einer Kapitaleinlage sanierende Wirkung entfaltet hätte. Beide Tests wollen eine Umwandlung von Darlehen in Eigenkapital nur dann vorsehen, wenn die Gesellschaft im Zeitpunkt der Darlehensgewährung unterkapitalisiert war, weil auch nur dann ein Darlehen zu marktüblichen Bedingungen nicht mehr erhältlich gewesen wäre. ${ }^{24}$

Das Bundesgericht kommt in seinem Entscheid zum Zwischenbefund, dass ein Darlehen, das weder dem Drittmanns- noch dem Sanierungstest genüge, nicht in eine Kapitaleinlage umqualifiziert werden könne, weil eine solche Betrachtungsweise bzw. eine solche Rechtsfolge dem schweizerischen Recht fremd sei. Offen lässt es hingegen die Frage, ob solche Darlehen für nachrangig erklärt werden müssten.

Auch LUKAS GLANZMANN befürwortet die Umwandlung von Darlehen, die weder dem Drittmanns- noch dem Sanierungstest genügen; Er hält jedoch dafür, dass solche Darlehen zufolge des Grundsatzes der schonenden Rechtsausübung zwar in Risikokapital, aber nicht in Eigenkapital, sondern lediglich in nachrangiges Fremdkapital umgewandelt werden sollen. ${ }^{25}$ Wird dem Drittmanns- oder Sanierungstest keine Genüge getan, dann soll ein konkludenter Rangrücktritt angenommen werden. ${ }^{26}$ Die Umwandlung sei auf den Zeitpunkt einer Konkurseröffnung vorzunehmen und sie hätte in dem Umfang zu erfolgen, in welchem die finanzierte Gesellschaft im Zeitpunkt der Darlehensgewährung unterkapitalisiert war. Um den Zweck einer Umqualifikation nicht

Urteil des Bundesgerichts 5C.230/2005 vom 2. März 2006, mit Verweis auf vON GREYERZ, $547 \mathrm{ff}$. und weitere Autoren.

23 VON GREYERZ, 550.

24 GlanzmanN, Darlehensvertrag, $140 \mathrm{f}$.

25 GLANZMAnN, Darlehensvertrag, 144.; So auch BÖCKLI, §13 N 779 f.

26 BöCKLI, §13 N 780. 
zu vereiteln, nämlich Fremdkapital in verlustragendes Risikokapital umzuwandeln, müssten auch Sicherheiten, die der Borger zur Besicherung des Darlehens bestellt hat, aufgehoben werden. ${ }^{27}$

Sollte das Bundesgericht in Zukunft die Umqualifikation von Darlehen anerkennen, die dem Drittmanns- oder Sanierungstest nicht genügen, so wäre die rechtliche Grundlage dafür wohl in Art. 1 Abs. 2 ZGB zu finden. Diese Bestimmung erlaubt es einem Richter, echte Gesetzeslücken im Sinne eines Gesetzgebers mit einer neuen, verallgemeinerungsfähigen Regel zu füllen. ${ }^{28}$ Wie PETER BÖCKLI richtig bemerkt, ist in dieser Sache das „letzte Wort [...] nicht gesprochen“.29

\section{Strukturelle Rangordnung}

\section{a) Zeitliche Reihenfolge}

Solange ein Unternehmen aufrechtstehend ist, ergibt sich die Reihenfolge, nach welcher das Unternehmen seine Schuldverpflichtungen erfüllen muss, nach dem Fälligkeitszeitpunkt dieser Verpflichtungen. Artikel 75 OR gibt vor, dass ein Gläubiger die Erfüllung seiner Forderung grundsätzlich sogleich verlangen kann, sofern sich die Zeit der Erfüllung weder durch Vertrag noch durch die Natur des Rechtsverhältnisses bestimmt.

Bei Finanzverbindlichkeiten bildet die Laufzeit, die Rückzahlungsmechanik und die Endfälligkeit dieser Verbindlichkeiten typischerweise ein zentrales Element des Finanzierungsvertrags. Ist die Endfälligkeit nicht geregelt, so können Finanzverbindlichkeiten durch Kündigung fällig gestellt werden.

Die zeitliche Staffelung der Fälligkeit verschiedener, parallel bestehender Finanzierungsinstrumente ist ein übliches Mittel zur Gestaltung der Rangordnung unter diesen Instrumenten. Bei einer Kreditfinanzierung werden typischerweise zuerst die amortisierenden Term Loans (Term Loan A) sowie die revolvierenden Betriebsmitteldarlehen (Revolving Loans) zur Rückzahlung fällig. Anschliessend werden die nicht-amortisierenden Term Loans (Term Loan B) bedient. Nochmals nachgelagert werden Mezzanine-Finanzierungen oder High Yield Bonds zur Zahlung fällig. An letzter Stelle folgen typischerweise Aktionärsdarlehen.

\footnotetext{
27 Glanzmann, Darlehensvertrag, 145.

28 BSK ZGB I-HONSELL, Art. 1 N 34 ff.

29 BÖCKLI, §13 N 790a.
} 
Auch wenn der Schuldner seine Verpflichtung erst bei Fälligkeit erfüllen muss, so ist es ihm grundsätzlich unbenommen, die Verpflichtung bereits vor Fälligkeit freiwillig zu erfüllen. Artikel $81 \mathrm{OR}$, der die Erfüllbarkeit von Forderungen vor Fälligkeit regelt, bestimmt, dass ein Schuldner eine Verpflichtung bereits vor dem Verfalltag erfüllen kann, sofern sich aus dem Inhalt oder der Natur des Vertrags oder aus den Umständen nicht eine andere Willensmeinung der Parteien ergibt. Dies gilt auch für den Schuldner einer Finanzverbindlichkeit. Dieser kann bereits vor Fälligkeit der Verbindlichkeit zur Rückzahlung berechtigt sein, rechtlich dazu verpflichtet wird er aber erst bei Eintritt der Fälligkeit.

In Kreditverträgen ist die freiwillige vorzeitige Rückzahlung (Voluntary Prepayment) typischerweise explizit erlaubt. Erfolgt eine freiwillige vorzeitige Rückzahlung während einer Zinsperiode, so ist der Kreditnehmer vertraglich zu einer Vorfälligkeitsentschädigung (Break Costs) verpflichtet, weil die Kreditgeber auch in diesem Fall ihrerseits zur Zinszahlung auf ihre Refinanzierungskredite bis zum Ende der Zinsperiode verpflichtet bleiben. ${ }^{30}$

Freiwillig vorzeitig zurückbezahlte Darlehens- oder Kreditbeträge können in der Regel nicht neu beansprucht werden. Ausgenommen sind Darlehen unter Betriebsmittelkreditlinien (Revolving Credit Facility).

Soll dem Schuldner einer Finanzverbindlichkeit untersagt werden, diese vorzeitig zurückzubezahlen, so müssen vertraglich Sperrfristen (Non-call Period) definiert werden, während derer die freiwillige, vorzeitige Rückzahlung nicht oder nur gegen Leistung einer Strafzahlung erlaubt sein soll. ${ }^{31}$ MezzanineFinanzierungen sehen häufig eine Gebühr vor (Prepayment Fee), wenn der Kredit innerhalb eines bestimmten Zeitraums, bspw. ein oder zwei Jahre, nach seiner Auszahlung bereits wieder zurückbezahlt wird. ${ }^{32}$

Im Rahmen von Intercreditor-Verhältnissen können vertraglich sog. Zahlungsverbote (Payment Blocker) oder Zahlungsstopps definiert werden. So kann bspw. eine Zahlung an Gläubiger unter nachrangigen Finanzierungsinstru-

\footnotetext{
30 DIEM/JAHN, $\$ 13$ N 19.

31 DIEM/JAHN, §38 N 8.

32 DIEM/JAHN, $§ 38$ N 9.
} 
menten untersagt werden, wenn auf einem vorrangigen Finanzierungsinstrument ein Verzugsfall eingetreten ist, bspw. die Verletzung vorgegebener Finanzkennzahlen bzw. -richtzahlen (Financial Covenants). ${ }^{33}$

\section{b) Strukturelle Subordination}

Wie einleitend gezeigt, steht die BidCo funktional im Zentrum einer Akquisitionsfinanzierung. Auf der einen Seite schliesst sie mit dem Verkäufer der Zielgesellschaft (Target) den Aktienkaufvertrag (Share Purchase Agreement) ab und auf der anderen Seite finanziert sie sich bei Banken und weiteren Kapitalgebern, inkl. ihren Aktionären, um den Kaufpreis für die Zielgesellschaft bezahlen zu können.

Da der Zweck der BidCo einzig darin besteht, die Akquisition durchzuführen und anschliessend die Beteiligung an der Zielgesellschaft zu halten, betreibt sie im Gegensatz zur Zielgesellschaft kein operatives Geschäft. Um den Schuldendienst unter ihren Finanzverbindlichkeiten trotzdem leisten zu können, ist sie darauf angewiesen, finanzielle Mittel von der Zielgesellschaft zu erhalten.

Die Zielgesellschaft kann im Rahmen des Kapitalschutzprinzips Ausschüttungen nur im gesetzlich zulässigen Rahmen vornehmen. Artikel 675 Abs. 2 OR bestimmt, dass Dividenden nur aus dem Bilanzgewinn und aus hierfür gebildeten Reserven ausgerichtet werden dürfen. Die Zielgesellschaft ist ebenfalls gehalten, zuerst ihre eigenen Gläubiger zu befriedigen, bevor sie Mittel an ihre Aktionäre ausschütten darf.

Die sog. strukturelle Subordination ergibt sich daraus, dass eine operative Gesellschaft die Mittel, die sie erwirtschaftet, immer zuerst zur Begleichung der Forderungen ihrer eigenen Gläubiger verwenden muss, bevor sie die Mittel an ihre Aktionäre ausschütten darf, damit diese die Mittel ihrerseits zur Befriedigung ihrer Gläubiger verwenden können. Die Gläubiger der BidCo sind somit gegenüber den Gläubigern ihrer operativen Tochtergesellschaft sog. strukturell subordiniert. Die Gläubiger der Muttergesellschaft der BidCo, d.h. der Lux II, welche in unserem Beispiel die Senior Secured Note ausgab, sind gegenüber den Gläubigern der operativen Tochtergesellschaft sowie der

33 Vgl. LMA Intercreditor Agreement (Senior/Mezzanine), Definition „Mezzanine Payment Stop Event“ („Mezzanine Payment Stop Event" means [an Event of Default under the Senior Facilities Agreement (other than an Event of Default constituting a Senior Payment Default) [which is notified as a material Event of Default to the Security Agent by the Majority Senior Creditors]]/[an Event of Default under clauses [...], [...] [or] [...] of the Initial Senior Facilities Agreement or any Refinancing Equivalent].) und Clause 5.3 (Issue of Mezzanine Payment Stop Notice). 
BidCo strukturell subordiniert; und die Gläubiger der Lux I, welche die Senior Unsecured Note emittierte, sind gegenüber den Gläubigern der operativen Tochtergesellschaft, der BidCo und der Lux II subordiniert. Grundsätzlich gilt, dass die Gläubiger einer Gesellschaft gegenüber den Gläubigern ihrer direkten oder indirekten Tochtergesellschaften strukturell subordiniert sind und je mehr Gesellschaften zwischen der schuldnerischen Muttergesellschaft und deren operativen Tochtergesellschaften liegen, desto tiefer im Rang sind die Gläubiger der schuldnerischen Muttergesellschaft ordiniert.

Der strukturelle Nachrang kann auch über einen sog. Debt Push-up herbeigeführt werden. ${ }^{34}$ Dabei übernimmt eine Muttergesellschaft Finanzverbindlichkeiten einer Tochtergesellschaft, sei es durch Vertragsübernahme oder durch Beitritt als Solidarschuldnerin. Die Vertragsübernahme und der daraus folgende Schuldnerwechsel setzt die Zustimmung sämtlicher Gläubiger voraus. Dabei ist darauf aufzupassen, dass durch den Schuldnerwechsel die akzessorischen Sicherheiten nicht untergehen.

Die strukturelle Subordination ist ein geeignetes Mittel, eine Vor- bzw. Nachrangstellung zu erreichen, wenn ein Finanzinstrument an eine Vielzahl von Gläubigern ausgegeben wird und es faktisch nicht möglich ist, diese Gläubiger vertraglich in einen Intercreditor-Vertrag einzubinden. Dies gilt bspw. für die Gläubiger der von den beiden Lux-Gesellschaften ausgegebenen Anleihen. Um die Ansprüche der Gläubiger dieser Anleihen gegenüber den Banken, welche der BidCo den vorrangigen Akquisitionskredit gewährt haben, zu subordinieren, müssen die Anleihensgläubiger strukturell dadurch subordiniert werden, dass die Anleihen nicht von der BidCo, sondern von direkten und indirekten Muttergesellschaften der BidCo ausgegeben werden.

Werden die Mittel aus diesen Anleihen nicht über Eigenkapitaleinlagen an die BidCo weitergegeben, sondern über Aktionärsdarlehen, dann verlangen die Banken, welche der BidCo den Akquisitionskredit gewährt haben, dass diese Aktionärsdarlehen gegenüber der Bankfinanzierung vertraglich nachrangig gestellt werden.

\section{Vertragliche Rangordnung}

\section{a) Einleitung}

Ein zentrales, wenn nicht gar das zentralste Element eines Intercreditor-Vertrags ist die Regelung der Rangordnung verschiedener Gläubiger oder Gläu-

DIEM/JAHN, §40 N 10. 
bigergruppen untereinander. ${ }^{35}$ Vertraglich können Gläubiger untereinander vereinbaren, dass bestimmte Gläubiger ungeachtet der Fälligkeit ihrer Forderungen vor anderen Gläubigern befriedigt werden sollen. Dazu gehört bspw. die vertragliche Regelung der Mittelverwendung bei zwingenden vorzeitigen Rückzahlungen (Mandatory Prepayment) unter einem Senior- und einem Mezzanine-Kredit. Sollten unter beiden Verträgen die Voraussetzungen einer zwingenden vorzeitigen Rückzahlung gegeben sein, dann können sich die Mezzanine-Gläubiger vertraglich bereit erklären, dass ihre Forderungen erst bedient werden sollen, wenn die Forderungen der Senior-Gläubiger vollständig getilgt sind. ${ }^{36}$

Das Schweizer Recht ermöglicht verschiedene solcher vertraglichen Gestaltungsformen, die jeweils unterschiedliche Rechtswirkungen entfalten. Entsprechend ist wichtig zu verstehen, was jeweils genau mit "Subordination“ gemeint ist.

Nachfolgend sollen die folgenden drei Möglichkeiten dargestellt und miteinander verglichen werden: (i) Nachrangvereinbarung, (ii) einfache Rangrücktrittserklärung und (iii) Rangrücktritt im Sinne von Art. 725 Abs. 2 OR.

\section{b) Arten der vertraglichen Rangordnung}

aa) Nachrangvereinbarung

aaa) Parteien

Die Nachrangvereinbarung ist eine vertragliche Abrede zwischen mindestens zwei Gläubigern oder Gläubigergruppen ein und desselben Schuldners, wobei sich der nachrangige Gläubiger bereit erklärt, zugunsten des vorrangigen Gläubigers auf die Befriedigung seiner eigenen Forderung so lange zu verzichten, als die Forderungen des oder der vorrangigen Gläubiger nicht vollständig befriedigt sind.$^{37}$ Der nachrangige Gläubiger erklärt sich m.a.W. bereit, dass Leistungen aus Ansprüchen, die ihm aufgrund seiner nachrangigen Forderung zustehen, zuerst zur Befriedigung des vorrangigen Gläubigers verwendet werden.

\footnotetext{
35 DIEM/JAHN, $\$ 40$ N 22.

36 DIEM/JAHN, §40 N 14.

37 GlanZmanN, Rangrücktritt, 7.; KÄLIN, 54.
} 
Der Schuldner ist typischerweise ebenfalls Partei einer solchen Nachrangvereinbarung, wodurch der bilateralen Abrede zwischen dem nachrangigen Gläubiger und den vorrangigen Gläubigern eine gewisse Aussenwirkung verliehen werden kann.

\section{bbb) Rechtswirkung}

Die Nachrangvereinbarung ist in erster Linie ein Sicherungsgeschäft zwischen zwei Gläubigern oder Gläubigergruppen. Eine unmittelbare Sanierungswirkung hat eine Nachrangvereinbarung nicht. ${ }^{38}$

Sofern die Vereinbarung einzig bilateral zwischen dem nachrangigen Gläubiger und den vorrangigen Gläubigern geschlossen wird und der Schuldner nicht ebenfalls Partei der Vereinbarung ist, erschöpft sich die Wirkung darin, dass sich der nachrangige Gläubiger gegenüber den vorrangigen Gläubigern verpflichtet, Zahlungen, die er erhält, an die vorrangigen Gläubiger auszukehren, bis die Forderungen der vorrangigen Gläubiger befriedigt sind. Die Parteien sind frei zu vereinbaren, ob die Nachrangvereinbarung nur den Kreditoder Darlehensbetrag (Principal) an sich oder auch Zinsen, Gebühren und weitere Kosten erfassen soll. ${ }^{39}$

Im Konkurs des Schuldners würden die Forderungen des nachrangigen Gläubigers und der vorrangigen Gläubiger gleichauf (pari passu) in der dritten Konkursklasse kolloziert und die Gläubiger würden im gleichen Verhältnis eine Konkursdividende ausbezahlt erhalten. Der nachrangige Gläubiger wäre bei Erhalt der Konkursdividende - wie erwähnt - verpflichtet, die Mittel an die vorrangigen Gläubiger weiterzuleiten. Die rein bilaterale Nachrangvereinbarung würde gegenüber der schuldnerischen Gesellschaft keinerlei Aussenwirkung entfalten.

Tritt die schuldnerische Gesellschaft der Nachrangvereinbarung bei, so kann der Vereinbarung wie folgt Aussenwirkung verliehen werden: Erstens kann der nachrangige Gläubiger gegenüber dem Schuldner erklären, dass er seine Forderungen so lange stundet, bis die Forderungen der vorrangigen Gläubiger vollständig (oder bis zu einem vereinbarten Umfang) befriedigt sind. ${ }^{40}$ Die Stundung verhindert den Eintritt der Fälligkeit der nachrangigen Forderung, wodurch der nachrangige Gläubiger die Erfüllung dieser Forderungen bis zum Ablauf der Stundung rechtlich nicht einfordern kann.

\footnotetext{
38 KÄLIN, 55.

39 GLANZMANN, Rangrücktritt, 19.

40 GlanZMANN, Rangrücktritt, 19; KÄLIN, 55.
} 
Mit der Stundung seiner Forderung muss der nachrangige Gläubiger auch auf die Verrechnung seiner Forderung verzichten. Ein Verrechnungsverzicht ergibt sich sachlogisch bereits daraus, dass die Stundung den Eintritt der Fälligkeit aufschiebt und es dem nachrangigen Gläubiger somit während der Stundung an einer fälligen Verrechnungsforderung fehlt. ${ }^{41}$

Um den Sicherungszweck der Nachrangvereinbarung mit Stundungsabrede nicht zu vereiteln, muss sich die schuldnerische Gesellschaft verpflichten, ihrerseits die an sich erfüllbare, aber gestundete eigene Schuld nicht vor Fälligkeit freiwillig gegenüber dem nachrangigen Gläubiger zu erfüllen oder ihm gegenüber zur Verrechnung zu bringen. ${ }^{42}$ Da der Sicherungszweck der Nachrangvereinbarung darin besteht, dass ein Gläubiger zugunsten eines anderen Gläubigers oder einer Gläubigergruppe bei der Verteilung von Mitteln des Schuldners im Rang hinter den bevorzugten Gläubiger, resp. die bevorzugte Gläubigergruppe zurücktritt, muss auch ausgeschlossen werden, dass der nachrangige Gläubiger seinen Anspruch gegenüber dem Schuldner bspw. im Rahmen einer Verrechnungsliberierung verliert. ${ }^{43}$ Durch einen solchen Debt-Equity Swap würde den bevorzugten Gläubigern das erforderliche Sicherungs- oder Haftungssubstrat entzogen und könnte daher nicht mehr zur bevorzugten Befriedigung der vorrangigen Gläubiger herangezogen werden.

Da es sich bei der Nachrangvereinbarung um einen Vertrag zugunsten der vorrangigen Gläubiger handelt, muss den begünstigten Gläubigern ein Recht eingeräumt werden, im Fall einer vertragswidrigen Tilgung der nachrangigen Forderung die Rückzahlung des entsprechenden Betrags an die schuldnerische Gesellschaft zu verlangen. ${ }^{44}$

Eine zweite und sehr effektive Möglichkeit, der Nachrangvereinbarung gegenüber dem Schuldner Aussenwirkung zu verleihen, besteht darin, dass der nachrangige Gläubiger seine nachrangige Forderung an den vorrangigen Gläubiger bzw. die vorrangigen Gläubiger abtritt. ${ }^{45}$ Sollten mehrere Gläubiger vorrangig sein, so wird die Forderungen an einen Sicherheitenagenten (Security Agent) abgetreten, der typischerweise als indirekter Stellvertreter in eigenem Namen aber auf Rechnung der vorrangigen Gläubiger handelt.

\footnotetext{
41 BSK OR I-MÜller A., Art. 120 N 4 m.w.H.

42 GlanZMANN, Rangrücktritt, 19.

43 GlanZMANN, Rangrücktritt, 19.

44 GlanZMANN, Rangrücktritt, 19.

45 GlanZmanN, Rangrücktritt, 19.
} 
Durch die Sicherungsabtretung der nachrangigen Forderung kann sichergestellt werden, dass insbesondere im Konkurs der schuldnerischen Gesellschaft, wenn alle Forderungen gegenüber der konkursiten Gesellschaft mit Konkurseintritt fällig werden, der Nachrang dadurch beachtet wird, dass die schuldnerische Gesellschaft aufgrund der Abtretung ohnehin verpflichtet ist, an den vorrangigen Gläubiger zu leisten. Aufgrund der Sicherungsabrede, die mit der Abtretung einhergeht, ist der vorrangige Gläubiger im Konkurs der schuldnerischen Gesellschaft zwar berechtigt, die abgetretene Forderung zu kollozieren, er bleibt aber verpflichtet, einen allfälligen Überschuss dem nachrangigen Gläubiger herauszugeben. ${ }^{46}$

\section{bb) Einfache Rangrücktrittserklärung}

aaa) Parteien

Die einfache Rangrücktrittserklärung ist die Erklärung eines Gläubigers gegenüber der schuldnerischen Gesellschaft, seine Forderung im Falle eines Konkurses der schuldnerischen Gesellschaft im Rang hinter die Forderungen sämtlicher übriger Gläubiger der schuldnerischen Gesellschaft zurückzustellen. ${ }^{47}$

\section{bbb) Rechtswirkung}

Im Unterschied zur Nachrangvereinbarung zwischen einem nachrangigen Gläubiger und einem vorrangigen Gläubiger zeitigt die Rangrücktrittserklärung Wirkung gegenüber allen Gläubigern der schuldnerischen Gesellschaft. Dadurch verliert die Rangrücktrittserklärung den typischen Sicherungscharakter, welche die Nachrangvereinbarung im bilateralen Verhältnis zwischen zwei Gläubigern hat. Ein vorrangiger Gläubiger kann seinen Anteil an der Konkursdividende nicht mehr dadurch erhöhen, dass er den Anteil des nachrangigen Gläubigers exklusiv zugesprochen erhält.

Der einfache Rangrücktritt gilt als echter Vertrag zugunsten Dritter, und wie PETER BÖCKLI schwärmt „vielleicht sogar eines der schönsten Beispiele dieser Rechtsfigur" ${ }^{48}$ Dies hat zur Folge, dass der im Rang zurückgetretene Gläubiger den Rangrücktritt nicht mehr ohne Zustimmung der schuldnerischen Gesellschaft widerrufen kann. ${ }^{49}$ Weiter kann die schuldnerische Gesellschaft den

\footnotetext{
46 GlanZMANN, Rangrücktritt, 20.

47 BÖCKLI, §13 N 792.

48 BÖCKLI, §13 N 798.

49 GLANZMANN, Rangrücktritt, 11.
} 
im Rang zurückgetretenen Gläubiger nicht mehr vom Rangrücktritt entbinden, sobald die begünstigten Gläubiger im Sinne von Art. 112 Abs. 3 OR erklärt haben, dass sie von ihrem Recht bzw. von ihrem Vorrang Gebrauch machen wollen.

Durch ihre Erklärung treten die begünstigten Gläubiger der Rangrücktrittsvereinbarung zwischen dem nachrangigen Gläubiger und der schuldnerischen Gesellschaft bei, und sie erhalten einen einklagbaren Anspruch gegenüber dem im Rang zurückgetretenen Gläubiger. ${ }^{50}$ Die begünstigten, vorrangigen Gläubiger müssen den Rangrücktritt so gegen sich gelten lassen, wie er zwischen dem nachrangigen Gläubiger und der schuldnerischen Gesellschaft vereinbart wurde. Wurde der Rangrücktritt bspw. unter einer Bedingung oder zeitlich befristet abgeschlossen, so müssen die begünstigten Gläubiger diese Vertragsabreden auch gegen sich gelten lassen. ${ }^{51}$

Der Gläubiger der nachrangigen Forderung kann die Rangrücktrittserklärung bezüglich einer bereits bestehenden Forderung (nachträglicher Rangrücktritt) wie auch mit Bezug auf künftige Forderungen abgeben (ursprünglicher oder originärer Rangrücktritt). ${ }^{52}$

Denkbar ist, dass verschiedene Gläubiger oder Gläubigergruppen untereinander eine gestufte Rangordnung vorsehen.

cc) Rangrücktritt im Sinne von Art. 725 Abs. 2 OR

\section{aaa) Parteien}

Der Rangrücktritt im Sinne von Art. 725. Abs. 2 OR ist eine Vereinbarung zwischen einem Gläubiger und einer schuldnerischen Gesellschaft, wonach der nachrangige Gläubiger seine Forderung oder seine Forderungen gegenüber der schuldnerischen Gesellschaft bis zur Beseitigung einer Überschuldung stundet und im Fall des Konkurses der schuldnerischen Gesellschaft im Rang hinter sämtliche vorrangigen Gläubiger der Gesellschaft zurücktritt. ${ }^{53}$

\footnotetext{
50 BÖCKLI, §13 N 798.

51 GLANZMANN, Rangrücktritt, 11.

52 GLANZMANN, Rangrücktritt, 10.

53 BSK OR II-WÜSTINER, Art. 725 N 45 ff.; GLANZMAnN, Rangrücktritt, 11 ff.; KäLIN, 52 ff.; RHOdE, $75 \mathrm{ff}$.
} 


\section{bbb) Rechtswirkung}

Der Rangrücktritt im Sinne von Art. 725 Abs. 2 OR ist ein qualifizierter Rangrücktritt mit Stundung. ${ }^{54}$ Dieser Rangrücktritt ist kein Sicherungsgeschäft zugunsten eines Gläubigers oder verschiedener Gläubigergruppen, sondern ein aktienrechtliches Instrument, das es dem Verwaltungsrat einer überschuldeten Gesellschaft erlaubt, die Benachrichtigung des Konkursrichters zu unterlassen. ${ }^{55}$

Auf eine vertiefte Darstellung des qualifizierten Rangrücktritts mit Stundung nach Art. 725 Abs. 2 OR soll verzichtet und diesbezüglich auf die reichhaltige Spezialliteratur verwiesen werden. ${ }^{56}$

\section{Intercreditor-Verträge}

\section{Vertragsstrukturen}

Es gibt verschiedene Verträge, die Rechtsbeziehungen unter mehreren Gläubigern ein und desselben Schuldners regeln. Dabei ist zu unterscheiden, ob die Gläubiger gleich- oder verschiedenartige Forderungen haben. Übertragen auf das Beispiel einer Akquisitionsfinanzierung heisst das, dass zu unterscheiden ist, ob das Verhältnis zwischen Gläubigern unter ein und demselben Finanzierungsinstrument zu regeln ist oder ob die Gläubiger bzw. die Gläubigergruppen Forderungen unter verschiedenen Finanzierungsinstrumenten haben.

Haben mehrere Gläubiger Forderungen unter einem einzelnen Finanzierungsinstrument, dann regeln sie ihr Rechtsverhältnis typischerweise in einem Konsortial- oder Syndikatsvertrag. Haben Gläubiger dagegen Forderungen unter verschiedenen Finanzierungsinstrumenten, dann regeln sie ihre gegenseitigen Rechte und Pflichten in der Regel in einem Intercreditor-Vertrag.

Bei einem Konsortial- oder Syndikatsvertrag handelt es sich um eine vertraglich begründete Personenvereinigung, die den gemeinsamen Zweck verfolgt, einen Grosskredit zu gewähren, das Vorgehen gegenüber dem Kreditnehmer

\footnotetext{
54 BÖCKLI, §13 N $794 \mathrm{ff}$.

55 KäLIN, 52 f.; RHODE, 76 ff. m.w.H.

56 BSK OR II-WÜStiner, Art. 725 N 45 ff.; Glanzmann, Rangrücktritt, 11 ff.; KäLIN, 52 ff.; RHOdE, $75 \mathrm{ff}$.
} 
zu koordinieren und die Rückerstattung des Kredits sicherzustellen. ${ }^{57}$ Kreditkonsortien oder Syndikate werden von der herrschenden Lehre als einfache Gesellschaften im Sinne von Art. 530 OR qualifizert. ${ }^{58}$

Im Folgenden sollen typische Elemente von Intercreditor-Verträgen dargestellt werden.

\section{Parteien}

Parteien eines Intercreditor-Vertrags sind die verschiedenen Gläubiger bzw. die verschiedenen Gläubigergruppen, die einem gemeinsamen Schuldner Fremdkapital gewährt haben, sei es unter einem einheitlichen oder unter verschiedenartigen Finanzierungsinstrumenten. ${ }^{59}$ Ebenfalls Partei des Vertrags sind die Agenten, die als Beauftragte der verschiedenen Gläubigergruppen die Gläubiger gegenüber dem Schuldner vertreten. ${ }^{60}$

Die schuldnerische Gesellschaft bzw. die schuldnerischen Gesellschaften sind ebenfalls Partei des Intercreditor-Vertrags. Schuldnerische Gesellschaften können die Gesellschaften sein, denen in ihrer Funktion als Emittentin unter einer Anleihe oder als Kredit- oder Darlehensnehmerin tatsächlich Kapital zugeflossen ist, sowie weitere Gruppengesellschaften, die lediglich Personalsicherheiten in Form von typischerweise Garantien oder seltener Bürgschaften abgegeben haben.

Sollten die Finanzierungen mit Realsicherheiten besichert sein, dann sind einerseits die Sichherheitengeber Partei des Intercreditor-Vertrags sowie andererseits die Sicherheitenagenten (Security Agent), denen die Sicherheiten eingeräumt wurden. Die Sicherheitenagenten handeln mit Bezug auf akzessorische Sicherheiten als direkte Stellvertreter im Namen und auf Rechnung der besicherten Gläubiger und mit Bezug auf nicht akzessorische Sicherheiten in der Regel als indirekte Stellvertreter in eigenem Namen und auf Rechnung der besicherten Gläubiger. ${ }^{61}$

Weitere Parteien können unter Umständen Hedging-Gegenparteien der Gläubiger sein, der Sponsor oder auch die Verkäuferpartei, wenn sie der BidCo zum Zweck der Kaufpreisfinanzierung ein sog. Verkäuferdarlehen (Vendor Loan) gewährt hat.

\footnotetext{
57 MALACRIDA, 192 ff.; MAURENBRECHER/FRICK, 76.

58 MALACRIDA, 199 f.; MAURENBRECHER/Frick, $77 \mathrm{f}$.

59 DIEM/JAHN, $440 \mathrm{~N} 19$.

60 DIEM/JAHN, $§ 32 \mathrm{~N} 2$.

61 MAURENBRECHER/Frick, $62 \mathrm{f}$.
} 
Die Eigenkapitalinvestoren sind häufig nicht Partei eines Intercreditor-Vertrags. Der Nachrang ihrer Forderungen unter Aktionärsdarlehen wird typischerweise in einer separaten Rangrücktrittsvereinbarung (Subordination Agreement) geregelt. ${ }^{62}$

\section{Regelungsgegenstände}

Im Nachgang sollen einige typische Regelungsgegenstände in IntercreditorVerträgen dargestellt werden. Die Vertragsklauseln, die als Beispiele beigezogen werden, sind dem LMA Intercreditor Agreement for Leveraged Acquisition Finance Transactions (Senior/Mezzanine) in der Version vom 20. März 2020 entnommen.

\section{a) Rangordnung}

Bezüglich vertraglicher Regelung der Rangordnung zwischen verschiedenen Gläubigern bzw. Gläubigergruppen ein und desselben Schuldners sei auf die Ausführungen oben unter Ziffer IV.4 verwiesen.

\section{b) Zahlungen an nachrangige Gläubiger}

Der Vorrang der Senior-Gläubiger gegenüber den nachrangigen Gläubigern zeigt sich auch darin, dass die nachrangigen Gläubiger bis zur vollständigen Tilgung der vorrangigen Gläubiger grundsätzlich keine Zahlungen des Schuldners annehmen dürfen bzw. der Schuldner Zahlungen an nachrangige Gläubiger auch nur in beschränktem Umfang leisten darf. ${ }^{63}$ Zulässig sind in der Regel einzig Zinszahlungen sowie Zahlung gewisser Kosten oder Steuern.

Kommt ein Schuldner gegenüber den Senior-Gläubigern in Zahlungsverzug oder liegt sonst ein Verzugsfall vor, so sind die Senior-Gläubiger berechtigt, die ansonsten zulässigen Zahlungen an nachrangige Gläubiger vorübergehend zu untersagen. Zu diesem Zweck sprechen sie einen Zahlungsstopp aus (Payment Stop Notice). Liegt ein Zahlungsverzug gegenüber den Senior-Gläubigern

62 DIEM/JAHN, §40 N 20.

63 Vgl. LMA Intercreditor Agreement (Senior/Mezzanine), Clause 5.1 (Restriction on Payment: Mezzanine Liabilities): „The Debtors shall not and shall procure that no other member of the Group will, make any Payments of the Mezzanine Liabilities at any time unless: (a) that Payment is permitted under Clause 5.2 (Permitted Payments: Mezzanine Liabilities); or (b) the taking or receipt of that Payment is permitted under paragraph [...] of Clause [...] (Permitted Enforcement: Mezzanine Creditors)“. 
vor, so kann der Zahlungsstopp unbefristet ausgesprochen werden. Liegt ein anderer Verzugsfall vor, so gilt der Zahlungsstopp zeitlich befristet, bspw. für 120 Tage. $^{64}$

\section{c) Zusätzliche Sicherheiten zugunsten nachrangiger Gläubiger}

Den nachrangigen Gläubigern dürfen Sicherheiten oder zusätzliche Sicherheiten nur bestellt werden, wenn die Mehrheit der vorrangigen Gläubiger eine solche Sicherheitenbestellung genehmigt. ${ }^{65}$ Die Genehmigung dürfte dann begünstigt werden, wenn die vorrangigen Gläubiger mindestens gleichrangig von der Sicherheiten profitieren (pari passu secured).

\section{d) Suspendierung von Rechten nachrangiger Gläubiger}

Solange die Forderungen der vorrangigen Gläubiger nicht befriedigt sind, werden verschiedene Rechte der nachrangigen Gläubiger suspendiert. Dazu

64 Vgl. LMA Intercreditor Agreement (Senior/Mezzanine), Clause 5.3 (Issue of Mezzanine Payment Stop Notice): „(a) A Mezzanine Payment Stop Notice is ,outstanding during the period from the date on which, following the occurrence of a Mezzanine Payment Stop Event, the Security Agent (acting on the instructions of the Majority Senior Creditors) issues a notice (a ,Mezzanine Payment Stop Notice) to the Mezzanine Agent (with a copy to the Parent) advising that the Mezzanine Payment Stop Event has occurred and is continuing and suspending Payments of the Mezzanine Liabilities until the first to occur of: (i) the date which is [...] day after the date of issue of the Mezzanine Payment Stop Notice; (ii) if a Mezzanine Standstill Period commences after the issue of a Mezzanine Payment Stop Notice, the date on which that Mezzanine Standstill Period expires; (iii) the date on which the Mezzanine Payment Stop Event in respect of which that Mezzanine Payment Stop Notice was issued is no longer continuing; (iv) the date on which the Security Agent (acting on the instructions of the Majority Senior Creditors) cancels that Mezzanine Payment Stop Notice by notice to the Mezzanine Agent (with a copy to the Parent); and (v) the Senior Discharge Date."

65 Vgl. LMA Intercreditor Agreement (Senior/Mezzanine), Clause 5.10 (Security: Mezzanine Creditors): „At any time prior to the Senior Discharge Date, the Mezzanine Creditors may not take, accept or receive the benefit of any Security, guarantee, indemnity or other assurance against loss from (or over the assets of or over shares in) any member of the Group in respect of the Mezzanine Liabilities other than: (a) the Common Transaction Security; (b) any guarantee, indemnity or other assurance against loss contained in: (i) the original form of Mezzanine Facility Agreement; (ii) this Agreement; (iii) the original form of Mandate Letter (as defined in the Mezzanine Facility Agreement); or (iv) any Common Assurance; and (c) as otherwise contemplated by Clause [...] (Security: Senior Facility Creditors), unless the prior consent of the Majority Senior Creditors is obtained." 
gehören bspw. die Kündigung nachrangiger Finanzierungen, die Verrechnung, die Verwertung von Sicherheiten ${ }^{66}$, der Abschluss eines Vergleichs mit dem Schuldner oder die Stellung eines Konkursantrags. ${ }^{67}$

Damit die nachrangigen Gläubiger in der Ausübung ihrer Rechte nicht übermässig blockiert werden, gilt Folgendes: Liegt bspw. ein Kündigungsgrund vor, der die nachrangigen Gläubiger zur Kündigung ihrer Kredite berechtigen würde, so können sie die vorrangigen Gläubiger dadurch unter Zugzwang setzen, dass sie ihnen ein schriftliches Verwertungsbegehren (Mezzanine Enforcement Notice) unterbreiten. Nach Abgabe dieser Erklärung beginnt eine Stillhalteperiode zu laufen (Mezzanine Standstill Period), während der die nachrangigen Gläubiger keine Verwertungsmassnahmen ergreifen dürfen. Die Idee ist aber, dass die vorrangigen Gläubiger diese Frist nutzen, um ihrerseits Verwertungsschritte zu unternehmen, ohne dabei von den nachrangigen Gläubigern gestört zu werden. Besteht der Kündigungsgrund nach Ablauf der Stillhalteperiode noch fort, so werden die nachrangigen Gläubiger ihrerseits berechtigt, nun eigenständige Verwertungsschritte zu unternehmen. ${ }^{68}$

\section{e) Verwertung von Sicherheiten}

Wurden Sicherheiten zur Besicherung der vorrangigen Forderungen sowie der nachrangigen Forderungen bestellt, so wird der Sicherheitenagent (Security Agent) diese Sicherheiten grundsätzlich nur auf Anweisung der vorrangigen Gläubiger verwerten ${ }^{69}$ Sobald die vorrangigen Gläubiger befriedigt sind, geht das Instruktionsrecht auf die nachrangigen Gläubiger über. ${ }^{70}$

Vgl. LMA Intercreditor Agreement (Senior/Mezzanine), Clause 5.11 (Restriction on Enforcement: Mezzanine Creditors): „Subject to Clause 5.12 (Permitted Enforcement: Mezzanine Creditors), no Mezzanine Creditor shall be entitled to take any Enforcement Action in respect of any of the Mezzanine Liabilities prior to the Senior Discharge Date." DIEM/JAHN, §40 N 28. Vgl. LMA Intercreditor Agreement (Senior/Mezzanine), Clause 5.12 (Permitted Enforcement: Mezzanine Creditor).

Vgl. LMA Intercreditor Agreement (Senior/Mezzanine), Clause 12.2 (Enforcement Instructions): „(a) the Security Agent may refrain from enforcing the Transaction Security unless instructed otherwise by: (i) the Instructing Group; or [...].“

Vgl. LMA Intercreditor Agreement (Senior/Mezzanine), Clause 1.1 (Definitions): „Instructing Group" means at any time: (a) prior to the Senior Discharge Date, the Majority Senior Creditors; and (b) on or after the Senior Discharge Date, the Majority Mezzanine Lenders." 
Der Sicherheitenagent verteilt den Verwertungserlös nach einer vertraglich vorgegebenen Reihenfolge (Waterfall). ${ }^{71}$ Zuerst behält der Sicherheitenagent den notwendigen Betrag zur Deckung seiner eigenen Gebühren und Kosten ein. Sodann werden die Forderungen der vorrangigen Gläubiger und allenfalls der Hedging-Gegenparteien bedient und anschliessend werden die Forderungen der nachrangigen Gläubiger befriedigt. Die Zahlungen an die vorrangigen Gläubiger bzw. die nachrangigen Gläubiger werden jeweils über deren Agenten ausbezahlt. Letztlich können weitere Gläubiger der schuldnerischen Gesellschaft bedient werden wie bspw. die Verkäufer unter allfälligen Verkäuferdarlehen oder Aktionäre unter allfälligen Aktionärsdarlehen.

\section{g) Vertragsänderungen}

Intercreditor-Verträge versuchen die Rechte und Risiken zwischen verschiedenen Gläubigergruppen eines Schuldners ausgewogen zu allozieren. Dazu gehört, dass die einzelnen Gläubiger oder Gläubigergruppen nach Abschluss ihrer Finanzierungen und Abschluss ihrer jeweiligen Finanzierungsverträge die Risiken, die mit einer Finanzierung einhergehen, nicht zu Ungunsten der anderen Gläubigergruppen verändern.

Die Pflicht, die zugrundeliegenden Finanzierungsverträge nicht zulasten anderer Gläubiger zu verändern, wird den vorrangigen wie auch den nachrangigen Gläubigern auferlegt. So wird bspw. den Senior-Kreditgebern wie den Mezzanine-Kreditgebern in einem Intercreditor-Vertrag untersagt, die Kreditbeträge oder die Zinsmargen unter ihren jeweiligen Kreditverträgen zu

71 Vgl. LMA Intercreditor Agreement (Senior/Mezzanine), Clause 18.1 (Order of application). 
erhöhen bzw. nicht über einen im Voraus vereinbarten Freibetrag hinaus zu erhöhen, sofern dazu nicht die Zustimmung der Mehrheit der Gläubiger aus den anderen Gläubigergruppen vorliegt. ${ }^{72}$

Vertraglich wird insbesondere nachrangigen Gläubigern nicht nur untersagt, ihre Forderungen gegenüber der schuldnerischen Gesellschaft zu erhöhen, sondern es kann ihnen auch untersagt werden, Forderungen zu erlassen. Eine solche Einschränkung macht dann Sinn, wenn die Forderungen den vorrangigen Gläubigern zu Sicherungszwecken abgetreten sind und die vorrangigen Gläubiger im Konkurs des Schuldners das Recht hätten, auch diese nachrangigen Forderungen geltend zu machen. ${ }^{73}$

\section{h) Vorrangstellung des Intercreditor-Vertrags (Override)}

Bei der Finanzierung einer Unternehmensübernahme mittels verschiedener Finanzierungsinstrumente ist der Intercreditor-Vertrag das zentrale Vertragsdokument, quasi das Bindeglied zwischen den einzelnen Finanzierungsverträgen. Um die Einheitlichkeit der verschiedenen Regelungen zu erreichen und Widersprüche zwischen den verschiedenen Finanzierungsverträgen zu vermeiden, enthält der Intercreditor-Vertrag regelmässig eine Bestimmung, wonach die Regelungen im Intercreditor-Vertrag allfälligen anderen, widersprüchlichen Bestimmungen in vom Intercreditor-Vertrag erfassten Finanzierungsverträgen vorgeht. ${ }^{74}$ Eine solche Vorrangbestimmung ist sinnvoll und entspricht dem Verständnis, dass die verschiedenen Verträge letztlich unter-

72 Vgl. LMA Intercreditor Agreement (Senior/Mezzanine), Clause 3.3 (Restrictions on amendment and waivers: Senior Facility Liabilites): „The Senior Facility Creditors may not amend or waive the terms of the Senior Finance Documents if the amendment or waiver is, in relation to the original form of the Senior Finance Documents an amendment or waiver which: (a) constitutes a Senior Principal Increase the amount of which exceeds the Senior Headroom at that time; (b) constitutes an increase in the applicable Margin or the inclusion of an additional margin, relating to the Senior Facilities other than such an increase or inclusion which is: (i) contemplated by the original form of the Senior Finance Document; (ii) not so contemplated but which is made pursuant to an agreement with the relevant Debtors prior to completion of primary syndication of the Senior Facilities and is intended to enhance the prospects of a successful syndication of the Senior Facilities; or (iii) not otherwise permitted pursuant to paragraphs (i) or (ii) above and [the effect of does not cause the Senior Yield Headroom at that time to be exceeded $] /[\ldots] ;[\ldots]$; unless the prior consent of the Majority Mezzanine Lenders is obtained." DIEM/JAHN, §40 N 23.

74 Vgl. LMA Intercreditor Agreement (Senior/Mezzanine), Clause 28.15 (Override): „Unless expressly stated otherwise in this Agreement, this Agreement overrides anything in the Debt Documents to the contrary." 
einander ein in sich stimmiges Vertragsnetz bilden sollen. Vorsicht ist einzig geboten, wenn Bestimmungen in einem Intercreditor-Vertrag, der allenfalls einem anderen Recht als Schweizer Recht untersteht, Vorrang bspw. gegenüber Sicherheitenverträgen unter Schweizer Recht geniessen soll. Um beispielsweise die Einhaltung des gemäss Schweizer Pfandrechts zwingenden Akzessorietätsprinzips nicht zu gefährden, empfiehlt es sich, im IntercreditorVertrag explizit zu regeln, dass der Sicherheitenagent mit Bezug auf akzessorische Sicherheiten unter Schweizer Recht jeweils als direkter Stellvertreter, d.h. im Namen und auf Rechnung der pfandgesicherten Gläubiger handeln soll.

\section{Fazit}

Intercreditor-Verhältnisse und Intercreditor-Verträge haben eine untergeordnete Bedeutung, solange ein finanziertes Unternehmen finanziell aufrechtstehend ist. Solange ein Unternehmen alle gegen sich gerichteten Forderungen zeitgerecht erfüllen kann und seine finanziellen Aussichten positiv sind, ist die Regelung der Rangfolge unter den Gläubigern wenig relevant. Wenn sich jedoch die finanzielle Situation eines Unternehmens verschlechtert, dann wird die Frage zentral, welcher Gläubiger zuerst befriedigt wird resp. in welcher Reihenfolge die vorhandenen finanziellen Mittel des Unternehmens den Gläubigern zugutekommen sollen.

Die Frage nach der Rangfolge der verschiedenen Gläubiger oder Gläubigergruppen eines Unternehmens gewinnt zusätzlich an Bedeutung, wenn diese dem Unternehmen unter verschiedenen Finanzierungsinstrumenten Kapital zur Verfügung gestellt haben und das mit diesen Instrumenten einhergehende Gegenpartei- und Ausfallrisiko unterschiedlich gross war und unterschiedlich entschädigt wurde.

Dass sich Unternehmen über verschiedene Finanzierungsinstrumente finanzieren, kommt vor allem bei grösseren Akquisitionsfinanzierungen häufig vor. Entsprechend gehören Intercreditor-Verträge mittlerweile standardmässig zum Vertragswerk einer solchen Finanzierung. Tatsächlich bildet der Intercreditor-Vertrag das zentrale Vertragsdokument, quasi das Bindeglied, zwischen den einzelnen Finanzierungsinstrumenten und Finanzierungsverträgen.

Dass der Intercreditor-Vertrag in der Schweizer Rechtslehre bislang kaum Beachtung gefunden hat, mag daran liegen, dass er bei grösseren Akquisitionsfinanzierungen häufig nicht unter Schweizer Recht steht, sondern typischerweise unter Englischem Recht. Nicht zu erstaunen mag daher auch, dass die 
Loan Market Association mittlerweile sechs verschiede Standard Intercreditor Agreements bereithält und diese regelmässig aktuellen Marktentwicklungen anpasst.

Mit dem im Schweizer Markt beobachtbaren Trend, dass insbesondere auch grössere Finanzierungen vermehrt dem Schweizer Recht unterstellt werden, ist es meines Erachtens nur eine Frage der Zeit, bis auch Intercreditor-Verträge vermehrt unter Schweizer Recht gestellt werden. Dieser Trend ist zu begrüssen.

Begrüssenswert ist auch, dass sich Kapitalgeber, die eine Unternehmensübernahme finanzieren, vermehrt mit ihren Rechten im Fall der Insolvenz der schuldnerischen Gesellschaft befassen; und zwar nicht nur mit ihren Rechten gegenüber dieser Gesellschaft, sondern auch mit ihren Rechten gegenüber den anderen Gläubigern dieser Gesellschaft. Für den Insolvenzfall gilt es, gerüstet zu sein, und daher ist das Verständnis von Intercreditor-Verhältnissen und die Gestaltung von Intercreditor-Verträgen essentiell.

\section{Literatur}

Baird G. Douglas/Gertner Robert H./Picker Randal C., Game Theory and the Law, Cambridge, Massachusetts and London 1994.

Basler Kommentar, Obligationenrecht I, Art. 1-529 OR, Hrsg.: Widmer Lüchinger Corinne/ Oser David, 7. A., Basel 2020 (zit. BSK OR I-BEARBEITER).

Basler Kommentar, Bundesgesetz über Schuldbetreibung und Konkurs II, Art. 159-352 SchKG, Art. 1-47 GSchG, Art. 51-58 AVIG, in: Staehelin Adrian/Bauer Thomas/Staehelin Daniel (Hrsg.), 2. A., Basel 2010 (zit. BSK SchKG II-BEARBEITER).

Basler Kommentar, Zivilgesetzbuch I, Art. 1-456 ZGB, Hrsg: Geiser Thomas/Fountoulakis Christina, 6. A., Basel 2018 (zit. BSK ZGB I-BEARBEITER).

BÖCKLi PETER, Schweizer Aktienrecht, 4. A., Zürich/Basel/Genf 2009.

BösCH RENÉ, Hybride Finanzierungsinstrumente, in: Reutter/Werlen (Hrsg.), Kapitalmarkttransaktionen III, Zürich/Basel/Genf 2008, 39 ff.

DiEM ANDREAS/JAHN CHRISTIAN H., Akquisitionsfinanzierungen - Kredite für Unternehmenskäufe, 4. A., München 2019.

FRICK JÜRG, Private Equity im Schweizer Recht, Diss. Zürich 2009.

Gauch Peter/Schluep Walter R./Schmid JÖRG/EMmenegGer SuSAN, Schweizerisches Obligationenrecht Allgemeiner Teil, 10. A., Zürich 2014.

GLANZMANN LUKAS, Der Darlehensvertrag mit einer Aktiengesellschaft aus gesellschaftsrechtlicher Sicht, Diss. Bern/Stuttgart/Wien 1996 (zit. GLANZMANN, Darlehensvertrag).

GLANZMANN LUKAS, Rangrücktritt oder Nachrangvereinbarung? GesKR 1/2007, 6 ff. (zit. GLANZMANN, Rangrücktritt). 
Hold MichaEL, Das kapitalersetzende Darlehen im Schweizer Aktien- und Konkursrecht, Diss. Bern/Stuttgart/Wien 2000.

KÄLIN OLIVER, Die Sanierung der Aktiengesellschaft, Zürich/Basel/Genf 2016.

Kren KostKiewicz Jolanta, Schuldbetreibungs- und Konkursrecht, Zürich/Basel/Genf 2012.

LANZ RudOLF, Kapitalverlust, Überschuldung und Sanierungsvereinbarung, Diss. Zürich 1985.

MALACRIDA RALPH, Der Konsortialvertrag, in: Reutter/Werlen (Hrsg.), Kapitalmarkttransaktionen III, Zürich/Basel/Genf 2008, 39 ff.

MAURENBRECHER BENEDIKT/FrICK JÜRG, Konsortialkredite, in: Emmenegger (Hrsg.), SBT 2010 Schweizerische Bankrechtstagung, Kreditrecht, Bern 2010, $47 \mathrm{ff}$.

MEYER TOBIAS, Gläubigerschutz durch Kapitalschutz - eine ökonomische und rechtsvergleichende Untersuchung der Schweizer Kapitalschutzvorschriften unter Berücksichtigung des Entwurfs zur Revision des Aktienrechts, Diss. Zürich 2009.

MÜlLER Oliver, Mezzanine Finance - Neue Perspektiven in der Unternehmensfinanzierung, Diss. St.Gallen 2003, (SECA Bd. 1).

Myers StewART C., The Capital Structure Puzzle, in: Journal of Finance 1984, 575 ff.

REUl Florian, Die Behandlung von Intercreditor Agreements in der Insolvenz, Diss. Leipzig 2015.

Reutter Thomas U./Weber Annette, Wandelanleihen, in: Reutter/Werlen (Hrsg.), Kapitalmarkt - Recht und Transaktionen XIII, Zürich/Basel/Genf 2019, $127 \mathrm{ff}$.

RHODE ThOmAs, Der Rangrücktritt - ein Tour d'Horizon, in: Sprecher (Hrsg.), Sanierung und Insolvenz von Unternehmen X - die aktienrechtliche Sanierung, Zürich/Basel/Genf 2020, $75 \mathrm{ff}$.

RIHM THOMAS, Nachrangige Schuldverpflichtungen, Diss. Zürich 1992.

Rотн JÜRG, Sanierungsdarlehen, Nachrang - Gleichrang - Vorrang, Diss. Basel 2009.

RUSCH ARNOLD, Interzession im Interesse des Aktionärs - Sicherheitenbestellung für Verbindlichkeiten von Mutter- und Schwestergesellschaften in der Schweiz, Diss. Zürich 2004

VON GREYERZ CHRISTOPH, Kapitalersetzende Darlehen, in: Böckli et al. (Hrsg.), Festschrift für Frank Vischer zum 60. Geburtstag, Zürich 1983, 547 ff.

\section{Loan Market Association (LMA) Vertragsvorlagen}

- Intercreditor Agreement for Leveraged Acquisition Finance Transactions (Super Senior/ Senior), Loan Market Association (LMA), 20 March 2020 (zit. LMA Intercreditor Agreement (Super Senior/Senior), Clause [-]).

- Intercreditor Agreement for Leveraged Acquisition Finance Transactions (Senior/Mezzanine), Loan Market Association (LMA), 20 March 2020 (zit. LMA Intercreditor Agreement (Senior/Mezzanine), Clause [-]).

- Intercreditor Agreement for Leveraged Acquisition Finance Transactions (Super Senior Revolving Facility/Senior Secured Notes), Loan Market Association (LMA), 20 March 2020 (zit. LMA Intercreditor Agreement (SSRCF/SSN), Clause [-]). 
- Intercreditor Agreement for Leveraged Acquisition Finance Transactions (Super Senior Revolving Facility/Senior Secured Notes/High Yield Notes), Loan Market Association (LMA), 20 March 2020 (zit. LMA Intercreditor Agreement (SSRCF/SSN/HYN), Clause [-]).

- Intercreditor Agreement for Real Estate Finance Transactions (Senior/Mezzanine), Loan Market Association (LMA), 20 March 2020 (zit. LMA Intercreditor Agreement Real Estate (Senior/Mezzanine), Clause [-]).

- Intercreditor Agreement for Real Estate Finance Transactions (Senior/Mezzanine - Contractual Subordination Only), Loan Market Association (LMA), 20 March 2020 (zit. LMA Intercreditor Agreement Real Estate (Senior/Mezzanine - Contractual Subordination), Clause [-]). 



\title{
Zuletzt erschienene Bände bei EIZ Publishing, Zürich
}

\author{
Band 201 Challenges, risks and threats for security in Europe \\ 11th Network Europe Conference, Warsaw, 19th-22nd May 2019 \\ ANDREAS KelLERHALS / TOBias BAUMGARTNER (Hrsg.), mit Beiträgen von Viorel \\ Cibotaru, Attila Vincze, Przemyslaw Saganek, Jelena Ceranic, Aleksei V. \\ Dolzhikov, Alena F. Douhan, Darina Dvornichenko, Vadym Barskyy, Itay \\ Fischhendler, Verena Murschetz, Jürgen Scheffran, Tobias Baumgartner, \\ 2019 - CHF 49.90.-
}

\section{Band $202 \quad$ Elftes Zürcher Präventionsforum \\ Neue Technologien im Dienste der Prävention: Möglichkeiten - Risiken \\ CHRISTIAN SCHWARZENEGGER / ROLF NÄGELI (Hrsg.), mit Beiträgen von Ulf Blanke, Ladina Cavelti, Ulrich Schimpel, Jasmine Stössel, Thomas Wenk, Bettina Zahnd, 2020 - CHF 49.90.-}

Band 203 Jahrbuch Wirtschaftsrecht Schweiz - EU

Überblick und Kommentar 2019/2020

ANDREAS Kellerhals / Tobias BaUmgartner (Hrsg.), mit Beiträgen von Tobias Baumgartner, Mathis Berger, Alexander Brunner, Theodor Bühler, Balthasar Dengler, Jana Fischer, Alfred Früh, Thomas Geiser, Pascal Grolimund, Stefan Härtner, Ulrike I. Heinrich, Isabel Höhener, Samuel Jost, Brigitta Kratz, David Mamane, Laura Manz, Michael Mayer, Urs Meier, Peter Rechsteiner, Antoine Schnegg, René Schreiber, Kurt Sieht, Stefan Sulzer, Wesselina Uebe, 2020 - CHF 49.90.-

\section{Ausserdem erschienen:}

Schweiz - Europäische Union

Grundlagen, Bilaterale Abkommen, Autonomer Nachvollzug MATTHIAS OESCH, 2020 - CHF 44.90.- 
Der vorliegende Tagungsband «Kapitalmarkt - Recht und Transaktionen» fokussiert wie immer auf aktuelle Entwicklungen im Bereich Finanz- und Kapitalmarktrecht unter besonderer Berücksichtigung von Transaktionen. Das Jahr 2019 war geprägt von einem stark wachsenden Bewusstsein für soziale und ökologische Themen, das auch vor Investoren nicht Halt gemacht hat. Eine wichtige Rolle spielten zudem der sich beschleunigende technologische Fortschritt und das sich anbahnende Ende des LIBOR. Entsprechend liegt der von den Herausgebern gesetzte Schwerpunkt auf Corporate Social Responsibility, der LIBOR-Ablösung und den zivil- und finanzmarktrechtlichen Aspekten der DLT-Vorlage des Bundesrates im Bereich Blockchain. Daneben erhalten auch traditionelle Themen wie Rechtsfragen im Zusammenhang mit Börsengängen und Analyst Reports Raum in diesem Band.

Mit Beiträgen von:

Marion Bähler

Christina Del Vecchio

Dr. Olivier Favre

Dr. Jürg Frick

Arie Gerszt

Dr. Sonja Maire

Dr. Alex Nikitine

Dr. Thomas U. Reutter

Annette Weber 